Editora Poisson

Ciência e Tecnologia dos Alimentos Volume 10

1a Edição

Belo Horizonte

Poisson

2021 
Editor Chefe: Dr. Darly Fernando Andrade

\section{Conselho Editorial}

Dr. Antônio Artur de Souza - Universidade Federal de Minas Gerais Msc. Davilson Eduardo Andrade

Dra. Elizângela de Jesus Oliveira - Universidade Federal do Amazonas

Msc. Fabiane dos Santos

Dr. José Eduardo Ferreira Lopes - Universidade Federal de Uberlândia

Dr. Otaviano Francisco Neves - Pontifícia Universidade Católica de Minas Gerais

Dr. Luiz Cláudio de Lima - Universidade FUMEC

Dr. Nelson Ferreira Filho - Faculdades Kennedy

Msc. Valdiney Alves de Oliveira - Universidade Federal de Uberlândia

Dados Internacionais de Catalogação na Publicação (CIP)

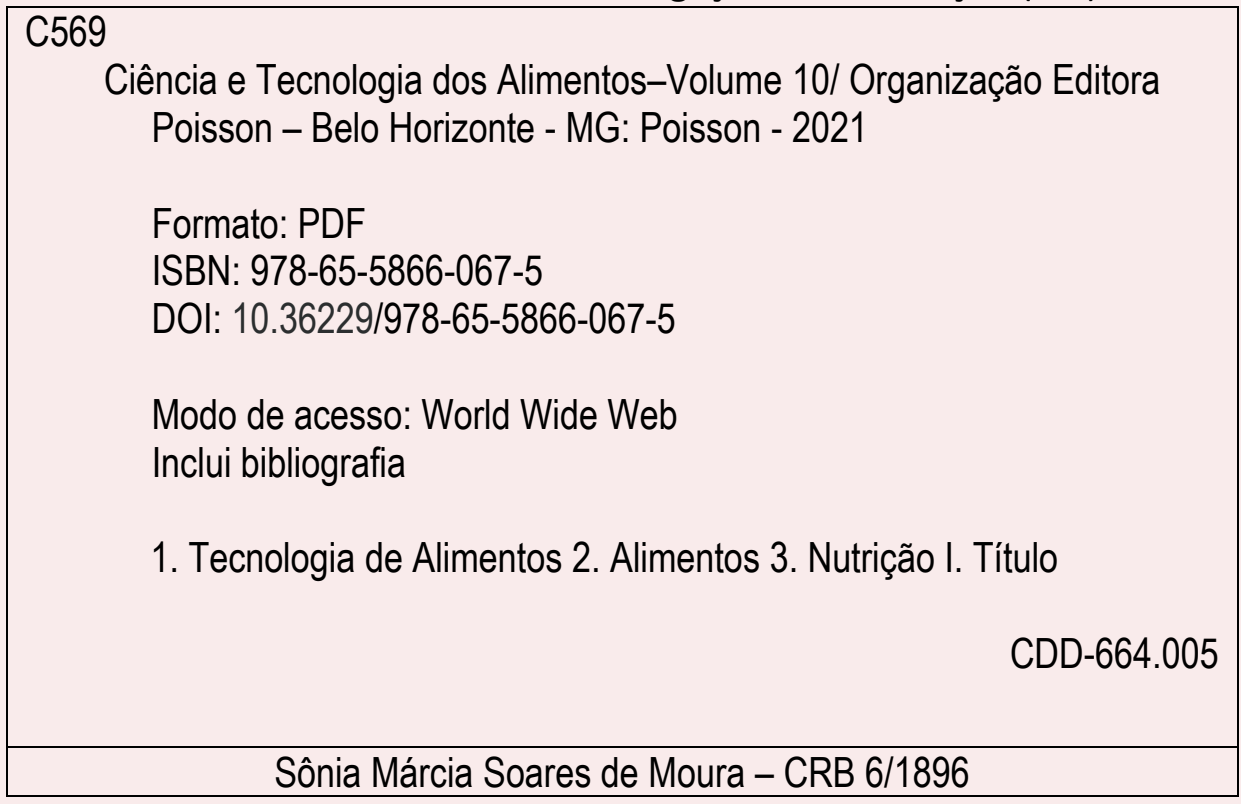

O conteúdo dos artigos e seus dados em sua forma correção e confiabilidade são de responsabilidade exclusiva dos seus respectivos autores.

www.poisson.com.br

contato@poisson.com.br 


\section{SUMÁRIO}

Capítulo 1: Aplicação das ferramentas de gestão da segurança de alimentos na merenda escolar: Estudo de caso 08

Fernanda Carla Henrique-Bana, Viviane Lopes Leite da Costa, Carina Moro Benis, Rebeca Priscila Flora Catarino, Saulo Fabiano Amâncio-Vieira, Maria Tereza Paschoal de Moraes, Vera Lucia Tieko Suguihiro, Wilma Aparecida Spinosa

DOI: 10.36229/978-65-5866-067-5.CAP.01

Capítulo 2: Avaliação da adequação da merenda escolar de um Centro Municipal de Educação Infantil do Alto Paranaíba-MG

Rafaela Alexia Ribeiro, Meire de Oliveira Barbosa

DOI: $10.36229 / 978-65-5866-067-5 . C A P .02$

Capítulo 3: Análise qualitativa da alimentação escolar de uma unidade de educação infantil. 20

Kellen Schaaff Souto, Carla Cristina Bauermann Brasil, Susana Berleze de Pelegrini

DOI: 10.36229/978-65-5866-067-5.CAP.03

Capítulo 4: Avaliação da atividade antimicrobiana de peptídeos produzidos por Bacillus amyloliquefaciens $\mathrm{P} 5$ e nanoencapsulação visando à inibição de bactérias patogênicas de alimentos.

Vinícius dos Santos Ribeiro, Lilian Raquel Hickert, Lúcia Allembrandt da Silva Ries, Patricia da Silva Malheiros, Karla Joseane Perez

DOI: 10.36229/978-65-5866-067-5.CAP.04

Capítulo 5: Eficácia microbiana e parasitária de sanitizantes à base de cloro e ácido acético em alface (Lactuca Sativa L.)......

Eveline Ferreira Soares, Juliana de Mello Silva, Vilmar Antônio Boff, Gerônimo Rodrigues Prado

DOI: 10.36229/978-65-5866-067-5.CAP.05

Capítulo 6: Avaliação da atividade de antimicrobianos em algodão e poliéster 40

Sabrina Cremonini, Creciana Maria Endres, Crivian Pelisser, Andressa Barella de Freitas, Josiane Betat da Silva, Elisa Sonza

DoI: 10.36229/978-65-5866-067-5.CAP.06 


\section{SUMÁRIO}

Capítulo 7: Avaliação da atividade antibacteriana de óleo essencial de pimenta rosa e sua aplicação biofilme de colágeno. 45

Felipe Ozorio Giacomelli, Suslin Raatz Thiel, Andrine Menna da Fontoura, Mari Silvia Rodrigues de Oliveira, Rosa Cristina Prestes Dornelles

DOI: 10.36229/978-65-5866-067-5.CAP.07

Capítulo 8: Aplicação de aditivo antimicrobiano para embalagens de queijo parmesão ralado 49

Letícia Santa Catarina, Rita de Cassia Soares, Creciana Maria Endres, Elisa Sonza, Crivian Pelisser, Jaqueline Lidorio de Mattia, Andréia Maria Faion

DOI: $10.36229 / 978-65-5866-067-5 . C A P .08$

Capítulo 9: Produção de xarope hidrolisado de lactose do permeado de soro de leite

Creciana Maria Endres, Bruna Seguenka, Sandrini Slongo Fortuna, Maristela Schleicher Silveira, Vandré Barbosa Brião, Vera Maria Rodrigues

DOI: $10.36229 / 978-65-5866-067-5 . C A P .09$

Capítulo 10: Desenvolvimento, composição nutricional e funcional de suco misto de açaí (Euterpe oleracea Mart.) e acerola (Malpighia glabra L.)..

Silvia Regina Magalhães Couto Garcia, Carolina Pinto de Carvalho Martins, Gabriella Araújo Rebouças Oliveira, Bruna Oliveira de Araújo

DOI: 10.36229/978-65-5866-067-5.CAP.10

Capítulo 11: Desenvolvimento e validação de método utilizando Mekc-Dad para determinação de cafeína e taurina em bebidas energéticas comercializadas no estado de São Paulo 64

Alane Cangani Alves, Adriana Dillenburg Meinhart, Adriana Teixeira Godoy, Helena Teixeira Godoy, José Teixeira Filho

DOI: $10.36229 / 978-65-5866-067-5 . C A P .11$

Capítulo 12: Caracterização físico-química e rendimento na obtenção da carne mecanicamente separada do peixe tibiro (Oligoplites palometa)...

Franky Soedirlan Resosemito, Jaqueline da Silva Rumão, Cleidiana Furtado Teixeira Belfort, Hemily Eduarda Santos Lopes, Andressa Ellen Castro Sousa, Douglas Sodre Ferreira

DOI: $10.36229 / 978-65-5866-067-5 . C A P .12$ 


\section{SUMÁRIO}

Capítulo 13: Caracterização físico-química e composição mineral de diferentes variedades do fruto mirtilo (Vaccinium myrtillus) 85

Guilherme Augusto Rebelatto, Bruna Albiero, Gláucia Freiberger, Rúbia Agostineto, Adriana Biasi Vanin, José Carlos Azzolini, Analu Mantovani

DOI: $10.36229 / 978-65-5866-067-5 . C A P .13$

Capítulo 14: Quantification of ascorbic acid in Amazon fruits 90

Andrezza da Silva Ramos, João Pedro Gallo de Oliveira, Jaqueline de Araújo Bezerra, Marcos Batista Machado

DOI: $10.36229 / 978-65-5866-067-5 . C A P .14$

Capítulo 15: Utilização de peróxido de hidrogênio no controle de microrganismos e vida de prateleira de morangos frescos (Fragaria x ananassa Duch). 96

Ariane Barbo Maretoli, Kaelly Siqueira Horbe, Paula Fernanda Pinto da Costa

DOI: $10.36229 / 978-65-5866-067-5 . C A P .15$

Capítulo 16: Avaliação de filme a base de fibra de colágeno com adição de óleo essencial de pimenta rosa na conservação pós-colheita de morangos 102

Suslin Raatz Thiel, Felipe Ozorio Giacomelli, Mari Silvia Rodrigues de Oliveira, Milena Padilha, Andrine Menna Fontoura, Rosa Cristina Prestes Dornelles

DOI: $10.36229 / 978-65-5866-067-5 . C A P .16$

Capítulo 17: Análise colorimétrica de pão com adição de farinha de bagaço de azeitona 108

Juliana Silveira de Quadros, Jeff Oliveira Soares, Mariane Garcia Orqis Barcellos, João Tomaz Silva Barcellos Junior, Miriane Lucas Azevedo, Fernanda Germano Alves Gautério

DOI: $10.36229 / 978-65-5866-067-5 . C A P .17$

Capítulo 18: Cookies integrais com farinha de baru e jatobá 112

Júlia Nascimento Caldas, Fabrícia Queiroz Mendes

DOI: $10.36229 / 978-65-5866-067-5 . C A P .18$ 


\section{SUMÁRIO}

Capítulo 19: Farinha da casca de feijoa: Caracterização físico-química e potencial antioxidante

Daiana Menin, Ellen Cristina Perin, Ellen de Souza Almeida Duarte, Martha Menin, Edimir Andrade Pereira DOI: 10.36229/978-65-5866-067-5.CAP.19

Capítulo 20: Atuação do tecnólogo em alimentos em uma panificadora no município de Quixeramobim - CE 123

Maria Luciene Monteiro Mendes, Cláudio Gonçalves Paulino, Sheyla Maria Barreto Amaral, Ticiana Leite Costa, Liliane Fernandes do Nascimento

DOI: $10.36229 / 978-65-5866-067-5 . C A P .20$

Autores: 


\section{Capítulo 1}

Aplicação das ferramentas de gestão da segurança de alimentos na merenda escolar: Estudo de caso

Fernanda Carla Henrique-Bana

Viviane Lopes Leite da Costa

Carina Moro Benis

Rebeca Priscila Flora Catarino

Saulo Fabiano Amâncio-Vieira

Maria Tereza Paschoal de Moraes

Vera Lucia Tieko Suguihiro

Wilma Aparecida Spinosa

Resumo: 0 presente trabalho do Núcleo Interdisciplinar de Gestão Pública (NIGEP) objetivou avaliar as condições higiênico-sanitárias das Unidades de Alimentação e Nutrição Escolares (UANEs) do município de Londrina/PR e, simultaneamente, implantar as ferramentas de gestão da qualidade e segurança de alimentos com o intuito de garantir a segurança da merenda escolar de cerca de 15.000 alunos, de acordo com as diretrizes do Programa Nacional de Alimentação Escolar (PNAE). 0 critério de escolha das UANEs pesquisadas foi aleatório e o principal instrumento para a avaliação foi uma lista de verificação estruturada, aplicada pela equipe do NIGEP, por meio de auditorias nos estabelecimentos avaliados. Após a aplicação de medidas corretivas e auditorias em 40 UANEs, o risco sanitário destas diminuiu consideravelmente com as ações do trabalho. A pontuação (conformidade) das UANEs subiu de $72 \%$ na auditoria inicial para 84\% na auditoria final. De maneira geral, a aplicação de ferramentas de gestão da qualidade e segurança de alimentos e a capacitação de gestores e manipuladores resultaram em uma melhoria na qualidade higiênico-sanitária das carnes e hortifrutigranjeiros recebidos nas UANEs e, principalmente, nos procedimentos relacionados às Boas Práticas de Manipulação de alimentos. Nesse sentido, das 40 UANEs que foram atendidas, cerca de 15.000 crianças foram beneficiadas indiretamente com o presente trabalho, por meio da aplicação de ferramentas e metodologias de trabalho que permitem maior eficiência, eficácia e efetividade em gestão pública. Além disso, os resultados das ações implementadas podem trazer para o município a possibilidade de criação de políticas públicas inovadoras que venham somar às existentes, e principalmente, corrigir as falhas que existem nas UANEs.

Palavras-chave: Segurança de alimentos; Gestão da qualidade; Risco sanitário; PNAE. 


\section{INTRODUÇÃO}

A oferta de uma alimentação adequada a todos os alunos matriculados na educação básica das redes públicas estadual, do Distrito Federal e municipal, bem como a garantia à segurança alimentar e nutricional dos alunos são princípios do Programa Nacional de Alimentação Escolar (PNAE). Este Programa foi implantado em 1979 no Brasil, dando continuidade a uma campanha criada na década de 50 e visa assegurar a transferência de recursos financeiros do governo federal para a compra de produtos destinados à merenda escolar. Os beneficiários são os alunos da rede pública de educação infantil, do ensino fundamental e médio, da educação indígena, das áreas remanescentes de quilombos, bem como os alunos da educação especial (Brasil, 2009).

Nesse sentido, o PNAE gerenciado pelo Fundo Nacional de Desenvolvimento da Educação (FNDE) é uma das políticas públicas mais antigas do país e um dos maiores programas de alimentação escolar do mundo, conhecido mundialmente como um caso de sucesso de Programa de Alimentação Escolar Sustentável (Brasil, 2009). O Programa Municipal de Alimentação Escolar (PMAE) integra o PNAE e no município de Londrina, Paraná (PR), atende 120 escolas da rede de Ensino e cerca de 38.000 alunos do ensino infantil e fundamental. O PMAE em Londrina é financiado pelo FNDE com complementação dos recursos pelo governo municipal, sendo que o preparo e distribuição de refeições aos alunos ocorre por meio de prestação de serviços terceirizados contratados pela Prefeitura Municipal de Londrina (PML).

Além da oferta de alimentos equilibrados do ponto de vista nutricional, a merenda escolar deve ser segura do ponto de vista higiênico-sanitário. 0 consumo de alimentos contaminados pode levar as crianças a um quadro infeccioso que pode ser muito grave. Segundo a Organização das Nações Unidas (ONU, 2019), crianças menores de cinco anos carregam $40 \%$ da carga de enfermidades transmitidas por alimentos (ETAs), com 125 mil mortes por ano. A ONU ainda estima que 600 milhões de pessoas - um a cada dez indivíduos no mundo - adoeçam após a ingestão de alimentos contaminados e 420 mil morram a cada ano.

Dessa forma, uma vez que as crianças fazem parte de um grupo de risco para ETAs, as Unidades de Alimentação e Nutrição Escolares (UANEs) devem produzir refeições seguras com a aplicação dos procedimentos relacionados às Boas Práticas de Manipulação (BPM) de alimentos, a fim de garantir a proteção e promoção da saúde dos escolares (Soragni et al., 2019). O cumprimento das legislações sanitárias nas UANEs é imprescindível, a fim de que sejam um suporte alimentar, especialmente aos alunos mais vulneráveis, como é o caso de uma parcela dos escolares do munícipio de Londrina.

De fato, um dos principais benefícios alcançados pela implementação de ferramentas de gestão da qualidade é a redução das ETAs e do desperdício. Adicionalmente, a higiene e a fiscalização dos alimentos constituem um setor fundamental da saúde pública, portanto, investimentos públicos devem estar atrelados à segurança de alimentos. De acordo com a Comissão do Código Sanitário da Junta da Organização das Nações Unidas para Alimentação e Agricultura (FAO, do inglês Food and Agriculture Organization of the United Nations) e da Organização Mundial da Saúde (OMS), a higiene dos alimentos compreende as medidas preventivas necessárias na preparação, manipulação, armazenamento, transporte e venda de alimentos, para garantir produtos inócuos, saudáveis e adequados ao consumo humano. A ideia de higiene está pautada na necessidade de garantir a inocuidade sanitária por meio da diminuição ou exclusão das influências que possam prejudicar a qualidade dos alimentos.

Considerando que dados sobre acompanhamento do processo produtivo da alimentação escolar durante um determinado período de tempo ainda são escassos na literatura, torna-se relevante a pesquisa para conhecer as reais condições higiênico-sanitárias das escolas municipais de ensino infantil e fundamental. Além disso, para que medidas de adequação sejam aplicadas e mantidas nas UANEs é importante a implementação de um sistema de gestão da qualidade de alimentos. De fato, a ausência deste sistema nas UANEs públicas é decorrente da falta de: conhecimento técnico; investimento para monitoramento; condições de higiene; condições operacionais adequadas da cozinha; capacitação da mão-de-obra, ou seja, recursos humanos despreparados; manutenção geral, entre outros fatores.

Diante desse contexto e do fato de as UANEs serem geralmente tratadas como cozinhas residenciais, o objetivo deste trabalho foi avaliar as condições higiênico-sanitárias das UANEs do munícipio de Londrina/PR e implantar as ferramentas de gestão da qualidade de alimentos para garantia da segurança dos alimentos ofertados aos alunos da Rede Municipal de Ensino, de acordo com as diretrizes do PNAE. 


\section{MATERIAL E MÉTODOS}

0 presente estudo caracteriza-se como de delineamento longitudinal, descritivo e exploratório, realizado nas UANEs do município de Londrina-PR, no período de maio de 2019 a junho de 2020. Dessa forma, a amostra é composta por 120 unidades escolares da rede municipal de ensino, sendo 33 Centros Municipais de Educação Infantil (CMEIs) e 87 Escolas Municipais (EMs) de ensino fundamental da zona urbana e rural do munícipio. Para o desenvolvimento do trabalho, discentes e docentes da Universidade Estadual de Londrina (UEL) que integram o Núcleo Interdisciplinar de Gestão Pública (NIGEP) realizaram reuniões com os servidores da Secretaria Municipal de Educação (SME) para definição do cronograma de trabalho.

Inicialmente foi realizado um estudo técnico dos termos de referência utilizados nas compras de produtos cárneos, embutidos e gêneros alimentícios básicos pela PML, de forma a atestar se as descrições e especificações das cláusulas dos editais garantiam a entrega adequada e os critérios de segurança dos alimentos. Em seguida, foi realizado o diagnóstico da situação inicial das UANEs quanto ao atendimento dos requisitos de BPM. A coleta de dados foi realizada em três momentos: 1). Auditoria inicial: aplicação da Lista de Verificação para UANEs desenvolvida pelo Centro Colaborador em Alimentação e Nutrição do Escolar (Cecane, 2012) em parceria com o FNDE para avaliação diagnóstica (auditoria inicial) das condições higiênico-sanitárias das UANEs e levantamento das Não Conformidades encontradas; 2). Visitas in loco para acompanhamento das UANEs, ou seja, aplicação de ações corretivas e esclarecimento de dúvidas; 3) Auditoria Final: nova aplicação da Lista de Verificação para avaliação final (auditoria final) destes serviços de alimentação. $\mathrm{O}$ atendimento às 120 UANEs foi dividido em três fases, sendo até o presente momento realizado em 40 , escolhidas de forma aleatória, de todas as regiões do município.

Adicionalmente, foram elaborados Manuais de BPM de Alimentos e realizados cursos de capacitação aos servidores da SME com o intuito de instrumentalizá-los com as ferramentas de gestão da qualidade utilizadas e, consequentemente, visar a formação de agentes multiplicadores. Os servidores das UANEs que são responsáveis pelo recebimento dos alimentos também foram treinados com instruções técnicas quanto ao correto recebimento dos alimentos. Dessa forma, ao longo do trabalho, a população beneficiada será aproximadamente 150 servidores que atuam no processo de compras e no recebimento dos alimentos, as merendeiras das empresas de mão de obra terceirizadas responsáveis pelo preparo da merenda escolar e indiretamente cerca de 38.000 alunos da Rede Municipal de Ensino.

\section{RESULTADOS E DISCUSSÃO}

Após avaliação diagnóstica do risco sanitário de 40 UANEs, realizada na auditoria inicial, 27 destas apresentaram um risco sanitário regular, 11 com risco sanitário baixo e apenas duas obtiveram uma classificação de risco sanitário alto, conforme ilustrado na Figura 1. A avaliação da pontuação de cada UANE foi baseada na classificação estabelecida pelo Cecane (2012), o qual estabelece uma "Situação de risco sanitário alto" entre 26 a 50\% de conformidade; "Situação de risco sanitário regular" entre 51 a 75\% de conformidade e "Situação de risco sanitário baixo" para as UANEs com 76 a $90 \%$ de conformidade. Nenhuma UANE foi classificada nos extremos de risco sanitário muito alto ou muito baixo.

Figura 1. Pontuação geral das 40 UANEs, na auditoria inicial, em relação ao risco sanitário.

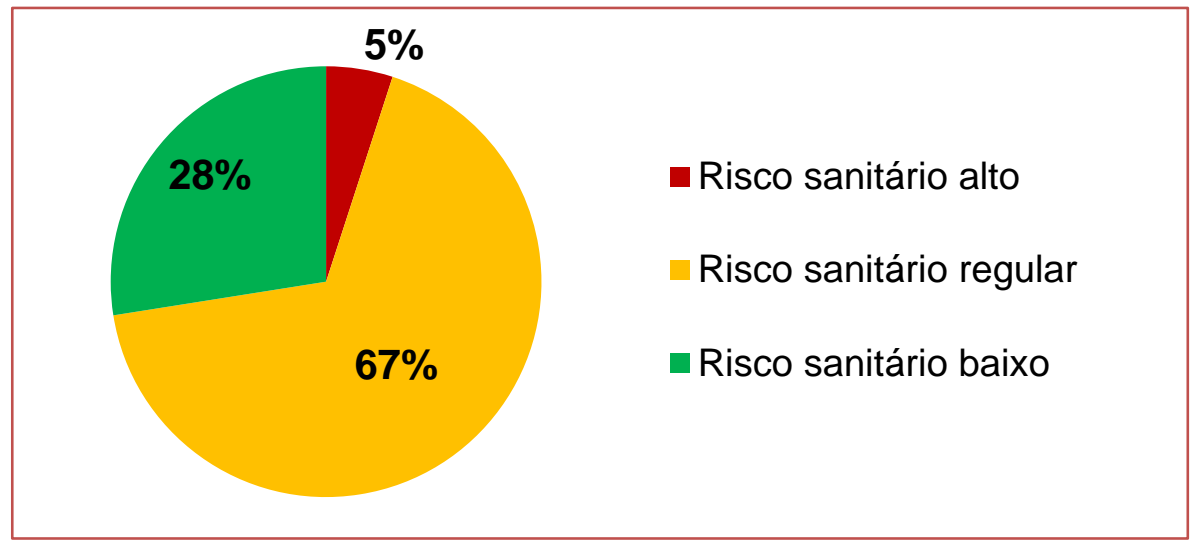

Fonte: Próprio autor. 
A partir destes dados foram elaborados relatórios individuais de cada UANE com a pontuação geral e a pontuação obtida em cada um dos seis blocos avaliados: 1). Processos e procedimentos; 2). Manipuladores; 3). Equipamentos de temperatura controlada, 4). Edifícios e instalações; 5). Fornecedores e 6). Higienização ambiental. De maneira geral, foi possível notar que os procedimentos, equipamentos e estrutura física representaram uma pontuação média similar na classificação das UANEs. Por sua vez, o recebimento dos alimentos e os manipuladores apresentaram a maior pontuação enquanto a higiene ambiental a menor pontuação entre os aspectos avaliados, especialmente devido à falta de documentação requerida pela legislação, tais como registros da higienização do reservatório de água e do controle integrado de vetores e pragas urbanas. Ancorado na legislação federal vigente, a primeira etapa para implantar as boas práticas constitui a aplicação de uma lista de verificação com o intuito de avaliar as não conformidades. Nesse sentido, simultaneamente, foi elaborado um relatório de não conformidades (RNC) e ações corretivas a serem tomadas por cada uma das UANEs (Brasil, 2004).

Após nova avaliação das UANEs, realizada na auditoria final, 36 das 40 UANEs apresentaram risco sanitário baixo, duas um risco sanitário muito baixo e apenas sete obtiveram uma classificação de risco sanitário regular (Figura 2). Após aplicação das ações corretivas e preventivas, nenhuma UANE foi classificada com risco sanitário alto.

Nesse sentido, das 40 UANEs que foram atendidas, cerca de 15.000 crianças foram beneficiadas indiretamente com o presente trabalho. A pontuação (conformidade) das UANEs subiu de $72 \%$ na auditoria inicial para $84 \%$ na auditoria final.

Figura 2. Pontuação geral das 40 UANEs, na auditoria final, em relação ao risco sanitário.

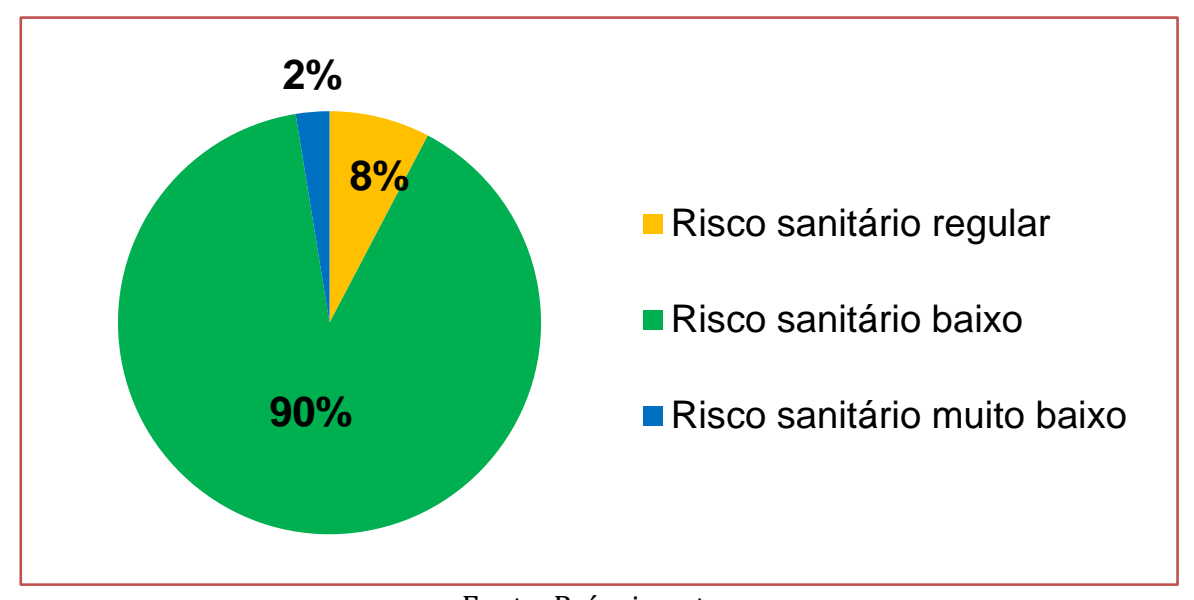

Fonte: Próprio autor.

A higiene ambiental foi o bloco que apresentou a melhoria mais significativa com um aumento de $27 \%$ na pontuação total média, uma vez que na avaliação diagnóstica a pontuação foi de 56\% e na avaliação final obteve $83 \%$. Este aumento se justifica devido às ações corretivas implantadas na higiene de utensílios e equipamentos e na melhoria da qualidade da esponja de pia e sua desinfecção, por exemplo. Além disso, foi efetuado o controle integrado de pragas nas UANEs, que também foram orientadas a manter o registro (laudo) que comprova o serviço realizado. Consequentemente, após dedetização, houve uma diminuição de evidências de roedores, baratas e insetos nas cozinhas que inicialmente apresentavam esta inconformidade.

O segundo bloco que se destacou na melhoria global das UANEs diz respeito aos manipuladores com aumento de $19 \%$ na pontuação total média, visto que na avaliação diagnóstica a pontuação foi de $80 \%$ e na avaliação final obteve 99\%. De acordo com a ANVISA, o Programa de capacitação dos manipuladores em higiene deve ser descrito com o conteúdo programático, a determinação da carga horária e a frequência de sua realização. Na prática, não eram disponibilizados os registros da participação dos manipuladores em capacitações. Durante a avaliação final, foi possível constatar que as empresas realizaram a capacitação e estavam aos poucos disponibilizando os certificados das merendeiras. Além disso, embora ocorresse na minoria das UEs, durante a avaliação diagnóstica foi observado o uso de adornos e ausência do uso de uniforme pelas merendeiras, no entanto, na avaliação final a quase totalidade destas inconformidades foi 
corrigida.

As questões relacionadas aos procedimentos adotados nas cozinhas obtiveram um aumento de $10 \%$ na pontuação total média, uma vez que na avaliação diagnóstica a pontuação foi de $66 \%$ e na avaliação final 76\%. De acordo com a ANVISA, o Manual de Boas Práticas deve ser construído individualmente ao longo de um prazo estabelecido, além de ser específico, ou seja, concebido para cada UE. Dessa forma, este requisito foi cumprido, além dos Procedimentos Operacionais Padronizados (POPs) estarem contemplados em cada Manual. A equipe do presente trabalho elaborou 40 Manuais de BPM de Alimentos com as particularidades de cada UANE, a fim de que estas atendam a legislação vigente sobre os procedimentos que devem ser adotados por serviços de alimentação (Brasil, 2004).

Em relação aos equipamentos para armazenamento em temperatura controlada foi observado um aumento de $8 \%$ na pontuação total média, uma vez que na avaliação diagnóstica a pontuação foi de $74 \%$ e na avaliação final 82\%. Embora algumas UANEs não possuam geladeiras ou câmaras em número suficiente para manutenção dos alimentos em temperatura seguras, as merendeiras foram instruídas sobre a importância da "Zona Térmica de Perigo". Dessa forma, foi realizado o melhor controle da temperatura, por meio do ajuste do termostato para a potência 'média' ou 'máxima' dos refrigeradores e, dessa forma, a maioria dos equipamentos foi regulada para a temperatura correta.

Em relação à infraestrutura das UEs foi observado um aumento de 6\% na pontuação total média, uma vez que na avaliação diagnóstica a pontuação foi de $64 \%$ e na avaliação final $70 \%$. Nesse bloco a principal melhoria foi a higienização das caixas d'água das UEs por empresa especializada e o registro (laudo) que comprova a higienização, como preconiza a ANVISA a cada intervalo máximo de tempo de 180 dias.

De maneira geral, para implementação das BPM de alimentos também foram realizados cursos de capacitação com os servidores da SME para treinamento básico sobre BP. É importante ressaltar que para garantia da qualidade dos alimentos, é de fundamental importância que as UANEs possuam no quadro de funcionários gestores e manipuladores de alimentos com conhecimentos e práticas de trabalho compatíveis às legislações vigentes e requisitos para segurança dos alimentos, além de possuírem e implementarem planos de capacitação periódicos em relação as ferramentas da qualidade.

De acordo com um estudo de Oliveira e colaboradores (2008), as cozinhas de Centros de Educação Infantil do município de São Paulo encontravam-se em condições de funcionamento que ofereciam riscos de contaminação à alimentação produzida nas instituições. Dentre os maiores fatores de risco de contaminação dos alimentos encontravam-se as ações dos manipuladores. Nesse sentido, o investimento em treinamento e supervisão continuada da mão-de-obra envolvida na manipulação de alimentos é considerado o procedimento de maior relevância para a prevenção da contaminação dos alimentos em todo o processo produtivo.

Por fim, a equipe do NIGEP prestou uma assessoria à SME durante os processos de compra e recebimento dos produtos alimentícios, por meio de criação de relatórios e fichas de verificação, tais como: 1). Elaboração de dois relatórios técnicos; 2). Elaboração dos documentos a serem utilizados no recebimento dos alimentos.

\section{CONCLUSÕES}

O presente trabalho tratou de avaliar a aplicação de ferramentas de gestão da qualidade e segurança de alimentos, as quais são de extrema importância para UANEs. Os dados coletados na auditoria inicial evidenciaram uma deficiência na gestão dos processos que podem impactar na segurança de alimentos e, especialmente, falhas das UANEs no atendimento à legislação vigente, o que compromete a qualidade higiênico-sanitária das refeições servidas aos escolares. Por sua vez, na auditoria final, a maioria destas $(90 \%)$ apresentou um risco sanitário baixo, em virtude das ações corretivas aplicadas. A pontuação (conformidade) das UANEs subiu de 72\% na auditoria inicial para 84\% na auditoria final. Dessa forma, é ressaltado a necessidade da implementação de um sistema de gestão de qualidade em UANEs, de forma que atendam às exigências da Resolução do PNAE e da legislação vigente sobre BP.

A aplicação de ferramentas de gestão da qualidade e a capacitação de gestores e manipuladores de alimentos resultaram em uma melhoria na qualidade higiênico-sanitária das carnes e hortifrutigranjeiros recebidos nas UANEs e, principalmente, nos procedimentos relacionados às BPM de alimentos. Nesse sentido, das 40 UANEs que foram atendidas, cerca de 15.000 crianças foram beneficiadas indiretamente com o presente trabalho, o qual consolida o vínculo entre atividade acadêmica e o setor público, com aplicação de ferramentas e metodologias de trabalho que permitem maior eficiência, eficácia e efetividade em gestão 
pública. Além disso, os resultados das ações implementadas podem trazer para o município a possibilidade de criação de políticas públicas inovadoras que venham somar às existentes, e principalmente, corrigir as falhas que existem nas UANEs.

\section{AGRADECIMENTOS}

Os autores agradecem o apoio financeiro da Prefeitura Municipal de Londrina (PML) concedido por meio do contrato administrativo, no SMGP- 0053/2019, dispensa no. DP/SMGP- 0090/2019, processo administrativo PAL/SMGP no. 0416/2019, ato de homologação: 22/04/2019. Além disso, agradecemos o apoio da Fundação de Apoio ao Desenvolvimento da Universidade Estadual De Londrina (FAUEL) e da Pró-Reitoria de Extensão, Cultura e Sociedade (PROEX) da Universidade Estadual de Londrina (UEL).

\section{REFERÊNCIAS}

[1] BRASIL, Ministério da Saúde, Agência Nacional de Vigilância Sanitária. (2004). Regulamento Técnico de Boas Práticas para Serviços de Alimentação (Resolução RDC no 216, de 15 de setembro de 2004). Diário Oficial da República Federativa do Brasil.

[2] BRASIL, Ministério da Educação, Fundo Nacional de Desenvolvimento da Educação. (2009). Dispõe sobre o atendimento da alimentação escolar aos alunos da educação básica no Programa Nacional de Alimentação Escolar PNAE. (Resolução no 38, de 16 de julho de 2009). Diário Oficial da República Federativa do Brasil.

[3] CECANE. Centro Colaborador em Nutrição e Alimentação do Escolar/Fundo Nacional de Desenvolvimento da Educação. (2012). Ferramentas para as Boas Práticas na Alimentação Escolar, versão 1.0. Disponível em: <http://www.rebrae.com.br/eventos_seminarios/manual/guia_de_instrucoes\%20_\%20MPB.pdf>. Acesso em 12 set. 2019.

[4] MESQUITA, M. O. (2014). Procedimentos para avaliação da carne bovina in natura na recepção em serviços de alimentação (Tese de doutorado). Universidade Federal de Santa Maria, Centro de Ciências Rurais, Programa de Pós-Graduação em Ciência e Tecnologia de Alimentos, Santa Maria.

[5] OLIVEIRA, M. M., BRASIL, A. D., TADDEI, J. A. (2008). Avaliação das condições higiênico-sanitárias das cozinhas de creches públicas e filantrópicas. Ciência e Saúde Coletiva, 13(3), 1051-1060.

[6] ORGANIZAÇÕES DAS NAÇÕES UNIDAS (ONU). Em dia mundial, OPAS alerta para importância de garantir segurança dos alimentos. Nações Unidas Brasil, 2019. Disponível em: < https://nacoesunidas.org/em-dia-mundialopas-alerta-para-importancia-de-garantir-seguranca-dos-alimentos/>. Acesso em 15 fev. 2020.

[7] SORAGNI, L., BARNABE, A. S., \& MELLO, T. R. C. (2019). Doenças transmitidas por alimentos e participação da manipulação inadequada para sua ocorrência: uma revisão. Segurança Alimentar e Nutricional, 23(1):837-848. 


\section{Capítulo 2}

Avaliação da adequação da merenda escolar de um Centro Municipal de Educação Infantil do Alto Paranaíba-MG

Rafaela Alexia Ribeiro

Meire de Oliveira Barbosa

Resumo: Avaliar a alimentação oferecida a pré-escolares em um Centro Municipal de Educação Infantil (CMEI). Estudo transversal e observacional onde foi realizada avaliação dietética da merenda escolar. Para tal realizou-se registro alimentar das refeições servidas em três dias não consecutivos e posteriormente foi feita avaliação qualitativa e quantitativa da dieta (valor energético, macronutrientes e micronutrientes e Índice de Qualidade da Dieta Revisado - IQD-R). 0 cardápio ofertado apresentou déficit energético, de cálcio e de ferro. O IQR-R classificou a dieta como "dieta inadequada" (50,4 pontos). Em relação a alimentação, tanto do ponto de vista qualitativo quanto quantitativo foram observadas inadequações. Assim, as crianças desse CMEI são expostas a condições de vulnerabilidade e se faz necessário o desenvolvimento de estratégias de promoção de saúde para melhoria da alimentação no CMEI.

Palavras-Chave: Consumo alimentar; pré-escolares; creche. 


\section{INTRODUÇÃO}

O Brasil passa por um período de transição epidemiológica com mudanças demográficas e nutricionais relevantes. Mudança no estilo de vida da população, aumento da inserção da mulher no mercado de trabalho e as modificações no padrão alimentar (Pereira et al, 2013), são destaques. No que se refere a alimentação, Corrêa et al (2017) observaram uma redução do consumo de alimentos in natura e um aumento no consumo de alimentos com alto teor de energia, sódio, gorduras saturadas e trans, carboidratos refinados que são consumidos por indivíduos de todas as faixas etárias. Alguns estudos vêm correlacionando maior prevalência de desvios nutricionais na infância ao nível socioeconômico familiar. Apesar de ainda não ser bem compreendida essa relação, observou-se que países desenvolvidos, crianças de classes econômicas mais altas possuem maior uma propensão de desenvolverem excesso de peso e nos países em desenvolvimento, o excesso de peso tem sido observado nas famílias de classe socioeconômica baixa. Essa última tem sido justificada, em muitos casos, pela baixa capacidade cognitiva dessa população nas escolhas alimentares (Campos, 2006, Mech, 2016, Rabelo 2016, Wright, 2017). Assim, as creches assistencialistas surgem como alternativa para as famílias, no que se refere a alimentação, especialmente aquelas em condições de vulnerabilidade socioeconômica (Pedraza, 2017).

Avaliar o consumo alimentar de pré-escolares em creches representa uma oportunidade de conhecer a adequação da oferta alimentar nesse espaço. A alimentação deve atender as recomendações nutricionais das crianças do ponto de vista qualitativo e quantitativo, e garantir a ingestão dos nutrientes necessários para o crescimento e o desenvolvimento adequados e auxiliar na formação de hábitos alimentares saudáveis (Inoue et al, 2015, Pedraza et al, 2015). Assim, o objetivo deste trabalho foi avaliar a alimentação oferecida aos pré-escolares de um CMEI de uma cidade do Alto Paranaíba-MG.

\section{MÉTODOS}

Trata-se de uma pesquisa do tipo transversal e observacional, constituída de levantamento e análise de variáveis do cardápio ofertado pela instituição aos pré-escolares. 0 estudo foi desenvolvido em um CMEI, onde são atendidas 106 crianças em período integral, com idade de 2 e 3 anos de idade.

Para avaliação dietética foi feito o registro de todas as preparações que compuseram as refeições servidas no CMEI durante três dias não consecutivos. Para fins de padronização das porções foi feita a pesagem das diferentes preparações servidas pelo CMEI utilizando os utensílios da unidade (copos, talheres, pratos). A seguir, realizou-se de forma observacional, o registro da quantidade servida para os cálculos posteriores.

O cálculo do valor energético e a composição em macro e micronutrientes do cardápio, foi feito no programa Avanutri 4.0., utilizando a média dos três cardápios. Os dados obtidos foram comparados às recomendações do PNAE (crianças de 1 e 3 anos), considerando 70\% das suas necessidades diárias da referida faixa etária, e de acordo com as recomendações das DRIs (Padovani et al, 2006, Brasil, 2013). 0 Índice de Qualidade da Dieta Revisado (IQD-R), foi calculado de acordo com Previdelli et al (2011) e em seguida classificado, onde valores menores de 51 pontos refere-se a uma "dieta inadequada", entre 51 a 80 pontos "dieta necessita de modificações" e acima de 80 pontos "dieta saudável".

O estudo foi desenvolvido após aprovação pelo Comitê de Ética em pesquisa com seres humanos da Universidade Federal de Viçosa - Parecer no 2.652 .843$.

\section{RESULTADOS}

A avaliação do registro alimentar mostrou ausência de oferta de frutas, oferta de leite apenas uma vez e em um único dia (Tabela 1). 
Tabela 1. Alimentos ofertados no CMEI aos pré-escolares durante os 3 dias de registro alimentar, 2019.

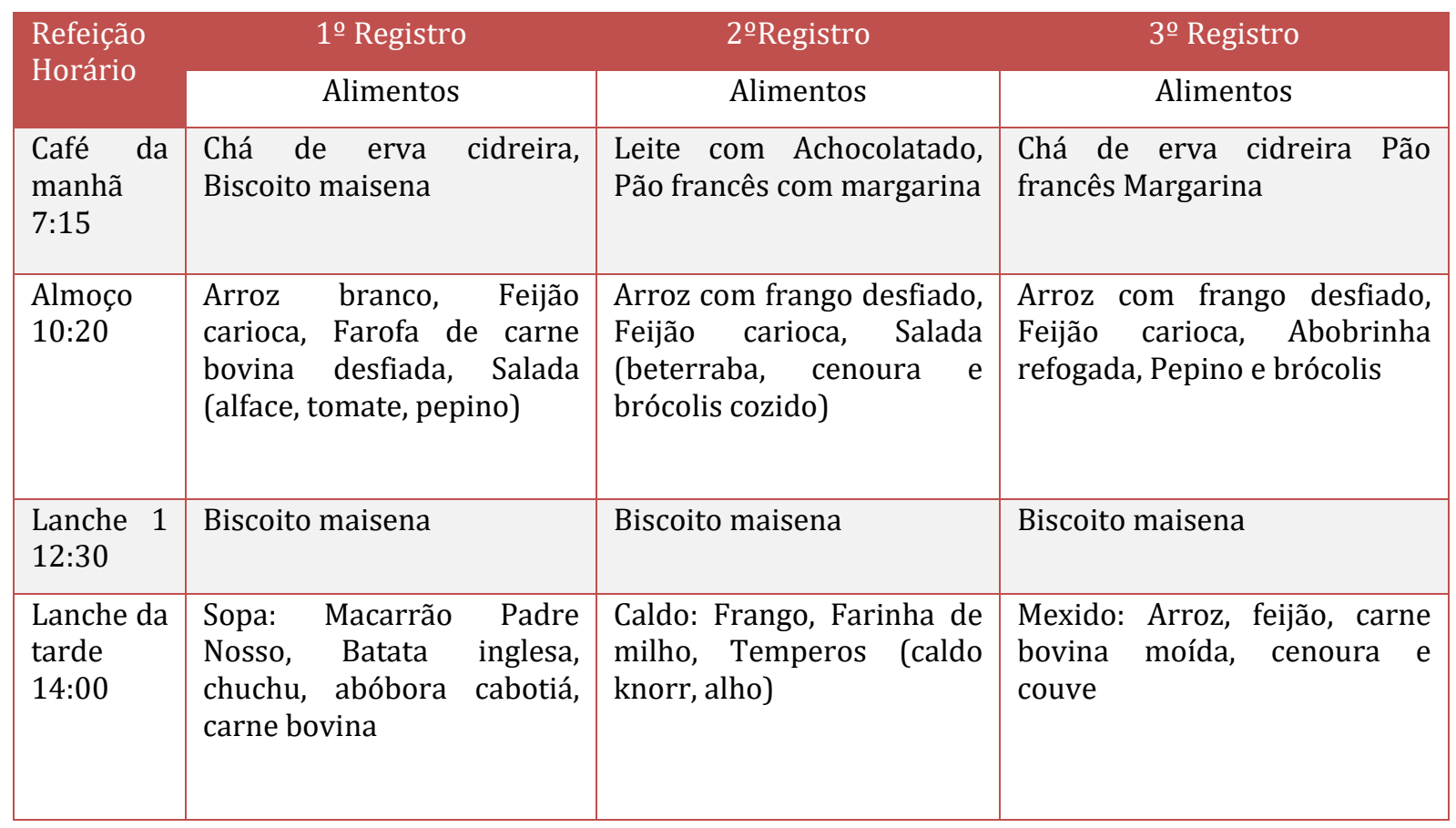

Quando analisada a composição química das refeições ofertadas, observou-se que tanto para a ingestão energética quanto de macronutrientes e micronutrientes, a maioria destes estão aquém das recomendações, conforme pode ser visualizado na Tabela 2.

Tabela 2. Média diária da composição química do cardápio ofertado aos pré-escolares de um CMEI, 2019.

\begin{tabular}{|c|c|c|c|}
\hline Nutriente & Ofertado & Recomendação PNAE/DRIs & Alcançado (\%)* \\
\hline Energia (Kcal) & 457,02 & 700 & 65,28 \\
\hline Carboidratos (g) & 62,63 & 114,9 & 54,51 \\
\hline Proteínas (g) & 25,08 & 21,9 & 114,52 \\
\hline Lipídios (g) & 11,78 & 17,5 & 67,31 \\
\hline Fibras (g) & 6,15 & 13,3 & 46,24 \\
\hline Vitamina A ( $\mu \mathrm{g})$ & 208,62 & 210 & 99,34 \\
\hline Vitamina C (mg) & 9,89 & 12 & 82,41 \\
\hline Cálcio (mg) & 102,1 & 350 & 29,17 \\
\hline Ferro (mg) & 3,28 & 4,9 & 66,93 \\
\hline Magnésio (mg) & 62,05 & 56 & 110,8 \\
\hline Zinco (mg) & 2,34 & 2,1 & 111,42 \\
\hline
\end{tabular}

* Baseado em 70\% das necessidades diárias recomendados pelo PNAE (permanência em tempo integral).

Analisando a qualidade da dieta, foi verificada uma pontuação de 50,4 pontos a qual classificada a dieta como "dieta inadequada"(Tabela 3). 
Tabela 3. IQD-R da merenda dos pré-escolares de um CMEI, 2019.

\begin{tabular}{|l|c|c|}
\hline Componentes * & Porções/g/ \% & 0,0 \\
\hline Frutas totais & 0 & 0,0 \\
\hline Frutas integrais & 0 & 5,0 \\
\hline Vegetais totais & 1,3 & 5,0 \\
\hline Vegetais verdes escuros e alaranjados e leguminosas & 1,0 & 10,0 \\
\hline Cereais totais & 4,3 & 0,0 \\
\hline Cereais integrais & 0 & 0,7 \\
\hline Leite e derivados & 0,07 & 10,0 \\
\hline Carne, ovos e leguminosas & 2,0 & 3,6 \\
\hline Óleos & 0,12 & 6,5 \\
\hline Gordura saturada & $7,7 \%$ & 0,0 \\
\hline Sódio & 2,5 & 9,6 \\
\hline Gord_AA & $27,85 \%$ & $\mathbf{5 0 , 4}$ \\
\hline Pontuação total & & \\
\hline Classificação & Dieta inadequada \\
\hline
\end{tabular}

*Ajustado para 70\% das necessidades diárias recomendadas pelo PNAE (permanecem em tempo integral).

\section{DISCUSSÃO}

A creche é um ambiente favorável para vivência e construção de hábitos, onde as crianças passam boa parte de seu dia, alimentam-se coletivamente e constroem valores, o que foi verificado nesse estudo. Em relação à alimentação, observou-se que o CMEI possui um cardápio, mas que quando avaliado a aquisição dos gêneros para seu preparo, a instituição não possui uma programação de compras e que a maioria dos itens do cardápio são oriundos de doações, as quais, são utilizados prioritariamente, dada sua perecibilidade. Como consequência, alterações nos cardápios são frequentes e com isso prevalece a monotonia alimentar e pouca variedade de alimentos ofertados. Tuma et al. (2003) atribuem a monotonia dos cardápios ao fato dos recursos financeiros limitados e a falta de programas de educação alimentar que incentivem a introdução de novos alimentos. Neste estudo, durante a coleta dos dados não foi observada práticas de orientação e/ou acompanhamento nutricional. Menegazzo et al. (2011) e Silva et al. (2012), ressaltam a necessidade de um monitoramento mais rigoroso na preparação e/ou porcionamento e/ou práticas de oferta dos alimentos.

De acordo com o PNAE, para o público que permanece por tempo integral nas pré-escolas é preconizada a oferta de no mínimo 70\% de suas necessidades nutricionais, distribuídas em, no mínimo, três refeições (Brasil, 2013). 0 número de refeições ofertadas no CMEI atende essa orientação, entretanto em relação aos valores calóricos, macro e micronutrientes em sua maioria essas recomendações não foram alcançadas. Destaca-se o cálcio com maior inadequação, o que pode estar relacionada a oferta de leite em apenas um dia do registro alimentar (Tabela 1). Inoue et al. (2015) ressaltam que atender as recomendações de cálcio nessa faixa etária é essencial para a formação da estrutura dos ossos e dentes. Outro micronutriente com oferta abaixo das recomendações foi o ferro. Castro et al (2005), em estudo realizado em creches municipais de Viçosa - MG, encontraram inadequação de ferro na dieta das crianças, e ressaltaram que a oferta de alimentos ricos em ferro biodisponível devem ser atingidas para corrigir ou prevenir anemias tão comuns em pré-escolares. As fibras também ficaram aquém das recomendações sendo podendo esta estar relacionada a ausência de frutas e quantidades insuficientes de verduras e legumes no cardápio. Ressalta-se a importância das fibras alimentares nos primeiros anos de vida, visando evitar a obstipação intestinal e promover a saciedade (Inoue et al., 2015).

A avaliação da qualidade da dieta ofertada (IQD-R), classificou a dieta do CMEI como "dieta inadequada". Almeida et al (2014) encontraram pontuação de 60,84 ("dieta necessita de modificações") e concluíram 
que todas as crianças apresentaram baixo consumo de cereais, hortaliças, frutas e leite e derivados, o que corrobora com este estudo. Destacaram ainda que essa baixa ingestão representa fator de risco para doenças sendo necessário o estímulo a mudanças no hábito alimentar. Silva et al. (2012) relataram que, apesar das recomendações do PNAE, observa-se ainda que o cardápio proposto para as creches nem sempre atende os critérios de adequação qualitativa e quantitativa de sua composição, e por consequência não é obtido o êxito no fornecimento de refeições adequadas nutricionalmente para as crianças durante o período de sua permanência na creche. 0 não atendimento dessas diretrizes, podem comprometer o crescimento e desenvolvimento das crianças, colaborando para o aumento dos distúrbios e carências nutricionais, déficts cognitivos e preditor para as prevalências de desvios nutricional nessa faixa etária (Alencar et al, 2016).

A adesão ao PNAE deve ser pautada para melhorias na alimentação, o que impacta diretamente nos cardápios oferecidos nas creches, cujo propósito é colaborar diretamente para a construção de hábitos alimentares saudáveis (Prado et al, 2015). Ainda que os cardápios ofertados em creches públicas do país sejam desenvolvidos por profissionais habilitados, provavelmente há falhas no processo de aquisição e/ou de preparo da alimentação relacionadas ao porcionamento e/ou forma de oferecimento das refeições (Menegazzo et al, 2011), como observado também em nosso estudo. As deficiências de nutrientes, em especial nos pré-escolares, podem ser causadas pela ingestão dietética insuficiente e em algumas situações excessivas. Há uma associação positiva entre déficit de crescimento e desenvolvimento e consumo alimentar inadequado; além da presença de sobrepeso e obesidade associada a baixa estatura (Castro et al 2005). Quando a alimentação é insuficiente pode levar à carência de micronutrientes causando imaturação biológica, especificamente dos sistemas nervoso e imune. Além disso, um baixo aporte energético pode levar à desnutrição infantil que está fortemente associada a menor produtividade, tanto na área escolar como na área profissional. Por outro lado, a ingestão dietética em excesso está associada à ocorrência, a médio e longo prazo, de doenças crônicas não transmissíveis como obesidade, dislipidemia, hipertensão arterial, diabetes (Alves et al, 2013).

\section{CONCLUSÃO}

A alimentação oferecida no CMEI se mostrou aquém das recomendações preconizadas pelo PNAE do ponto de vista qualitativo e quantitativo de acordo com a composição química e IQD-R. Portanto, diante da insegurança nutricional relacionada à má qualidade da dieta, torna-se necessária a adoção de medidas a fim de melhorar a alimentação e prevenir distúrbios nutricionais e problemas futuros de saúde para as crianças.

\section{REFERÊNCIAS}

[1] Almeida, I. S., Sperandio, N. \& Priore, S. E. (2014). Qualidade da dieta de pré-escolares beneficiados pelo Programa Bolsa Família, segundo a situação de Segurança Alimentar do domicílio. Revista Nutrire, 39(3), 297-305.

[2] Alves M. N., Muniz, L. C. \& Vieira M.F.A. (2013). Consumo alimentar entre crianças brasileiras de 2 a 5 anos de idade: Pesquisa Nacional de Demografia e Saúde (PNDS), 2006. Ciência Saúde Coletiva, 18(11), 3369-3377.

[3] Brasil. Ministério da Educaçao e Cultura. (2013). Dispõe sobre o atendimento da alimentação escolar aos alunos da educação básica no âmbito do Programa Nacional de Alimentação Escolar - PNAE (Resolução no 26, de 17 de junho de 2013). Diário Oficial da República Federativa

[4] Campos, L. A., Leite, Á. J. M. \& Almeida, P. C. (2006). Nível socioeconômico e sua influência sobre a prevalência de sobrepeso e obesidade em escolares adolescentes do município de Fortaleza. Revista de Nutrição, 19(5), 531-538, 2006.

[5] Castro, T. G., Novaes, J. F., Silva, M. R., Costa, N. M. B., Franceschini, S. C. C \& Tinôco, A. L. A. (2005) Caracterização do consumo alimentar, ambiente socioeconômico e estado nutricional de pré-escolares de creches municipais. Revista de Nutrição, 18(3), 321-330.

[6] Corrêa, R. S., Vencato, P. H., Rockett, F. C. \& Bosa, V. L. (2017) Padrões alimentares de escolares: existem diferenças entre crianças e adolescentes? Ciência Saúde Coletiva, 22(2), 553-562.

[7] Inoue, D. Y., Osório, M. M., Taconeli, C. A., Schmidt, S. T. \& Almeida, C. C. B. (2015) Consumo alimentar de crianças de 12 a 30 meses que frequentam Centros Municipais de Educação Infantil no município de Colombo, Sul do Brasil. Revista de Nutrição, 28(5), 523-532. 
[8] Janssen, I., Boyce, W. F., Simpson, K. \& Pickett, W. (2006) Influence of individual- and area-level measures of socioeconomic status on obesity, unhealthy eating, and physical inactivity in Canadian adolescents. The American Journal of Clinical Nutrition, 83(1), 39-45.

[9] Mech, P., Hooley, M., Skouteris, H. \& Williams, J. Parent-related mechanisms underlying the social gradient of childhood overweight and obesity: a systematic review. Child: care, health and development, 42 (5),603-624.

[10] Menegazzo, M., Fracalossi, K., Fernandes, A. C. \& Medeiros, N.I. (2011). Avaliação qualitativa das preparações do cardápio de centros de educação infantil. Revista de Nutrição, 24(2), 243-251.

[11] Padovani, R.M., Amaya-Farfán, J., Colugnati, F. A. B., Domene, S. M. A. (2006) Dietary reference intakes: aplicabilidade das tabelas em estudos nutricionais. Revista Nutrição, 19(6),741-760.

[12] Pedraza DF, Queiroz D, Gama J S FA. Avaliação do consumo alimentar de crianças brasileiras assistidas em creches: uma revisão sistemática. Rev. Bras. Saude Mater. Infant. 2015;15(1):17-31.

[13] Pedraza, D. F.(2017) Preditores de riscos nutricionais de crianças assistidas em creches em município de porte médio do Brasil. Caderno Saúde Coletiva, 25(1),14-23.

[14] Pereira, A. S., Peixoto, N. G. A., Nogueira, N. J. F., Lanzillotti, H. S. \& Soares, E. A. (2013). Estado nutricional de pré-escolares de creche pública: um estudo longitudinal. Caderno Saúde Coletiva, 21(2),140-147.

[15] Prado, B.G., Hinnig, P.F., Tanaka, L.F. \& Latorre, M.R.D.O. (2015). Qualidade da dieta de escolar de 7 a 10 anos do município de São Paulo: associação com o número e os locais de refeições. Revista Nutrição, 28(6),607-618.

[16] Previdelli, N. A., Andrade, S. C., Pires, M. M. , Ferreira, S. R. G., Fisberg, R. M. \& Marchioni, D. M.(2011). Índice de Qualidade da Dieta Revisado para população brasileira. Revista Saúde Pública, 45(4),794-798.

[17] Rabelo, D. M. R. S. (2017) Influência de características populacionais na determinação de fatores de risco relacionados ao sobrepeso/obesidade infantil. Revista Conexão Ciência, 12(3), 55-66.

[18] Silva, G.L., Toloni, M. H. A, Goulart, R. M. M \& Taddei, J. A. A. C. (2012). Avaliação do consumo alimentar em creches públicas em São Paulo, Brasil. Revista Paulista Pediatria, 30(1),35-41.

[19] Tuma, R. B., Yuyama, L. K. O., Aguiar, J. P. L., Marques, H.O. (2003). Impacto da farinha de mandioca fortificada com ferro aminoácido quelato no nível de hemoglobina de pré-escolares. Revista Nutrição, 16(1), 29-39. 


\section{Capítulo 3}

\section{Análise qualitativa da alimentação escolar de uma unidade de educação infantil}

\section{Kellen Schaaff Souto}

Carla Cristina Bauermann Brasil

Susana Berleze de Pelegrini

Resumo: Para analisar qualitativamente os cardápios da alimentação escolar de uma unidade de educação infantil utilizou-se o Índice de Qualidade da Coordenação de Segurança Alimentar e Nutricional (IQ COSAN) do Programa Nacional de Alimentação Escolar (PNAE). 0 presente estudo objetivou avaliar os cardápios do Serviço de Alimentação Escolar (SAE) de uma Unidade de Educação Infantil da região central do Rio Grande do Sul. Trata-se de um estudo descritivo do tipo transversal, o qual avaliou a presença diária dos parâmetros qualitativos presentes em três cardápios do SAE. Primeiramente, foi realizada a avaliação diária dos componentes da semana 1, 2 e 3 e logo em seguida foi realizada a avaliação semanal do cardápio. A ferramenta IQ COSAN calcula o resultado de cada semana, e posteriormente classifica a adequação do cardápio às diretrizes do PNAE e aos pilares de uma alimentação adequada e saudável. Dessa forma, os cardápios avaliados foram considerados adequados, pois a oferta destes alimentos está variada e possibilita aos escolares a prática alimentar saudável. Ainda, destaca-se que o PNAE tem por objetivo contribuir para o crescimento e o desenvolvimento biopsicossocial, a aprendizagem, o rendimento escolar e a formação de hábitos alimentares saudáveis dos escolares, por meio de ações de educação alimentar e nutricional e da oferta de refeições que garantam as necessidades nutricionais durante $o$ período letivo. Portanto, a aplicação desta ferramenta torna-se importante para auxiliar o profissional nutricionista no momento de avaliar a qualidade dos cardápios.

Palavras-Chave: cardápio; alimentação escolar; segurança alimentar. 


\section{INTRODUÇÃO}

De acordo com o Fundo Nacional de Desenvolvimento da Educação (FNDE) (2018) o Programa Nacional de Alimentação Escolar (PNAE) é a mais antiga e mais abrangente política pública de Segurança Alimentar e Nutricional (SAN) do Brasil, tendo origem na década de 1940 e marco legal no ano de 2009. Ao longo deste percurso, o programa tem apresentado avanços significativos com relação a seus objetivos, gestão, execução, abrangência e articulação intersetorial. O PNAE é gerenciado pelo FNDE, sendo vinculado ao Ministério da Educação, o qual executa a transferência, em caráter suplementar, de recursos financeiros aos Estados, ao Distrito Federal e aos municípios destinados a suprir, parcialmente, as necessidades nutricionais dos alunos (FNDE, 2020; MENDES et al., 2020).

O PNAE tem como principal objetivo contribuir para o crescimento e o desenvolvimento dos escolares, com o intuito de melhorar o desenvolvimento na aprendizagem, rendimento escolar e a formação de práticas alimentares saudáveis, por meio de ações de educação alimentar e nutricional e da oferta de refeições que cubram as suas necessidades nutricionais durante o período letivo. Apresenta diretrizes para atingir o objetivo principal desta política pública que se resume em: alimentação saudável e adequada, educação alimentar e nutricional, universalização, desenvolvimento sustentável e o direito à alimentação nas escolas (FNDE, 2020).

Conforme disposto no Art. 12 da Lei 11.947 de 2009 (BRASIL, 2009), os cardápios da alimentação escolar deverão ser criteriosamente planejados pelo nutricionista responsável com utilização de gêneros alimentícios básicos, respeitando-se as referências nutricionais, os hábitos alimentares, a cultura e a tradição alimentar da localidade, priorizando a sustentabilidade e incentivando a agricultura familiar (BRASIL, 2013; MENDES et al., 2020). Assim, é de suma importância a presença de um nutricionista para o desenvolvimento dos escolares, pois a introdução de uma alimentação balanceada e rica em nutrientes faz com que as crianças tenham melhor desenvolvimento físico, cognitivo e maior disposição para realização de suas atividades.

Para uma avaliação adequada do escolar, a fim de garantir as necessidades nutricionais concernentes ao período diário letivo, é indispensável a utilização de indicadores quantitativos e/ou qualitativos que possibilitem a análise da qualidade global das refeições planejadas. Assim, em 2018 a Coordenação de Segurança Alimentar e Nutricional (COSAN), a fim de avaliar qualitativamente a alimentação escolar definiu uma ferramenta de padronização que garantisse uma avaliação prática e isenta de ponderações subjetivas, denominada como Índice de Qualidade da Coordenação de Segurança Alimentar e Nutricional (IQ COSAN) (FNDE, 2020b). 0 principal objetivo do IQ COSAN é a padronização das análises dos cardápios, não somente pela equipe técnica do FNDE, mas também por nutricionistas e demais atores que atuam no âmbito do PNAE, que desejam verificar se os cardápios elaborados atendem às diretrizes do Programa e aos pilares de uma alimentação adequada e saudável (FNDE, 2020). De acordo com Neta (2019), o IQ COSAN é baseado nas leis vigentes do PNAE, partindo do princípio de que a ocorrência de alimentos por grupos pode se configurar em um sensível marcador de qualidade de cardápio (NETA, 2019).

Ainda, essa ferramenta objetiva a padronização dos cardápios realizados pela equipe técnica da COSAN, nutricionistas que atuem no âmbito do PNAE, equipes técnicas dos Centros Colaboradores em Alimentação e Nutrição Escolar (CECANEs) e, entre outros atores envolvidos na alimentação escolar. É um instrumento de fácil utilização e acesso, elaborado no programa Excel, que por meio da concessão de pontos, analisa os cardápios da alimentação escolar.

Assim, o presente estudo teve por objetivo verificar os cardápios do Serviço de Alimentação Escolar (SAE) de uma Unidade de Educação Infantil da região central do Rio Grande do Sul utilizando a ferramenta do IQ COSAN.

\section{MATERIAL E MÉTODOS}

Trata-se de estudo descritivo do tipo transversal, que visa avaliar qualitativamente os cardápios de uma Unidade de Educação Infantil (UEI) da região central do Rio Grande do Sul. A Unidade atende às crianças em turnos integral, parcial manhã e parcial tarde, sendo que estes turnos compreendem os horários das 8 às 17 horas, das 8 às $12 \mathrm{~h} 30 \mathrm{~min}$ e das $12 \mathrm{~h} 30 \mathrm{~min}$ às 17 horas, respectivamente.

Atualmente, o SAE da UEI oferece alimentação para um total de 85 crianças, sendo 52 em turno integral, 9 em turno manhã e 24 em turno tarde, o que totaliza 61 crianças nas refeições de colação e de almoço e 76 crianças nas refeições de lanche da tarde e de jantar. Assim, o SAE serve aproximadamente 274 refeições diariamente. 
São padronizados três tipos de cardápios: cardápio para o berçário de 6 meses a 1 ano, cardápio para o berçário de 1 a 2 anos e cardápio para as turmas multi-idades. Além disso, caso haja alguma criança com necessidades nutricionais específicas, são realizadas alterações nos cardápios ou, então, é elaborado um cardápio de acordo com a necessidade específica da criança.

Para que os cardápios sejam calculados e classificados por meio do IQ COSAN, eles devem ser referentes aos cinco dias da semana. Semanas com menos dias foram desconsideradas. Com isto, realizou-se a análise dos cardápios ofertados as turmas multi-idades, desconsiderando-se os cardápios de duas semanas do ano letivo, pois não preenchiam o critério da ferramenta de avaliação de ter cinco dias na semana. Além disso, após este período a UEI foi fechada devido à pandemia e não teve mais o fornecimento de refeições às crianças. Sendo assim, entraram no critério de inclusão para análise três cardápios das turmas multiidades, oferecidos no período de fevereiro e março de 2020.

Os cardápios foram analisados pela presença diária de:

a) Seis grupos de alimentos, sendo eles: grupos dos cereais e tubérculos; grupos dos feijões; grupos dos legumes e verduras; grupo das frutas in natura; grupos dos leites e derivados e grupo das carnes e ovos.

A ferramenta pontua positivamente a presença dos seis grupos de alimentos em 2 pontos.

b) Alimentos classificados como restritos pela resolução vigente do programa.

c) Alimentos e preparações doces.

A ausência de alimentos restritos e doces pontua positivamente em 2 pontos.

Os cardápios foram analisados semanalmente levando em consideração a oferta de:

a) Alimentos regionais;

b) Alimentos da sociobiodiversidade;

c) Diversidade/variedade do cardápio (no mínimo 25 alimentos diferentes por semana para a oferta de 70\% das necessidades nutricionais diárias);

d) Presença de alimentos definidos como proibidos pela legislação atual e que, portanto, não devem ser adquiridos com verba federal.

A pontuação dos alimentos regionais e da sociobiodiversidade pontua em 2,5 pontos. A diversidade do cardápio 10 pontos. Por outro lado, pontua negativamente a presença de alimentos classificados como proibidos -10 pontos.

Ao final da avaliação destes parâmetros a ferramenta soma a pontuação de cada semana e realiza o cálculo das médias semanais. 0 escore do IQ COSAN varia entre 0 e 95 pontos e classifica os cardápios em Inadequado ( 0 a 45,9 pontos), Precisa de melhoras ( 46 a 75,9 pontos) e Adequado ( 76 a 95 pontos). Para a apresentação dos resultados, foi realizada uma média dos três cardápios mensais ofertados.

\section{RESULTADOS E DISCUSSÃO}

A análise qualitativa dos cardápios pela ferramenta IQ COSAN está expressa nos Quadros 1, 2, 3, 4, 5, 6 e 7. Os resultados serão apresentados considerando separadamente os componentes da avaliação diária e semanal.

Os Quadros 1, 2 e 3 apresentam os resultados dos componentes da avaliação diária dos 6 grupos alimentares, que ao longo dos cinco dias das semanas 1, 2 e 3 aparecem nos cardápios. 
Quadro 1: Pontuação dos Componentes da Avaliação Diária dos Cardápios do SAE.

\begin{tabular}{|c|c|c|c|c|c|c|c|}
\hline \multicolumn{8}{|c|}{$\begin{array}{c}\text { Índice de Qualidade de Cardápios COSAN } \\
\text { COMPONENTES SEMANA } 1\end{array}$} \\
\hline $\begin{array}{l}\text { COMPONENTES DE AVALIAÇÃO } \\
\text { DIÁRIA }\end{array}$ & Ref & Seg & Ter & Qua & Qui & Sex & Resultado \\
\hline $\begin{array}{l}\text { Presença de alimentos do grupo } \\
\text { dos cereais e tubérculos }\end{array}$ & 2 & 2 & 2 & 2 & 2 & 2 & 10 \\
\hline $\begin{array}{l}\text { Presença de alimentos do grupo } \\
\text { dos feijões }\end{array}$ & 2 & 2 & 2 & 2 & 2 & 2 & 10 \\
\hline $\begin{array}{l}\text { Presença de alimentos do grupo } \\
\text { dos legumes e verduras }\end{array}$ & 2 & 2 & 2 & 2 & 2 & 2 & 10 \\
\hline Presença de frutas in natura & 2 & 2 & 2 & 2 & 2 & 2 & 10 \\
\hline $\begin{array}{l}\text { Presença de alimentos do grupo } \\
\text { leite e derivados }\end{array}$ & 2 & 0 & 0 & 0 & 2 & 0 & 2 \\
\hline $\begin{array}{l}\text { Presença de alimentos do grupo } \\
\text { das carnes e ovos }\end{array}$ & 2 & 2 & 2 & 2 & 2 & 2 & 10 \\
\hline Ausência de alimentos restritos & 2 & 2 & 2 & 2 & 2 & 2 & 10 \\
\hline $\begin{array}{l}\text { Ausência de alimentos e } \\
\text { preparações doces }\end{array}$ & 2 & 2 & 2 & 2 & 2 & 2 & 10 \\
\hline \multicolumn{7}{|c|}{ PONTUAÇÃO } & 72 \\
\hline
\end{tabular}

Fonte: Autores, 2020.

Quadro 2: Pontuação dos Componentes da Avaliação Diária dos Cardápios do SAE.

\begin{tabular}{|c|c|c|c|c|c|c|c|}
\hline \multicolumn{8}{|c|}{$\begin{array}{c}\text { Índice de Qualidade de Cardápios COSAN } \\
\text { COMPONENTES SEMANA } 2\end{array}$} \\
\hline $\begin{array}{l}\text { COMPONENTES DE } \\
\text { AVALIAÇÃO DIÁRIA }\end{array}$ & Ref & Seg & Ter & Qua & Qui & Sex & Resultado \\
\hline $\begin{array}{l}\text { Presença de alimentos do grupo } \\
\text { dos cereais e tubérculos }\end{array}$ & 2 & 2 & 2 & 2 & 2 & 2 & 10 \\
\hline $\begin{array}{l}\text { Presença de alimentos do grupo } \\
\text { dos feijões }\end{array}$ & 2 & 2 & 2 & 2 & 2 & 2 & 10 \\
\hline $\begin{array}{l}\text { Presença de alimentos do grupo } \\
\text { dos legumes e verduras }\end{array}$ & 2 & 2 & 2 & 2 & 2 & 2 & 10 \\
\hline \multirow{2}{*}{$\begin{array}{l}\text { Presença de frutas in natura } \\
\text { Presença de alimentos do grupo } \\
\text { leite e derivados }\end{array}$} & 2 & 2 & 2 & 2 & 2 & 2 & 10 \\
\hline & 2 & 0 & 2 & 2 & 2 & 0 & 6 \\
\hline $\begin{array}{l}\text { Presença de alimentos do grupo } \\
\text { das carnes e ovos }\end{array}$ & 2 & 2 & 2 & 2 & 2 & 2 & 10 \\
\hline Ausência de alimentos restritos & 2 & 2 & 2 & 2 & 2 & 2 & 10 \\
\hline $\begin{array}{l}\text { Ausência de alimentos e } \\
\text { preparações doces }\end{array}$ & 2 & 2 & 2 & 2 & 2 & 2 & 10 \\
\hline \multicolumn{7}{|c|}{ PONTUAÇÃO } & 76 \\
\hline
\end{tabular}

Fonte: Autores, 2020. 
Quadro 3: Pontuação dos Componentes da Avaliação Diária dos Cardápios do SAE.

\begin{tabular}{|c|c|c|c|c|c|c|c|}
\hline \multicolumn{8}{|c|}{$\begin{array}{c}\text { Índice de Qualidade de Cardápios COSAN } \\
\text { COMPONENTES SEMANA } 3\end{array}$} \\
\hline COMPONENTES DE AVALIAÇÃO DIÁRIA & Ref & Seg & Ter & Qua & Qui & Sex & Resultado \\
\hline $\begin{array}{l}\text { Presença de alimentos do grupo dos } \\
\text { cereais e tubérculos }\end{array}$ & 2 & 2 & 2 & 2 & 2 & 2 & 10 \\
\hline $\begin{array}{l}\text { Presença de alimentos do grupo dos } \\
\text { feijões }\end{array}$ & 2 & 2 & 2 & 2 & 2 & 2 & 10 \\
\hline $\begin{array}{l}\text { Presença de alimentos do grupo dos } \\
\text { legumes e verduras }\end{array}$ & 2 & 2 & 2 & 2 & 2 & 2 & 10 \\
\hline Presença de frutas in natura & 2 & 2 & 2 & 2 & 2 & 2 & 10 \\
\hline $\begin{array}{l}\text { Presença de alimentos do grupo leite e } \\
\text { derivados }\end{array}$ & 2 & 2 & 2 & 0 & 0 & 2 & 6 \\
\hline $\begin{array}{l}\text { Presença de alimentos do grupo das } \\
\text { carnes e ovos }\end{array}$ & 2 & 2 & 2 & 2 & 2 & 2 & 10 \\
\hline Ausência de alimentos restritos & 2 & 0 & 2 & 2 & 2 & 2 & 8 \\
\hline $\begin{array}{l}\text { Ausência de alimentos e preparações } \\
\text { doces }\end{array}$ & 2 & 2 & 2 & 2 & 2 & 2 & 10 \\
\hline \multicolumn{7}{|c|}{ PONTUAÇÃo } & 74 \\
\hline
\end{tabular}

Fonte: Autores, 2020.

Para a avaliação semanal da variedade dos cardápios, foram classificados como adequados considerando a oferta de 25 diferentes alimentos ou mais representativos dos grupos alimentares para os cardápios que ofertam 3 refeições/dia ou atendam a $70 \%$ das necessidades nutricionais dos escolares. Visto que, quanto mais variada for a alimentação, maior o número de alimentos considerados adequados.

A oferta de alimentos regionais apresentou como resultado 2,5 pontos em todos os cardápios avaliados. Os alimentos encontrados nos cardápios classificados como regionais pela ferramenta são: morango, uva, maçã, batata-doce, batata-inglesa, pêssego, uva e melão.

Os alimentos da sociobiodiversidade não pontuaram, pois, sua presença não foi observada nos cardápios avaliados. É importante ressaltar que não houve a oferta de alimentos proibidos pela ferramenta e legislação vigente (Quadro 4, 5, 6).

Quadro 4: Pontuação dos Componentes da Avaliação da Semana 1 dos Cardápios do SAE.

\begin{tabular}{|c|c|c|c|c|c|c|}
\hline \multicolumn{4}{|c|}{ COMPONENTES DE AVALIAÇÃ̃O SEMANAL } & Resultado & Referência & Observação \\
\hline \multicolumn{4}{|c|}{ Oferta de alimentos regionais? } & 2,5 & 2,5 & $\begin{array}{c}\text { Morango, } \\
\text { uva, maçã, } \\
\text { batata doce. }\end{array}$ \\
\hline \multicolumn{4}{|c|}{ Oferta de alimentos da sociobiodiversidade? } & 0 & 2,5 & \\
\hline \multirow{2}{*}{$\begin{array}{l}\text { Diversidade } \\
\text { do cardápio }\end{array}$} & \multirow{2}{*}{$\begin{array}{c}1 \mathrm{refs} / \text { dia ou } \\
20 \% \mathrm{NND}^{*}\end{array}$} & $\begin{array}{c}2 \text { refs/dia ou } \\
30 \% \text { NND* }^{*}\end{array}$ & $\begin{array}{c}3 \text { refs/dia } \\
\text { ou } 70 \%\end{array}$ & \multirow[t]{2}{*}{10} & \multirow[t]{2}{*}{10} & \\
\hline & & 35 & & & & \\
\hline \multicolumn{4}{|c|}{ Oferta de alimentos proibidos } & 0 & -10 & \\
\hline
\end{tabular}

Fonte: Autores, 2020.

*Necessidades Nutricionais Diárias. 
Quadro 5: Pontuação dos Componentes da Avaliação da Semana 2 dos Cardápios do SAE.

\begin{tabular}{|c|c|c|c|c|c|c|}
\hline \multicolumn{4}{|c|}{ COMPONENTES DE AVALIAÇÃO SEMANAL } & Resultado & Referência & Observação \\
\hline \multicolumn{4}{|c|}{ Oferta de alimentos regionais? } & 2,5 & 2,5 & $\begin{array}{l}\text { Uva, maçã, batata- } \\
\text { doce e batata-inglesa }\end{array}$ \\
\hline \multicolumn{4}{|c|}{ Oferta de alimentos da sociobiodiversidade? } & 0 & 2,5 & \\
\hline \multirow{2}{*}{$\begin{array}{l}\text { Diversidade do } \\
\text { cardápio }\end{array}$} & \multirow{2}{*}{$\begin{array}{c}1 \mathrm{refs} / \text { dia ou } \\
20 \% \mathrm{NND}^{*}\end{array}$} & \multirow{2}{*}{$\begin{array}{c}2 \text { refs/dia ou } \\
30 \% \text { NND* }\end{array}$} & $\begin{array}{c}3 \text { refs/dia ou } \\
70 \% \text { NND* }^{*}\end{array}$ & \multirow[t]{2}{*}{10} & \multirow[t]{2}{*}{10} & \\
\hline & & & 52 & & & \\
\hline \multicolumn{4}{|c|}{ Oferta de alimentos proibidos } & 0 & -10 & \\
\hline
\end{tabular}

Fonte: Autores, 2020.

Quadro 6: Pontuação dos Componentes da Avaliação da Semana 3 dos Cardápios do SAE.

\begin{tabular}{|c|c|c|c|c|c|c|}
\hline & & & & Resultado & Referência & Observação \\
\hline \multicolumn{4}{|c|}{ Oferta de alimentos regionais? } & 2,5 & 2,5 & $\begin{array}{l}\text { Morango, maçã, } \\
\text { pêssego, uva, } \\
\text { melão, batata- } \\
\text { doce e batata- } \\
\text { inglesa. }\end{array}$ \\
\hline \multicolumn{4}{|c|}{ Oferta de alimentos da sociobiodiversidade? } & 0 & 2,5 & \\
\hline $\begin{array}{l}\text { Diversidade do } \\
\text { cardápio }\end{array}$ & $\begin{array}{c}1 \text { refs/dia ou } \\
20 \% \text { NND* }^{*}\end{array}$ & $\begin{array}{c}2 \text { refs/dia ou } \\
30 \% \text { NND}^{*}\end{array}$ & $\begin{array}{r}3 \text { refs/dia ou } \\
70 \% \text { NND }^{*} \\
50\end{array}$ & 10 & 10 & \\
\hline \multicolumn{4}{|c|}{ Oferta de alimentos proibidos } & 0 & -10 & \\
\hline
\end{tabular}

Fonte: Autores, 2020.

O FNDE recomenda que o cardápio atinja uma pontuação desejável entre (76 a 95 pontos), ou seja, atende a maioria dos seguintes aspectos: adequada oferta de grupos alimentares, alta diversidade de alimentos, baixa oferta de alimentos restritos ou doces, ausência de alimentos proibidos e oferta de alimentos regionais ou da sociobiodiversidade. 0 Quadro 7 apresenta a pontuação geral da ferramenta IQ COSAN do Serviço de Alimentação Escolar avaliado.

Quadro 7: Pontuação dos componentes da avaliação diária e semanal dos cardápios do SAE.

\begin{tabular}{|c|c|}
\hline $\begin{array}{c}\text { AVALIAÇÃO MENSAL } \\
\text { (cardápio - três semanas) }\end{array}$ & Total \\
\hline Semana 1 & 84,5 \\
\hline Semana 2 & 88,5 \\
\hline Semana 3 & 86,5 \\
\hline Pontuação & 86,5 \\
\hline Classificação & Adequado \\
\hline
\end{tabular}

Assim, a classificação de 86,5 pontos, corresponde ao somatório dos resultados da avaliação diária e semanal, o que indica que o mesmo está adequado aos valores de referência fornecidos pela ferramenta, respeitando a qualidade da segurança alimentar e nutricional.

\section{CONCLUSÕES}

Os resultados encontrados classificam os cardápios oferecidos às crianças do SAE da UEI como adequados. Dessa forma, o IQ COSAN é uma ferramenta nova e de fácil utilização para a análise de cardápios da alimentação escolar que serve de apoio para o nutricionista e demais atores do PNAE poderem verificar se estão oferecendo cardápios saudáveis à população alvo. 


\section{REFERÊNCIAS}

[1] Brasil. Lei no 11.947, de 16 de junho de 2009. Dispõe sobre o atendimento da alimentação escolar e do Programa Dinheiro Direto na Escola. Diário Oficial da União. 2009. Disponível em: <https://www.siteal.iiep.unesco.org/sites/default/files/sit_accion_files/br_0537.pdf>. Acesso em: 30 jul 2020.

[2] Brasil. Resolução no 26, de 17 de junho de 2013. Dispõe sobre o atendimento da alimentação escolar aos alunos da educação básica no âmbito do Programa Nacional de Alimentação Escolar - PNAE. Disponível em: < https://www.fnde.gov.br/index.php/programas/pnae/pnae-sobre-o-programa/pnae-legislacao>. Acesso em $16 \mathrm{dez}$ 2020 .

[3] FNDE - Fundo Nacional de Desenvolvimento da Educação. Manual IQ CONSAN. Ministério da Educação, Brasília, 2018. Disponível em: <http://www.fnde.gov.br/index.php/acessibilidade/item/12142-iq-cosan >. Acesso em: 30 jul 2020.

[4] FNDE - Fundo Nacional de Desenvolvimento da Educação. Histórico do Programa Nacional de Alimentação Escolar. Ministério da Educação, Brasília, 2020. Disponível em: <https://www.fnde.gov.br/index.php/programas/pnae/pnae-sobre-o-programa/pnae-historico>. Acesso em: $16 \mathrm{dez}$ 2020 .

[5] FNDE - Fundo Nacional de Desenvolvimento da Educação. Índice de qualidade da coordenação de segurança alimentar nutricional - IQ COSAN. Ministério da Educação, Brasília, 2020b. Disponível em: <https://www.fnde.gov.br/index.php/programas/pnae/pnae-area-gestores/ferramentas-de-apoio-aonutricionista/item/12142-iq-cosan>. Acesso em: 16 dez 2020.

[6] BARONE, B. et al. Avaliação qualitativa de cardápios da alimentação escolar da rede pública do estado de São Paulo por meio do índice de qualidade da coordenação de segurança alimentar e nutricional. Revista Multidisciplinar da Saúde (RMS), v. 2, n.03, ano 2020, p. 54-66.

[7] GUIMARÃES, E. P. B. et al. Regionalismo presente nos cardápios da alimentação escolar no

[8] município de Campinorte- Goiás. Revista Brasileira de Geografia Médica e da Saúde. Hygeia 15 (31): 95 - 104, Março/2019.

[9] NETA, J. R. da. S. Cardápios escolares: análise segundo o índice de qualidade em segurança alimentar e nutricional. 2019.

[10] MENDES, V. Y. H. F. et al. Avaliação qualitativa de cardápios da alimentação escolar da rede pública do estado de São Paulo por meio do índice de qualidade da coordenação de segurança alimentar e nutricional. Revista Multidisciplinar da Saúde (RMS), 2(3): 54-66, 2020. 


\section{Capítulo 4}

Avaliação da atividade antimicrobiana de peptídeos produzidos por Bacillus amyloliquefaciens P5 e nanoencapsulação visando à inibição de bactérias patogênicas de alimentos

Vinícius dos Santos Ribeiro

Lilian Raquel Hickert

Lúcia Allembrandt da Silva Ries

Patricia da Silva Malheiros

Karla Joseane Perez

Resumo: A utilização de peptídeos antimicrobianos e substâncias do tipo bacteriocinas (BLIS) constituem alternativas para eliminar ou controlar a multiplicação de micro-organismos contaminantes e/ou deteriorantes de alimentos. 0 objetivo do presente estudo, em andamento, é trazer contribuições referentes à segurança e à inocuidade de alimentos através do desenvolvimento de novas tecnologias de conservação com a utilização dessas substâncias antimicrobianas. Assim, empregou-se o Bacillus amyloliquefaciens P5, isolado da puba de mandioca, para a produção destas substâncias com posterior caracterização e purificação parcial e que será seguida do encapsulamento em nanovesículas. Para tal, realizou-se o cultivo em três diferentes meios (caldo BHI, caldo Landy e caldo soro de queijo (CSQ)). Após, com o sobrenadante bruto filtrado $(0,22 \mu \mathrm{m})$ foi verificada a ação antimicrobiana em relação a microorganismos Gram-positivos e Gram-negativos contaminantes de alimentos, através da titulação em Unidades Arbitrárias por mL (UA/mL) seguida da técnica de ágar difusão em BHI sólido. Posteriormente, utilizou-se a técnica de extração das substâncias antimicrobianas no sobrenadante, com isobutanol. Os resultados dos testes de antagonismo mostraram que Listeria monocytogenes ATCC 7644, P. aeruginosa ATCC 27853 (3200 UA/mL), S. Typhimurium e E. faecalis ATCC 29121 demonstraram sensibilidade a(s) substância(s) estudadas. Podemos concluir que, dos meios testados, o caldo BHI foi o que demonstrou melhores resultados, seguido do CSQ e caldo Landy que não apresentou nenhum resultado satisfatório. A estratégia de purificação da(s) substância(s) antimicrobiana através da precipitação com isobutanol demonstrou resultados positivos. Houve um aumento na concentração da substância, nos testes com o caldo BHI, já que o espectro de ação contra L. monocytogenes ATCC 7644 foi maior (3200 UA/mL) comparado aos testes com o sobrenadante bruto filtrado (200 UA/mL). Não foi observado diferença entre os testes com o sobrenadante bruto filtrado e a substância semi-purificada nos tratamentos com CSQ. Pretende-se ainda realizar testes para detecção da atividade antifúngica contra fungos filamentosos. Portanto, os peptídeos produzidos por B. amyloliquefaciens P5 apresentam potencial para inibição de um importante patógeno alimentar, sendo que mais estudos estão sendo realizados para melhorar a ação antimicrobiana dessas substâncias para, no futuro, seguir com o encapsulamento em nanovesículas.

Palavras-chave: peptídeos antimicrobianos; Patógenos alimentares; difusão em ágar; extração com isobutanol. 


\section{INTRODUÇÃO}

A contaminação por micro-organismos em alimentos é um problema tanto econômico para a indústria como também um problema de saúde pública. Neste contexto, a garantia da qualidade e inocuidade destes alimentos é de grande interesse da indústria e a busca por novas e promissoras substâncias inibidoras destes patógenos tem se tornado uma alternativa cada vez mais interessante. As bactérias do gênero Bacillus são reconhecidas como bons produtores de moléculas com atividade antimicrobiana e possuem um histórico de uso seguro na indústria (MOTTA; LORENZINI; BRANDELLI, 2007; PEREZ et al., 2017).

As bacteriocinas correspondem a um grupo heterogêneo de substâncias, que podem ser proteínas ou peptídeos antimicrobianos, sintetizadas no ribossomo de bactérias e secretadas para fora da célula. Geralmente, estas substâncias são inibidoras de cepas intimamente ligadas ao micro-organismo produtor (MOTTA; LORENZINI; BRANDELLI, 2007). No entanto, este conceito vem sendo modificado uma vez que se tem observado a ação de bacteriocinas contra micro-organismos de um grupo filogenético diferente do micro-organismo produtor (BRITTES, 2010).

É comumente aceito na academia que as bacteriocinas causam alterações na permeabilidade das membranas celulares do organismo alvo, causando sua morte, sendo as características anfifílicas das bacteriocinas a chave para essa interação (BRITTES, 2010).

Para estudar e, posteriormente, realizar a aplicação de peptídeos antimicrobianos se faz necessário a purificação parcial ou completa destas substâncias. Como as substâncias diferem em estrutura e peso molecular é muito difícil adotar um único protocolo de purificação. A centrifugação da cultura é geralmente a primeira etapa do processo de purificação e tem o objetivo de separar as células do sobrenadante. É um processo vantajoso porém é obtido uma separação melhor realizando a filtragem do sobrenadante posterior à centrifugação (LEÃS, 2012).

Diversas técnicas são utilizadas a fim de concentrar as substâncias, sendo a precipitação com sulfato de amônio amplamente utilizada (SIRTORI, 2006). Há técnicas que dependem de menos etapas, como a precipitação ácida com HCl (COOPER, et al. , 1981; NAKANO et al., 1988) e também a extração com solventes orgânicos, como a precipitação com butanol (KAWULKA et al., 2004; STEIN, 2008). Estas técnicas, apesar de levarem a preparações de antimicrobianos altamente puros, apresentam o rendimento final baixo. Esses procedimentos funcionam perfeitamente para escalas laboratoriais, no entanto, novas técnicas devem ser estudadas para tornar viável sua utilização em escala semi-industrial. A atividade de bacteriocinas ou BLIS nos alimentos pode ser afetada por diversos fatores, como mudança na sensibilidade e carga eletrostática da bacteriocina, ligação da bacteriocina ao alimento e estas ainda podem sofrer inativação por proteases (SCHULZ et al., 2009). Neste contexto, a incorporação de bacteriocinas em alimentos de forma segura e eficiente se torna um desafio e se faz necessário buscar novas tecnologias que garantam a estabilidade e liberação controlada das bacteriocinas (MALHEIROS et al. 2012).

A nanoencapsulação é uma excelente estratégia para garantir uma menor degradação dos peptídeos antimicrobianos. Apesar de ser uma nova tecnologia, seu uso na indústria alimentícia tem mostrado um enorme potencial em garantir uma melhor dispersão e a liberação controlada das substâncias no alimento (DE CAMPO, 2018).

São utilizados diversos materiais como matriz nanoencapsulante, todos devem ser "Geralmente Reconhecidos como Seguros" (GRAS - Generally Recognized as Safe). As matrizes podem ser de natureza polissacarídica (ANDRÉ, 2019), gomas e mucilagens (DE CAMPO, 2018) ou de natureza lipídica (MALHEIROS et al., 2011). Este trabalho foi apresentado em forma de pôster digital no I Congresso Digital de Nanobiotecnologia e Bioengenharia e foi sugerido pela comissão avaliadora que fosse utilizado materiais biodegradáveis para compor as matrizes da nanocápsulas pois esta alternativa é mais interessante para indústria em questão de custo, já que é possível reutilizar subprodutos da produção de alimentos e também por diminuir o uso de aditivos sintéticos nos alimentos. Independente da escolha do tipo de material nanoencapsulante, a prioridade sempre será materiais que não apresentem nenhum tipo de dano à saúde humana.

É notável que o uso de estratégias para inibição de patógenos representa um campo promissor na indústria alimentícia e sempre se faz necessário o uso de novos métodos para garantir a estabilidade e o controle da liberação destas substâncias. A nanotecnologia é uma ferramenta com um potencial uso na indústria alimentícia, garantindo a proteção de substâncias bioativas e seu controle de liberação, permitindo assim um incremento na vida útil dos produtos (UTENG et al., 2002; MALHEIROS et al. 2012). 
O objetivo do presente estudo, em andamento, é contribuir com a qualidade e inocuidade dos alimentos através da investigação de novas substâncias inibitórias, de modo a purificar e caracterizar peptídeos antimicrobianos produzidos por B. amyloliquefaciens P5 seguido do encapsulamento da substância em nanovesículas a fim de testar-se, futuramente, a aplicação direta desta substância purificada ou semipurificada em diferentes matrizes alimentares.

\section{MATERIAL E MÉTODOS}

\subsection{PRODUÇÃO DA(S) SUBSTÂNCIA(S) ANTIMICROBIANA(S)}

As colônias de Bacillus amyloliquefaciens P5 foram reativadas em ágar Infusão de Cérebro e Coração (Brain Heart Infusion - BHI) sólido e coletadas por raspagem e, após, transferidas para frasco Erlenmeyer de 125 $\mathrm{mL}$ contendo $20 \mathrm{~mL}$ de caldo BHI. Após, este frasco que caracteriza o pré-inoculo, foi incubado a $37^{\circ} \mathrm{C}$ por 24 h, em incubadora com agitação orbital - shaker (125 rpm).

Para o inóculo, transferiu-se uma alíquota de $1 \%(\mathrm{v} / \mathrm{v})$ do pré-inóculo para frascos Erlenmeyer de $500 \mathrm{~mL}$ contendo $200 \mathrm{~mL}$ de caldo BHI, caldo CSQ (TECH, 2019) e caldo Landy (PEREZ, 2014). A cultura foi

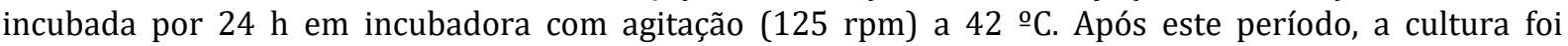
centrifugada durante $15 \mathrm{~min}$. a $10.000 \mathrm{~g} 4{ }^{\circ} \mathrm{C}$ e o sobrenadante foi esterilizado por filtração através de filtros de celulose com porosidade de 0,22 $\mu \mathrm{m}$ acoplados a seringas. Os filtrados foram conservados em geladeira a $4{ }^{\circ} \mathrm{C}$ até utilização, por um período máximo de 7 dias. Este processo constitui a primeira etapa de purificação, obtendo-se assim a substância parcialmente purificada (sobrenadante bruto e filtrado) (PEREZ et al., 2017).

\subsection{TITULAÇÃO ANTIMICROBIANA DO SOBRENADANTE BRUTO}

Utilizou-se o método da diluição seriada para determinar o número de unidades arbitrárias por $\mathrm{mL}$ (UA/mL) no sobrenadante bruto, ou seja, a atividade antimicrobiana contra determinado microorganismo. Para isto, após a obtenção do sobrenadante bruto filtrado os mesmos foram diluídos sucessivamente em placas de microtitulação a partir da proporção 1:1 (v/v) em solução fisiológica esterilizada ( $\mathrm{NaCl}$ 0,85\%). Procedeu-se então com o teste de ágar-difusão onde alíquotas de $20 \mu \mathrm{L}$ dessas diluições foram inoculadas diretamente na forma de um "spot" na superfície de placas contendo ágar BHI com uma suspensão de $10^{8}$ células/mL espalhadas (padronizadas em espectrofotômetro no intervalo de 0,08 a $0,15 \mathrm{~nm}$ ) em solução fisiológica esterilizada ( $\mathrm{NaCl}$ 0,85\%) dos micro-organismos indicadores. As placas foram incubadas a $37^{\circ} \mathrm{C}$ por $24 \mathrm{~h}$ e o título designado como UA/mL foi definido como sendo a recíproca da última diluição que apresentou halo de inibição (KIMURA et al., 1998).

Em seguida, a atividade antibacteriana foi calculada e expressa em unidades arbitrárias (UA/mL) empregando-se a equação: "UA = título.1000 $(\mu \mathrm{L}) \cdot \mathrm{v}^{-1}(\mu \mathrm{L})$ " sendo o " $\mathrm{v}$ " o volume do extrato utilizado no ensaio (BATDORJ et al., 2006), de $20 \mu \mathrm{L}$. Os ensaios contra as bactérias Gram-negativas foram realizados adicionando-se $10 \mu \mathrm{L}$ de EDTA 5M aos poços da placa de diluição, misturando-se com o sobrenadante bruto filtrado. Todos os testes foram realizados em duplicata.

Tabela 1: Micro-organismos indicadores de atividade antimicrobiana.

\begin{tabular}{|l|c|}
\multicolumn{1}{c|}{$\begin{array}{c}\text { Micro-organismos indicadores } \\
\text { Gram-positivos }\end{array}$} & Fonte \\
\hline Listeria monocytogenes & ATCC 7644 \\
\hline Staphylococcus aureus & Isolado clínico \\
\hline Bacillus cereus & ATCC 14579 \\
\hline Gram-negativos & \\
\hline $\begin{array}{l}\text { Pseudomonas aeruginosa } \\
\text { Enterococcus faecalis } \\
\text { Salmonella enterica Typhimurium }\end{array}$ & ATCC 27853 \\
\hline
\end{tabular}

Fonte: Autores, 2020. 


\subsection{EXTRAÇÃO COM ISO-BUTANOL DO SOBRENADANTE DA CULTURA}

A bactéria produtora Bacillus amyloliquefaciens P5 foi incubada por $24 \mathrm{~h}$ a $37 \stackrel{\text { o }}{\mathrm{C}}$ em caldo BHI (préinóculo). Então, preparou-se o inóculo a 1\% em caldo BHI, CSQ e Landy e estes foram incubados a $37 \stackrel{\circ}{\circ} \mathrm{C}$ por $24 \mathrm{~h}$ a $125 \mathrm{rpm}$ (PEREZ et al., 2017). Após, centrifugou-se o caldo de cultura com o crescimento bacteriano a $10.000 \mathrm{~g}$, por 10-15 min. a $4 \stackrel{\circ}{\circ}$. Em seguida, filtrou-se os sobrenadantes em um sistema de filtragem a vácuo com membranas de celulose $(0,22 \mu \mathrm{m})$ e adicionou-se $1 / 4$ do volume de isobutanol, deixando-se em agitação por $1 \mathrm{~h}$ (agitador magnético em capela de exaustão química). Transferiu-se, então, as misturas para funis de separação e as mesmas foram deixadas em temperatura ambiente "overnight". Posteriormente, a fase orgânica (superior) foi transferida para placas de petri e deixadas a temperatura de $37 \stackrel{\circ}{\circ}$ overnight. Os resíduos foram suspensos adicionando-se $10 \mathrm{~mL}$ de metanol. Em seguida, a fim de verificar se houve um aumento na atividade antimicrobiana, realizou-se um novo teste de antagonismo, como descrito no item 2.2. As suspensões que não foram utilizadas foram armazenadas em freezer a $-22^{\circ} \mathrm{C}$.

\section{RESULTADOS E DISCUSSÃO}

\subsection{ATIVIDADE ANTIMICROBIANA}

Os resultados dos testes de antagonismo mostraram que Listeria monocytogenes ATCC 7644 apresentou sensibilidade a(s) substância(s) estudadas, como mostra a figura (1). Podemos observar que, dos meios testados, o caldo BHI foi o que demonstrou melhores resultados (400 UA/mL), seguido do CSQ (100 $\mathrm{UA} / \mathrm{mL}$ ) e caldo Landy que não apresentou nenhum resultado satisfatório, como mostra a figura (2).

Os testes de antagonismo utilizando EDTA como agente quelante contra bactérias Gram-negativas apresentaram resultados satisfatórios contra os micro-organismos testados, com os seguintes resultados: Caldo BHI - P. aeruginosa ATCC 27853 (3200 UA/mL), S. Typhimurium (3200 UA/mL) e E. faecalis ATCC 29121 (800 UA/mL). CSQ - P. aeruginosa ATCC 27853 (800 UA/mL), S. Typhimurium (1600 UA/ mL) e $E$. faecalis ATCC 29121 (3200 UA/mL), como representado na figura (3). No entanto, é incerto afirmar se esta sensibilidade apresentada é devido a ação da substância ou a concentração do EDTA (5M). Será necessário realizar mais testes com concentrações diferentes de EDTA para se obter resultados mais consistentes.

Figura 1: Resultados das atividades antimicrobianas de B. amyloliquefaciens P5 inoculadas diretamente sobre ágar BHI contendo Listeria monocytogenes ATCC 7644. Em (A) atividades provenientes do sobrenadante bruto de caldo BHI (400 UA/mL). Em (B) de Caldo Soro de Queijo - CSQ (100 UA/mL).

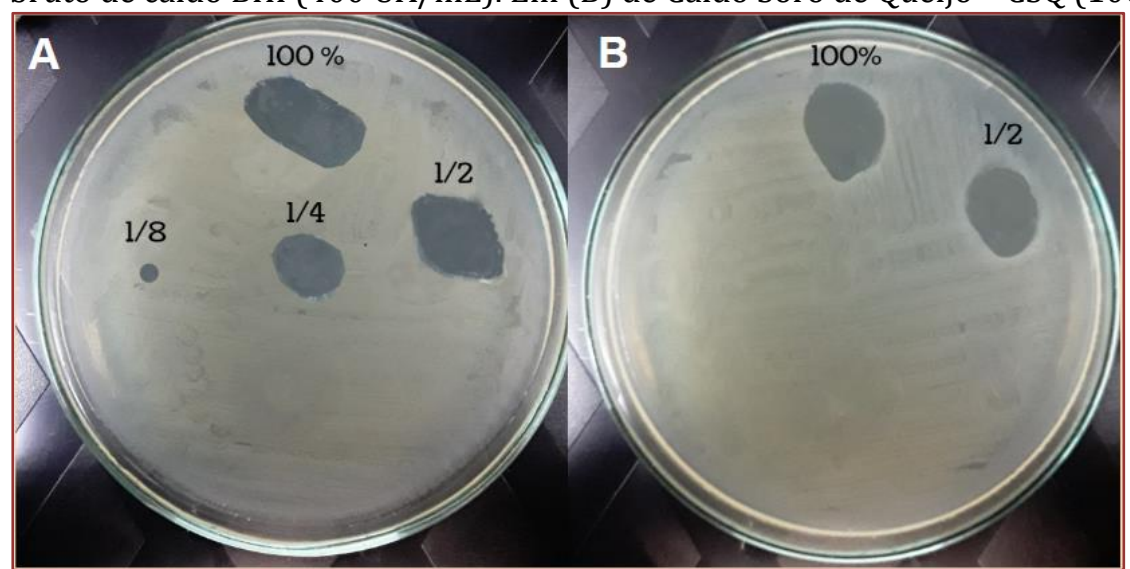

Fonte: Autores, 2019. 
Figura 2: Atividade antibacteriana contra Listeria monocytogenes ATCC 7644 de sobrenadante de $B$. amyloliquefaciens $\mathrm{P} 5$ cultivado em meio BHI e CSQ.

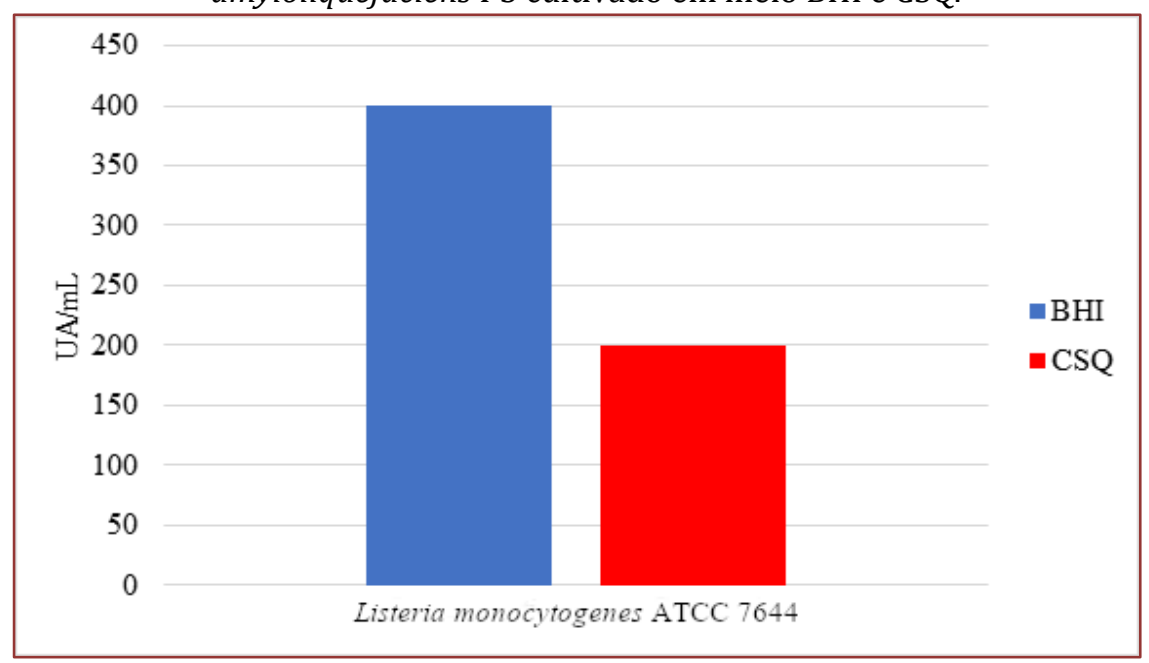

Fonte: Autores, 2020.

Figura 3: Atividade antibacteriana contra micro-organismos Gram-negativos de sobrenadante de $B$. amyloliquefaciens P5 + EDTA 5M cultivados em meio BHI e CSQ.

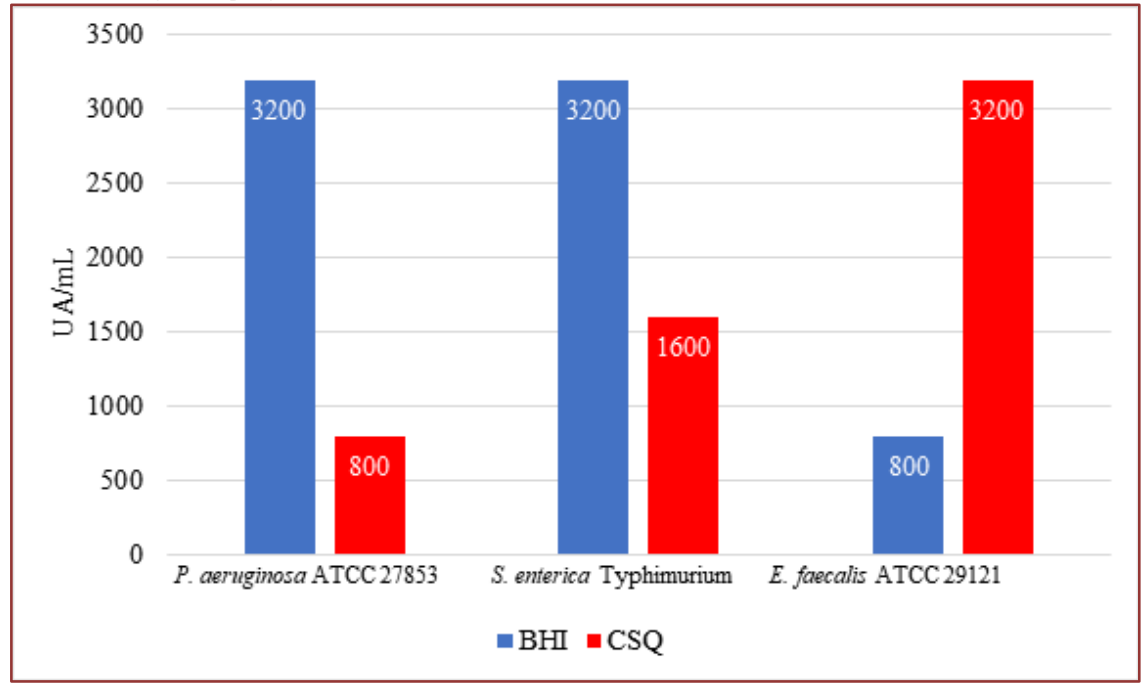

Fonte: Autores, 2019.

\subsection{EXTRAÇÃO COM ISOBUTANOL}

A extração com isobutanol apresentou resultados satisfatórios apresentando a formação de um precipitado na fase superior para os três meios testados. No entanto, nem todo o precipitado é formado por bacteriocinas já que existem outras substâncias no sobrenadante. A extração com isobutanol se mostrou uma técnica eficiente e uma boa estratégia para concentração da(s) substância(s). Nos testes de antagonismo realizados com a substância semi-purificada foi observado um aumento significativo se comparada à substância bruta filtrada. Novamente, apenas L. monocytogenes apresentou sensibilidade (3200 UA/mL), o aumento da concentração foi apenas observado para o caldo BHI e para o CSQ (100 $\mathrm{UA} / \mathrm{mL}$ ) não foi observada diferença significativa, como mostram as Figuras (4C e D). 
Figura 4: Em (C) atividades antimicrobianas da substância semi-purificada (caldo BHI - 3200 UA/mL) de B. amyloliquefaciens P5 inoculadas em ágar BHI contendo L. monocytogenes ATCC 7644 e em (D) proveniente da substância semi-purificada de CSQ (100 UA/mL).

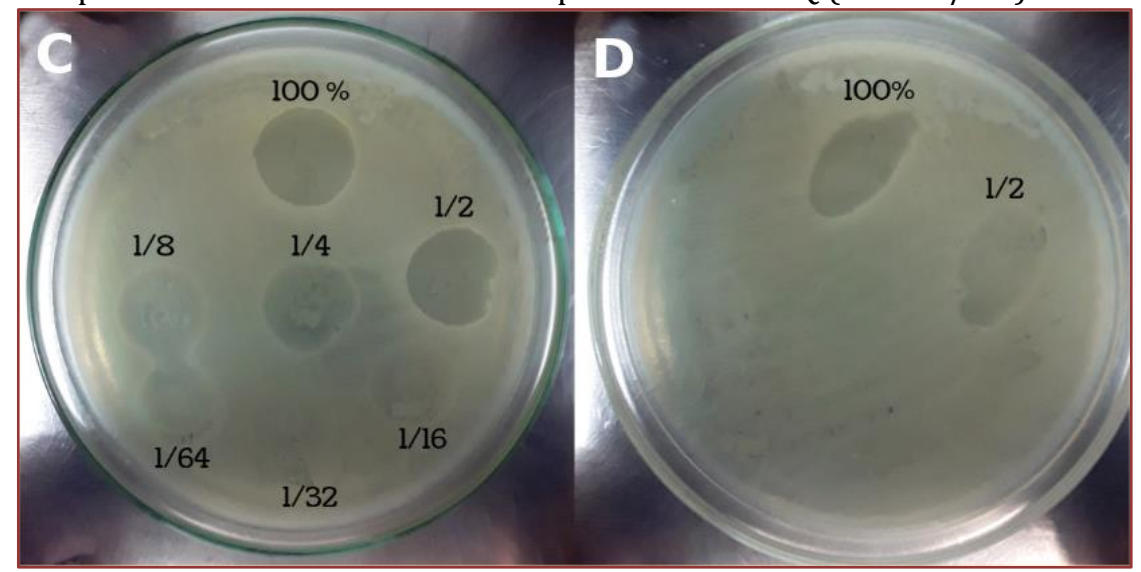

Fonte: Autores, 2019.

\section{CONCLUSÃO}

Os resultados dos testes de antagonismo mostraram que Listeria monocytogenes ATCC 7644 demonstrou sensibilidade a(s) substância(s) estudadas. Podemos concluir que, dos meios testados, o caldo BHI foi o que apresentou melhores resultados, seguido do CSQ e caldo Landy que não apresentou nenhum resultado satisfatório. Os micro-organismos Gram-negativos testados apresentaram sensibilidade, no entanto, é incerto afirmar se a sensibilidade é devido a(s) substância(s) ou ao EDTA de modo que mais testes devem ser realizados com diferentes concentrações de EDTA. Podemos afirmar também que a estratégia de purificação da substância antimicrobiana escolhida foi um sucesso com o caldo BHI, já que o espectro de ação foi maior (3200 UA/mL) comparado aos testes com o sobrenadante bruto filtrado (400 UA/mL). Não foi observada diferença entre os testes com o sobrenadante bruto filtrado e a substância semi-purificada nos tratamentos com CSQ. Pretende-se ainda realizar testes para detecção da atividade antifúngica para fim de verificar o espectro de ação da(s) substância(s). Além disso, espera-se seguir para o encapsulamento da substância semi-purificada em nanovesículas, sendo que atualmente estamos pesquisando quais os melhores materiais para compor a matriz nanoencapsulante.

\section{REFERÊNCIAS}

1. ANDRÉ, W.P.P. Atividade anti-helmíntica de nanopartículas polissacarídicas de acetato de carvacrila sobre nematoides gastrintestinais de ovinos. Tese (Doutorado) - Universidade Estadual do Ceará, Fortaleza, 2019.

2. BATDORJ, B. et al. Purification and characterization of two bacteriocins produced by lactic acid bacteria isolated from Mongolian airag. Journal of Applied Microbiology, v. 101, n. 4, p. 837-48, 2006.

3. COOPER, D. G. et al. Enhanced production of surfactin fromBacillus subtilis by continuous product removal and metal cation additions. Applied and Environmental Microbiology, v. 42, n. 3, p. 408-412, 1981.

4. DE CAMPO, C. Nanoencapsulamento de óleo de chia e zeaxantina utilizando mucilagens como material estruturante: desenvolvimento, caracterização e aplicação. Tese (Doutorado) - UFRGS, Porto Alegre, p. 37-42, 2018.

5. KAWULKA, K.E. et al. Structure of subtilosin A, a cyclic antimicrobial peptide from Bacillus subtilis with unusual sulfur toalpha-carbon cross-links: formation and reduction of alpha-thio-alphaamino acid derivatives. Biochemistry, 43, n. 12, p. 3385-3395, 2004.

6. KIMURA, H. et al. Novel bacteriocina of Pediococcus sp. ISK-1 isolated from well aged bed of fermented rice bran. Annals of New York Academy of Science, v. 864, p. 345-348, 1998.

7. LEÃES, Fernanda Leal. Produção de peptídeos antimicrobianos produzidos por Bacillus sp. P 11. Tese (Doutorado) - UFRGS, Porto Alegre, p. 10-25, 2012.

8. MALHEIROS, P. et al. Antilisterial activity and stability of nanovesicle-encapsulated antimicrobial peptide P34 in milk. Food Control, v. 23, p. 42 - 47, 2012.

9. MALHEIROS, P.S. et al. Nanovesicle encapsulation of antimicrobial peptide P34: physicochemical characterization and mode of action on Listeria monocytogenes. Journal of Nanoparticle Research, v.13, p.3545 - 3552, 2011. 
10. MOTTA, A. S. et al. Purification and Partial Characterization of an Antimicrobial Peptide Produced by a Novel Bacillus sp. Isolated from the Amazon Basin., Vol. 54, p. 282-286, 2007.

11. NAKANO, M.M. et al. Identification of a genetic locus required for biosynthesis of the lipopeptide antibiotic surfactin in Bacillus subtilis. Journal of Bacteriology, p.5662-5668, 1988.

12. PEREZ, K. J. Caracterização de lipopeptídeos antimicrobianos e surfactantes produzidos por Bacillus spp. isolados de puba. Tese (Doutorado) - UFMG, Belo Horizonte, p. 76-77, 83-86, 93-95, 2014.

13. PEREZ, K. J. et al. Bacillus spp. Isolated from Puba as a Source of Biosurfactants and Antimicrobial Lipopeptides. Frontiers in Microbiology. v. 8. n. 61, 2017.

14. SCHULZ, D. et al. Bacteriocinas: Mecanismo de ação e uso na conservação de alimentos. Alim. Nutr., Araraquara, v.14, n.2, p. 229-235, 2003.

15. SIRTORI, L. R. et al. Purification and partial characterization of an antimicrobial peptide produced by Bacillus sp. strain P45, a bacterium from the Amazon basin fish Piaractus mesopotamicus. Journal of General and Applied Microbiology, v. 52, p. 357-363. 2006.

16. STEIN, T. Whole-cell matrix-assisted laser desorption/ionization mass spectrometry for rapid identification of bacteriocin/lantibiotic-producing bacteria. Rapid Communications in Mass Spectrometry, v. 22, p. 1146-1152, 2008.

17. TECH, Bárbara Iegli. Avaliação da produção de biossurfactantes por Bacillus megateruim e B. amyloliquefaciens P5 a partir do soro de queijo. 2019. Monografia (Graduação) - Curso de Graduação em Engenharia de Bioprocessos e Biotecnologia - Universidade Estadual do Rio Grande do Sul, Novo Hamburgo, 2020.

18. UTANG, M. et. al. Rapid Two-Step Procedure for Large-Scale Purification of Pediocin-Like Bacteriocins and Other Cationic Antimicrobial Peptides from Complex Culture Medium. Applied and Environmental Microbiology. Vol. 68, No. 2 , p. 952-956, 2002. 


\section{Capítulo 5}

Eficácia microbiana e parasitária de sanitizantes à base de cloro e ácido acético em alface (Lactuca Sativa L.)

\section{Eveline Ferreira Soares}

\section{Juliana de Mello Silva}

Vilmar Antônio Boff

\section{Gerônimo Rodrigues Prado}

Resumo: Objetivou-se avaliar a eficácia antimicrobiana e parasitária dos sanitizantes à base de hipoclorito e ácido acético em alface e avaliar o tempo de exposição para eliminação destas populações. Cinco amostras foram coletadas no município de Cruz Alta, RS. As amostras foram divididas em três tratamentos: controle, hipoclorito de sódio e ácido acético preparados com uma diluição de 1:100 (1\%) e em tempos de exposição de 5, 10, 15 e 20 minutos. Para avaliação parasitológica foi realizada análise do sedimento no microscópio óptico com aumento 10x e 40x. A redução da carga microbiana e parasitária para níveis aceitáveis comprovam a eficácia das soluções de hipoclorito ( $1 \%$ de cloro ativo) como agente sanitizante respeitado o tempo de 20 minutos de imersão das folhas. Também ficou demonstrada a redução do número de colônias e indivíduos parasitários na solução com ácido acético (vinagre), porém com eficácia inferior quando comparada ao hipoclorito de sódio.

Palavras-Chave: hipoclorito de sódio; ácido acético; carga microbiana; parasitas. 


\section{INTRODUÇÃO}

A lavagem dos vegetais é a prática mais comumente usada na obtenção de um produto mais seguro. É fundamental que a água seja de boa qualidade, contudo, a eficácia dos processos de lavagem pode ser aumentada quando utilizado soluções sanitizantes na água, reduzindo consideravelmente o número de microrganismos presentes nestes alimentos (Frank; Takeushi, 1999). A sanitização tem função significativa na minimização da deterioração e na conservação da qualidade do produto (Brackett; Splittstoesser, 1992). Portanto, o presente estudo trouxe uma proposta de avaliar a eficácia antimicrobiana e parasitária dos sanitizantes hipoclorito e ácido acético em alface (Lactuca sativa $L$.) e avaliar o tempo de exposição destes agentes para eliminação destas populações.

\section{MATERIAL E MÉTODOS}

\subsection{AVALIAÇÃO DA EFICÁCIA ANTIMICROBIANA DOS SANITIZANTES EM ALFACE}

Para avaliar a eficácia dos sanitizantes foram compradas cinco amostras (pé de alface) de variedade crespa em um supermercado no município de Cruz Alta/RS. As amostras em seu respectivo invólucro foram encaminhadas ao Laboratório da Universidade Estadual do Rio Grande do Sul, unidade em Cruz Alta.

No laboratório, todas as amostras foram retiradas da embalagem. Cada amostra de alface foi acondicionada em bandejas tamanho $(40 \times 60 \times 8 \mathrm{~cm})$. Nas bandejas, foi removido das amostras a matéria orgânica e solo residual das folhas e raízes. Para tal ação utilizou-se água destilada e esterilizada. Além disso, foram removidas as folhas que apresentavam deterioração e as partes impróprias para consumo.

Posteriormente, as folhas de cada pé de alface foram fragmentadas e 30 gramas foram pesadas, para cada amostra. As amostras foram subdivididas em quatro tempos diferentes: 5, 10, 15 e 20 minutos e acondicionadas em três soluções distintas, sendo: controle (amostra não higienizada), hipoclorito 1\%, ácido acético 1\%. A solução de hipoclorito de sódio foi preparada com uma proporção de $990 \mathrm{~mL}$ de água destilada estéril para $10 \mathrm{~mL}$ de hipoclorito de sódio em uma diluição de 1:100 (1\%). A concentração de cloro ativo do produto comercial utilizado foi de 2,5\%. A solução de lavagem com ácido acético foi preparada nas mesmas proporções. 0 vinagre comercial utilizado contava com teor de $4 \%$ de ácido acético. Todas as soluções foram preparadas em copos de béquer de vidro de $1000 \mathrm{~mL}$.

\subsection{AVALIAÇÃO DO TEMPO DE EXPOSIÇÃO NA ELIMINAÇÃO DA POPULAÇÃO MICROBIANA DAS ALFACES}

As amostras de alface foram submersas em seus respectivos tratamentos sanitizantes em tempos de exposição de 5, 10, 15 e 20 minutos. Posterior ao tempo de exposição nos tratamentos, as folhas de alface foram retiradas dos copos de béquer. Um swab estéril fora friccionado nas folhas de alface e posteriormente semeado em placas de petri contendo Ágar Macconkey, através do método spread plated (Tortora et al., 2016). Para as análises dos microrganismos foram feitas as diluições das amostras, adicionando o volume de diluente água peptonada $0,1 \%$ para diluição inicial desejada, de 1:1, ou seja, 1,0 $\mathrm{mL}$ de diluente por grama de amostra, de forma que cada mililitro do lavado correspondesse a um grama de amostra. Após a semeadura em placa, estas foram acondicionadas em estufas a $36^{\circ} \mathrm{C}$ por 48 horas. Posteriormente, realizou-se a contagem das placas multiplicando o número de colônias pela diluição correspondente, obtendo-se unidades formadoras de colônias UFC por grama de alface (UFC/g).

\subsection{AVALIAÇÃO DA AÇÃo DOS AGENTES SANITIZANTES NA ELIMINAÇÃO PARASITÁRIA NAS FOLHAS DE ALFACE}

A avaliação parasitária ocorreu conforme metodologia descrita em Nascimento (2014). Para a avaliação parasitológica retirou-se $200 \mathrm{~mL}$ da água de cada copo de béquer onde foram depositados 30 gramas de alface. As amostras numeradas de 1 a 5, aleatoriamente, foram avaliadas após 20 minutos de exposição na amostra controle, isto é, lavagem somente com água, e nas lavagens com os sanitizantes hipoclorito de sódio e ácido acético A água retirada foi filtrada com o auxílio de um tamis preparado com 4 dobras de gaze. Em seguida, mantida em repouso por $24 \mathrm{~h} \pm 2$, para sedimentação. Passado este período, o sobrenadante fora desprezado mantendo-se aproximadamente $24 \mathrm{~mL}$ em cada cálice cônico, em seguida, esse volume foi fracionado em dois tubos cônicos tipo falcon, cada um contendo $12 \mathrm{~mL}$. Após essa etapa, 
os conteúdos dos tubos foram centrifugados a $1015 \mathrm{~g}$, durante 5 minutos, e um tubo foi usado para o método de Faust - método de Centrífugo Flutuação (Neves, 2000). E o outro para a o método de Hoffman, Pons e Janer - HPJ (Neves, 2000). Para o método de Faust, após a centrifugação inicial de 5 minutos, desprezou-se o sobrenadante do tubo falcon e resuspendeu-se o precipitado com solução de sulfato de zinco a 33\%, em seguida uma nova centrifugação foi realizada com mesma rotação durante 2 minutos, observando-se a formação de uma película sobrenadante. Tanto para o método de Hoffman, Pons e Janer (HPJ), quanto para o método de Faust, pipetou-se $50 \mu \mathrm{L}$ do precipitado, adicionando-o a uma lâmina, contendo igual volume de lugol a $0,5 \%$, sobrepondo-a com uma lamínula e, em seguida, procedeu-se a análise das estruturas parasitárias em microscópio nas objetivas de 100x e 400x.

\section{RESULTADOS E DISCUSSÕES}

\subsection{AVALIAÇ̃̃O DA EFICÁCIA ANTIMICROBIANA DOS SANITIZANTES EM ALFACE}

Os resultados apontam uma diminuição do crescimento microbiano ao longo do tempo sob efeito dos sanitizantes ácido acético 1\% e hipoclorito de sódio 1\% que podem ser visualizados na Figura 1.

Figura 1 - Eficácia antimicrobiana dos sanitizantes em alface

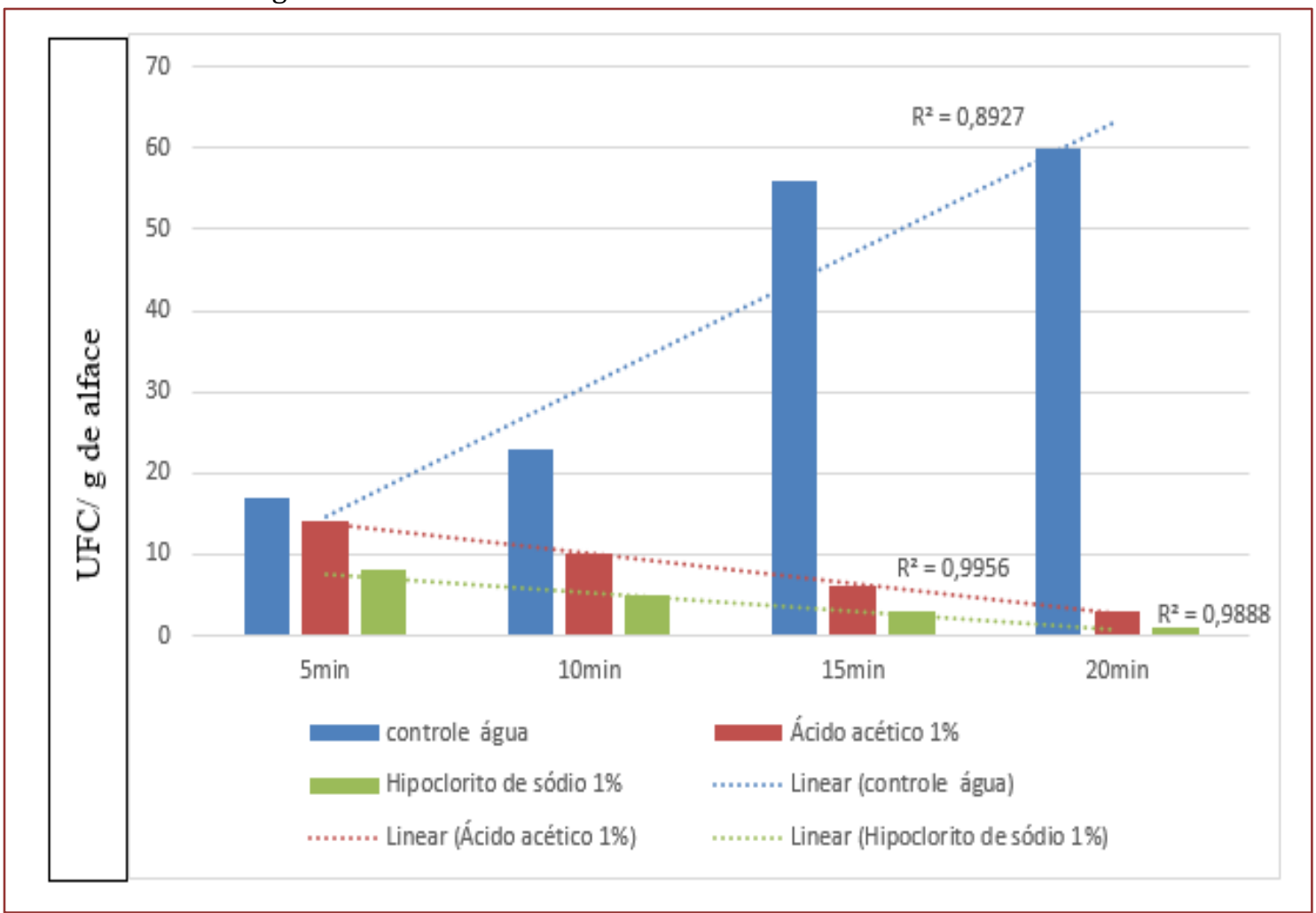

Fonte: Autores (2019)

Os resultados apontam que com o aumento do tempo $(5,10,15,20 \mathrm{~min})$ houve uma elevação do crescimento microbiano no tratamento controle (somente água) conforme mostra a Figura 2. No entanto, observa-se diminuição do número de microrganismos em todos os tempos nos tratamentos com aplicação de ácido acético e hipoclorito de sódio. Após a utilização do hipoclorito de sódio percebeu-se que ao final de 20 minutos, restou apenas 1 (uma) unidade formadora de colônia (UFC/ folha de alface) na placa de petri. Conforme estudo de Ferreira et al. (2011) sobre a eficácia de sanitização de alface com hipoclorito de sódio, na faixa de 2 a 2,5\%, por 15 min e posterior enxágue em água corrente, houve redução da carga microbiana quando comparada às amostras que não foram submetidas a nenhum processo de higienização. Nos resultados observados por Santos (2012), imergir as folhas de alface por 15 minutos em solução de água sanitária a $200 \mathrm{ppm}$ de cloro foi suficiente para reduzir significativamente $(\mathrm{p}<0,05)$ a carga de bactérias heterotróficas, de coliformes termotolerantes e de Escherichia coli, o que corrobora com os resultados encontrados no presente trabalho. 
Figura 2 - Tratamento controle com 5 e 10 minutos de exposição

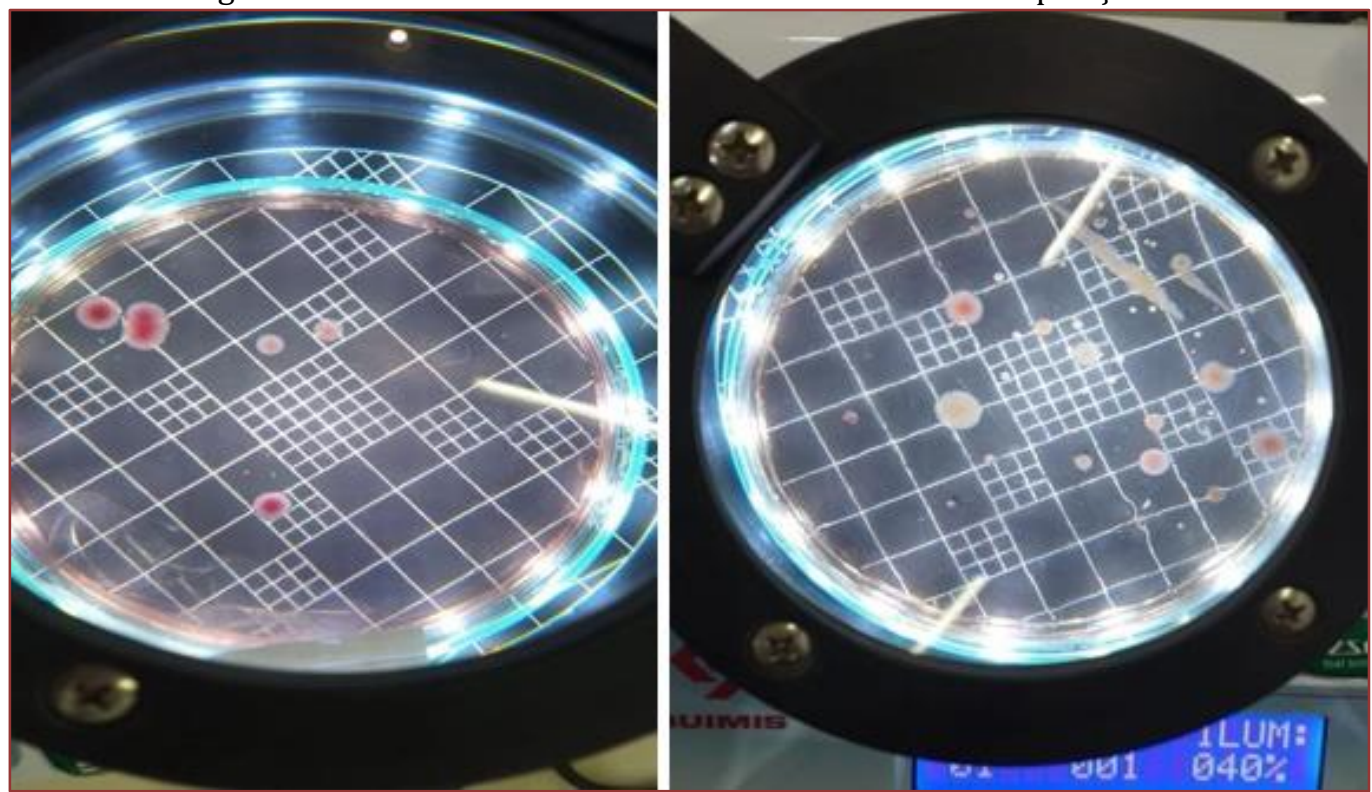

Fonte: Autores (2019)

Apesar do vinagre ser adotado como uma alternativa de baixo custo para a higienização de folhosas em restaurantes, os resultados do presente estudo não permitem recomendar este protocolo, visto que o tratamento onde foi aplicado o ácido acético mesmo com a redução de microrganismos ao longo do tempo, não garantiu a redução dessas populações até níveis satisfatórios, observando-se 4 (quatro) unidades formadoras de colônias ao final de 20 minutos de exposição da alface. Oliveira (2005) salienta que o vinagre em concentração mais elevada $20 \%$ tem permitido que porcentagens de redução mais próximas ao hipoclorito de sódio sejam alcançadas, porém, na presença de coliformes termotolerantes o vinagre não garante a redução total dessas populações. O Centro de Vigilância Sanitária ressalta com relação ao vinagre na sanitização de verduras cruas, que o mesmo é oficialmente registrado e avaliado laboratorialmente como "condimento" pelo Ministério da Agricultura Pecuária e Abastecimento (MAPA), não constando como produto sanitizante. Mesmo com essa avaliação, a acidez do vinagre age positivamente contra os microrganismos patogênicos (Brasil, 1993).

Embora não haja um padrão estabelecido para coliformes totais em hortaliças, os valores encontrados na amostra de alface (controle), ou seja, após lavagem, apenas em água, foi superior daquele encontrado na água de lavagem com vinagre e hipoclorito de sódio, um indicativo de que o procedimento de lavagem é prática ineficiente para a remoção segura de microrganismos presentes em hortaliças, e que do ponto de vista microbiológico é desaconselhável o consumo de alface apenas higienizada com água.

\subsection{AVALIAÇÃO DA AÇÃO DOS SANITIZANTES NA ELIMINAÇÃO DE PARASITAS NAS FOLHAS DE ALFACE}

São considerados parasitas em hortaliças os organismos provenientes principalmente de protozoários, nematoides e platelmintos. No presente trabalho focou-se na presença de nematoides nas amostras, entretanto, as espécies não foram identificadas. Apenas avaliou-se a presença e ausência destes organismos. A Tabela 1 mostra os resultados significativos da avaliação da eficiência dos sanitizantes em parasitas, que foram obtidos após 20 minutos de exposição. 
Tabela 1 - Avaliação da eficiência dos sanitizantes em parasitas

\begin{tabular}{|c|c|c|c|}
\hline \multirow{3}{*}{$\begin{array}{l}\text { "Pé de } \\
\text { alface" }\end{array}$} & \multicolumn{3}{|c|}{$\begin{array}{c}\text { Presença de Parasitas após exposição aos } \\
\text { tratamentos }\end{array}$} \\
\hline & $\begin{array}{l}\text { Controle } \\
\text { água }\end{array}$ & $\begin{array}{l}\text { Hipocloritc } \\
\text { de Sódio 10 }\end{array}$ & $\begin{array}{c}\text { Ácido acético } \\
1 \%\end{array}$ \\
\hline & $\begin{array}{l}\text { Número de } \\
\text { indivíduos }\end{array}$ & \multicolumn{2}{|c|}{ Eficiência de redução em 20 min } \\
\hline Amostra 1 & 6 & $100 \%$ & $66 \%$ \\
\hline Amostra 2 & 6 & $100 \%$ & $50 \%$ \\
\hline Amostra 3 & 5 & $100 \%$ & $60 \%$ \\
\hline Amostra 4 & 4 & $100 \%$ & $75 \%$ \\
\hline Amostra 5 & 4 & $100 \%$ & $75 \%$ \\
\hline Média & 5 & $100 \%$ & $65,2 \%$ \\
\hline
\end{tabular}

Fonte: Autores (2019)

A média de indivíduos observados nas amostras foi de 5 organismos. Observou-se a partir dos dados obtidos que o hipoclorito de sódio foi eficiente na eliminação de $100 \%$ dos indivíduos. Entretanto, quando fora aplicado ácido acético, verificou-se que a média de organismos eliminados foi 65,2\%. A contaminação por nematoides em verduras é muito comum, principalmente naquelas desenvolvidas em sistema convencional de cultivo que é o solo.

A resistência ao ácido acético pode estar associada à fisiologia de alguns parasitas, associada a mecanismos de resistência, em função disso podem afetar decisivamente a ação antimicrobiana dos agentes sanitizantes.

Estudos realizados por Reis (2012) demonstram que, embora achados parasitas em sete amostras de hortaliças, a taxa de contaminação é pequena e satisfatória, mostrando que a maioria das hortaliças não apresenta contaminantes e não oferecem risco ao homem. Mesmo com a pequena taxa de contaminação, existe o risco de infecção quando as hortaliças com parasitas forem ingeridas. Por isso, existe a grande importância da boa higienização através da lavagem preconizada pelo Ministério da Saúde.

\section{CONCLUSÃO}

É possível concluir que a contagem de microrganismos na amostra controle, ou seja, depois da lavagem das folhas de alface com água, mostrou a necessidade e importância da sanitização, de forma a tornar o produto apto para consumo.

A redução da carga microbiana nas folhas de alface para níveis aceitáveis, constatada neste trabalho, comprovam a eficácia das soluções de água sanitária (1\% de cloro ativo) como agente sanitizante de folhas de alface (Lactuca sativa L.), respeitado o tempo de 20 minutos de imersão das folhas. Também ficou demonstrada a redução do número de colônias, a níveis satisfatórios, tanto nas folhas de alface tratadas com solução clorada (água sanitária), quanto com solução com ácido acético (vinagre), todavia, com vantagem para a primeira. Contudo, a redução observada nas contagens microbianas não pode ser atribuída exclusivamente à atividade germicida do agente sanitizante, tendo que considerar que o efeito pode estar conjugado a uma remoção das células na lavagem inicial, sendo esta de boa qualidade.

Com relação à contaminação parasitária, o hipoclorito de sódio foi eficiente na eliminação de 100\% dos indivíduos. Entretanto, quando aplicado ácido acético, observou-se que a média de organismos eliminados foi 65,2\%. A eficácia do hipoclorito como sanitizante é comprovadamente discutida em trabalhos acadêmicos, no entanto, o uso do vinagre ainda precisa de mais estudos e fundamentação científica para ser utilizado como agente saneante. 


\section{REFERÊNCIAS}

[1] Brackett, R. E. \& Splittstoesser, D. F. Fruits and. vegetables. In: Vanderzant, C., Splittstoesser, D. F. (1992). Compendium for the Microbiological Examination of Foods. Washington DC: American Public Health Association. 3rd ed.

[2] Brasil. Ministério da Saúde (1993). Parecer Técnico da coordenação dos laboratórios do Ministério da Saúde sobre uso de vinagre para desinfecção. (Comunicado CVS 64 de 19/05/1993 - DOE de 20/05/1993). Secretária de Vigilância em Saúde. Centro de Vigilância Sanitária.

[3] Ferreira, J. A.; Nenê, A. R. M.; Massulo A. O.; Salamoni, R. M.; Cardoso F. N. (2011). Estudo preliminar da eficácia de sanitização de amostras de alface comercializadas em Campo Grande - MS. (Anuário da Produção Acadêmica Docente).

[4] Frank, J. F.; Takeushi K. (1999). Direct observation of Escherichia coli 0157:H7 inactivation on lettuce leaf using confocal scanning laser microscopy. In: Tuijtelaars (eds) Food Microbiology and Food safety into the next millenium. Proceedings of 17 th International Conference of International Committee on Food Microbiology and Hygiene (ICFMH). Vendhoven. The Netherlands.

[5] Nascimento, E. D.; Alencar, F. L. S. (2014). Antimicrobial and antiparasitic efficiency of desinfectants in the sanitation of vegetables in Natal city - RN. Ciência e Natura, Santa Maria - RS. Revista do Centro de Ciências Naturais e Exatas. Universidade Federal de Santa Maria. v. 36 n. 2 mai-ago. p. 92-106

[6] Neves, D. P. (2000). Parasitologia Humana. São Paulo. Atheneu. 10.ed

[7] Oliveira, A. B. A. (2005). Comparação de diferentes protocolos de higienização de alface (Lactuca sativa) utilizados em restaurantes de Porto Alegre - RS. Junho.

[8] Reis, R. R. (2012). Avaliação parasitológica de hortaliças comercializadas em feiras livres da cidade de Anápolis, Goiás. Centro de Pós-Graduação Oswaldo Cruz - IEPG.

[9] Santos, H. S. (2012). Avaliação da eficácia da água sanitária na sanitização de alfaces (Lactuca sativa). Rev Inst Adolfo Lutz. São Paulo; 71(1):56-60.

[10] Tortora, G. J.; Funke, B. R.; Case, C. L. (2016). Microbiologia. $12^{\circ}$ ed. p. 969. 


\section{Capítulo 6}

\section{Avaliação da atividade de antimicrobianos em algodão e poliéster}

\section{Sabrina Cremonini \\ Creciana Maria Endres \\ Crivian Pelisser \\ Andressa Barella de Freitas \\ Josiane Betat da Silva \\ Elisa Sonza}

Resumo: A proliferação de microrganismos em produtos têxteis pode causar problemas tanto para a saúde do consumidor quanto para a estética e qualidade do tecido. Além disso, a indústria têxtil é um dos ramos industriais responsável por uma fatia significativa da economia de países desenvolvidos ou em desenvolvimento. 0 objetivo deste estudo foi avaliar a atividade antimicrobiana em matrizes têxteis de algodão e poliéster. Aplicou-se cinco diferentes aditivos antimicrobianos e utilizou-se como microrganismos contaminantes staphylococcus aureus, Escherichia coli, Klebsiella oxytoca e Cândida albicans. Observou-se que o antimicrobiano 4 (Protec-4) inibiu todos os microrganismos testados, o antimicrobiano 5 (Isso-Act) inibiu o crescimento apenas de staphylococcus aureus e Cândida albicans. Todos os outros antimicrobianos não demonstraram eficácia para os testes realizados. Sugere-se futuros testes, com novos antimicrobianos e outros tipos de microrganismos para que possamos verificar a inibição, bem como estudar as concentrações suficientes para que os microrganismos não se desenvolvam nos tecidos.

Palavras-Chave: Qualidade do tecido; contaminante; aditivos. 


\section{INTRODUÇÃO}

A expansão das atividades da indústria têxtil e o grande volume de produção geram produtos tóxicos e poluidores que podem permanecer no ambiente por longos períodos de tempo. Os produtos têxteis são considerados um bom substrato para o crescimento de microrganismos, particularmente de fungos e bactérias. Esses microrganismos podem encontrar-se isoladamente em diferentes produtos têxteis. Além disso, o desenvolvimento de bactérias e fungos depende de diversos fatores ambientais como umidade, luz, temperatura e poluição.

O crescimento de microrganismos nos têxteis, além de causar alteração no produto, pode acarretar consequências para a saúde do consumidor, causando infecções (Puwar, 2004; Joshi, 2004). Esteves (2009) explica que a aplicação de antimicrobianos naturais ou sintéticos em produtos têxteis é realizada há muito tempo. Esse tipo de aplicação pode ser utilizado para inibir o crescimento de bactérias e fungos, atividade seletiva direcionada a microrganismos indesejáveis, ausência de efeitos tóxicos, tanto para o fabricante como para o consumidor. Devido à importância da aplicação de antimicrobianos naturais, o objetivo deste estudo foi avaliar a atividade de diferentes antimicrobianos em matrizes têxteis de algodão e poliéster.

\section{MATERIAL E MÉTODOS}

Para realização dos testes da avaliação da atividade antimicrobiana em matrizes têxteis, houve a necessidade de preparar os tecidos previamente, com concentração de antimicrobianos fornecidos por uma empresa de aditivos. Foram utilizados cinco antimicrobianos: quatro fornecidos por uma empresa de aditivos, e um de uso interno do Laboratório de microbiologia, a prolimixina B. Os 4 antimicrobianos fornecidos pela empresa, foram utilizados conforme orientação repassada pelo fornecedor conforme pode-se observar na Quadro 1.

Quadro 1: Concentração dos antimicrobianos utilizados na matriz de poliéster e algodão
\begin{tabular}{|cc|c|c|} 
& Antimicrobiano & Concentração & Princípio Ativo \\
\hline 1. & Polimixina B & 1 gota & Polimixina \\
\hline 2. & NpAg_925-ETG & $0,5 \mathrm{~g} / \mathrm{L}$ & Nanoparticulas de Prata \\
\hline 3. & NpAg_925 & $4,0 \mathrm{~g} / \mathrm{L}$ & Nanoparticulas de Prata \\
\hline 4. & Protec-4 & $10,0 \mathrm{~g} / \mathrm{L}$ & Quaternário de amônia \\
\hline 5. & Isso-Act & $10,0 \mathrm{~g} / \mathrm{L}$ & Isotiazolinonas \\
\hline
\end{tabular}

As amostras têxteis foram fornecidas por uma empresa de confecções localizada no Oeste de SC. Uma amostra era de tecido de algodão $96 \%$, e outra de tecido poliéster $100 \%$. 0 teste foi analizado no Laboratório de Análises Microbiológicas do SENAI de Chapecó. Os antimicrobianos testados foram:

- Antimicrobianos 1: Sulfato de polimixina B, marca inlab código 6390 lote 843117.

- Antimicrobiano 2: NpAg_925-ETG. Consiste em uma mistura inorgânica de Etilenoglicol (C2H6O2), PVP, água e Prata $(\mathrm{Ag})$ e seu nome comum é emulsão de nanopartículas de prata estabilizado com surfactante.

- Antimicrobiano 3: NpAg_925. A composição e informação do ingrediente consiste em uma mistura inorgânica de água, surfactante (segredo comercial), e prata (Ag) e o nome comum desta composição é emulsão de nanopartículas de prata estabilizada com surfactante.

- Antimicrobiano 4: Protec-4 Consiste em um aditivo antimicrobiano a base em uma composição de quaternário de amônia, sua caracterização química consiste em uma solução hidro alcoólica de Cloreto de Alquil Dimetil Benzil Amônio 80\%.

- Antimicrobiano 5: Iso-Act - Sua caracterização química se dá a uma solução aquosa de Isotiazolinona, em uma combinação de 2-Metil-4-isotiazolona e 5-Cloro-2-Metil-4-isotiazolona-3, e água. 


\subsection{APLICAÇÃO DOS ANTIMICROBIANOS}

Para o antimicrobiano 1 (polimixina B), foi utilizado uma concentração de uma gota da solução na amostra do têxtil de poliéster. A impregnação dos tecidos com os antimicrobianos 2,3,4 e 5 foi realizada através de imersão em solução de água destilada. Esses aditivos foram disponibilizados pela empresa prontos para uso, porém foram apenas pesados conforme concentração repassada pelo fornecedor. Após a pesagem, foram dissolvidos em 1L de água destilada. As amostras de tecido foram cortadas com as dimensões de \pm $2,5 \mathrm{~cm} \times 1,5 \mathrm{~cm}$ conforme recomenda a norma AATCC 147. Mergulhou-se as amostras têxteis para a impregnação do aditivo antimicrobiano, deixou-se agir por 20 minutos em seguida retirou-se os têxteis e colocou-se em estufa para secar por um período de 5 minutos a uma temperatura de $150{ }^{\circ} \mathrm{C}$.

Após a etapa de impregnação (pad-dry) todas as amostras e também a amostra controle (sem antimicrobiano) foram sujeitas a um processo de esterilização através de calor seco em estufa específica e validada para esterilização de materiais, a uma temperatura de $180^{\circ} \mathrm{C}$ durante 90 minutos. Foram utilizadas três culturas de bactérias e uma cultura de fungos selecionados de acordo com a finalidade das amostras. As bactérias utilizadas ao longo do trabalho foram as seguintes: Escherichia coli ATCC $®$ 25922TM, Staphylococcus aureus AATCC® 25923, Klebsiella oxytoca. O fungo utilizado no estudo foi a levedura Cândida albicans AATCC® 10231 TM. A bactéria Klebsiella oxytoca, foi isolada no LANAL microbiologia e identificada utilizando o sistema Vitek®2.

Após realizado o processo de estrias nas placas contendo os meios de culturas, as mesmas foram incubadas a uma temperatura $37^{\circ} \mathrm{C}$ por $24 \mathrm{~h}$ para bactérias Echerichia coli, Sthaphylococcus aures $e$ Klebsiela oxytona, e para fungos Cândida albicans, a uma temperatura de $25^{\circ} \mathrm{C} \pm 1$ por 5 dias. Passando este período de incubação as placas foram observadas macroscopicamente e avaliado a ação do antimicrobiano quanto a presença ou ausência de estrias de crescimento.

\section{RESULTADOS E DISCUSSÃO}

Para avaliar a eficácia dos antimicrobianos aplicados nos têxteis, foi utilizado a norma AATCC 147 (Atividade antimicrobiana em têxteis: AATCC 147 -Avaliação da atividade antibacteriana em têxteis: método de estrias paralelas). Nessa norma são referenciados apenas os microrganismos Staphylococcus aureus e Klebsiella pneumoniae como microrganismo teste. Durante o desenvolvimento deste estudo foram utilizados outros microrganismos além do $S$. aureus que está descrito na norma, utilizou-se as bactérias Escherichia coli e Klebsiella oxytoca e para fungos Cândida albicans, como representantes de grupo diferentes e pelas causas das infecções superficiais.

A matriz de poliéster, não mostrou qualquer atividade contra os microrganismos testados, sendo observado o crescimento do meio Triptona de Soja Agar TSA conforme (Tabela 2). Para além do têxtil foi testado uma amostra sem tratamento que correspondia a uma amostra de poliéster $100 \%$, onde foi estreado todos os microrganismos utilizados neste trabalho e observou-se o crescimento de todos eles.

0 têxtil de algodão 96\%, mostrou-se eficiente (Tabela 2), na utilização do antimicrobiano aditivo base de quaternário de amônia (Protc-4) para a bactéria de Staphylococcus aureus e para o fungo Cândida albicans já para os outros dois microrganismos Escherichia coli e Klebsiella oxytoca o mesmo não foi eficaz. 0 antimicrobiano aditivo a base de isotiazolinonas (Iso-Act), inibiu o crescimento dos microrganismos testados, já os antimicrobianos de prata metálica em meio alcoólico, estabilizada com moléculas orgânicas (NpAg-EGE) e (NpAg-925) não mostrou eficiência sendo assim o desenvolvimento dos microrganismos no têxtil. Além das amostras com tratamento foi testado uma amostra sem tratamento que correspondia a uma amostra de algodão $96 \%$ observando o crescimento de todos os microrganismos testados neste trabalho. 
Com base nos testes avaliados observou-se macroscopicamente o crescimento e a ausência de microrganismos e os resultados obtidos da atividade antimicrobiana em matrizes têxteis apresentam-se na Quadro 2:

Quadro 2: Resultados de atividade antimicrobiana para o têxtil de Algodão 96\% e poliéster 100\%

\begin{tabular}{|c|c|c|c|c|c|c|c|}
\hline \multirow[b]{2}{*}{$\mathrm{N}^{0}$} & \multirow[b]{2}{*}{ Têxteis } & \multirow[b]{2}{*}{ Antimicrobiano } & \multirow[b]{2}{*}{ Concentração } & \multicolumn{4}{|c|}{ Microrganismos } \\
\hline & & & & $\begin{array}{c}\text { Staphylococcus } \\
\text { aureus }\end{array}$ & $\begin{array}{c}\text { Escherichia } \\
\text { coli }\end{array}$ & $\begin{array}{c}\text { Klebsiella } \\
\text { oxytoca }\end{array}$ & $\begin{array}{l}\text { Cândida } \\
\text { albicans }\end{array}$ \\
\hline 1 & $\begin{array}{c}\text { Poliéster } \\
100 \% /\end{array}$ & Polimixina B & 1 gota & $(+)$ & $(+)$ & $(+)$ & $(+)$ \\
\hline 2 & $\begin{array}{c}\text { Algodão } \\
96 \%\end{array}$ & NpAg_925-ETG & $0,5 \mathrm{~g} / \mathrm{L}$ & $(+)$ & $(+)$ & $(+)$ & $(+)$ \\
\hline 3 & $\begin{array}{l}\text { Algodão } \\
96 \%\end{array}$ & NpAg_925 & $4,0 \mathrm{~g} / \mathrm{L}$ & $(+)$ & $(+)$ & $(+)$ & $(+)$ \\
\hline 4 & $\begin{array}{c}\text { Algodão } \\
96 \%\end{array}$ & Iso-Act & $10,0 \mathrm{~g} / \mathrm{L}$ & $(-)$ & $(-)$ & $(-)$ & $(-)$ \\
\hline 5 & $\begin{array}{c}\text { Algodão } \\
96 \%\end{array}$ & Protec- 4 & $10,0 \mathrm{~g} / \mathrm{L}$ & $(-)$ & $(+)$ & $(+)$ & $(-)$ \\
\hline 6 & $\begin{array}{c}\text { Poliéster } \\
100 \%\end{array}$ & Sem tratamento & - & $(+)$ & $(+)$ & $(+)$ & $(+)$ \\
\hline 7 & $\begin{array}{l}\text { Algodão } \\
96 \%\end{array}$ & Sem tratamento & - & $(+)$ & $(+)$ & $(+)$ & $(+)$ \\
\hline
\end{tabular}

Legenda: (+) Crescimento de microrganismos no têxtil, (-). Ausência de crescimento do microrganismo no têxtil. Fonte: autor, 2019

Para amostra têxtil de poliéster $100 \%$, foi adicionado o antimicrobiano polimixina B, o teste não foi eficaz pois os microrganismos mostraram-se resistentes à concentração do aditivo tanto para as bactérias quanto para fungo. Moura (2014), afirma que a polimixina B tem uma bactericida bastante efetiva e rápida para uma variedade de bactérias Gran - negativas, e é bastante eficaz no tratamento de meningite, infecção no trato urinário infecção cutânea e ocular, atuando como um antibiótico ela se insere na membrana celular bacteriana fixando-se ao lipídio, tornando-se sua barreira osmótica ineficaz, levando a morte celular bactéria. Porém sua aplicação é bastante eficaz para tratamento de infecção como antibiótico e para este teste se mostrou-se não resistente.

A amostra de algodão $96 \%$ que foi adicionado o antimicrobiano emulsão de nanopartículas de prata estabilizado com surfactante (NpAg_925-ETG) com uma concentração de 0,5g, para os microrganismos testados também não foram eficaz, pois os mesmos mostraram-se resistência a concentração do aditivo, e obtivemos o crescimentos dos mesmos microganismos no têxtil. Observa-se que a nanoparticulas de prata tem um papel muito eficaz em processos antimicrobianos, porém para este teste tanto para a concentração de $0,5 \mathrm{~g}$ quanto para a concentração de 4,0g utilizada não foi eficaz.

Para a amostra de algodão 95\% onde o antimicrobiano utilizado foi o aditivo antimicrobiano a base de isotiazolinonas (Iso-Act) com uma concentração de $10 \mathrm{~g}$, a inibição foi totalmente eficaz, pois o mesmo inibiu o crescimento microrganismos no têxtil.

A utilização de conservantes a base de formaldeído das formulações de produtos em 2008 foi banida, devido a sua reconhecida classificação de toxicologia, pela IARC - International Agency for Research on Cance. Em seguida então foi divulgado uma lista de conservantes permitidos a resolução vigente é a RDC 30 de 04 de Julho 2011, onde que a utilização de isotiazolinonas além de ser seguro, possui efeitos com baixas concentrações (Araújo, 2015). Para amostra de algodão 96\% onde o antimicrobiano utilizado foi o aditivo antimicrobiano a base de quaternário de amônia (Protec-4), com concentração de 10g, somente para o microrganismo Staphylococcus aures amostra a direita inferior foi eficaz, os demais microrganismos mostraram-se resistência a essa concentração, onde observou-se crescimento no têxtil. (Gutarowska, 2012)

Para Nascimento (2010), os compostos a base de quaternário de amônio quando em contato com a membrana celular do microrganismo alteram sua permeabilidade estimulando assim o esgotamento celular. Possui vantagem a ser fácil o preparo e aplicação, neutralizam odores e tem um amplo aspecto de ação com as bactérias Gram - positivas. 
Durante o estudo foram utilizados para controle juntamente com as amostras que havia tratamento uma amostra de algodão 96\% sem tratamento aplicado para a bacterias Staphylococcus auereus, e uma amostra de poliester 100\% aplicada para o fungo Cândida Albicans. Essa amostra serviu essencialmente para ser observada a presença ou ausência do crescimento microbiano, e uma comparação eficaz da importância dos aditivos antimicrobiano em têxteis.

\section{CONCLUSÕES}

Magalhães (2015), afirma que a avaliação antimicrobiana de produtos têxteis é necessária. Durante o estudo ficou evidenciado que a atividade de um antimicrobiano é dependente do método de aplicação (impregnação) ou qualquer outro método, do processamento que sofre durante a fabricação e das concentrações.

Apesar de existirem diversos estudos que mostram a atividade antibacteriana/ antifúngica de antimicrobianos naturais e sintéticos e de têxteis funcionalizados com esses compostos, é ainda necessário desenvolver outros estudos mais conclusivos.

Sugere-se para futuros estudos avaliar as concentrações e métodos de impregnação de antimicrobianos para ser aplicado nos têxteis, pois alguns microrganismos se tornam resistententes a poucas concentrações ou não, e dependendo da concentração não conseguem eliminar a célula existente dos microrganismos. Torna-se necessário futuros testes, com novos antimicrobianos e outros tipos de microrganismos para que possamos verificar o quanto é inibidor do crescimento e que concentrações são o suficientes para que os microrganismos não se desenvolvam no têxteis.

\section{REFERÊNCIAS}

[1] Araújo, A.E., Passos, F. F. Lorena, R. Pereira, A. A., Junior, F.Q.F.J., Nanopartículas de prata: método alternativo de sanitização para couve minimamente processada. Goiânia, 2015.

[2] Gutarowska, B., Michalski A.: Microbial degradation of woven fabrics and protection against biodegradation. woven fabrics. Intech open access publisher. 2012.

[3] Moura, B. L., Fonseca, D. C., Watanabe, M., Vattimo, F.F.M. Polimixina B: Efeito dose e tempo dependente na nefrotoxicidade in vitro polymyxin b: dose and time dependent nephrotoxicity effect in vitro, 2013

[4] Magalhães, A, S, P., A.; Atividade antimicrobiana em têxteis. Faculdade de Farmácia Universidade do Porto, 2015.

[5] Nascimento H.M, Delgado, Barbaric if. avaliação da aplicação de agentes sanitizantes como controladores do crescimento microbiano na indústria alimentícia. Revista Ceciliana, 2010. 


\section{Capítulo 7}

Avaliação da atividade antibacteriana de óleo essencial de pimenta rosa e sua aplicação biofilme de colágeno

\section{Felipe Ozorio Giacomelli}

Suslin Raatz, Thiel

Andrine Menna da Fontoura

Mari Silvia Rodrigues de Oliveira

Rosa Cristina Prestes Dornelles

Resumo: 0 aumento na busca de conservantes de alimentos de origem natural foi uma das principais motivações para este estudo que teve por objetivo avaliar a atividade antimicrobiana do óleo essencial de pimenta rosa (OEPR) puro e quando aplicado a um biofilme elaborado a partir de fibra de colágeno. A metodologia utilizada foi o teste de disco difusão, realizado em bactérias relacionadas com o controle de qualidade de alimentos. O OEPR apresentou melhor inibição no crescimento nas bactérias Gram positivas, quando comparado as Gram negativas. No estudo de aplicação só houve diferença estatística quando comparada a adição ou não de OEPR na elaboração de filmes. A diferença de concentração de óleo não apresentou diferenças significativas

Palavras-Chave: microbiologia; biofilme; qualidade; segurança alimentar; aditivo natural.

Artigo publicado como resumo expandido em Anais do $7^{\circ}$ Simpósio de Segurança Alimentar. ISBN online 978-65-992839-0-1, de 27 a 29 de outubro de 2020, Porto Alegre, RS: Sociedade Brasileira de Ciência e Tecnologia de Alimentos. 


\section{INTRODUÇÃO}

Os alimentos são vetores importantes de muitos microrganismos que fazem mal a saúde. Staphylococcus sp. e Escherichia coli representam $7 \%$ e $5 \%$ das infecções bacterianas de origem alimentar, respectivamente (Dussault et al., 2014). A deterioração dos alimentos e a formação de biofilmes causados por bactérias patógenas são problemas sérios na indústria de alimentos, sendo necessário o uso de substâncias antibacterianas que possam inibir e eliminar efetivamente estes microrganismos (Cui et al., 2020) para melhorar a vida de prateleira dos produtos. Os consumidores têm rejeitados produtos com uso excessivo de conservantes sintéticos ou que fujam muito do estado natural (Calo et al., 2015). Nesse contexto, a busca de novas substâncias com atividade antimicrobiana, principalmente naturais, aparece como uma alternativa potencial (Dussault et al., 2014).

Os óleos essenciais (OEs) são líquidos aromáticos e voláteis, que contêm uma mistura de compostos orgânicos, que são extraídos de matéria vegetal. Geralmente os OEs possuem um sabor e aroma forte, dependente da fonte e extração, por este fato são compostos amplamente utilizados na indústria de alimentos. Os OEs são compostos com atividades antimicrobianas (Cui et al., 2019; Cui et al., 2020; Dannenberg et al., 2017) e antioxidantes (Kacaniova et al. 2017; Tohidi et al., 2017) comprovadas por vários estudos, e devido este fato seu estudo para utilização como aditivo alimentar tem aumentado muitos nos últimos anos (Kacaniova et al., 2017).

A pimenta rosa é muito usada, por certos grupos folclóricos, para combater infecções e apenas recentemente surgiram pesquisas científicas para provar a atividade biológica do seu OE (Dannenberg et al., 2019). Devido estes poucos estudos, o objetivo deste trabalho foi avaliar a ação antibacteriana do óleo essencial de pimenta rosa (OEPR) puro e aplicado em um biofilme de fibra de colágeno em testes microbiológicos de disco difusão.

\section{MATERIAL E MÉTODOS}

\subsection{AMOSTRAS}

A amostra de fibra de colágeno bovino foi fornecida pela NovaProm Food Ingredients Ltda. (Lins, SP, Brasil). A pimenta rosa foi adquirida de um o produtor na região de Turuçu - RS.

\subsection{EXTRAÇÃO DO ÓLEO ESSENCIAL}

0 óleo essencial de pimenta rosa foi extraído através do método de arraste a vapor, utilizando o equipamento Clevenger. Para a extração foram utilizados $65 \mathrm{~g}$ de pimenta rosa moída previamente em liquidificador (Walita Liqfaz®) e $600 \mathrm{~mL}$ de água destilada.

\subsection{PRODUÇÃO DOS FILMES}

A solução dos filmes foi preparada com $5 \%(\mathrm{p} / \mathrm{v})$ de fibra de colágeno em água destilada e glicerol a $25 \%$ $(\mathrm{p} / \mathrm{p})\left(\mathrm{em}\right.$ relação à massa de colágeno). As soluç̧ões filmogênicas foram aquecidas em banho maria à $70^{\circ} \mathrm{C}$ por 20 min. Os filmes foram adicionados de 1\% (v/v) de óleo essencial e Tween 80 ( $1 \mathrm{~g} / 100 \mathrm{~mL})$ de solução. As soluções foram dispostas em placas de vidro $(30 \times 21 \mathrm{~cm})$ e secas em estufa com circulação de ar a $25-30^{\circ} \mathrm{C}$ por $24 \mathrm{~h}$. Após a secagem, os filmes foram acondicionados em dessecadores a temperatura de $16^{\circ} \mathrm{C}$. Foram preparados três tratamentos com diferentes formulações, sendo: T1 $(0 \%$ de OE), T2(1\% OE) е T3(2\% OE).

\subsection{CEPAS DE MICRORGANISMOS}

Foram utilizadas amostras de bactérias da American Type Culture Collection (ATCC) recomendadas como controle de qualidade dos testes de susceptibilidade: Staphylococcus aureus (ATCC 6538, CCT 4295, Lote 61.16), Escherichia coli (ATCC 8739, CCT 1371, Lote 44.16B). 


\subsection{PREPARO DOS INÓCULOS}

As cepas das bactérias estavam armazenadas, sob refrigeração, em solução de glicerol. Para a ativação as bactérias foram dispostas, através de alçadas, em ágar BHI (Brain Heart Infusion, Kasviß) e incubadas em estufa microbiológica a $37^{\circ} \mathrm{C}$ por aproximadamente 24 horas.

\subsection{TESTE DE DISCO DIFUSÃO}

Inicialmente determinou-se a atividade antimicrobiana do óleo essencial de pimenta rosa pela técnica de disco-difusão (CLSI, 2015a). As culturas bacterianas foram suspensas em solução salina $(0,85 \%)$ para ajustar a concentração de $108 \mathrm{UFC} / \mathrm{mL}$ (0,5 McFarland), verificada com o auxílio do espectrofotômetro. Foi adicionado 0,1 mL de cultura em placas com ágar BHI (Kasvi®) e espalhadas com auxílio de uma alça de Drigalski. Para o teste do óleo puro cada placa recebeu um disco estéril com adição posterior de $10 \mu \mathrm{L}$ do óleo essencial. Para o segundo teste cada placa recebeu um disco de biofilme de fibra de colágeno com diferentes concentrações de óleo essencial $(0,1$ e 2\%) dispostos nas placas de ágar BHI com a cultura bacteriana. Ambos tratamentos foram incubados a $37^{\circ} \mathrm{C}$ durante 24 horas. Após o período de incubação analisou-se a existência de halos de inibição que foram medidos com paquímetro.

\subsection{ANÁLISE ESTATÍ́STICA}

Os resultados obtidos foram submetidos à análise de variância significativo ao nível de $5 \%$ de probabilidade $(\mathrm{p}<0,05)$, foi realizada a comparação de médias pelo Teste de Tukey $(\mathrm{p}<0,05)$, utilizandose o programa Statistic 7.0.

\section{RESULTADOS E DISCUSSÃO}

Os valores dos tamanhos das zonas de inibição, medidas em milímetros, referentes aos testes de disco difusão são apresentados nas Tabelas 1 e 2 . A Tabela 1 apresenta a inibição do óleo puro e a Tabela 2 os resultados da inibição do óleo aplicado no biofilme de fibra de colágeno.

Tabela 1: Resultados do teste de disco difusão de óleo essencial de pimenta

\begin{tabular}{|c|c|}
\hline Bactéria & Zona de inibição(mm) \\
\hline Staphylococcus aureus & $5,14 \pm 1,44 \stackrel{a}{a}$ \\
\hline Escherichia coli & $1,75 \pm 0,76^{b}$ \\
\hline
\end{tabular}

Pode observar-se uma maior zona de inibição do óleo essencial de pimenta rosa nas culturas de $S$. aureus, comprovado pela diferença estatística significativa entre as duas bactérias. Isto está de acordo com os resultados apresentados por Dannenberg et al. (2019) que encontraram em seus estudos maiores zonas de inibição para bactérias Gram positivas quando comparadas a Gram negativas. Este fato é evidenciado em grande parte dos estudos com OE e pode ser justificado devido a diferença das estruturas das bactérias. As Gram positivas apresentam camada simples, enquanto as negativas possuem uma membrana extra com camada de lipopolissacarídeos (Nazzaro et al., 2013). Esta camada extra das Gram negativas dificulta a ação dos OE (Silva et al., 2009; Rai et al., 2017).

Tabela 2: Resultados do teste de disco difusão do OE aplicado em biofilme

\begin{tabular}{|c|c|c|}
\hline & Tratamento & bição (mm) \\
\hline \multirow{3}{*}{$\begin{array}{c}\text { Staphylococcus } \\
\text { Aureus }\end{array}$} & T1 & ND b \\
\hline & $\mathrm{T} 2$ & $1,05 \pm 0,07 \stackrel{a}{a}$ \\
\hline & T3 & $0,90 \pm 0,14$ a \\
\hline
\end{tabular}

Letras minúsculas diferentes nas colunas diferem significativamente $(\mathrm{p}<0,05)$. T1: filme controle.

T2: filme com $1 \%$ de $\mathrm{OE}$. T3: filme com $2 \%$ de OE. ND: não detectado 
Como é visualizado na Tabela 2, a adição de OE foi benéfica para a inibição de crescimento bacteriano. 0 filme controle (T1) não apresentou halo de inibição de crescimento de Staphylococcus aureus. A incorporação de 1\% (T2) e 2\% (T3) de OE nos filmes demonstrou atividade antibacteriana, mas a variação da concentração não apresentou diferença estatisticamente significativa. Este fato está em desacordo com estudos de Dannenberg et al, 2017, Cui et al., 2020, e Devi et al., 2017, onde é apresentado que a maior concentração de óleo essencial apresenta maior nível de inibição de crescimento.

\section{CONCLUSÕES}

Os óleos essenciais possuem propriedades biológicas de grande valor para as indústrias, principalmente em relação a atividade antimicrobiana. Os resultados do presente estudo sugerem que o OE de pimenta rosa é uma fonte potencial de conservação alimentar natural para ser usado pela indústria de alimentos, buscando assim atender as demandas dos consumidores por produtos mais "verdes". Necessita-se mais estudos, com diferentes concentrações de OE para definir o melhor nível de adição nos produtos.

\section{REFERÊNCIAS}

[1] CALO, J. R.; CRANDALL, P. G.; O'BRYAN, C.A.; RICKE, S.C. Essential oils as antimicrobials in food systems - a review. Food Control, v. 54, p.111-119, 2015.

[2] CLSI a. M02-A12: Performance standards for antimicrobial disk susceptibility tests; approved standardTwelfth Edition. CLSI (Clinical and Laboratory Standards Institute), 35(1), 2015.

[3] CUI, H.; ZHANG, C.; LI, C.; LIN, L. Inhibition mechanism of cardamom essential oil on methicillin-resistant Staphylococcus aureus biofilm. LWT, v. 122, p. 109057, 2020.

[4] CUI, H.; ZHANG, C.; LI, C.; LIN, L. Antibacterial mechanism of oregano essential oil. Industrial Crops and Products, v. 139, p. 111498, 2019.

[5] DANNENBERG, G.S.; FUNCK, G.D.; CRUXEN, C.E.S.; MARQUE, J.L.; SILVA, W.P.; FIORENTINI, A.M. Essential oil from pink pepper as an antimicrobial component in cellulose acetate film: Potential for application as active packaging for sliced cheese. LWT-Food Science and Technology, v. 81, p. 314-318, 2017.

[6] DANNENBERG, G. S.; FUNK, G. D.; DA SILVA, W. P.; FIORENTINI, A. M. Essential oil from pink pepper (Schinus terebinthifolius Raddi): Chemical composition, antibacterial activity and mechanism of action. Food Control, v. 95, p. 115-120, 2019.

[7] DEVI, V. D.; KALPANA, G.; SARANRAJ, P. Antibacterial activity of Essential oils against human pathogenic bacteria. Advances in Biological Research, v. 11, n. 6, p. 357-364, 2017.

[8] DUSSAULT, D.; VU, K.D.; LACROIX, M. In vitro evaluation of antimicrobial activities of various commercial essential oils, oleoresin and pure compounds against food pathogens and application in ham. Meat Science, v. 96, n. 1, p. 514-520, 2014.

[9] KACANIOVA, M.; TERENTJEVA, M.; VUKOVIC, N.; PUCHALSKI, C.; ROYCHOUDHURY, S.; KUNOVA, S.; KLUGA, A.; TOKAR, M.; KLUZ, M.; IVANISOVA, E. The antioxidant and antimicrobial activity of essential oils against Pseudomonas spp. isolated from fish. Saudi Pharmaceutical Journal, v. 25, n. 8, p. 1108-1116, 2017.

[10] NAZZARO, F.; FRATIANNI, F.; MARTINO, L. Effect of essential oils on pathogenic bacteria Pharmaceuticals, v. 6, n. 12, p. 1451-1474, 2013.

[11] RAI, M.; PARALIKAR, P.; JOGEE, P.; AGARKAR, G.; INGLE, A.P.; DERITA, M. Synergistic antimicrobial potential of essential oils in combination with nanoparticles: emerging trends and future perspectives. International Journal of Pharmaceutics, v. 519, n. 1-2, p. 67-78, 2017.

[12] SILVA, M.T.N.; USHIMARU, P.I.; BARBOSA, L.N.; CUNHA, M.L.R.S.; JUNIOR, A.F. Antibacterial activity of plant essential oils against Staphylococcus aureus and Escherichia coli strains isolated from human specimens. Revista Brasileira de Plantas Medicinais, v. 11, n. 3, p. 257-262, 2009.

[13] TOHIDI, B.; RAHIMMALEK, M.; ARZANI, A. Essential oil composition, total phenolic, flavonoid contents, and antioxidant activity of Thymus species collected from different regions of Iran. Food Chemistry, v. 220, p. 153-161, 2017. 


\section{Capítulo 8}

Aplicação de aditivo antimicrobiano para embalagens de queijo parmesão ralado

\section{Letícia Santa Catarina}

Rita de Cassia Soares

Creciana Maria Endres

Elisa Sonza

Crivian Pelisser

Jaqueline Lidorio de Mattia

Andréia Maria Faion

Resumo: As embalagens de queijo ralado têm como principais funções evitar grandes perdas de umidade e contaminações microbianas. Para verificar a influência de uma embalagem diferenciada, utilizou-se uma embalagem A (amostra controle) e embalagem $\mathrm{B}$ (com aditivo antimicrobiano), nas quais foram adicionados $40 \mathrm{~g}$ de queijo parmesão ralado e após 25 dias de armazenagem a temperatura ambiente, avaliou-se os microrganismos: coliformes termotolerantes, Estafilococos coagulase positivo, Salmonella spp., bolores e leveduras, Listeria monocytogenes, contagem de Escherichia coli. Os resultados demonstraram que possivelmente o aditivo antimicrobiano reduziu o crescimento de bolores e leveduras, aumentando assim a qualidade e o shelf- life do produto.

Palavras-Chave: queijo parmesão ralado, aditivo antimicrobiano, tendências em embalagens. 


\section{INTRODUÇÃO}

Aliado ao processo de conservação de alimentos utiliza-se as embalagens. A combinação de embalagens, temperatura de armazenamento e processamento possibilita estender a vida útil dos alimentos e até mesmo inibir o desenvolvimento microbiano. Porém além de inibir o crescimento microbiano existe a necessidade de reduzir as contagens de alguns microrganismos deteriorantes e patogênicos. Para isso tem sido estudado a aplicação de antimicrobianos nas embalagens usadas para acondicionamento de produtos alimentícios (CAPELEZZO et al., 2018).

Um produto interessante para a utilização de embalagens adicionadas de antimicrobianos é o queijo, pois apresenta características que favorecem o crescimento microbiano, principalmente microrganismos deteriorantes como é o caso dos bolores e leveduras. 0 queijo parmesão é maturado por longos períodos, para após ser ralado, facilitando dessa forma a proliferação de alguns microrganismos. A necessidade de o alimento possuir uma embalagem segura faz com que a indústria alimentícia invista cada vez mais em tecnologia e o tipo de embalagem que o alimento será acondicionado. Segundo Sarantópoulos, et al. (2001), após o período de cura, a vida de prateleira dos queijos é limitada por reações químicas, bioquímicas e microbiológicas, que podem ser retardadas pela armazenagem adequado. Uma grande variedade de microrganismos está envolvida na maturação de queijos; a população total geralmente excede a $10^{9}$ microrganismos/grama. Os contaminantes mais comuns e que podem representar riscos à saúde do consumir e diminuir a vida de prateleira dos derivados lácteos são os coliformes termotolerantes, Estafilococos coagulase positivos, Salmonella spp., bolores e leveduras, Listeria monocytogenes, dentre outros.

Borges, (1999) afirma que as leveduras, como os bolores, são fungos, mas deles se diferenciam por se apresentarem, usual e predominantemente, sob forma unicelular. Como os bolores, as leveduras são tanto benéficas quanto prejudiciais. Bactérias e fungos se desenvolvem em ambientes que oferecem alimento, umidade e temperatura adequados para seu crescimento. Nossas mãos constituem a principal via de transporte de microrganismos que pode ocorrer por contato direto (pele com pele), ou indireto, através do contato da mão com objetos e superfícies contaminados. De tal modo, as pessoas estão frequentemente expostas aos riscos da contaminação microbiana. Neste sentido, a utilização de embalagens seguras e que inibem a proliferação e reduzem as contagens de microrganismos é de grande importância quando se fala de segurança alimentar.

Para a produção de embalagens com características de inibição e redução microbiana são utilizados diversos agentes microbianos, como é o caso do 19244-AN - MB, esse é à base de zinco, atóxico, atua eliminando os microrganismos quando em contato com a superfície da embalagem, pode ser incorporado a vários tipos de matrizes poliméricas e atua diretamente na eliminação de bactérias e fungos com altos níveis de eficiência e durabilidade para o produto. Diante disso, o objetivo do trabalho foi verificar a influência do aditivo antimicrobiano 19244-AN - MB em embalagens para queijo tipo parmesão ralado, afim de verificar sua eficácia na redução da contagem de coliformes termotolerantes, Escherichia coli, Estafilococos coagulase positiva, bolores e leveduras, detecção de Listeria monocytogenes e Salmonella ssp.

\section{MATERIAL E MÉTODOS}

\subsection{EMBALAGENS ANTIMICROBIANAS}

Para a elaboração das embalagens, utilizou-se o polietileno (Brasken S/A) e o filme de PET. O agente MB antimicrobiano 19244 AN atóxico e isento de materiais a base de metais pesados. As embalagens foram elaboradas em uma empresa de embalagens parceira localizada na região Oeste de Santa Catarina, conforme a Quadro 1. 
Quadro 1 - Composição das embalagens confeccionadas sem aditivo antimicrobiano e com aditivo antimicrobiano.

\begin{tabular}{|c|l|c|}
\multirow{2}{*}{ Tipo de embalagem } & \multicolumn{2}{|c}{$\begin{array}{c}\text { Aditivo } \\
\text { antimicrobiano }\end{array}$} \\
\hline \multirow{4}{*}{ Embalagem A } & PEBDL (Polietileno de Baixa Densidade Linear) & \multirow{2}{*}{ Não contém } \\
\cline { 2 - 2 } & PEBD (Polietileno de Baixa Densidade & \\
\cline { 2 - 2 } & PEBDL (Polietileno de Baixa Densidade Linear Metaloceno) & \\
\cline { 2 - 2 } & Laminação com filme PET transparente. & \multirow{2}{*}{ MB 19244 - Aditivo } \\
\hline \multirow{4}{*}{ Embalagem B } & PEBDL (Polietileno de Baixa Densidade Linear) & \\
\cline { 2 - 2 } & PEBD (Polietileno de Baixa Densidade) & \\
\cline { 2 - 2 } & PEBDL (Polietileno de Baixa Densidade Linear Metaloceno) \\
\cline { 2 - 2 } & Laminado com filme PET transparente. & \\
\hline
\end{tabular}

Fonte: Do autor, 2020.

Os polímeros foram extrusados através de extrusora monocamadas (Marca: Carnevali), com temperaturas que chegam até $220^{\circ} \mathrm{C}$.

\subsection{PREPARO DAS AMOSTRAS DE QUEIJO RALADO}

As amostras de queijo tipo parmesão ralado, foram gentilmente cedidas por uma empresa localizada na região Oeste de Santa Catarina. 0 acondicionamento das amostras nas embalagens A (amostra controle) e B (com aditivo antimicrobiano), foram realizadas na planta piloto da Faculdade Senai de Chapecó, ambas com 40 g e posteriormente foram armazenadas durante 25 dias em temperatura ambiente. Os ensaios foram realizados em duplicata. As amostras foram submetidas a testes de umidade, teor de cinzas e cloretos.

\subsection{ANÁLISES MICROBIOLÓGICAS}

Os ensaios microbiológicos avaliaram os principais microrganismos presentes no queijo tipo parmesão ralado, seguindo a metodologia descrita na Quadro 2.

Quadro 2 - Ensaios microbiológicos realizados para as amostras de queijo tipo parmesão ralado acondicionados nas embalagens A e B.

\begin{tabular}{|l|l|}
\multicolumn{1}{c|}{ Ensaio } & \multicolumn{1}{c|}{ Metodologia } \\
\hline Contagem de Bolores e Leveduras (PETRIFILM) & AOAC OMA 997.02. 20th ed., 2016 \\
\hline Contagem de Coliformes Termotolerantes (PETRIFILM) & AFNOR 3M 01/2 - 09/89C \\
\hline Contagem de Estafilococos coagulase positiva & ISO 6888 - 1: 1999; ISO 6888 - 1:/Amd 1:2003 \\
\hline Detecção de Listeria monocytogenes & ISO 11290-1:2017 \\
\hline Detecção de Salmonella spp (VIDAS) & $\begin{array}{l}\text { AOAC OMA 2011.03. 20th ed., 2016 AFNOR } \\
\text { BIO 12/16-09/05 }\end{array}$ \\
\hline Contagem de Escherichia coli (PETRIFILM) & $\begin{array}{l}\text { AOAC OMA 998.08. 20th ed., 2016 AOAC OMA } \\
\text { 991.14. 20th ed., 2016 }\end{array}$ \\
\hline
\end{tabular}

Fonte: Do autor, 2020.

\section{RESULTADOS E DISCUSSÕES}

0 teor de umidade das amostras de queijo tipo parmesão ralado foi de 15,45 $\pm 1,24 \%$ o que está de acordo com a Portaria 357 - Regulamento técnico para fixação de identidade e qualidade de queijo ralado que estabelece um teor máximo de umidade de $20 \%$ (m/m) (BRASIL, 1997). 0 teor de cinzas determinado foi de 7,85\% e o teor de cloretos foi de 5,95 $\pm 0,56 \%(\mathrm{~m} / \mathrm{m})$. Resultados semelhantes também foram encontrados por Pereira et al. (2016) em seu estudo sobre queijos parmesão ralado sendo que quantidade de cloreto de sódio incorporada aos queijos influi diretamente no teor de cloretos, bem como representa uma proporção considerável das cinzas encontradas no produto.

As amostras de queijo tipo parmesão ralado acondicionadas nas embalagens A (sem uso de aditivo antimicrobiano) e B (com uso de aditivo antimicrobiano) submetidas a análises de contagem de coliformes termotolerantes, E. coli, Estafilococos coagulase positiva, detecção de Listeria monocytogenes e Salmonella ssp, não apresentaram diferenças na contagem. Porém, as duas amostras atenderam a legislação que 
estabelece os critérios de aceitação para queijo ralado, conforme a RDC 12 - Regulamento Técnico sobre os Padrões Microbiológicos para Alimentos (Brasil, 2001). Evidencia-se os resultados na Tabela 1.

Tabela 1 - Análises microbiológicas nas amostras de queijo tipo parmesão ralado acondicionadas nas embalagens A (Amostra controle) e B (Amostra com adição do antimicrobiano).

\begin{tabular}{|l|c|c|c|}
\multicolumn{1}{c}{$\begin{array}{c}\text { Ensaio } \\
\text { Contagem de Coliformes Termotolerantes }\end{array}$} & $\begin{array}{c}\text { Restado Amostra A } \\
\text { (UFC/g) }\end{array}$ & $\begin{array}{c}\text { Resultado Amostra B } \\
\text { (UFC/g) }\end{array}$ & $\begin{array}{c}\text { RDC } n^{\circ} 12 \\
\text { (ANVISA, 2001) }\end{array}$ \\
\hline Contagem de Estafilococos coagulase positiva & $<1,0 \mathrm{E}+02$ & $<1,0 \mathrm{E}+01$ & $1,00 \mathrm{E}+03$ \\
\hline Detecção de Listeria monocytogenes & Ausência & Ausência & Ausência \\
\hline Detecção de Salmonella ssp & Ausência & Ausência & Ausência \\
\hline Contagem E. coli & $<1,0 \mathrm{E}+01$ & $<1,0 \mathrm{E}+01$ & - \\
\hline Contagem de Bolores e Leveduras & $4,2 \mathrm{E}+04$ & $1,4 \mathrm{E}+02$ & - \\
\hline
\end{tabular}

Fonte: Do autor, 2020

Segundo Barros e Carvalho (2011), encontraram resultados semelhantes em trabalho sobre queijo parmesão, no qual os autores avaliaram a microbiologia do queijo parmesão durante o período de maturação e também atendendo a legislação vigente.

Aguilar (2014) analisou a microbiologia de 60 amostras de queijo parmesão ralado encontrando Staphylococcus spp., com populações que variaram de 1,2E+03 UFC.g ${ }^{-1}$ a 8,7E+06 UFC.g-1 ${ }^{-1}$, sendo que $60,0 \%$ dessas apresentaram Estafilococos coagulase positivo e 52,5\% delas com populações acima do limite estabelecido pela legislação. A presença de E.coli foi identificada em 57,5 \% e 6,6 \% das amostras, respectivamente.

Analisando a contagem de bolores e leveduras (Tabela 1), observa-se há uma significativa diferença na redução de microrganismos entre a amostra acondicionada na embalagem $\mathrm{A}$ e na embalagem $\mathrm{B}$. $\mathrm{Na}$ amostra inserida na embalagem A, o queijo tipo parmesão ralado apresentou $42000 \mathrm{UFC} / \mathrm{g}$, esse valor está relacionado a estocagem e as características próprias do alimento que possui grande sensibilidade a diferentes temperaturas e fácil degradação. Enquanto a amostra inserida na embalagem B teve influência direta do aditivo antimicrobiano e apresentou valores de $140 \mathrm{UFC} / \mathrm{g}$ e considerando que a amostra possuía as mesmas características físico-química próprias do alimento fica evidente a ação do ativo e sua eficácia no combate ao crescimento microrganismos causadores de bolores e leveduras. Aguilar (2014) em seu trabalho encontrou resultados em relação as populações de bolores e leveduras de $<10$ a 1,8E+06 UFC.g-1 ${ }^{-1}$, resultados que dependem também da qualidade do leite utilizado no preparo do queijo parmesão.

Tais resultados avaliados tanto para amostra acondicionada na embalagem A quanto para amostra acondicionada na embalagem B, são inferiores aos reportados pelos autores Nunes, et al, (2014). Já segundo Zacarchenco, et al. (2011), em seu estudo sobre bolores e leveduras em queijos, no qual cita que Silva, et al. (2010) coletaram amostras de queijo de coalho em três laticínios do sertão de Alagoas e, dentre as várias análises que realizaram, destaque para as contagens de bolores e leveduras que ficaram próximas de $10^{4} \mathrm{UFC} / \mathrm{g}$ nas amostras de queijo dos três laticínios. A elevada população de bolores e leveduras observada em ambos os queijos indicou deficiência nos procedimentos de higiene e sanitização e os caracterizam como produto em condições higiênicas insatisfatórias.

Segundo Magri e Shittler (2014) o aditivo antimicrobiano foi testado em embalagens para uso em cortes de frangos congelados e também apresentou resultados satisfatórios nas análises microbiológicas, onde obteve maior redução na contagem de bactérias ácido láticas após 11 dias de armazenamento do produto refrigerado.

A embalagem antimicrobiana apresentou uma possível ação na inibição do crescimento de bolores e leveduras, porém ainda são necessários mais testes em larga escala e com outros aditivos inibidores de microrganismos. 


\section{CONCLUSÕES}

A utilização do aditivo microbiano apresentou influência significativa na inibição do crescimento microbiano, sendo mais evidente para bactérias, bolores e leveduras. 0 crescimento de bolores e leveduras da amostra A evidencia que o produto após processamento, sem a ação de aditivos antimicrobianos apresentou como resultado o crescimento natural de microrganismos.

A utilização do aditivo 19244-AN - MB na amostra B comprova que sua ação promissora quando adicionada na embalagem, e que o processo de extrusão utilizado para adesão do ativo na embalagem não interferiu no seu mecanismo de ação. O mesmo atuou diretamente no alimento e na deterioração dos microrganismos causadores de bolores e leveduras, quando em contato na superfície da embalagem, melhorando de forma significativa a qualidade e o shelf life do produto, porém ainda são necessários mais estudos.

\section{REFERÊNCIAS}

[1] Aguilar, C. E. G. (2014). Queijos tipo parmesão ralados industrialmente e no ato da venda, adquiridos no comércio varejista, como fontes de agentes deteriorantes e patogênicos (Dissertação de mestrado). UNESP, Jaboticabal.

[2] Barros, J.; Carvalho, J. (2014). Queijo Parmesão: caracterização físico-química, microbiológica e microestrutura. Ciência e Tecnologia de Alimentos, 31(2), 285-294.

[3] Brasil, Agência Nacional de Vigilância Sanitária (2001). Estabelecer os Padrões Microbiológicos Sanitários para Alimentos. (Resolução-RDC no 12, de 02 de janeiro de 2001). Diário Oficial da República Federativa do Brasil.

[4] Brasil, Ministério da Agricultura e Abastecimento (1997). Regulamento técnico para fixação de identidade e qualidade de queijo ralado (Portaria n 357, de 4 de setembro de 1997). Diário Oficial da República Federativa do Brasil.

[5] Borges, L. R. (1999). Análise de Qualidade Microbiológica (bolores e leveduras) em erva-mate (ilex paraguariensis st. hilj e identificação dos fungos potencialmente micotoxigênicos (Monografia). Universidade Federal do Paraná, Curitiba.

[6] Capelezzo, A. P., Mohr, L. C., Dalcanton, F., Barreta, C. R. D. M., Martins, M. A. P. M., Fiori, M. A., Mello, J. M. M. (2018). Polímero biodegradável antimicrobiano através da aditivação com compostos à base de zinco. Química Nova. 41(4) 367-374.

[7] Sarantópoulos, C. I. G. L., Oliveira, L. M., Canavesi, É. (2001). Requisitos de Conservação de Alimentos em Embalagens Flexíveis. Campinas: CETEA/ITAL, 1(1), 175-182.

[8] Magri, K.; Schittler, L. (2014) Caracterização de propriedades físicas de embalagens de polietileno e sua influência na vida útil de cortes de frango resfriado (Monografia). Universidade Estadual de Santa Catarina, Pinhalzinho.

[9] Nunes, A. C. M., Paiva, J. E., Cortez, N. M. S., Nóbrega, I. C. C., Simões, R. O. (2015). Qualidade Físico-Química e Microbiológica de Queijos Ralados Comercializados em Recife-PE, Brasil. Journal of bioenergy and food science, 02 (1), 25-31.

[10] Pereira, S. G. F; Monteiro, P. S.; Costa, A. P. R.; Botrel, R. V. B. F (2016). Avaliação da Qualidade de queijo parmesão ralado de diferentes marcas comerciais. Higiene Alimentar, 30 (258), 64-68.

[11] Varella, D. (2018). Gastrenterite por salmonela. Disponível em: https://drauziovarella.uol.com.br/doencas-esintomas/gastrenterite-por-salmonelas/.

[12] Vigilância epidemiológica do estado de São Paulo (2013). Doenças transmitidas por água e alimentos. Disponível em: http://www.saude.sp.gov.br/resources/cve-centro-de-vigilancia-epidemiologica/areas-devigilancia/doencas-transmitidas-por-agua-e alimentos/doc/bacterias/2013listeria_monocytogenes.pdf Zacarchenco, P. B., Trento, F. K. H. S., Spadoti, L. M., Gallina, D. A., Silva-Alves, A. T. (2011).

[13] Bolores e Leveduras em Queijos: Uma revisão sobre a contaminação de queijos por bolores e leveduras, defeitos causados e mecanismos de controle. Revista Leite e Derivados, 129(1), 29-33. 


\section{Capítulo 9}

\section{Produção de xarope hidrolisado de lactose do permeado de soro de leite}

\section{Creciana Maria Endres}

Bruna Seguenka

Sandrini Slongo Fortuna

Maristela Schleicher Silveira

Vandré Barbosa Brião

Vera Maria Rodrigues

Resumo: 0 objetivo do estudo foi obter um xarope por processos de concentração e hidrólise enzimática da lactose do permeado do soro de leite. No processo de produção de concentrado protéico, tem-se a origem de um subproduto que é o permeado, rico em lactose e sais, possibilitando a elaboração de um xarope de açúcares com potencial aplicação em produtos alimentícios. A elaboração do xarope ocorreu por processo de tratamento da lactose concentrada, por meio de hidrólise enzimática (concentração $0,1 \%(\mathrm{v} / \mathrm{v}))$. Os resultados demonstraram teor de hidrólise adequado $(<0,1 \%)$, considerado um produto com baixo teor de lactose, benéfico à população que apresenta intolerância. Esse xarope com alto poder adoçante e qualidades tecnológicas desejáveis como viscosidade e solubilidade em água pode ser aplicado na produção de alimentos diferenciados na substituição da sacarose, trazendo alternativas de reutilização do subproduto permeado da ultrafiltração, tornando-se uma alternativa viável para o setor lácteo.

Palavras-Chave: Subproduto; Hidrólise; Indústria Láctea. 


\section{INTRODUÇÃO}

A indústria de laticínios encontra-se em constante crescimento no Brasil e com isso ocorre o aumento da produção de soro de leite. Em 2017 a indústria láctea gerou 2,7 milhões de toneladas de soro (Silva et al., 2017). Grande parte deste subproduto é destinado à alimentação animal ou descartado de forma indevida. Com isso surge a necessidade e a oportunidade de otimizar esse subproduto rico em proteína e lactose. Novas alternativas estão sendo estudadas, como por exemplo, a separação, dos componentes presentes neste fluído, por membranas. Esse processo possibilita a recuperação e a concentração das proteínas do soro, para a obtenção de whey protein (Baldasso, 2008).

A separação dos constituintes do soro de leite, pela tecnologia de separação por membranas, apresenta resultados positivos quanto a separação, concentração e purificação dos constituintes. 0 soro submetido ao processo de ultrafiltração, permite a recuperação das proteínas e, a corrente que permeia a membrana de ultrafiltração, denominada de permeado da ultrafiltração, permite a recuperação de lactose e dos sais. Para concentrar e purificar este permeado, ele é submetido ao processo de nanofiltração seguida de dialise, originando a lactose concentrada, com possível aplicação em formulações alimentícias, como em produtos panificados e balas, além de ser utilizada, quando pura, pela indústria farmacêutica (Baldasso et al., 2011; Faedo et al., 2013, Almeida et al., 2015; Souza et al., 2010).

A lactose concentrada, obtida por processos de concentração, ainda apresenta pouca aplicação industrial. Portanto, processos de hidrólise deste dissacarídeo, são capazes de gerar produtos de maior valor agregado. 0 processo de hidrólise e concentração desses açúcares representa um processo tecnológico rentável para a indústria alimentícia, pois possibilita a elaboração de xaropes com alto poder adoçante, está pode substituir a sacarose usualmente empregada em alimentos. Diante disso, o objetivo do trabalho foi obter xaropes por processos de concentração e hidrólise enzimática da lactose do permeado do soro de leite.

\section{MATERIAL E MÉTODOS}

O soro de leite fluído desnatado e pasteurizado foi cedido pela empresa Relat de Estação/RS. Este foi transportado sob refrigeração $\left(0^{\circ} \mathrm{C}\right)$ em embalagens plásticas térmicas até a Universidade de Passo Fundo, sem sofrer aquecimento. Ao chegar ao laboratório foi mantido sob refrigeração $\left(0{ }^{\circ} \mathrm{C}\right)$ e após foi submetido a separação dos seus constituintes por processos de separação por membranas.

\subsection{PRODUÇÃO DA LACTOSE CONCENTRADA}

O soro de leite foi processado através das operações de ultrafiltração, dando origem ao permeado da ultrafiltração (UF). 0 permeado da UF foi processado pelas etapas combinadas de nanofiltração (NF) e diálise (DF) com objetivo de originar a lactose concentrada (LC). A ultrafiltração foi necessária para separar as proteínas de maior peso molecular e originar uma corrente líquida, o permeado, que era uma solução rica em lactose e sais, mas com baixo teor de proteína, este de interesse para nosso estudo.

Os sais presentes na solução de lactose foram separados da lactose pela operação de nanofiltração, permeando o sódio e o potássio e concentrando a lactose, tendo como retido da membrana, uma solução rica em lactose e alguns sais residuais. Para retirada dos sais remanescentes da solução de lactose realizou-se a operação de diálise, obtendo-se uma solução concentrada em lactose, aqui denominado de lactose concentrada (LC), que foi utilizado como matéria prima nos experimentos deste trabalho.

\subsection{TRATAMENTO DA LACTOSE CONCENTRADA}

A lactose concentrada foi armazenada em embalagens plásticas hermeticamente fechadas, submetidas ao congelamento lento $\left(-18^{\circ} \mathrm{C}\right)$ em freezer, até o momento dos experimentos, não ultrapassando o período de seis meses de estocagem. Antes do congelamento uma amostragem foi retirada para a realização de análises físico-químicas a fim de realizar sua caracterização, através da metodologia de Espectroscopia no infravermelho próximo (FTIR), baseado na legislação Internacional Standard 141 IDF (2013), determinando-se gordura, proteínas, lactose, sólidos totais, sólidos solúveis e pH. 
No momento dos experimentos, a lactose concentrada foi previamente descongelada em refrigerador a $4^{\circ} \mathrm{C}$. Posteriormente foi aquecida a $35^{\circ} \mathrm{C}$ em chapa aquecedora, sob leve agitação para completa solubilização dos sólidos que foram precipitados pelo processo de congelamento. Após, foi filtrado em papel qualitativo para remoção do material precipitado. 0 filtrado foi novamente tratado termicamente a $80^{\circ} \mathrm{C}$, em chapa aquecedora por $20 \mathrm{~min}$, para desnaturação e precipitação das proteínas residuais e após, foi centrifugado a $3000 \mathrm{rpm}$ por $20 \mathrm{~min}$., em centrífuga de tubos (Presvac) para completa separação do precipitado. 0 precipitado foi descartado e o líquido translucido utilizado. A lactose concentrada foi caracterizada quanto ao teor de lactose, gordura, proteínas, sólidos totais, sólidos solúveis e pH pela metodologia de Espectroscopia no infravermelho próximo (FTIR).

\subsection{OBTENÇÃO DO XAROPE}

A hidrólise da lactose concentrada foi realizada com o uso da enzima $\beta$-galactosidase na concentração de $0,1 \%(\mathrm{v} / \mathrm{v})$, em erlenmeyers contendo $200 \mathrm{~mL}$ de xarope de lactose cuja temperatura foi ajustada e mantida constante em $37^{\circ} \mathrm{C}$ utilizando banho-maria dotado de sistema de agitação (Tecnal TE-0532) a $200 \mathrm{rpm}$ por 4 horas. 0 pH do meio reacional foi ajustado em 6,6 através de uma solução de hidróxido de potássio (1 mol.L-1).

0 xarope hidrolisado foi posteriormente concentrado para reduzir o teor de água. A concentração do xarope hidrolisado foi realizada em evaporador rotativo (Fisatom-801), até obter um xarope com teor de sólidos próximos de $80^{\circ}$ Brix. 0 aumento do teor de sólidos totais do xarope foi acompanhado utilizando refratômetro digital (Atago) devidamente calibrado. A temperatura do banho de aquecimento no evaporador rotativo foi de $90^{\circ} \mathrm{C}$, vácuo de $500 \mathrm{mmHg}$ e tempo de concentração em torno de três horas.

\section{RESULTADOS E DISCUSSÃO}

A lactose concentrada obtida preliminarmente por processos de separação por membranas, apresentou uma separação de fases, gerando certa quantidade de precipitado de cor esbranquiçado. A origem deste precipitado pode estar associada à desnaturação das proteínas remanescentes no processo de separação por membranas e devido ao aquecimento aplicado a lactose concentrada. A retirada destes sólidos foi importante para evitar arenosidade no produto final.

\subsection{CARACTERIZAÇÃO DA LACTOSE CONCENTRADA}

A Tabela 1 apresenta a caracterização da lactose concentrada por meio do processo de separação por membranas, antes e após o tratamento.

Tabela 1 - Caracterização lactose concentrada antes e após o tratamento

\begin{tabular}{|c|c|c|}
\hline Análise & $\begin{array}{l}\text { Lactose Concentrada } \\
\text { Antes do tratamento } \\
\text { Média } \pm \text { desvio padrão }\end{array}$ & $\begin{array}{l}\text { Lactose Concentrada Após o } \\
\text { tratamento } \\
\text { Média } \pm \text { desvio padrão }\end{array}$ \\
\hline Lactose (\%) & $12,94 \pm 0,10^{a}$ & $12,30 \pm 0,04^{\mathbf{b}}$ \\
\hline Lípidios (\%) & $0,14 \pm 0,02^{a}$ & $0,07 \pm 0,01^{b}$ \\
\hline Sólidos Totais (\%) & $14,62 \pm 0,06^{a}$ & $14,17 \pm 0,02^{\mathbf{b}}$ \\
\hline Proteína (\%) & $0,63 \pm 0,0 \mathrm{a}$ & $0,61 \pm 0,0^{\mathbf{b}}$ \\
\hline Sólidos Solúveis (Brix) & $15,2 \pm 0,00^{a}$ & $15,2 \pm 0,00^{a}$ \\
\hline $\mathrm{pH}$ & $5,2 \pm 0,00^{a}$ & $5,2 \pm 0,00^{a}$ \\
\hline
\end{tabular}

Os resultados expressam a média \pm desvio padrão. Letras iguais na mesma linha não diferem significativamente pelo Teste Tukey $(\mathrm{P}>0,05)$

Mantiveram-se constantes os teores de sólidos solúveis e pH. Para os demais parâmetros observa-se que uma leve redução em alguns parâmetros após o tratamento, principalmente para a gordura que foi reduzida após as etapas de centrifugação e filtração. Foi observado um residual de sódio nas amostras, isso ocorreu porque o sódio tem capacidade de permear na membrana de NF, sabe-se que neste processo não é possível reduzir $100 \%$ do sódio, no produto. Segundo Salehi (2014) a permeação máxima de íons monovalentes pela membrana de NF é de $80 \%$, além disso, essa quantidade de sais torna um produto com 
características importantes, pois pode ser aplicado em alimentos, tornando-o com valor nutricional superior (Cuartas-uribe et al., 2009). Esses resultados corroboram com os da literatura (Andrade, et al.2013). Através desta caracterização foi possível verificar a alta concentração de lactose, o que já era esperado devido o processo tecnológico utilizado, justificando sua utilização para a elaboração de um xarope.

\subsection{CARACTERIZAÇÃO DO XAROPE}

A Tabela 2 apresenta a caracterização do xarope

Tabela 2 - Caracterização do xarope

\begin{tabular}{|l|c|}
\multicolumn{1}{c|}{ Análise } & Média $\pm \mathrm{DP}$ \\
\hline Umidade (\%) & $12,41 \pm 0,33$ \\
\hline Proteína (\%) & $0,48 \pm 0,04$ \\
\hline Cinzas (\%) & $1,16 \pm 0,00$ \\
\hline Carboidratos (\%) & $85,95 \pm 0,38$ \\
\hline Calorias (kcal/100g) & $345,72 \pm 1,35$ \\
\hline Acidez (D) & $10,41 \pm 0,34$ \\
\hline pH & $6,7 \pm 0,00$ \\
\hline EST $^{*}(\%)$ & $87,59 \pm 0,33$ \\
\hline ESD $^{* *}(\%)$ & $87,59 \pm 0,33$ \\
\hline Sódio (mg/L) & $2600 \pm 0,00$ \\
\hline
\end{tabular}

O xarope obtido a partir do processo de hidrólise e concentração da de lactose, obteve-se um teor de hidrólise adequado $(<0,1 \%)$. Escobar et al., (2014) estudou a hidrólise no permeado de soro diluído com teor de lactose de 5\%, e obteve uma hidrólise de $95 \%$ da lactose, essa diferença pode estar associada ao tempo e temperatura utilizados na hidrólise e as características de cada produto. 0 xarope apresentou alto teor de sólidos, baixa umidade e um pequeno residual de proteína. Esta proteína é remanescente das etapas de separação de membranas que não retiveram totalmente as proteínas e sugere-se que sejam proteínas de menor massa molar.

Duarte (2010) caracterizou o mel comercial Karo®, que apresentou pH de 4,05 e sólidos solúveis de $80^{\circ}$ Brix, sendo diferente do encontrado no presente estudo, estas diferenças se referem às matérias primas utilizadas. 0 xarope atendeu os requisitos exigidos pela Legislação vigente para a classe de alimentos "Xaropes e Produtos de Confeitaria", sendo que apresentou ausência para salmonella e $<1$ UFC/g para coliformes a $45^{\circ} \mathrm{C}$. Estes resultados demonstram que as condições de segurança e higiene foram seguidas e atendidas durante o processo de produção do xarope hidrolisado e concentrado.

\section{CONCLUSÃO}

O processo experimental sugerido para obtenção do xarope, poderá ser reproduzido em escala industrial, trazendo rentabilidade a indústria e aplicabilidade no desenvolvimento de novos produtos. 0 processo de hidrólise é uma alternativa para redução do teor de lactose no produto, podendo ser aplicado a alimentos que fazem parte de dietas com restrições a lactose. Além disso, o xarope pode ser aplicado em formulações, como substituto da sacarose, tendo em vista que está previsto uma redução gradual de 144,6 mil toneladas de sacarose no setor alimentício, até 2022. Este estudo permitiu visualizar a agregação de valor ao subproduto lácteo, aplicação deste na indústria alimentícia, bem como competitividade da indústria. 


\section{REFERÊNCIAS}

[1] Almeida, K. E.; Bonassi, I. A.; Roça, R. O. Características físicas e químicas de bebidas lácteas fermentadas e preparadas com soro de queijo minas frescal. Ciênc. Tecnol. Aliment., v.21, p.187-192, 2001.

[2] Baldasso, C.; Barros, T. C.; Tessaro, I. C. Concentration and purification of whey proteins by ultrafiltration. Desalination, v. 278, n. 1-3, p. 381-386, 2011.

[3] Brião, V. B.; Magoga, J.; Hemkemeier, M.; Brião, E. B.; Girardelli, L.; Sbeghen, L.; Favaretto, D. P. C. Reverse osmosis for Desalination of water from the Guarani Aquifer system to produce drinking water in southern Brazil. Desalination, v. 344, p. 402-411, 2014.

[4] Carminatti, C. A. Ensaios de hidrólise enzimática da lactose em reator a membrana utilizada Beta-galactosidase Kluyveromyces lactis. Dissertação (Mestrado em Engenharia Química), Universidade Federal de Santa Catarina, Florianópolis/SC, 2001.

[5] Cuartas-uribe, B.; Alcaina-miranda, M.I.; Soriano-costa, E.; Mendoza-roca, J.A.; Iborra-clar, M.I., Lora-garcía, J. A study of the separation of lactose from whey ultrafiltration permeate using nanofiltration. Desalination, v. 241, p. 244255, 2009.

[6] Escobar, G. P., Souza, C. F. V., Lehn, D. N., Avaliação de $\beta$-galactosidase livre e imobilizada na hidrólise da lactose do permeado de soro de queijo. Centro de Ciências Biológicas e da Saúde, Centro Universitário UNIVATES. Caderno pedagógico, Lajeado, v. 11, n. 1, p. 117-129, 2014.

[7] Faedo, R., Brião, V. B., Castoldi, S., Girardelli, L., Milani, A., Obtenção de leite com baixo teor de lactose por processos de separação por membranas associados à hidrólise enzimática. Universidade de Passo Fundo, Revista CIATEC - UPF, vol.3, p.p.44-54, 2013.

[8] Klein, M. P. Imobilização de $\beta$-galactosidase para obtenção de produtos lácteos com baixo teor de lactose. Dissertação (Mestrado em Ciência e Tecnologia de Alimentos), Universidade Federal do Rio Grande do Sul/RS 2010.

[9] Salehi, F. Current and future applications for nanofiltration technology in the food processing. Food and Bioproducts Processing, v.92, p.161-177, 2014.

[10] Silva, R. O.P., Bueno, C. R. F., Sá, P. B. Z. R. Aspectos relativos à produção de soro de leite no brasil, 2007-2016. Informações Econômicas, v. 2, n. 2, 2017.

[11] Souza, R. R.; Bergamasco, R.; Costa, S. C.; Feng, X.; Faria, S. H. B.; Gimenes, M. L. Recovery and purification of lactose from whey. Chemical Engineering and Processing: Process Intensification, v. 49, p. 1137-1143, 2010. 


\section{Capítulo 10}

Desenvolvimento, composição nutricional e funcional de suco misto de açaí (Euterpe oleracea Mart.) e acerola (Malpighia glabra L.)

Silvia Regina Magalhães Couto Garcia

\section{Carolina Pinto de Carvalho Martins}

Gabriella Araújo Rebouças Oliveira

Bruna Oliveira de Araújo

Resumo: $\mathbf{O}$ açaí e a acerola apresentam grande concentração de compostos bioativos que possuem como função biológica a ação contra radicais livres. 0 objetivo foi desenvolver um suco misto a partir da polpa de açaí comercial tipo B e acerola, e realizar sua caracterização físico-química e funcional. As determinações realizadas foram umidade, resíduo mineral fixo, acidez titulável total, ํㅗix, pH, proteína, fibra insolúvel e solúvel, lipídios, carboidratos, compostos fenólicos totais, vitamina C, antocianinas totais e atividade antioxidante. Dentre os testes, foram obtidos os seguintes teores: umidade $(86,16 \mathrm{~g} / \%)$, RMF (0,36g/\%), acidez (0,55g/\%), ํBix $\left(10^{\circ}\right)$, pH (4,17), proteínas $(0,47 \mathrm{~g} / \%)$, fibra totais $(3,15 \mathrm{~g} / \%)$, Lipídios $(1,79 \mathrm{~g} / \%)$, carboidratos $(6,96 \mathrm{~g} / \%)$, compostos fenólicos (130,43mg ácido gálico/L), vitamina C (56mg/100g), antocianinas totais $(75,78 \mathrm{mg} / 100 \mathrm{~g})$ e atividade antioxidante $(1,03 \mathrm{~g}$ fruta/mg DPPH ou $87,56 \%$ de sequestro do radical livre). Os efeitos benéficos de produtos com componentes bioativos só serão eficazes no organismo humano quando associados a hábitos de vida saudável.

Palavras-Chave: açaí; acerola; compostos bioativos. 


\section{INTRODUÇÃO}

O açaí (Euterpe oleracea M.), espécie nativa da Amazônia e a acerola (Malpighia glabra L.), originária das Antilhas, América Central e norte da América do Sul, apresentam em comum a presença dos compostos fenólicos bioativos (CBAs), destacando-se o grupo dos flavonóides (antocianina e epigalocatequinas) (Ribeiro et al., 2010).

Já é reconhecida a relação entre ingestão de frutos e vegetais, e a diminuição do risco de desenvolvimento dessas doenças crônico-degenerativas mediadas pela ação de radicais livres. Esses alimentos contêm grande concentração de compostos bioativos que possuem como função fisiológica, a ação contra radicais livres (Avello e Suwalsky, 2006).

A acerola tem como seu principal atrativo o alto teor de vitamina $C$, sendo também rica em outras vitaminas como, tiamina, riboflavina e niacina, além de carotenóide (Assis et al., 2001). Industrialmente, existem vários produtos alimentícios de acerola, sendo a fruta in natura, a polpa congelada e o suco engarrafado as formas mais comuns de comercialização. Mesquita e Vigoa (2000) ressaltaram que o alto teor de vitamina $\mathrm{C}$ da acerola e a presença de antocianinas, destacam este fruto no campo dos nutracêuticos, pela habilidade desses compostos em capturar radicais livres no organismo humano.

Já o açaí, além da forma tradicional de consumo, também é muito utilizado na produção industrial ou artesanal de sorvetes. A polpa concentrada do fruto é rica em minerais e flavonóides, destacando-se dentre estes as antocioaninas, pigmentos responsáveis por sua cor violácea e ação antioxidante que pode prolongar a vida das células, aumentar as defesas imunitárias e proteger o organismo contra o acúmulo de lipídeos nas artérias (Rogez, 2000).

O hábito do consumo de sucos de frutas e hortaliças processados tem aumentado, motivado pelo estilo de vida da população que dificulta o preparo com o fruto in natura e pela praticidade oferecida pelos produtos processados (Ramosi et al., 2012). Além disso, a preocupação com o consumo de alimentos mais saudáveis vem aumentando, e com isso existe uma tendência pela substituição do consumo de bebidas carbonatadas pelos sucos de fruta.

O suco misto é definido como o suco obtido pela mistura de duas ou mais frutas e das partes comestíveis de dois ou mais vegetais, ou dos seus respectivos sucos, sendo a denominação constituída da palavra suco, seguida da relação de frutas e vegetais utilizados, em ordem decrescente de quantidades presentes na mistura (Brasil, 2003).

O objetivo do estudo foi desenvolver um suco misto a partir da polpa de açaí comercial tipo B e acerola, e realizar sua caracterização físico-química e funcional.

\section{MATERIAIS E MÉTODOS}

A polpa de açaí (Euterpeoleracea) tipo B, foi obtida congelada na Central de Abastecimento do Rio de Janeira (CEASA-RJ). A acerola (Malpighia glabra) foi adquirida na forma de fruta in natura através de doação por agricultor familiar, a fruta foi higienizada e batida em liquidificador obtendo-se uma polpa.

Para o preparo do suco misto foi utilizada $50 \%$ de polpa de açaí, $25 \%$ de polpa de acerola, $17,5 \%$ água e $7,5 \%$ de sacarose. 0 suco obtido foi separado em 3 alíquotas de $300 \mathrm{~mL}$ que foram acondicionadas em congelador no Laboratório de Processamento de Frutas e Hortaliças do Instituto de Nutrição Josué de Castro (INJC) - UFRJ até a realização da análises.

Para a caracterização físico-química do suco misto, foram realizadas as determinações de umidade, resíduo mineral fixo, acidez titulável total, sólidos solúveis totais, $\mathrm{pH}$, proteína, fibra insolúvel e solúvel de acordo com as metodologias propostas pelo Instituto Adolfo Lutz (2005). A determinação de lipídios foi realizada de acordo com a metodologia proposta por Bligh e Dyer (1959). A quantificação de carboidratos foi representada pela fração NIFEXT, obtida por diferença entre 100 e o somatório dos teores de umidade, proteínas, lipídeos, fibras e resíduos minerais fixos. Considera-se como carboidratos totais os monossacarídeos, dissacarídeos e amidos da amostra.

Para a caracterização funcional foi realizada a determinações dos compostos fenólicos totais, cujo resultado foi expresso em mg de EAG (equivalentes de ácido gálico) por $100 \mathrm{~g}$ de amostra, e vitamina C, ambos segundo metodologia proposta por George et al. (2005). A leitura do comprimento de onda foi realizada em absorbância de $760 \mathrm{~nm}$. 
As antocianinas totais foram realizadas pelo método $\mathrm{pH}$ diferencial segundo metodologia proposta por Giusti \& Wrolstad (2001) e adaptada por Klopotek et al. (2005). 0 resultado foi expresso em equivalente da antocianina principal, cianidina-3-glucosídeo. Para a quantificação das antocianinas foram consideradas as absorbâncias a 510 e 700 nm das amostras diluídas na solução tampão pH 1,0 e 4,5.

Para determinação do potencial antioxidante foi utilizado o método DPPH descrito por Brand-Williams et al. (1995) e adaptado por Rufino et al. (2010). 0 radical livre (2,2-difenil-1-picril-hidrazil) reage com um composto antioxidante, as alterações de cor vão do violeta para amarelo-claro. A leitura do comprimento de onda foi realizada em absorbância de $515 \mathrm{~nm}$. Para todas as leituras em espectrofotômetro foi utilizado o equipamento Spectrophotometer Biospectro SP-220.

\section{RESULTADOS E DISCUSSÃO}

Os valores encontrados para a caracterização físico-química do suco misto são descritos na tabela 1.

Tabela 1. Caracterização físico-química do suco misto

\begin{tabular}{|l|c|}
\multicolumn{1}{|c|}{ Componente químico } & Média e Desvio Padrão \\
\hline Umidade (g/\%) & $86,16 \pm 0,11$ \\
\hline Cinzas (g/\%) & $0,36 \pm 0,03$ \\
\hline Proteínas (g/\%) & $0,47 \pm 0,00$ \\
\hline Lipídios (g/\%) & $1,79 \pm 0,00$ \\
\hline Fibras Solúveis (g/\%) & $1,21 \pm 0,26$ \\
\hline Fibras Insolúveis (g/\%) & $3,06 \pm 0,18$ \\
\hline Carboidratos (g/\%) & $6,96 \pm 0,23$ \\
\hline Kcal & $45,78 \pm 2,10$ \\
\hline pH & 4,17 \\
\hline Acidez (g de ácido cítrico/100g) & $0,54 \pm 0,01$ \\
\hline o-Brix & 10 \\
\hline
\end{tabular}

O Decreto no 3.510, que modifica o inciso III, do Art. 40, do Decreto no 2.314, estabelece que ao suco poderá ser adicionado açúcar na quantidade máxima fixada para cada tipo, através de ato administrativo, obedecendo ao percentual máximo de 10\%, calculado em g açúcar/100g de suco (MAPAR, 2000). A concentração de sólidos solúveis expressa em graus Brix foi limitada a 10ํㅡㄹ respeitando o máximo de açúcar da legislação, utilizando 7,5\% de sacarose ao suco misto apenas para ajuste do Brix.

0 teor de acidez total expressa em ácido cítrico $(\mathrm{g} / 100 \mathrm{~g}$ ) deve ser no mínimo 0,8 para polpa acerola e no máximo de 0,45 polpa para açaí (Brasil, 2000), com isso o suco misto apresentando 0,54 está próximo aos valores estabelecidos pela legislação

0 valor de $\mathrm{pH}$ de 4,7 considera o produto ácido ( $\mathrm{pH}<4,6)$, segundo Franco \& Landgraf (1996), coloca-se entre os menos sujeitos à contaminação microbiana, tanto de espécies patogênicas e possíveis de crescimento de bolores e leveduras.

0 teor de cinzas de $0,36 \%$ se deve as concentrações significativas de enxofre, cálcio e ferro presente no açaí, e este valor está de acordo para polpa de açaí tipo médio encontrados por Vaz (2003). Naturalmente, o açaí e a acerola apresentam baixos teores de proteínas, e na bebida que é diluída, foi possível observar teores esperados de $0,47 \mathrm{~g} / 100 \mathrm{~g}$.

0 açaí é um alimento altamente calórico devido ao alto percentual em matéria graxa, seu principal nutriente. Produtos contendo polpa desse fruto terão valores significativos de lipídios, como mostrado na Tabela 1, o resultado obtido foi de 1,79\%. Segundo Rogez (2000), o ácido oléico é o mais abundante (54,9\%), seguido dos ácidos palmítico $(25,9 \%)$ e linoléico, porém apresentando reduzido teor em ácido linolênico (Yuyama et al., 2004). 0 alto teor de ácidos graxos mono e poliinsaturados implica, certamente, na sua fácil oxidação, o que contribui para uma possível rancificação rápida da bebida. 
A bebida apresentou em sua composição alto teor de fibras, componente alimentar com alegação de propriedade funcional. A quantidade de fibras totais encontrada foi de 4,27\%, 3,06\% para as insolúveis e 1,21\% para as solúveis. Esse valor está de acordo com o encontrado por Rogez (2000), 3,15 g de fibras totais/100 ml de açaí médio (tipo B). As fibras solúveis propiciam maior volume do bolo alimentar, maior sensação de saciedade, aumento da viscosidade das soluções no trato gastrointestinal, retardando o esvaziamento gástrico de refeições ricas em carboidratos, reduzindo assim a resposta glicêmica (Janebro et al.; Souza et al., 2008). As fibras insolúveis podem atuar no aumento do volume das fezes, auxiliando no controle da constipação intestinal (Souza et al., 2008).

0 resultado obtido para o teor de compostos fenólicos foi de 130,43mg/100g para o suco misto. Segundo Kuskoski (2006), para polpa de açaí, os resultados de compostos fenólicos foram de 136,8mg/100g, e para a polpa de acerola $580,1 \mathrm{mg} / 100 \mathrm{~g}$. Isso evidência que o suco que contém $50 \%$ de açaí e $25 \%$ de acerola possui alto teor de compostos bioativos antioxidantes.

Segundo Bobbio et al. (2000), no açaí as antocianinas foram identificadas como cianidina-3-arabinosídeo e cianidina-3-arabinosil-arabinosídeo, sendo o teor de antocianinas totais na casca do fruto de 263 $\mathrm{mg} / 100 \mathrm{~g}$. A quantificação demonstrou $75,78 \mathrm{mg}$ de antocianinas totais/ $100 \mathrm{~g}$ do suco misto que contém $50 \%$ de polpa de açaí. 0 teor de antocianinas de açaí é mencionado na literatura, os dados divergem bastante entre si, principalmente dada à terminologia empregada referenciando o açaí como o fruto, propriamente dito, e não a bebida. Além disso, a quantificação dos pigmentos também contribui para tamanha diferença, e ainda a ampla variabilidade das matérias-primas, especialmente, quanto à sazonalidade e à região produtora (Constant, 2003). A acerola também possui antocianinas, o que contribui para um resultado representativo desse composto na bebida. Durante o processo de fabricação da bebida, há possíveis perdas de antocianinas em decorrência de sua reduzida estabilidade. Pelos resultados obtidos mesmo após a extração, foi possível a obtenção de um produto com teor significativo de antocianinas.

No que se refere à capacidade antioxidante dos extratos, os resultados foram expressos em percentual de sequestro radical DPPH, com $85,6 \%$ ou $1,0270 \mathrm{~g}$ fruta/mg DPPH, esse resultado evidencia-se que o composto ativo presente atua como doador de hidrogênio ao radical, exibindo capacidade de sequestro acima de 70\%, que se encontra em concordância com estudos de Melo et al (2008), que evidenciou alta capacidade de sequestro utilizando polpa de acerola.

\section{CONCLUSÃO}

A caracterização físico-química dos frutos e a quantificação de componentes bioativos são importantes para o conhecimento do valor nutricional e funcional dos alimentos, e do ponto de vista comercial, para agregar valor e qualidade ao produto final. Dentre os compostos com propriedades funcionais em alimentos, substâncias com atividade antioxidante têm recebido grande atenção, pois auxiliam a proteger o organismo humano contra o estresse oxidativo, evitando e prevenindo uma série de distúrbios crônicodegenerativos. Cabe ressaltar, entretanto, que os efeitos benéficos dos componentes bioativos das dietas contendo suco com alto potencial antioxidante só serão eficazes no organismo humano quando associados a hábitos de vida saudável.

\section{REFERÊNCIAS}

[1] Assis, S.A., Lima, D.C. \& Oliveira, O.M.M.F. (2001). Activity of pectin methylesterase, pectin content and vitamin $C$ in acerola fruit at various stages of fruit development. Food Chemistry, v.74, p.133-137.

[2] Avello, M. \& Suwalsky, M. (2006). Radicales libres, antioxidantes naturales y mecanismos de proteccion. Atena, Concepción.

[3] Bobbio, F. O., Druzian, J. I., Abrão, P. A., Bobbio, P. A. \& Fadelli, S. (2000). Identificação e quantificação das antocianinas do fruto do açaizeiro (Euterpe oleracea Mart).

[4] Bligh, E. G. \& Dyer, W. J. (1959). A rapid method of total lipid extraction and purification. Canadian Journal of Biochemistry and Physiology. 37, 911.

[5] Brand-Williams, W., Cuvelier, M.E. \& Berset, C. (1995). Use of Free Radical Methodto Evaluate antioxidant Activity. LWT-Food Science and Technology, 28, 25-30.

[6] Brasil. Ministério da agricultura e Abastecimento (2000). Instrução Normativa n.o 01, de 07 de janeiro de 2000. Aprova padrões de Identidade e qualidade para polpa de açaí. Diário Oficial da República Federal do Brasil. 
[7] Brasil. Ministério da agricultura, pecuária e Abastecimento. (2003). Instrução Normativa n.ำ12, de 4 de setembrode 2003. Art. 1‥Aprovar o Regulamento Técnico para Fixação dos Padrões de Identidade e Qualidade Gerais para Suco Tropical; os Padrões de Identidade e Qualidade dos Sucos Tropicais. Diário Oficial da República Federal do Brasil.

[8] Brasil, Ministério da agricultura, pecuária e abastecimento (2000). Altera dispositivos do Regulamento aprovado pelo Decreto $n^{\circ}$ 2.314, de 4 de setembro de 1997, que dispõe sobre a padronização, a classificação, o registro, a inspeção, a produção e a fiscalização de bebidas. (Decreto nํ 3.510, de 16 de Junho de 2000). Diário Oficial da República Federal do Brasil.

[9] Calixto, F. (1997). Effect of drying temperature on the stabilitity of polyphenols and antioxidant activity of red grape pomace peels. Journal Agriculture and Food Chemistry, v. 45, p. 1390-1393.

[10] Constant, P. B. L. (2003) Extração, Caracterização e Aplicação de antocianinas de açaí (Euterpe oleracea, M.). Tese (Doutorado em Ciência e Tecnologia de Alimentos). Universidade Federal de Viçosa, Viçosa.

[11] Franco, B. D. G. M. \& Landgraf, M. (1996). Microbiologia dos Alimentos. São Paulo, SP: Ed. Atheneu. 182p.

[12] Giusti, M. M. \& Wrolstad, R. E. (2001). Characterization and mesasurement of anthocyanins by UV-visible spectroscopy. In Wrolstad, R.E. (Ed.).Current Protocols in Food Analytical Chemistry. New York: Wiley

[13] Instituto Adolfo Lutz. (2005). Métodos Físico-Químicos para Análise de Alimentos. 4a Ed. V 1. 533p. São Paulo, Brasil.

[14] Janebro, D. I., Queiroz, M. S. R., Ramos, A. T., Sabaa-Srur, A. U. O., Cunha, M. A. L., Oliveira, L.F., Nascimento, M. R. F., Borges, S. V.; Ribeiro, P. C. N. \& Ruback, V. R. (2002). Aproveitamento alternativo da casca do maracujá-amarelo (Passifl ora edulis F. Flavicarpa) para Produção de doce em calda. Ciênc. Tecnol. Alim., Campinas, v.22, n.3, p. 1-60.

[15] Klopotek, Y. \& Otto, K. (2005). Processing strawberries to different products alters contents of vitamin C, total phenolics, total anthocyanins, and antioxidant capacity. J Agric Food Chem.

[16] Kusoski, E. M., Asuero, M. T. \& Fett, R. (2008). Frutos tropicais silvestres e polpas de frutas congeladas: atividade antioxidante, e antocianinas.

[17] Melo, E.A., Maciel, M.I.S., Lima, V.A.G.L. \& Nascimento, R.J. (2008). Capacidade antioxidante de frutas. Revista Brasileira de Ciências Farmacêuticas, São Paulo, v. 44, n.2, p. 193-201.

[18] Mesquita, P.C. \& Vigoa, Y.G. (2000) La acerola. Fruta marginada de Americacon alto contenido de acido ascórbico Alimentaria, v. 37, n. 309, p.113-125.

[19] Ramosi, A. S. F. A. M., Guedes, D. B., Henrique, A. D. N. O. T., de Lima, S. F., \& de Sousa, P. H. M. (2012). Desenvolvimento de um suco misto de manga, goiaba e acerola utilizando delineamento de misturas. Cienc. Rural vol.42 no.5.

[20] Ribeiro, F. E., Barbosa, R. R., Falco, N. D., Praseres, B. A. F., Nunes, R., Maganha, E. G. \& Bassoli, B; K. (2010). Efeitos da ingestão de açaí e da acerola sobre o pico glicêmico de ratos WISTAR.

[21] Rogez, H. (2000) Açaí: Preparo, composição e melhoramento da conservação. Ed Universidade Federal do Pará - EDUPA, Belém, Pará. 360pp.

[22] Rosa, L.A., Alvarez-parrilla, E. \&Gonzalez-Aguilara, G.A. (2010) Fruit and vegetable phytochemicals: chemistry, nutritionalvalueandstability. Hoboken: Wiley-Blackwell, p. 3-51.

[23] Rufino, M.S.S., Alves, R.E., Brito, E.S., Pérez-Jiménez, J., Saura-Calixto, F. and Mancini-Filho, J. (2010) Bioactive Compounds Antioxidant Capacitiesof 18 Non-Traditional Tropical Fruits from Brazil. FoodChemistry, 121, 996-1002.

[24] Souza, M. W. S., Ferreira, T. B. O., Vieira, I. F. R. (2008). Composição centesimal e propriedades funcionais tecnológicas da farinha da casca do maracujá. Alimentos e Nutrição Araraquara, Vol. 19, No 1.

[25] Vaz, A. P. L. (2003). Caracterização e avaliação da qualidade de polpas de açaíindustrializadas e perfil de ácidos graxos do fruto do açaizeiro. (Dissertação de mestrado). Universidade Federal de Pernambuco, Recife.

[26] Yuyama,L. K. O., Aguiar, J. P. L., Melo, T., Barros, S. E., Filho, D. F. S., Yuyama, K., Fávaro, D. I. T., Vasconcellos, M.; Pimentel, S. A. \& Badolato, E. S. G.. Açaí (Euterpe oleracea Mart.): Qual o seu potencial Nutricional? In: XVII Congresso brasileiro de friticulura. Florianópolis. Santa Catarina. 


\section{Capítulo 11}

Desenvolvimento e validação de método utilizando Mekc-Dad para determinação de cafeína e taurina em bebidas energéticas comercializadas no estado de São Paulo

\section{Alane Cangani Alves}

Adriana Dillenburg Meinhart

Adriana Teixeira Godoy

Helena Teixeira Godoy

José Teixeira Filho

Resumo: 0 consumo de bebidas energéticas no Brasil e no mundo tem aumentado a cada ano. As bebidas energéticas estimulam o sistema nervoso central e intensificam a atividade cardíaca, efeitos atribuídos principalmente à cafeína e taurina, principais ingredientes da bebida. A ingestão elevada da bebida pode causar ansiedade, taquicardia e outros sintomas mais graves, o que torna importante o monitoramento do teor de cafeína e taurina a fim de comprovar se os níveis no produto final estão de acordo com a rotulagem e com limites legais vigentes. 0 objetivo deste trabalho foi desenvolver e validar um método rápido e confiável para a determinação simultânea de cafeína e taurina por cromatografia eletrocinética micelar e detector de arranjo de diodos (MEKC-DAD), e aplicar a metodologia em amostras de bebidas energéticas comercializadas no estado de São Paulo, para verificar se o teor de cafeína e taurina está de acordo com os valores declarados nos rótulos e com os limites estabelecidos pela legislação brasileira. Técnicas estatísticas multivariadas como o planejamento composto central e o método de otimização simultânea de Derringer e Suich foram utilizadas para a otimização do método. Os procedimentos multivariados foram eficazes para determinar as condições ideais de separação, usando como respostas de resolução entre cafeína e taurina, assimetria e altura de pico de taurina. Empregou um capilar com bulbo estendido de $50 \mu \mathrm{m}$ d.i. x $72 \mathrm{~cm}$ de comprimento total, eletrólito contendo $16,20 \mathrm{mmol} \cdot \mathrm{L}^{-1}$ de ácido benzóico e $39,90 \mathrm{mmol} \cdot \mathrm{L}^{-1} \mathrm{de}$ SDS, em pH 7,26, voltagem de $+30 \mathrm{kV}$, temperatura de $25{ }^{\circ} \mathrm{C}$, injeção hidrodinâmica a 50 mbar por $5 \mathrm{~s}$ e detecção direta da cafeína a $274 \mathrm{~nm}$ e indireta da taurina a $230 \mathrm{~nm}$. Os parâmetros de validação foram eficientes demonstrando a confiabilidade do método para a aplicação em amostras. Foram analisadas 73 amostras de bebidas energéticas, nas quais a concentração média de cafeína variou entre 16,68 e 34,64 mg. $100 \mathrm{~mL}^{-1}$ e para a taurina variou entre 188,97 e 614,19 mg.100 mL-1. Verificou-se que mais de $50 \%$ das amostras estavam fora dos limites legais determinados pelo governo brasileiro quanto ao teor de taurina e $68 \%$ continham cafeína abaixo do valor declarado no rótulo. Portanto, existe a necessidade de um maior controle quanto à composição dessas bebidas.

Palavras-chave: bebida energética, cafeína, taurina, MEKC-DAD, otimização multivariada, Derringer e Suich. 


\section{INTRODUÇÃO}

A bebida energética surgiu nos anos de 1960 nos continentes Europeu e Asiático, e sua expansão tem sido tão elevada que sua comercialização é considerada como o mercado com o crescimento mais acelerado dentre as demais bebidas não alcoólicas. 0 consumo de bebida energética tem se tornado popular, principalmente, entre o público jovem, especialmente entre estudantes (MALINAUSKAS, 2007; ATTILA; CAKIR, 2011), pessoas fisicamente ativas (TSITSIMPIKOU et al., 2011) e os atletas (BUXTON; HAGAN, 2012).

As bebidas energéticas são classificadas como não alcoólicas e se caracterizam, principalmente, por estimularem o sistema nervoso central e pela ação diurética que ajuda na eliminação de substâncias nocivas ao organismo (CARVALHO, 2006; HECKMAN, 2010).

Segundo a Agência Nacional de Vigilância Sanitária Brasileira a bebida energética é um "Composto Líquido Pronto para o Consumo", podendo apresentar em sua composição os seguintes ingredientes: inositol e/ou glucoronolactona (máximo $20 \mathrm{mg} .100 \mathrm{~mL}^{-1}$ ), e/ou taurina (máximo $400 \mathrm{mg} .100 \mathrm{~mL}^{-1}$ ), e/ ou cafeína (máximo $35 \mathrm{mg} .100 \mathrm{~mL}^{-1}$ ), podendo ser adicionada de vitaminas e/ou minerais (em até $100 \%$ da Ingestão Diária Recomendada-IDR) e outros ingredientes, desde que não haja descaracterização do produto (BRASIL, 2005).

A cafeína e taurina são substâncias adicionadas na maioria das bebidas energéticas. A cafeína é um psicoativo, sendo que no corpo humano apresenta efeito de estimulação do sistema nervoso central, aumento do desempenho físico e mental, do estado de alerta, melhora do estado de humor e das atividades cardíacas no organismo humano (PAULA LIMA \& FARAH, 2019; MCLELLAN ET AL., 2016; BIZZOTO ET AL., 2013; SEIFERT ET AL., 2011; TRABULO, 2011). A cafeína é considerada um dos ingredientes mais comuns presentes a todas as marcas de bebidas energéticas (PAULA LIMA \& FARAH, 2019; TURAK ET AL., 2017; MCLELLAN ET AL., 2016; RAI ET AL., 2016). No entanto, quando ingerida em doses acima de $400 \mathrm{mg} /$ dia (considerando um adulto de $70 \mathrm{~kg}$ ) pode causar ansiedade, insônia, taquicardia, tremor, irritabilidade, entre outros sintomas indesejáveis (MCLELLAN ET AL., 2016; REID ET AL., 2016; TEMPLE, 2019; TRAN ET AL., 2016; TURAK ET AL., 2017). A partir de 1000 mg/dia apresenta toxicidade ao organismo e em quantidades de 5000 a $10.000 \mathrm{mg} / \mathrm{dia}$ /pessoa pode ser letal (SEIFERT et al., 2011).

A taurina é um aminoácido livre que desempenha um papel fundamental em diversas reações metabólicas do organismo humano, absorvendo gorduras, protegendo o coração e atuando como antioxidante (ALZAWQARI ET AL., 2016; CATHARINO ET AL., 2011; GILES ET AL., 2012; GORON \& MOINARD, 2018; HEIDARI ET AL., 2016; MELE ET AL., 2019; PANSANI ET AL., 2012; PEREIRA ET AL., 2012; RAI ET AL., 2016; WEN ET AL., 2019). Além disso, tem função diurética auxiliando na eliminação de substâncias tóxicas ao organismo (DALL'AGNOL, 2009; PANSANI, 2010; TRABULO, 2011; PEREIRA, 2012). Devido as suas funções fisiológicas, a taurina tem sido cada vez mais empregada pelas indústrias de alimentos como um ingrediente funcional em alimentos (QU, 1999; PEREIRA, 2012). Todos estes aspectos explicam porque a taurina é um dos ingredientes principais da composição da bebida energética. Além disso, diversos estudos comprovam que a taurina apresenta um poder ergogênico e proporciona uma melhoria no desempenho físico (PEREIRA, 2012). Em relação à toxicidade, a taurina é geralmente bem tolerada pelo organismo humano, sem quaisquer efeitos fisiológicos adversos. Estima-se que a população mundial consuma cerca de $400 \mathrm{mg}$ por dia (SANCTIS ET AL., 2017) e não há relatos de efeitos colaterais quanto ao uso terapêutico de doses entre 1.000 e 3.000 mg por dia (HECKMAN ET AL., 2010; JAKOPIN, 2019).

Tanto o conteúdo de cafeína quanto de taurina é geralmente determinado por cromatografia líquida de alta eficiência (HPLC) utilizando detector de arranjo de diodos (DAD) (BIZZOTTO ET AL., 2013; CHIRITA TAMPU ET AL., 2018; PAULA LIMA, FARAH, 2019; RAI ET AL., 2016). A eletroforese capilar, principalmente a cromatografia eletrocinética de zona ou micelar (MEKC) com detector de arranjo de diodos (DAD), também é frequentemente empregada. No entanto, a taurina não absorve luz na região do ultravioleta-visível (UV-VIS), sendo assim detectada de forma indiretamente, seja por DAD, ou por fluorescência induzida por laser, ou ainda por detectores amperométricos e condutométricos (RAI ET AL., 2016; SAWABE ET AL., 2008; VOCHYÁNOVÁ ET AL., 2014; ZINELLU ET AL., 2009).

A principal dificuldade no desenvolvimento de um método para análise simultânea de cafeína e taurina consiste exatamente no mecanismo de detecção a ser aplicado. A análise simultânea de dois compostos já foi descrita em estudos que empregaram HPLC com detector por espectrometria de massa (MS) e por MEKC com dois detectores conectados, sendo o DAD para cafeína e o condutométrico para taurina (VOCHYÁNOVÁ ET AL., 2014; WELCH ET AL., 2015). A utilização de dois métodos torna esta análise lenta e trabalhosa, o que destaca a importância do desenvolvimento de métodos com a detecção simples e 
simultânea para os dois compostos. A técnica de eletroforese capilar tem sido cada vez mais utilizada devido à alta resolução, rapidez, baixo custo e baixa geração de resíduos (MEINHART, 2010; BALLUS, 2012; VOCHYANOVA, 2014), razão pela qual esta técnica é uma ferramenta importante para análises como cafeína e taurina.

Assim, o objetivo deste trabalho foi desenvolver, validar e aplicar um método para determinação simultânea do teor de cafeína e taurina, utilizando MEKC-DAD (cromatografia eletrocinética micelar com detector de arranjo de diodos) em bebidas energéticas comercializadas no estado de São Paulo, Brasil.

\section{MATERIAIS E MÉTODOS}

\subsection{AMOSTRAS}

Para o desenvolvimento e validação do método foram adquiridas 03 embalagens de $350 \mathrm{~mL}$ de uma única marca, cuja composição foi considerada a mais complexa em comparação com as demais marcas, levando em consideração as informações apresentadas no rótulo do produto.

Para a avaliação do teor de cafeína e taurina em bebidas energéticas, foram adquiridas 03 embalagens de 22 marcas, obtidas em três lotes diferentes, sendo que 05 marcas foram adquiridas apenas dois lotes por falta de disponibilidade nos supermercados, totalizando 73 amostras. As amostras foram adquiridas em supermercados, em algumas diferentes cidades do estado de São Paulo.

0 preparo das amostras consistiu na homogeneização do conteúdo total das embalagens representantes de cada marca/lote e desgaseificação em ultrassom por 20 minutos e filtragem em filtro Millipore de 0,22 $\mu \mathrm{m}$ (Millipore, EUA), antes da injeção no sistema de eletroforese capilar. Todas as determinações foram feitas em triplicata, sendo que cada replicata representa a média de três injeções.

\subsection{REAGENTES}

O ácido benzóico foi adquirido a Carlo Erba (Cornaredo, Ml, Itália) e o dodecilsulfato de sódio (SDS) a Riedel-de-Haën (Seelze, NI, Alemanha). Os padrões de cafeína e taurina foram adquiridos da Sigma-Aldrich (St. Louis, MO, EUA). Todas as soluções foram preparadas com água ultrapura (sistema Milli-Q® da Millipore Corporation, Jaffrey, $\mathrm{NH}, \mathrm{EUA}$ ) e filtradas em membrana de celulose porosidade de 0,22 $\mu \mathrm{m}$ (Millipore, Jaffrey, NH, EUA). Soluções estoque de cafeína e taurina $\left(500 \mathrm{mg} . \mathrm{L}^{-1}\right.$ e de $5000 \mathrm{mg} . \mathrm{L}^{-1}$, respectivamente), assim como as soluções deste estudo, foram armazenadas a temperatura de refrigeração $\left(4^{\circ} \mathrm{C}\right)$.

\subsection{EQUIPAMENTO}

0 equipamento utilizado foi um sistema de eletroforese capilar Agilent G1600AX (Agilent Tecnologies, Alemanha), equipado com detector de arranjo de diodos (DAD), injetor automático e sistema de controle de temperatura ajustado para $25^{\circ} \mathrm{C}$. Foi utilizado um capilar de sílica fundida com $50 \mu \mathrm{m}$ de diâmetro interno por $72 \mathrm{~cm}$ de comprimento efetivo, com bulbo estendido (Agilent Technologies, Alemanha). A detecção foi realizada nos comprimentos de onda de 230 e $274 \mathrm{~nm}$, para a taurina e cafeína, respectivamente. A análise e o tratamento dos dados foram realizados no software HP ChemStation.

O capilar novo foi ativado e condicionado por lavagem com pressão de 50 mbar, usando uma solução de hidróxido de sódio 1 mol. $\mathrm{L}^{-1}$ durante $30 \mathrm{~min}$, seguido de $10 \mathrm{~min}$ de água. No início de cada dia de trabalho, o capilar foi condicionado durante $5 \mathrm{~min}$ com hidróxido de sódio $1 \mathrm{~mol} . \mathrm{L}^{-1}$, seguido de 5 min com água e 10 min de eletrólito de corrida (tampão). No final do dia foi realizada uma limpeza do capilar com lavagem de hidróxido de sódio 1 mol. $\mathrm{L}^{-1}$ durante $5 \mathrm{~min}$, seguido de água durante $5 \mathrm{~min}$. 0 capilar foi armazenado em água durante a noite.

\subsection{OTIMIZAÇÃO DO MÉTODO (DESIGN) DOS EXPERIMENTOS E PROCESSAMENTO DE DADOS}

A escolha do eletrólito baseou-se na presença de um cromóforo com absorção na região do UV-VIS, permitindo a detecção indireta da taurina. Por outro lado, não absorve nas regiões da luz ultravioleta (210 e $274 \mathrm{~nm}$ ), possibilitando a detecção direta da cafeína. 
Em seguida, foi realizado um estudo univariado da faixa de pH. A faixa de 4,0 a 11,0 (intervalo 1,0) com base no pKa dos compostos foi estudada. Para tais estudos, usamos um capilar com bulbo estendido de 50 $\mu \mathrm{m}$ i.d. x $72 \mathrm{~cm}$ de comprimento total, um eletrólito contendo $10 \mathrm{mmol} . \mathrm{L}^{-1}$ de ácido benzóico e $50 \mathrm{mmol}$.L1 de SDS, sendo o pH ajustado de acordo com a matriz do projeto, utilizando NaOH (1 mol.L-1) e soluções de $\operatorname{HCl}\left(0,1\right.$ mol.L $\left.\mathrm{L}^{-1}\right)$. A injeção foi hidrodinâmica a 50 mbar por 5 se tensão de $+30 \mathrm{kV}$.

A partir dos resultados obtidos nos testes univariados, um delineamento composto central $2^{3}$, com pontos centrais e axiais, foi utilizado para investigar os efeitos individuais e de interação entre as variáveis de $\mathrm{pH}$, concentrações de eletrólito e SDS. 0 ponto central foi analisado em triplicata, totalizando 17 experimentos. Todos os experimentos foram conduzidos aleatoriamente. Os níveis empregados variaram de $10(-1,68)$ a $40 \mathrm{mmol} . \mathrm{L}^{-1}(+1,68)$ para a concentração do eletrólito; $10(-1,68)$ a $50 \mathrm{mmol} \cdot \mathrm{L}^{-1}(+1,68)$ para concentração de SDS; e entre 5,00 (-1,68) e 10,00 $(+1,68)$ para pH. A Tabela 1 mostra a matriz do delineamento composto central, com as variáveis codificadas e decodificadas.

Os experimentos foram realizados com a injeção de amostra adicionada de padrões, nas concentrações de 0,5 mg.mL $\mathrm{mL}^{-1}$ de cafeína e $5 \mathrm{mg} \cdot \mathrm{mL}^{-1}$ para taurina. Todas as condições do planejamento composto central foram injetadas a 50 mbar de pressão por $5 \mathrm{~s}$, temperatura de $25^{\circ} \mathrm{C}$ e detecção indireta a $230 \mathrm{~nm}$ para taurina e detecção direta a $274 \mathrm{~nm}$, para cafeína. Antes de cada condição do planejamento foi realizado um condicionamento do capilar por 5 minutos com hidróxido de sódio 1 mol. $\mathrm{L}^{-1}, 5$ minutos com água e 10 minutos do eletrólito da condição em estudo, a fim de manter as condições iniciais do capilar sempre a mesma. Cada condição experimental foi injetada em duplicata, sendo que entre as corridas da mesma condição o capilar foi condicionado por 2 minutos com o eletrólito.

Tabela 1. Variáveis, níveis e respostas do planejamento composto central realizado para a otimização na determinação de taurina e cafeína em bebidas energéticas.

\begin{tabular}{|c|c|c|c|c|c|c|c|c|c|c|c|}
\hline \multirow[b]{2}{*}{ ensaio } & \multicolumn{3}{|c|}{$\begin{array}{l}\text { Variáveis } \\
\text { codificadas }\end{array}$} & \multicolumn{3}{|c|}{ Variáveis decodificadas } & \multicolumn{5}{|c|}{ Respostas } \\
\hline & A & B & c & $\mathrm{ApH}$ & $\begin{array}{c}\text { B concentração } \\
\text { de eletrólito } \\
\left(\text { mmol.L }{ }^{-1}\right)\end{array}$ & $\begin{array}{c}\text { C } \\
\text { concentração } \\
\text { SDS }\left(\text { mmol.L }{ }^{-1} \text { ) }\right.\end{array}$ & $\begin{array}{c}\text { Diferença } \\
\text { tempo } \\
\text { FEO/cafeína } \\
\text { (min) }\end{array}$ & $\begin{array}{c}\text { Resolução } \\
\text { Taurina e } \\
\text { cafeina }\end{array}$ & $\begin{array}{c}\text { Simetria } \\
\text { taurina }\end{array}$ & $\begin{array}{l}\text { Altura pico } \\
\text { Taurina } \\
\text { (mUA) }\end{array}$ & $\begin{array}{c}\text { Variação linha } \\
\text { de base a } \\
230 \mathrm{~nm} \\
(\mathrm{mUA})\end{array}$ \\
\hline 1 & -1.00 & -1.00 & -1.00 & 6.00 & 16.10 & 16.10 & 0.25 & 13.3 & 9.2 & 453.3 & 181.6 \\
\hline 2 & -1.00 & -1.00 & 1.00 & 6.00 & 16.10 & 39.90 & 0.55 & 11.4 & 10.1 & 505.9 & 85.6 \\
\hline 3 & -1.00 & 1.00 & -1.00 & 6.00 & 33.90 & 16.10 & 0.07 & 27.5 & 7.6 & 296.2 & 156.2 \\
\hline 4 & -1.00 & 1.00 & 1.00 & 6.00 & 33.90 & 39.90 & 0.79 & 20.4 & 8.0 & 312.7 & 172.2 \\
\hline 5 & 1.00 & -1.00 & -1.00 & 9.00 & 16.10 & 16.10 & 0.20 & 12.1 & 10.3 & 514.2 & 24.0 \\
\hline 6 & 1.00 & -1.00 & 1.00 & 9.00 & 16.10 & 39.90 & 0.53 & 10.4 & 11.3 & 492.6 & 43.9 \\
\hline 7 & 1.00 & 1.00 & -1.00 & 9.00 & 33.90 & 16.10 & 0.11 & 25.3 & 7.4 & 307.5 & 138.6 \\
\hline 8 & 1.00 & 1.00 & 1.00 & 9.00 & 33.90 & 39.90 & 0.54 & 20.6 & 7.6 & 331.2 & 163.2 \\
\hline 9 & -1.68 & 0.00 & 0.00 & 5.00 & 25.00 & 25.00 & 1.83 & 8.4 & 10.1 & 612.3 & 1359.0 \\
\hline 10 & 1.68 & 0.00 & 0.00 & 10.00 & 25.00 & 25.00 & 0.23 & 16.3 & 9.8 & 477.6 & 212.9 \\
\hline 11 & 0.00 & -1.68 & 0.00 & 7.50 & 10.00 & 25.00 & 0.85 & 8.6 & 13.1 & 445.6 & 208.5 \\
\hline 12 & 0.00 & 1.68 & 0.00 & 7.50 & 40.00 & 25.00 & 0.35 & 28.2 & 6.9 & 195.5 & 114.1 \\
\hline 13 & 0.00 & 0.00 & -1.68 & 7.50 & 25.00 & 10.00 & 0.12 & 25.9 & 6.8 & 432.5 & 44.2 \\
\hline 14 & 0.00 & 0.00 & 1.68 & 7.50 & 25.00 & 50.00 & 1.01 & 15.3 & 10.1 & 401.0 & 242.1 \\
\hline 15 & 0.00 & 0.00 & 0.00 & 7.50 & 25.00 & 25.00 & 0.13 & 19.4 & 9.0 & 432.7 & 93.8 \\
\hline 16 & 0.00 & 0.00 & 0.00 & 7.50 & 25.00 & 25.00 & 0.21 & 18.4 & 9.4 & 460.4 & 168.5 \\
\hline 17 & 0.00 & 0.00 & 0.00 & 7.50 & 25.00 & 25.00 & 0.07 & 18.7 & 8.8 & 451.7 & 155.2 \\
\hline
\end{tabular}

SDS: dodecil sulfato de sódio; FEO: fluxo eletroosmótico.

Com base nos resultados obtidos nos ensaios, algumas respostas foram escolhidas para serem otimizadas, sendo elas: (1) a diferença de tempo entre o fluxo eletroosmótico e a cafeína, para avaliar a separação da cafeína do pico do sistema; (2) resolução entre a cafeína e taurina, calculada de acordo com a Equação 1; (3) simetria do pico da taurina, devido aos efeitos de dispersão resultantes da diferença de condutividade do eletrólito e da molécula de taurina, calculada conforme a Equação 2; (4) altura do pico da taurina, para a obtenção de menores limites de detecção; e (5) variação de linha de base a $230 \mathrm{~nm}$, muito significativa em detecções indiretas. Para cada resposta foram avaliados os modelos lineares e quadráticos quanto à 
falta de ajuste, distribuição de resíduos e significância das regressões através da Análise de Variância (ANOVA), ao nível de confiança de 95\%.

$$
R s=\frac{2\left(t_{2}-t_{1}\right)}{w_{2}+w_{1}} \quad \text { Equação } 1
$$

onde Rs representa o valor da resolução, t1 e t2 representam o tempo de migração de cada composto do par analisado e w1 e w2 representam a largura da base do pico de cada composto.

$$
\mathrm{S}=\frac{\mathrm{T}_{\text {final }}-\mathrm{T}}{\mathrm{T}-\mathrm{T}_{\text {inicial }}} \quad \text { Equação } 2
$$

onde $\mathrm{S}=$ simetria, $\mathrm{T}$ = tempo da altura máxima do pico, $\mathrm{Tfinal}=$ tempo do final da base do pico e Tinicial = tempo do inicio da base do pico.

Em seguida, para avaliar as respostas simultaneamente e determinar a melhor condição de análise, foi utilizada a função de desejabilidade de Derringer e Suich (1980), estipulando um valor de desejabilidade para cada resposta e, a partir disso, combina-os em um valor de desejabilidade global (BREITKREITZ, JARDIM \& BRUNS, 2009). 0 tratamento dos dados foi através do software Design Expert 6.0.4 (Minneapolis, EUA).

\subsection{VALIDAÇÃO DO MÉTODO POR ELETROFORESE CAPILAR}

O método foi validado de acordo com as recomendações do Guia para Validação de Métodos Analíticos e Bioanalíticos (BRASIL, 2017). Os limites de detecção e quantificação foram determinados através de diluições sucessivas das soluções padrões e estimados em 3 e 6 vezes a relação sinal/ruído, respectivamente. 0 limite de quantificação foi estabelecido com base no menor nível que apresentou coeficiente de variação relativo aceitável ( $\leq 20 \%)$ para a concentração avaliada. As curvas de calibração foram construídas em triplicatas aleatórias, cada uma com 07 níveis de concentração, de forma equidistante, considerando as concentrações esperadas nas amostras. A linearidade das curvas analíticas foi avaliada e o modelo linear foi validado através de análise de variância (ANOVA) para a falta de ajuste, distribuição de resíduos e significância da regressão.

Para avaliar a repetibilidade, foram realizadas 10 determinações em um único dia, incluindo 3 concentrações de curvas de calibração (correspondendo ao limite de quantificação-nível 1, o ponto intermediário da curva-nível 2 e a concentração máxima- nível 3). A precisão intermediária (entre dias) foi avaliada por meio de cinco determinações, nos mesmos níveis de concentração de repetibilidade, em cinco dias consecutivos. Para o estudo de exatidão, feito por recuperação, foi realizada a fortificação das amostras com padrões em concentrações conhecidas, também seguindo 3 níveis da curva (nas concentrações do limite de quantificação, do ponto intermediário e da concentração máxima) através de 3 determinações em cada nível. A robustez foi avaliada quanto ao pH do eletrólito, de forma univariada. Entre os dias de análise, o método foi monitorado por meio da análise de uma amostra comercial de referência a cada 4 horas.

\subsection{APLICAÇÃO EM AMOSTRAS}

As determinações nas amostras de bebidas energéticas foram realizadas segundo o método estabelecido para determinação de cafeína e taurina por cromatografia eletrocinética micelar, empregando um capilar de sílica fundida com bulbo estendido, com comprimento efetivo de $72 \mathrm{~cm}$ e $50 \mu \mathrm{m}$ de diâmetro interno, eletrólito constituído de ácido benzoico 16,2 mmol.L-1 com dodecil sulfato de sódio (SDS) 39,9 mmol.L-1, 
pH 7,26 ajustado com NaOH, injeção de 50 mbar por 5 s e voltagem de corrida de $(+30 \mathrm{kV})$. A detecção foi realizada nos comprimentos de onda de $230 \mathrm{~nm}$ e $274 \mathrm{~nm}$, para taurina e cafeína, respectivamente.

A identificação dos compostos foi realizada comparando-se os tempos de migração com os padrões e adição de padrões às amostras. Para a quantificação foram construídas curvas de calibração, com sete pontos em triplicata, na faixa de concentração de 4 a $85 \mathrm{mg} \cdot \mathrm{L}^{-1}$ para a cafeína e 15 a $237 \mathrm{mg} . \mathrm{L}^{-1}$ para a taurina. Para avaliar a diferença entre as marcas e lotes, o teor de cafeína e taurina das amostras foi submetido à análise de variância (ANOVA) e as médias comparadas estatisticamente pelo teste de Tukey usando o software Statistica 10 (Statsoft, USA). As amostras foram consideradas estatisticamente diferentes quando $\mathrm{p}<0,05$.

Para efeito de comparação entre os resultados obtidos nas amostras e as quantidades máximas estabelecidas pela legislação, foram calculados os intervalos de confiança (95\%) para cada lote, permitindo assim uma comparação estatisticamente confiável com a RDC 273/05 (BRASIL, 2005). Ainda segundo a RDC 273/05 para ingredientes adicionados às bebidas energéticas, como é o caso da cafeína e taurina, o teor desses ingredientes no produto e o valor declarado no rótulo deve obedecer aos limites máximos estabelecidos por esta legislação, sem limites de tolerância.

\section{RESULTADOS E DISCUSSÃO}

\subsection{OTIMIZAÇÃO DO MÉTODO E DESENHO EXPERIMENTAL}

Para o sistema de detecção direta da cafeína e indireta da taurina, o eletrólito de corrida escolhido foi o ácido benzoico, por apresentar em sua estrutura um cromóforo, que possui absortividade máxima a 230 nm e que não absorve a $274 \mathrm{~nm}$, região de absorção da cafeína. Desta forma a detecção simultânea dos compostos foi possível, sendo que a cafeína foi detectada de forma direta a $274 \mathrm{~nm}$ e a taurina de forma indireta a $230 \mathrm{~nm}$. Na Figura 1 estão apresentados os espectros de absorbância da cafeína e do ácido benzoico.

No estudo univariado do $\mathrm{pH}$, observou-se que valores acima de 10 aumentaram substancialmente o ruído da linha de base, e valores abaixo de 5 ampliaram notavelmente o tempo de análise. Já o estudo do surfactante SDS mostrou-se eficaz, sendo observado que quanto maior a concentração de SDS, maior o tempo de análise.

Figura 1 - Espectros de absorbância de soluções aquosas de cafeína e de ácido benzoico.

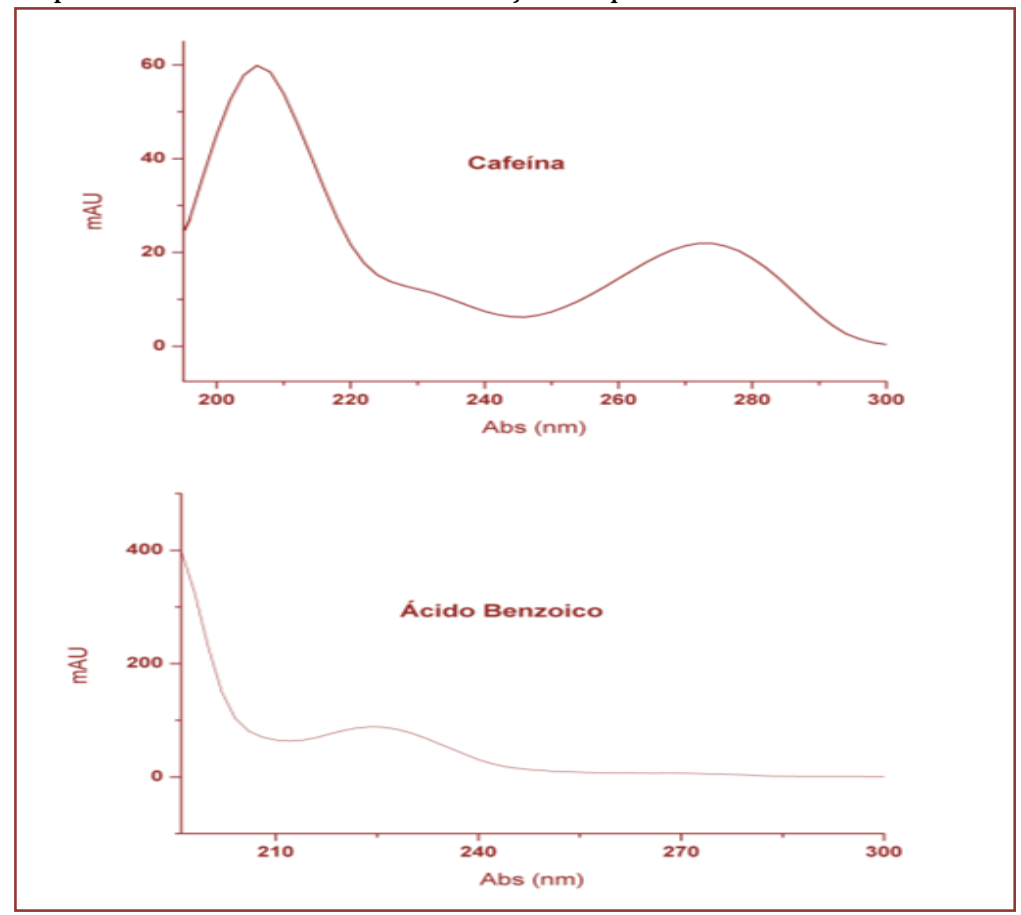

A Tabela 1 apresenta as respostas obtidas nos experimentos do delineamento composto central $2^{3}$. As cinco respostas investigadas (diferença de tempo entre o fluxo eletroosmótico e a cafeína, resolução entre 
a taurina e cafeína, variação na linha de base a $230 \mathrm{~nm}$, simetria do pico da taurina e altura do pico da taurina) foram avaliadas quanto aos modelos lineares e quadráticos através da Análise de Variância (ANOVA), ao nível de 95\% de confiança, sendo utilizado o modelo que apresentou melhor descrição das variáveis. Na Tabela 2 estão apresentados os testes para a falta de ajuste, significância da regressão e coeficientes dos modelos.

É possível verificar que os modelos para as respostas de simetria da taurina e altura do pico da taurina não apresentaram evidência de falta de ajuste. Por outro lado, os modelos de diferença do tempo entre o fluxo eletroosmótico e a cafeína, de resolução entre a taurina e cafeína e a variação na linha de base a 230 nm apresentaram falta de ajuste. Quanto a significância dos modelos, somente o parâmetro de variação na linha de base a $230 \mathrm{~nm}$, não apresentou modelo de regressão significativo, informação esta, pouco confiável já que ocorreu falta de ajuste e, do ponto de vista experimental, foram observadas muitas variações da linha de base entre as condições estudadas.

Tabela 2. Modelos matemáticos obtidos a partir das respostas do planejamento composto central, testes de falta de ajuste e da significância das regressões.

\begin{tabular}{|c|c|c|c|c|c|c|c|c|c|c|c|c|}
\hline \multirow[b]{2}{*}{ Respostas } & \multirow[b]{2}{*}{ Intercepto } & \multirow[b]{2}{*}{$\mathrm{ApH}$} & \multirow[b]{2}{*}{$\begin{array}{l}\text { B ácido } \\
\text { benzóico }\end{array}$} & \multicolumn{4}{|c|}{ Coeficientes de regressão (erros) } & \multirow[b]{2}{*}{$\mathrm{AB}$} & \multirow[b]{2}{*}{$\mathrm{AC}$} & \multirow[b]{2}{*}{$\mathrm{BC}$} & \multicolumn{2}{|c|}{$\begin{array}{c}\text { Testes de ajuste de } \\
\text { regressão }\end{array}$} \\
\hline & & & & $\operatorname{csDs}^{1}$ & $A^{2}$ & $\mathrm{~B}^{2}$ & $\mathrm{c}^{2}$ & & & & $\begin{array}{l}\text { F Cunculo }_{\text {falta de }} \\
\text { ajuste }\end{array}$ & 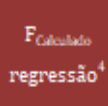 \\
\hline \begin{tabular}{|c|} 
Diferença tempo \\
$\mathrm{FEO}^{2} /$ cafeina
\end{tabular} & $0,46(0,09)$ & $-0,22(0,10)$ & $-0,06(0,10)$ & $0,24(0,10)$ & - & - & - & - & - & - & 32,87 & 3,47 \\
\hline $\begin{array}{c}\text { Resolução } \\
\text { taurina/cafeína }\end{array}$ & $18,78(1,29)$ & $0,66(0,60)$ & $5,82(0,60)$ & $-2,43(0,60)$ & $-2,16(0,67)$ & $-0,03(0,67)$ & $0,77(0,67)$ & $0,03(0,79)$ & $0,31(0,79)$ & $-1,04(0,79)$ & 22,76 & 14,17 \\
\hline Simetria taurina & $9,16(0,20)$ & $0,07(0,22)$ & $-1,52(0,22)$ & $0,60(0,22)$ & - & - & - & - & - & - & 7,95 & 18,77 \\
\hline $\begin{array}{c}\text { Altura pico } \\
\text { taurina }\end{array}$ & $449,88(25,02)$ & $-10,92(11,76)$ & $-83,44(11,76)$ & $1,33(11,76)$ & $28,81(12,95)$ & $-50,70(12,95)$ & $-16,62(12,95)$ & $-2,23(15,36)$ & $-8,37(15,36)$ & $1,15(15,36)$ & 12,8 & 8,92 \\
\hline $\begin{array}{c}\text { Variação linha } \\
\text { de base a } 230 \mathrm{~nm}\end{array}$ & $156,28(163,77)$ & $-157,68(76,95)$ & $10,00(76,95)$ & $21,75(76,95)$ & $171,84(84,78)$ & $-49,48(84,78)$ & $-55,91(84,78)$ & $21,59(100,50)$ & $15,56(100,50)$ & $14,59(100,50)$ & 70,91 & 1,24 \\
\hline
\end{tabular}

SDS1: dodecil sulfato de sódio; $\mathrm{FEO}^{2}$ : fluxo eletroosmótico; $\mathrm{F}_{\text {critico }}$ para o teste de falta de ajuste ${ }^{3}: 19,35$ (valores de $\mathrm{F}_{\text {calculado }}$ maiores que o $\mathrm{F}_{\text {crítico }}$ indicam modelo com falta de ajuste); $F_{\text {critico }}$ para a significância da regressão4: 3,55 (valores de $\mathrm{F}_{\text {calculado }}$ menores que o $\mathrm{F}_{\text {crítico }}$ indicam regressão significativa).

Tabela 3. Condições de desejabilidade empregadas na otimização simultânea das respostas, valores preditos pelos modelos e valores observados.

\begin{tabular}{|l|c|c|c|c|c|c|}
\multicolumn{1}{c}{ Variável/ Resposta } & \multicolumn{1}{c}{ Critério } & \multicolumn{7}{c}{ Limite inferior Limite superior Importância Valor previsto Valor observado } \\
\hline $\mathrm{pH}$ & Na faixa & $-1,00$ & 1,00 & 3 & 7,26 & - \\
\hline Concentração eletrólito & Na faixa & $-1,00$ & 1,68 & 3 & 16,20 & - \\
\hline Concentração SDS & Na faixa & $-1,68$ & 1,00 & 3 & 39,90 & - \\
\hline Diferença tempo FEO/cafeína & Na faixa & 0,80 & 2,00 & 5 & 0,80 & $0,31 \pm 0,02$ \\
\hline Resolução Taurina/Cafeina & Minimizar & 3,00 & 28,20 & 3 & 12,15 & $9,92 \pm 1,04$ \\
\hline Simetria taurina & Minimizar & 0,80 & 10,00 & 5 & 11,26 & $15,55 \pm 1,47$ \\
\hline Altura pico taurina & Maximiar & 300,0 & 613,00 & 5 & 469,83 & $517,15 \pm 15,63$ \\
\hline $\begin{array}{l}\text { Variação linha de base a 230 } \\
\text { nm }\end{array}$ & Minimizar & 1,0 & 1359,00 & 3 & 79,81 & $76,00 \pm 1,84$ \\
\hline
\end{tabular}

SDS: dodecil sulfato de sódio; FEO: fluxo eletroosmótico.

Quando um modelo usado para a otimização dos algoritmos apresenta falta de ajuste, a função de desejabilidade de Derringer e Suich (1980) pode não estimar corretamente a condição ótima. No entanto, é possível observar que a falta de ajuste para as respostas como (1)diferença do tempo entre o fluxo eletrosmótico e a cafeína; (2) resolução entre a taurina e a cafeína; e (3) a variação da linha de base a 230 $\mathrm{nm}$ para a taurina, foram consideradas pequenas, já que os valores de $\mathrm{F}$ calculados foram de 1,7, 1,2 e 3,7 vezes acima do valor do $\mathrm{F}_{\text {crítico, }}$ respectivamente. Alguns autores já demonstraram que o uso de modelos com pequena falta de ajuste podem ainda ser úteis para prever as condições analíticas. Dias et al. (2015), empregaram modelos com valores de $\mathrm{F}_{\text {calculado }}$ até 10 vezes superiores aos valores de Fcrítico obtendo 
resultados satisfatórios na otimização das respostas. Da mesma forma, em trabalhos realizados por Meinhart et al. (2011) e Ballus et al. (2014), modelos com ligeira falta de ajuste contribuíram significativamente para a otimização dos métodos de análise. Considerando que tais modelos apresentavam distribuição de resíduos aleatória, estes foram mantidos no processo de otimização simultânea das respostas.

Neste estudo, também foram conduzidas restrições de região experimental para reduzir o erro de previsão do algoritmo devido à falta de ajuste do modelo, como foi realizado por Dias et al. (2015). As respostas experimentais de diferença de tempo entre fluxo eletroosmótico e o tempo de migração da cafeína indicaram que as condições dos experimentos $3,5,7,10,13,15,16$ e 17 devem ser evitadas, uma vez que as respostas foram insatisfatórias (diferença menor que 0,25 min). A outra resposta com falta de ajuste (variação da linha de base) indica que as condições dos testes 9, 10, 11 e 14 apresentaram uma variação da linha de base muito elevada (acima de $200 \mathrm{mUA}$ ), devendo tais condições serem evitadas. A resposta para a resolução entre cafeína e taurina, apesar de apresentar falta de ajuste, não é preocupante, uma vez que todas as resoluções entre os compostos foram altas. Assim, foram estabelecidas restrições para rejeitar níveis de variáveis que eram experimentalmente prejudiciais para a diferença de tempo entre o fluxo eletroosmótico e a cafeína, e a variação da linha de base. Como pode ser observado na Tabela 3, o pH foi limitado aos níveis de -1,00 a 1,00; a concentração de ácido benzóico de -1,00 a 1,68; e a concentração de SDS de $-1,68$ a 1,00 .

Para o emprego do algoritmo de desejabilidade proposto por Derringer \& Suich (1980), uma desejabilidade individual foi estabelecida para cada variável a fim de obter a diferença de tempo entre o fluxo eletroosmótico e a cafeína acima de 0,8 e abaixo de 2,0 minutos, para obter a menor variação de linha de base possível, a maior altura do pico da taurina, e reduzir a simetria da taurina para valores próximos a 1,0, com mínimo aceitável de 0,8. Para a resolução entre cafeína e taurina, o critério de desejabilidade foi de reduzir (já que os valores eram muito altos, de 8 a 28), com o limite mínimo de 3,0, resolução considerada excelente para quantificação. Com a redução dos valores próximos a 3,0, há uma tendência de redução do tempo de análise.

A Tabela 3 também apresenta as condições de análise sugeridas para cada parâmetro, bem como as respostas experimentais previstas. As condições analíticas de $\mathrm{pH}$ 7,26, 16,20 mmol. $\mathrm{L}^{-1}$ de ácido benzóico e 39,90 mmol. $\mathrm{L}^{-1}$ de SDS foram testadas em triplicata, e os valores experimentais observados são apresentados na Tabela 3 com seus respectivos desvios.

Com exceção da resposta da diferença de tempo entre o fluxo eletroosmótico e a cafeína, outras respostas observadas foram muito próximas das respostas previstas. As diferenças podem ser atribuídas ao erro que existe em cada um dos modelos por falta de ajuste. No entanto, os modelos ainda foram úteis para a otimização do método analítico.

0 método foi validado e as figuras de mérito estão apresentadas na Tabela 4. Por meio da análise de variância, a regressão linear foi significativa nas faixas de concentração estudadas e o modelo matemático para a cafeína apresentou leve falta de ajuste (devido ao baixo erro experimental) e o modelo matemático para taurina não apresentou falta de ajuste $(\mathrm{p}>0,05)$, mostrando-se adequado para realizar quantificações. Os limites de quantificação foram adequados para a análise de bebidas energéticas com um método de extração extremamente simples. Os demais parâmetros também apresentaram resultados adequados para a quantificação de acordo com as exigências da ANVISA (BRASIL, 2003), demonstrando que o método é confiável para a determinação simultânea dos teores de cafeína e taurina em bebidas energéticas.

Na literatura, o teor de cafeína é geralmente determinado por HPLC, utilizando fases móveis contendo água e metanol ou acetonitrila (RAHIM ET AL., 2014) ou por eletroforese capilar (VOCHYÁNOVÁ ET AL., 2014), ambas com detecção de DAD. São métodos de análise simples e de curta duração (menos de 10 minutos). A análise do conteúdo de taurina, geralmente realizada por HPLC, requer detectores indiretos (CAO ET AL., 2003) ou deve ser precedida por reações de derivatização (MOU ET AL., 2002; ZINELLU ET AL., 2009) para detecção por DAD ou fluorescência. As reações de derivatização são caras e podem ser incompletas (MOU ET AL., 2002). 0 método desenvolvido e validado no presente estudo tem a vantagem de quantificar os dois compostos em uma única análise, utilizando apenas um detector, sem o uso de solventes orgânicos, com um curto tempo de análise e um preparo de amostra extremamente simples. 
Tabela 4. Figuras de mérito da validação do método de análise para cafeína e taurina em bebidas energéticas.

\begin{tabular}{|c|c|c|c|}
\hline \multirow{2}{*}{\multicolumn{2}{|c|}{ Parâmetros }} & \multicolumn{2}{|c|}{ Compostos } \\
\hline & & Cafeína & Taurina \\
\hline \multicolumn{2}{|l|}{ Faixa linear (mg. L-1) } & $4-84$ & $15-235$ \\
\hline \multicolumn{2}{|l|}{$\mathrm{F}$ (falta de ajuste)* } & 6,76 & 2,59 \\
\hline \multicolumn{2}{|c|}{ Limite de detecção (mg. $\left.\mathrm{L}^{-1}\right)$} & 2 & 7,5 \\
\hline \multicolumn{2}{|c|}{ Limite de quantificação (mg. $\mathrm{L}^{-1}$ ) } & 4 & 15 \\
\hline \multirow{3}{*}{$\begin{array}{l}\text { Repetitividade }(\mathrm{n}=10) \\
\mathrm{CV}\end{array}$} & Nível 1 & $15,93 \%$ & $13,80 \%$ \\
\hline & Nível 2 & $8,21 \%$ & $13,25 \%$ \\
\hline & Nível 3 & $8,75 \%$ & $10,57 \%$ \\
\hline \multirow{3}{*}{$\begin{array}{l}\text { Precisão intermediária } \\
(\mathrm{n}=5) \mathrm{CV}\end{array}$} & Nível 1 & $10,57 \%$ & $14,27 \%$ \\
\hline & Nível 2 & $5,59 \%$ & $13,12 \%$ \\
\hline & Nível 3 & $3,97 \%$ & $10,57 \%$ \\
\hline \multirow{3}{*}{ Recuperação (n=3) CV } & Nível 1 & $105,11 \%$ & $117,18 \%$ \\
\hline & Nível 2 & $111,26 \%$ & $120,81 \%$ \\
\hline & Nível 3 & $118,83 \%$ & $115,40 \%$ \\
\hline
\end{tabular}

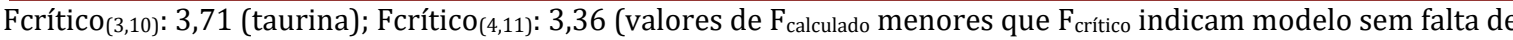
ajuste). Concentração para a repetitividade, precisão intermediária e recuperação: níveis 1, 2 e 3, equivalente a 4, 40 e $84 \mathrm{mg} . \mathrm{L}^{-1}$ para cafeína e 15,110 ,e $235 \mathrm{mg} . \mathrm{L}^{-1}$ para a taurina, respectivamente.

\subsection{DETERMINAÇÃO DO TEOR DE CAFEÍNA E TAURINA NA AMOSTRA DE BEBIDAS ENERGÉTICAS.}

A Figura 2 apresenta um eletroferograma obtido na determinação de cafeína e taurina em uma amostra de bebida energética e na Tabela 5 estão apresentadas as concentrações médias de cafeína e taurina presentes em cada lote das 22 marcas de bebida energética analisadas.

Figura 2 - Eletroferograma obtido na determinação de cafeína e taurina em uma amostra de bebida energética. Capilar de $50 \mu \mathrm{m}$ de d.i x $72 \mathrm{~cm}$ de comprimento efetivo com bulbo estendido, eletrólito ácido benzoico 16,2 mmol.L-1 com dodecil sulfato de sódio (SDS) 39,9 mmol.L-1 ${ }^{-1}$ pH 7,26, $30 \mathrm{kV}, 25{ }^{\circ} \mathrm{C}$, injeção de 50 mbar por $5 \mathrm{~s}$ e detecção a $274 \mathrm{~nm}$ (cafeína) e a $230 \mathrm{~nm}$ (taurina).

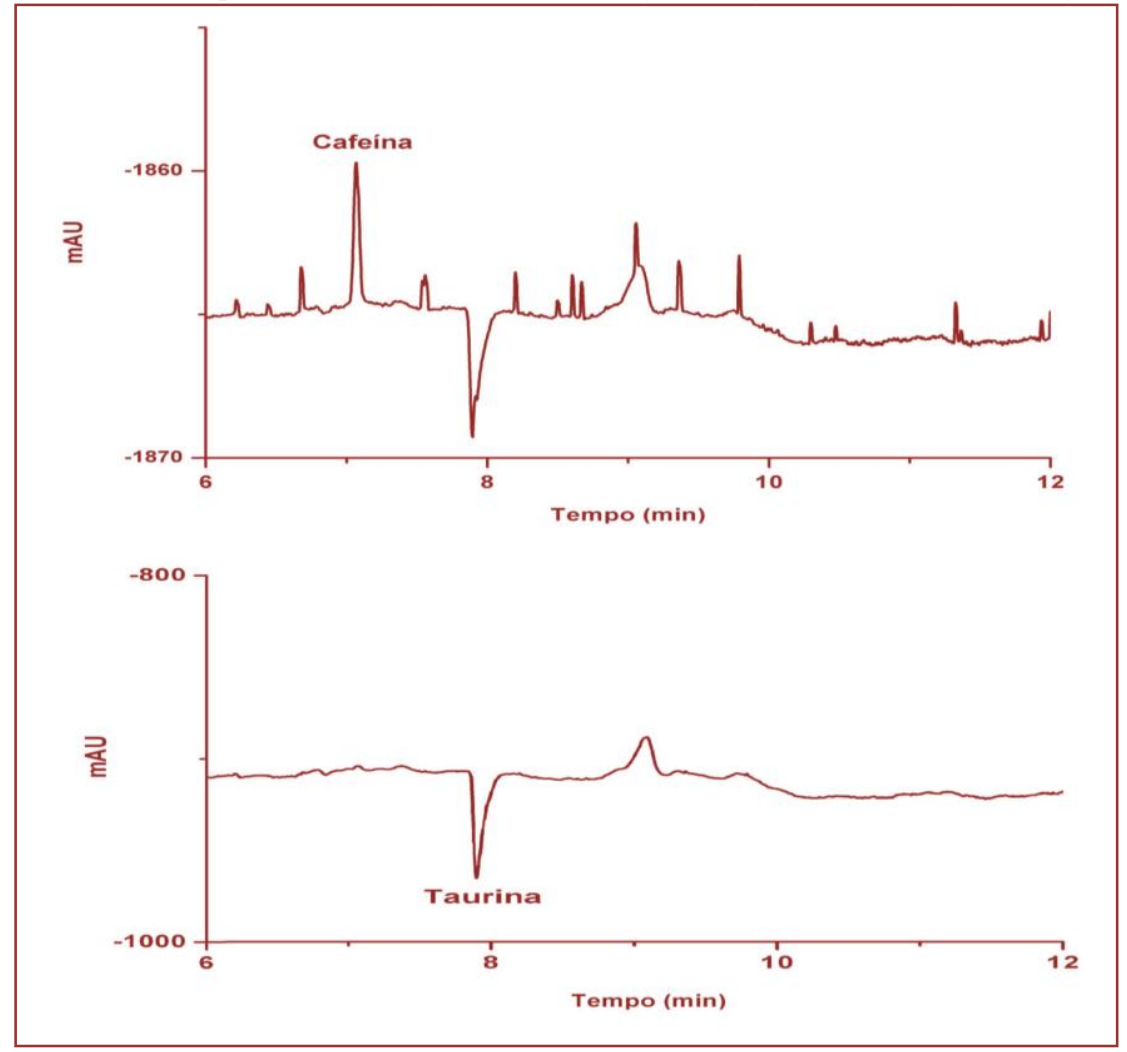


Tabela 5. Conteúdo médio de cafeína e taurina (mg.L-1) e o intervalo de confiança (95\%) das amostras de bebida energética analisadas.

\begin{tabular}{|c|c|c|c|c|c|c|c|}
\hline \multirow[b]{2}{*}{ marcas } & \multirow[b]{2}{*}{ lote } & \multicolumn{3}{|c|}{ Cafeína } & \multicolumn{3}{|c|}{ Taurina } \\
\hline & & $\begin{array}{l}\text { Concentração } \\
\text { (mg.100 mL-1) }\end{array}$ & IC (95\%) & VD & $\begin{array}{l}\text { Concentração } \\
\text { (mg.100 mL-1) }\end{array}$ & IC (95\%) & VD \\
\hline \multirow{3}{*}{1} & $\mathrm{~A}$ & $24,9 \pm 1,2^{\mathrm{a}}$ & $21,9-27,9$ & \multirow{3}{*}{32,0} & $614,2 \pm 5,7 \mathrm{a}$ & $525,4-703,0$ & \multirow{3}{*}{400,0} \\
\hline & $\mathrm{B}$ & $25,9 \pm 1,9 a$ & $21,0-30,8$ & & $397,0 \pm 9,9 b$ & $372,5-421,5$ & \\
\hline & $\mathrm{C}$ & $25,3 \pm 1,4^{\mathrm{a}}$ & $21,9-28,6$ & & $457,1 \pm 13,1^{\mathrm{b}}$ & $400,4-513,8$ & \\
\hline & média & $25,4 \pm 0,5$ & & & $489,4 \pm 112,2$ & & \\
\hline \multirow{4}{*}{2} & A & $25,1 \pm 0,8^{a}$ & $23,1-27,0$ & \multirow{3}{*}{31,9} & $353,9 \pm 10,4^{a}$ & $256,1-451,8$ & \multirow{3}{*}{400,0} \\
\hline & $\mathrm{B}$ & $25,6 \pm 1,6^{a}$ & $21,8-29,5$ & & $407,6 \pm 7,3^{a}$ & $389,4-425,7$ & \\
\hline & $\mathrm{C}$ & $26,1 \pm 1,5^{a}$ & $22,3-30,0$ & & $412,1 \pm 14,5^{\mathrm{a}}$ & $376,1-448,0$ & \\
\hline & média & $25,6 \pm 0,5$ & & & $391,2 \pm 32,3$ & & \\
\hline \multirow{3}{*}{3} & $\mathrm{~A}$ & $27,6 \pm 1,4^{\mathrm{a}}$ & $24,1-31,0$ & \multirow{3}{*}{32,0} & $361,0 \pm 10,8^{c}$ & $334,1-387,9$ & \multirow{3}{*}{400,0} \\
\hline & $\mathrm{B}$ & $21,4 \pm 1,6^{b}$ & $17,4-25,4$ & & $434,5 \pm 4,3^{b}$ & $423,8-445,1$ & \\
\hline & $\mathrm{C}$ & $28,1 \pm 0,2^{a}$ & $27,7-28,5$ & & $459,4 \pm 6,8^{a}$ & $442,7-476,2$ & \\
\hline & média & $25,7 \pm 3,7$ & & & $418,3 \pm 51,1$ & & \\
\hline \multirow{3}{*}{$4^{(1)}$} & $\mathrm{A}$ & $25,0 \pm 1,2^{\mathrm{a}}$ & $22,1-27,8$ & \multirow{3}{*}{29,7} & $405,0 \pm 26,7^{a}$ & $338,7-471,3$ & \multirow{3}{*}{371,7} \\
\hline & $\mathrm{B}$ & $27,1 \pm 2,4^{\mathrm{a}}$ & $21,1-33,0$ & & $447,7 \pm 10,9 \mathrm{a}$ & $420,5-474,9$ & \\
\hline & $\mathrm{C}$ & $23,5 \pm 0,2^{\mathrm{a}}$ & $23,1-23,9$ & & $454,8 \pm 29,8^{a}$ & $380,5-528,7$ & \\
\hline & média & $25,2 \pm 1,8$ & & & $435,8 \pm 26,9$ & & \\
\hline \multirow{3}{*}{$4(2)$} & $\mathrm{A}$ & $26,4 \pm 0,7 \mathrm{a}$ & $24,7-28,1$ & \multirow{3}{*}{29,7} & $355,1 \pm 23,7 \mathrm{~b}$ & $296,2-414,0$ & \multirow{3}{*}{371,7} \\
\hline & $\mathrm{B}$ & $27,4 \pm 1,3^{\mathrm{a}}$ & $24,1-30,7$ & & $421,4 \pm 26,0^{a}$ & $356,8-486,0$ & \\
\hline & $\mathrm{C}$ & $22,2 \pm 1,4^{b}$ & $18,7-25,7$ & & $402,0 \pm 8,3^{\mathrm{ab}}$ & $381,4-422,6$ & \\
\hline & média & $25,3 \pm 2,8$ & & & $392,8 \pm 34,1$ & & \\
\hline \multirow{3}{*}{$5(1)$} & $\mathrm{A}$ & $30,6 \pm 0,5^{a}$ & $29,4-31,8$ & \multirow{3}{*}{32,5} & $419,6 \pm 27,5^{\mathrm{ab}}$ & $351,3-487,9$ & \\
\hline & B & $28,8 \pm 2,6^{a b}$ & $22,4-35,2$ & & $467,7 \pm 34,5^{a}$ & $381,9-553,5$ & 400,0 \\
\hline & $\mathrm{C}$ & $25,6 \pm 1,2^{\mathrm{b}}$ & $22,5-28,6$ & & $357,5 \pm 14,7 \mathrm{~b}$ & $320,9-394,1$ & \\
\hline & média & $28,3 \pm 2,6$ & & & $414,9 \pm 55,2$ & & \\
\hline & $\mathrm{A}$ & $32,5 \pm 0,7 \mathrm{a}$ & $30,7-34,2$ & & $437,5 \pm 35,1^{a}$ & $350,3-524,7$ & \\
\hline $5(3)$ & $\mathrm{B}$ & $31,0 \pm 0,6^{\mathrm{a}}$ & $29,5-32,5$ & 32,5 & $452,4 \pm 28,5^{a}$ & $381,6-523,2$ & 400,0 \\
\hline & $\mathrm{C}$ & $25,8 \pm 1,3^{b}$ & $22,6-29,0$ & & $411,7 \pm 0,7 \mathrm{a}$ & $410,0-413,3$ & \\
\hline & média & $29,8 \pm 3,5$ & & & $433,8 \pm 20,6$ & & \\
\hline & $\mathrm{A}$ & $33,0 \pm 1,3^{a}$ & $29,9-36,2$ & & $414,0 \pm 9,6^{b}$ & $390,1-437,9$ & \\
\hline 6 & $\mathrm{~B}$ & $32,7 \pm 1,3^{a}$ & $29,5-35,9$ & 32,0 & $476,1 \pm 11,5^{a}$ & $447,5-504,6$ & 400,0 \\
\hline & $\mathrm{C}$ & $24,0 \pm 1,2^{b}$ & $20,9-27,0$ & & $434,3 \pm 8,5^{b}$ & $413,1-455,5$ & \\
\hline & média & $29,9 \pm 5,1$ & & & $441,4 \pm 31,6$ & & \\
\hline & $\mathrm{A}$ & $23,6 \pm 0,6^{b}$ & $22,0-25,1$ & 30,8 & $307,6 \pm 21,6^{b}$ & $254,0-361,2$ & 384,6 \\
\hline 7 & $\mathrm{~B}$ & $30,4 \pm 2,5^{\mathrm{a}}$ & $24,2-36,6$ & 32,0 & $440,0 \pm 23,7^{a}$ & $381,3-498,8$ & 400,0 \\
\hline & $\mathrm{C}$ & $19,7 \pm 1,0^{\mathrm{b}}$ & $17,1-22,2$ & 30,8 & $307,5 \pm 3,4^{b}$ & $299,1-315,9$ & 384,6 \\
\hline & média & $24,5 \pm 5,4$ & & & $351,7 \pm 76,5$ & & \\
\hline & $\mathrm{A}$ & $24,2 \pm 0,8^{a}$ & $22,1-26,3$ & & $285,6 \pm 15,7^{b}$ & $246,5-324,6$ & \\
\hline 8 & $\mathrm{~B}$ & $21,2 \pm 1,3^{\mathrm{ab}}$ & $17,9-24,6$ & 32,0 & $347,0 \pm 22,6^{\mathrm{ab}}$ & $290,9-403,10$ & 400,0 \\
\hline & $\mathrm{C}$ & $20,5 \pm 1,7 \mathrm{~b}$ & $16,2-24,8$ & & $382,0 \pm 39,4^{a}$ & $284,0-480,0$ & \\
\hline & média & $22,0 \pm 2,0$ & & & $338,2 \pm 48,8$ & & \\
\hline & $\mathrm{A}$ & $29,8 \pm 0,6^{a}$ & $28,2-31,3$ & 346 & $402,8 \pm 24,9 \mathrm{ab}$ & $341,0-464,5$ & \\
\hline 9 & $\mathrm{~B}$ & $26,9 \pm 0,3^{b}$ & $26,2-27,7$ & 34,0 & $373,3 \pm 12,2^{b}$ & $343,0-403,6$ & 400,0 \\
\hline & $\mathrm{C}$ & $24,8 \pm 1,0^{c}$ & $22,4-27,2$ & 35,0 & $443,9 \pm 22,6^{a}$ & $387,7-500,0$ & \\
\hline & média & $27,2 \pm 2,5$ & & & $406,6 \pm 35,5$ & & \\
\hline & $\mathrm{A}$ & $28,5 \pm 0,7 \mathrm{a}$ & $26,6-30,3$ & & $362,7 \pm 5,5^{c}$ & $349,2-376,3$ & \\
\hline 10 & $\mathrm{~B}$ & $22,0 \pm 1,6^{b}$ & $18,0-26,0$ & 34,8 & $333,2 \pm 5,4^{b}$ & $319,8-346,6$ & 400,0 \\
\hline & $\mathrm{C}$ & $27,0 \pm 0,2^{\mathrm{a}}$ & $26,4-27,5$ & & $453,1 \pm 8,8^{a}$ & $431,3-475,0$ & \\
\hline
\end{tabular}


(Continuação...)

Tabela 5. Conteúdo médio de cafeína e taurina (mg.L-1) e o intervalo de confiança (95\%) das amostras de bebida energética analisadas.

\begin{tabular}{|c|c|c|c|c|c|c|c|}
\hline \multirow[b]{2}{*}{ marcas } & \multirow[b]{2}{*}{ lote } & \multicolumn{3}{|c|}{ Cafeína } & \multicolumn{3}{|c|}{ Taurina } \\
\hline & & $\begin{array}{l}\text { Concentração } \\
\left(\mathrm{mg} .100 \mathrm{~mL}^{-1}\right)\end{array}$ & IC (95\%) & VD & $\begin{array}{l}\text { Concentração } \\
\left(\mathrm{mg} .100 \mathrm{~mL}^{-1}\right)\end{array}$ & IC (95\%) & VD \\
\hline & média & $25,8 \pm 3,4$ & & & $383,0 \pm 62,5$ & & \\
\hline \multirow{4}{*}{11} & $\mathrm{~A}$ & $29,7 \pm 1,0^{\text {a }}$ & $27,2-32,1$ & \multirow{3}{*}{32,0} & $404,3 \pm 31,2^{\mathrm{a}}$ & $326,8-481,8$ & \multirow{3}{*}{400,0} \\
\hline & $\mathrm{B}$ & $30,2 \pm 0,4^{\mathrm{a}}$ & $29,4-31,1$ & & $471,6 \pm 37,1^{\mathrm{a}}$ & $379,4-563,7$ & \\
\hline & $\mathrm{C}$ & $25,6 \pm 1,4 \mathrm{~b}$ & $22,2-29,1$ & & $461,6 \pm 25,0^{a}$ & $399,5-523,7$ & \\
\hline & média & $28,5 \pm 2,5$ & & & $445,8 \pm 36,3$ & & \\
\hline \multirow{3}{*}{$12^{(1)}$} & $\mathrm{A}$ & $28,6 \pm 3,4^{a}$ & $20,3-37,0$ & \multirow{2}{*}{32,0} & $395,0 \pm 9,6^{b}$ & $371,1-418,9$ & \multirow{3}{*}{400,0} \\
\hline & $\mathrm{B}$ & $25,9 \pm 1,6^{a}$ & $21,9-30,0$ & & $449,4 \pm 6,3^{a}$ & $433,7-465,2$ & \\
\hline & $\mathrm{C}$ & $26,6 \pm 1,4^{\mathrm{a}}$ & $23,2-30,0$ & 32,1 & $445,7 \pm 28,0^{a}$ & $376,2-515,1$ & \\
\hline & média & $27,1 \pm 1,4$ & & & $430,0 \pm 30,4$ & & \\
\hline \multirow{3}{*}{$12^{(2)}$} & $\mathrm{A}$ & $28,8 \pm 1,4^{\mathrm{a}}$ & $25,3-32,4$ & \multirow{3}{*}{32,0} & $381,5 \pm 22,9 b$ & $324,6-438,5$ & \multirow{3}{*}{400,0} \\
\hline & B & $25,8 \pm 2,3 \mathrm{ab}$ & $20,2-31,5$ & & $369,8 \pm 13,9 b$ & $335,3-404,3$ & \\
\hline & $\mathrm{C}$ & $24,4 \pm 0,3^{b}$ & $23,5-25,2$ & & $458,9 \pm 21,0^{a}$ & $406,8-511,0$ & \\
\hline & média & $26,3 \pm 2,3$ & & & $403,4 \pm 48,4$ & & \\
\hline \multirow{3}{*}{$12^{(3)}$} & A & $34,6 \pm 2,3^{a}$ & $28,8-40,4$ & \multirow{3}{*}{32,0} & $464,4 \pm 8,8^{a}$ & $442,6-486,2$ & \multirow{3}{*}{400,0} \\
\hline & $\mathrm{B}$ & $32,8 \pm 3,5^{\mathrm{a}}$ & $24,0-41,5$ & & $475,0 \pm 6,3^{a}$ & $459,4-490,7$ & \\
\hline & $\mathrm{C}$ & $25,1 \pm 1,5^{b}$ & $21,4-28,7$ & & $461,8 \pm 14,1^{\mathrm{a}}$ & $426,7-496,9$ & \\
\hline & média & $30,8 \pm 5,1$ & & & $467,1 \pm 7,0$ & & \\
\hline \multirow{4}{*}{13} & $\mathrm{~A}$ & $34,0 \pm 2,9 a$ & $26,9-41,1$ & \multirow{3}{*}{35,0} & $387,6 \pm 20,2^{a}$ & $337,3-437,8$ & \multirow{3}{*}{400,0} \\
\hline & $\mathrm{B}$ & $26,5 \pm 0,6^{b}$ & $25,0-28,1$ & & $371,8 \pm 3,9 a$ & $362,1-381,5$ & \\
\hline & $\mathrm{C}$ & $30,3 \pm 1,6^{\mathrm{ab}}$ & $26,3-34,3$ & & $418,3 \pm 33,3^{a}$ & $335,6-501,0$ & \\
\hline & média & $30,3 \pm 3,7$ & & & $392,5 \pm 23,6$ & & \\
\hline \multirow{3}{*}{14} & $\mathrm{~A}$ & $21,0 \pm 1,3^{b}$ & $17,7-24,3$ & \multirow{3}{*}{35,0} & $304,9 \pm 6,9 \mathrm{~b}$ & $287,8-321,9$ & \multirow{2}{*}{393,8} \\
\hline & $\mathrm{B}$ & $21,8 \pm 1,1^{b}$ & $19,0-24,6$ & & $365,8 \pm 28,0^{a}$ & $296,1-435,4$ & \\
\hline & $\mathrm{C}$ & $27,6 \pm 0,7 \mathrm{a}$ & $26,0-29,3$ & & $406,6 \pm 16,4^{a}$ & $365,8-447,3$ & 400,0 \\
\hline & média & $23,5 \pm 3,6$ & & & $359,1 \pm 51,2$ & & \\
\hline & $\mathrm{A}$ & $31,0 \pm 2,6^{a}$ & $24,6-37,4$ & & $358,8 \pm 21,5^{b}$ & $305,4-412,3$ & \\
\hline 15 & $\mathrm{~B}$ & $31,4 \pm 0,4^{\mathrm{a}}$ & $30,3-32,4$ & 31,8 & $461,0 \pm 12,8^{a}$ & $429,3-492,7$ & 400,0 \\
\hline & $\mathrm{C}$ & $25,5 \pm 1,2^{b}$ & $22,5-28,6$ & & $189,0 \pm 10,3^{c}$ & $163,4-214,6$ & \\
\hline & média & $29,3 \pm 3,3$ & & & $336,3 \pm 137,4$ & & \\
\hline & $\mathrm{A}$ & $19,8 \pm 1,6^{\mathrm{ab}}$ & $16,0-23,7$ & & $255,4 \pm 16,8^{b}$ & $213,7-297,1$ & \\
\hline 16 & $\mathrm{~B}$ & $21,2 \pm 0,5^{a}$ & $19,9-22,5$ & 32,0 & $333,1 \pm 14,5^{\mathrm{a}}$ & $297,0-369,2$ & 400,0 \\
\hline & $\mathrm{C}$ & $18,4 \pm 0,6^{b}$ & $17,0-19,9$ & & $350,6 \pm 23,4^{a}$ & $292,5-408,7$ & \\
\hline & média & $19,8 \pm 1,4$ & & & $313,0 \pm 50,7$ & & \\
\hline & $\mathrm{A}$ & $32,7 \pm 2,4^{a}$ & $26,7-38,7$ & & $380,2 \pm 14,3^{b}$ & $344,6-415,8$ & \\
\hline 17 & $\mathrm{~B}$ & $26,6 \pm 1,3^{b}$ & $23,5-29,7$ & 32,0 & $453,6 \pm 16,6^{a}$ & $412,3-494,8$ & 400,0 \\
\hline & $\mathrm{C}$ & $30,2 \pm 1,6^{\mathrm{ab}}$ & $26,2-34,3$ & & $470,0 \pm 18,0^{a}$ & $425,4-514,6$ & \\
\hline & média & $29,8 \pm 3,1$ & & & $434,6 \pm 47,8$ & & \\
\hline 18 & A & $24,8 \pm 0,7 \mathrm{~b}$ & $23,0-26,5$ & 300 & $384,8 \pm 34,3^{a}$ & $299,5-470,0$ & 3725 \\
\hline 18 & $\mathrm{~B}$ & $27,5 \pm 1,2^{\mathrm{a}}$ & $24,4-30,5$ & & $380,5 \pm 3,2^{\mathrm{a}}$ & $372,7-388,4$ & $3 / 2,5$ \\
\hline & média & $26,1 \pm 1,9$ & & & $382,6 \pm 3,0$ & & \\
\hline 19 & $\mathrm{~A}$ & $31,5 \pm 1,1^{\mathrm{a}}$ & $28,7-34,3$ & 350 & $375,2 \pm 33,8^{\mathrm{a}}$ & $291,2-459,2$ & 4000 \\
\hline 19 & $\mathrm{~B}$ & $30,9 \pm 1,0^{a}$ & $28,5-33,3$ & 35,0 & $384,2 \pm 15,7^{a}$ & $345,3-423,1$ & 400,0 \\
\hline & média & $31,2 \pm 0,4$ & & & $379,7 \pm 6,4$ & & \\
\hline 20 & $\mathrm{~A}$ & $31,6 \pm 0,8^{a}$ & $29,7-33,6$ & 320 & $338,8 \pm 14,2^{b}$ & $303,6-373,9$ & 4000 \\
\hline 20 & $\mathrm{~B}$ & $31,5 \pm 1,4^{\mathrm{a}}$ & $28,1-34,8$ & $3 Z, 0$ & $430,5 \pm 14,5^{a}$ & $394,4-466,7$ & 400,0 \\
\hline
\end{tabular}


(Continuação...)

Tabela 5. Conteúdo médio de cafeína e taurina (mg.L-15) e o intervalo de confiança (95\%) das amostras de bebida energética analisadas.

\begin{tabular}{|c|c|c|c|c|c|c|c|}
\hline \multirow[b]{2}{*}{ marcas } & \multirow[b]{2}{*}{ lote } & \multicolumn{3}{|c|}{ Cafeína } & \multicolumn{3}{|c|}{ Taurina } \\
\hline & & $\begin{array}{l}\text { Concentração } \\
\left(\mathrm{mg} .100 \mathrm{~mL}^{-1}\right)\end{array}$ & IC (95\%) & VD & $\begin{array}{l}\text { Concentração } \\
\left(\mathrm{mg} .100 \mathrm{~mL}^{-1}\right)\end{array}$ & IC (95\%) & VD \\
\hline & média & $31,5 \pm 0,1$ & & & $384,7 \pm 64,9$ & & \\
\hline \multirow{2}{*}{21} & $\mathrm{~A}$ & $32,3 \pm 0,5^{\mathrm{a}}$ & $31,1-33,5$ & \multirow{2}{*}{32,0} & $401,8 \pm 32,1^{a}$ & $322,0-481,5$ & \multirow{2}{*}{400,0} \\
\hline & B & $28,7 \pm 0,8^{b}$ & $26,9-30,6$ & & $438,9 \pm 2,4^{a}$ & $433,0-444,9$ & \\
\hline & média & $30,5 \pm 2,6$ & & & $420,4 \pm 26,3$ & & \\
\hline \multirow{2}{*}{22} & A & $32,3 \pm 0,8^{a}$ & $30,3-34,2$ & \multirow{2}{*}{32,0} & $400,6 \pm 23,2^{a}$ & $343,0-458,2$ & \multirow{2}{*}{400,0} \\
\hline & B & $16,7 \pm 0,7 b$ & $14,9-18,5$ & & $282,0 \pm 11,2^{b}$ & $254,3-309,0$ & \\
\hline & média & $24,5 \pm 11,0$ & & & $341,3 \pm 83,8$ & & \\
\hline
\end{tabular}

VD: Valor declarado no rótulo (mg. $100 \mathrm{~mL}^{-1}$ ); (1): sabor tradicional; (2): zero açúcar; (3): saborizada. IC (95\%): Intervalo de confiança de 95\%, (n=3, t2=4,303). Letras minúsculas iguais entre os lotes de uma mesma marca indicam que não há diferença significativa entre os lotes de acordo com o teste de Tukey (95\% de confiança).

Em relação ao teor de cafeína presente nas 22 marcas analisadas, este variou de 19,8 mg.100 mL $\mathrm{mL}^{-1}$ 31,5 mg.100 $\mathrm{mL}^{-1}$, sendo que a marca 16 apresentou o nível mais baixo, que também foi significativamente diferente $(\mathrm{p}<0,05)$ do teor encontrado nas marcas $12 \mathrm{c}, 13,19,20,21$. Estas, por sua vez, não foram estatisticamente diferentes entre si.

Quanto ao teor de taurina, observou-se que o valor variou de 313,0 mg.100 mL a 489,4 mg.100 mL $\mathrm{mL}^{-1}$. Todas as marcas foram estatisticamente iguais entre si $(\mathrm{p}<0,05)$, exceto a marca 1 em relação à marca 16.

Quando avaliada a diferença do teor de cafeína e taurina entre os lotes de uma mesma marca, verificou-se que para cafeína apenas 6 marcas apresentaram igualdade estatística entre os lotes e que 16 marcas tiveram pelo menos um lote diferente dos demais. Em relação ao teor de taurina, 9 marcas apresentaram igualdade estatística entre os lotes e 13 marcas tiveram diferentes teor de taurina em pelo menos um dos lotes.

Segundo a ANVISA, o valor declarado no rótulo das bebidas energéticas deve ser equivalente ao conteúdo presente na bebida, sem nenhuma tolerância (BRASIL, 2005). Comparando o teor de cafeína com o valor declarado no rótulo e com valores dos intervalos de confiança, constatou-se que dentre as 22 marcas analisadas, 21 marcas apresentaram pelo menos um lote com o teor cafeína abaixo do valor declarado, sendo que destas, 09 marcas tiveram todos os lotes com níveis inferiores aos declarados. Somente a marca 20 apresentou todos os lotes com as mesmas concentrações de cafeína declaradas no rótulo.

Em relação ao teor de taurina, 11 marcas apresentaram pelo menos um lote com valor inferior ao declarado no rótulo. Apenas 04 marcas apresentaram todos os lotes com as mesmas concentrações de taurina que as declaradas no rótulo.

Segundo a ANVISA (BRASIL, 2005), o teor de cafeína e taurina presentes nas amostras deve estar abaixo do limite legal, sem tolerância, sendo $35 \mathrm{mg} .100 \mathrm{~mL}^{-1}$ e $400 \mathrm{mg} .100 \mathrm{~mL}^{-1}$, respectivamente. A partir dos intervalos de confiança (95\%), foi possível observar que nenhuma marca apresentou o teor de cafeína acima do limite máximo permitido. Em relação ao teor de taurina, 50\% das marcas apresentaram pelo menos um lote acima do limite máximo permitido. Resultados semelhantes foram encontrados para a cafeína por McCusker et al. (2006) usando cromatografia gasosa com detector de nitrogênio-fósforo e por Ballus et al. (2012) utilizando a técnica de cromatografia eletrocinética micelar com sistema de detecção DAD (MEKC). Os resultados obtidos neste trabalho, também foram similares aos apresentados por VOCHYANOVA ET AL. (2014), utilizando a técnica de cromatografia eletrocinética micelar (MECK) com capilar curto e sistema de dupla detecção com os detectores de condutividade por contato e fotométrico, na determinação simultânea de cafeína e taurina em bebidas energéticas.

\section{CONCLUSÕES}

O método desenvolvido apresentou parâmetros de validação adequados para a determinação dos compostos em amostras energéticas, mostrando sua aplicabilidade na detecção de teores de cafeína e taurina por eletroforese capilar, com baixo custo dos reagentes, tempo de análise reduzido, geração mínima de resíduos, não exposição do analista a solventes tóxicos e preparação de amostra extremamente simples. 
Já na avaliação de diferentes amostras de energéticos, o teor de cafeína esteve sempre abaixo do limite máximo permitido; por outro lado, o teor de taurina em $50 \%$ das amostras ficou acima do limite máximo permitido pela legislação brasileira para bebidas energéticas. Das 73 amostras, 68\% apresentaram quantidade de cafeína estatisticamente inferior à declarada no rótulo do produto, enquanto para a taurina, apenas 19\% apresentou quantidade inferior à declarada no rótulo do produto, estando em desacordo com a legislação brasileira.

A maioria das marcas apresentou heterogeneidade nos teores de cafeína e taurina entre os lotes analisados de uma mesma marca. Essas diferenças entre lotes de uma mesma marca mostram a necessidade de um controle mais rígido na padronização dos ingredientes adicionados.

\section{AGRADECIMENTOS}

Os autores agradecem a Capes, Fapesp e CNPq pelo suporte financeiro.

\section{REFERÊNCIAS}

[1] ALZAWQARI, M., AL-BAADANI, H. H., ALHIDARY, I. B., AL-OWAIMER, A., ABUDABOS, A. (2016). Effect of taurine and bile acid supplementation and their interaction on performance, serum components, ileal viscosity and carcass characteristics of broiler chickens. South African Journal of Animal Science, 46(4), 448. http://dx.doi.org/10.4314/sajas.v46i4.13.

[2] ATTILA, S., CAKIR, B. (2011). Energy-drink consumption in college students and associated factors. Nutrition, v. 27, n. 3, p. 316-322. http://dx.doi.org/ 10.1016/j.nut.2010.02.008

[3] BALlUS, C. A., MEINHART, A. D., BIZZOTTO, C. S., TEIXEIRA, J. FO., GODOY, H. T. (2012). A fast and efficient method for the study of caffeine levels in energy drinks using micellar electrokinetic chromatography (MEKC). Food Science and Technology, 32(2), 401-404. http://dx.doi.org/10.1590/S0101-20612012005000042.

[4] BALluS, C. A., MEINHART, A. D., DE SOUZA CAMPOS, F. A. JR., BRUNS, R. E., GODOY, H. T. (2014). Doehlert design-desirability function multi-criteria optimal separation of 17 phenolic compounds from extra-virgin olive oil by capillary zone electrophoresis. Food Chemistry, 146, 558- 568. http://dx.doi.org/10.1016/j.foodchem.2013.09.102.

[5] BizzotTo, C. S., MEINHART, A. D., BALluS, C. A., GHISELli, G., \& GODOY, H. T. (2013). Comparison of capillary electrophoresis and high performance liquid chromatography methods for caffeine determination in decaffeinated coffee. Food Science and Technology, 33(1), 186-191. http://dx.doi.org/10.1590/S010120612013005000013.

[6] BRASIL, AGÊNCIA NACIONAL DE VIGILÂNCIA SANITÁRIA - ANVISA. (2003, June 2). Guia para validação de métodos analíticos e bioanalíticos (Resolução RE no 899, de 29 de maio de 2003). Diário Oficial da República Federativa do Brasil.

[7] BRASIL, AGÊNCIA NACIONAL DE VIGILÂNCIA SANITÁRIA - ANVISA. (2005, September 23). Aprova o regulamento técnico para misturas para o preparo de alimentos e alimentos prontos para o consumo (Resolução RDC no 273, de 22 de setembro de 2005). Diário Oficial da República Federativa do Brasil.

[8] BRASIL, AGÊNCIA NACIONAL DE VIGILÂNCIA SANITÁRIA - ANVISA. (2017, July 25). Dispõe sobre a validação de métodos analíticose dá outras providências (Resolução RDC no 166, de 24 de julho de 2017). Diário Oficial da República Federativa do Brasil.

[9] BREITKREITZ, M.C., JARDIM, I. C. S. F., BRUNS, R. E. (2009). Combined column mobile phase mixture statical design optimization of high-performance liquid chromatographic analysis of multicomponent systems. Journal of Chromotography A, 216, 1439-1449. tp://dx.doi.org/10.1016/j.chroma.2008.12.093.

[10] .BUXTON, C., HAGAN, J. E. (2012). A survey of energy drinks consumption practices among student-athletes in Ghana: lessons for developing health education intervention programmes. Journal of the International Society of Sports Nutrition, 9(1), 9-15. http://dx.doi.org/ 10.1186/1550-2783-9-9

[11] CAO, Y., ZHANG, X., CHU, Q., FANG, Y., YE, J. (2003). Determination of taurine in Lycium Barbarum L. and other foods by capillary electrophoresis with electrochemical detection. Electroanalysis, 15(10), 898902. http://dx.doi.org/10.1002/elan.200390112.

[12] CARVAlHO, J. M., MAIA, G. A., SOUSA, P. H. M., RODRIGUES, S. (2006). Perfil dos principais componentes em bebidas energéticas: cafeína, taurina, guaraná e glucoronolactona. Revista Instituto Adolfo Lutz, 65(2), 78-85.

[13] CATHARINO, R. R., HADDAD, R., GODOY, H. T., EBERLIN, M. N., SANTOS, L. S. (2011). Fast analysis of taurine in energetic drinks by electrospray ionization mass spectrometry. Journal of the Brazilian Chemical Society, 22(4), 801806. http://dx.doi.org/10.1590/S0103-50532011000400026. 
[14] CHIRITA TAMPU, R. I., FINARU, A., \& ELFAKIR, C. (2018). Optimization of a HPLC analysis method for taurine and caffeine in energy drinks. Scientific Study \& Research: Chemistry \& Chemical Engineering, Biotechnology, Food Industry, 19(1), 23-32.

[15] DALl'AGnOL, T. M. (2006). Efeitos Fisiológicos Agudos da Associação de Taurina e Cafeína Contida em uma Bebida Energética em Indivíduos Fisicamente Ativos. Brasília: Universidade Católica de Brasília, 2006. Dissertação (Mestrado em Educação Física), Universidade Católica de Brasília, 2006.

[16] DERRINGER, G., SUICH, R. (1980). Simultaneous optimization of several response variables. Journal of Quality Technology, 12(4), 214- 219. http://dx.doi.org/10.1080/00224065.1980.11980968.

[17] DIAS, C. B., MEINHART, A. D., PANE, D. Q., BALLUS, C. A., GODOY, H. T. (2015). multivariate optimisation and validation of a method for the separation of five artificial sweeteners by UPLC-DAD in nine food matrices. Food Analytical Methods, 8(7), 1824-1835. http://dx.doi.org/10.1007/s12161-014-0056-8.

[18] GILES, G. E., MAHONEY, C. R., BRUNYÉ, T. T., GARDONY, A. L., TAYLOR, H. A., KANAREK, R. B. (2012). Differential cognitive effects of energy drink ingredients: caffeine, taurine, and glucose. Pharmacology, Biochemistry, and Behavior, 102(4), 569-577. http://dx.doi.org/10.1016/j.pbb.2012.07.004. PMid:22819803.

[19] GORON, A., MOINARD, C. (2018). Amino acids and sport: a true love story? Amino Acids, 50(8), 969980. http://dx.doi.org/10.1007/s00726-018-2591-x. PMid:29855718.

[20] HECKMAN, M. A., SHERRY, K., MEJIA, E. G. D. (2010). Energy drinks: an assessment of their market size, consumer demographics, ingredient profile, functionality, and regulations in the United States. Comprehensive Reviews in Food Science and Food Safety, 9(3), 303-317. http://dx.doi.org/10.1111/j.1541-4337.2010.00111.x.

[21] HEIDARI, R., JAMSHIDZADEH, A., NIKNAHAD, H., MARDANI, E., OMMATI, M. M., AZARPIRA, N., KHODAEI, F., ZAREI, A., AYARZADEH, M., MOUSAVI, S., ABDOLI, N., YEGANEH, B. S., SAEEDI, A., NAJIBI, A. (2016). Effect of taurine on chronic and acute liver injury: focus on blood and brain ammonia. Toxicology Reports, 3, 870879. http://dx.doi.org/10.1016/j.toxrep.2016.04.002.

[22] JAKOPIN, Ž. (2019). Risks associated with fat burners: a toxicological perspective. Food and Chemical Toxicology, 123, 205-224. http://dx.doi.org/10.1016/j.fct.2018.10.051.

[23] MALINAUSKAS, B. M.; AEBY, V. G.; OVERTON, R. F.; CARPENTER-AEBY, T.; BARBER-HEIDAL, K. (2007). A survey of energy drink consumption patterns among college students. Nutrition Journal, 6, 1-7.

[24] MCCUSKER, R. R., GOLDBERGER, B. A., CONE, E. J. (2006). Caffeine content of energy drinks, carbonated sodas, and other beverages. Journal of Analytical Toxicology, 30(2), 112-114. http://dx.doi.org/10.1093/jat/30.2.112.

[25] MCLELLAN, T. M., CALDWELL, J. A., LIEBERMAN, H. R. (2016). A review of caffeine's effects on cognitive, physical and occupational performance. Neuroscience and Biobehavioral Reviews, 71, 294312. http://dx.doi.org/10.1016/j.neubiorev.2016.09.001.

[26] MEINHART, A. D., BALluS, C. A., BRUNS, R. E., PALlONE, J. A. L., GODOY, H. T. (2011). Chemometrics optimization of carbohydrate separations in six food matrices by micellar electrokinetic chromatography with anionic surfactant. Talanta, 85(1), 237-244. http://dx.doi.org/10.1016/j.talanta.2011.03.056.

[27] MElE, A., MANTUANO, P., DE BELliS, M., RANA, F., SANARICA, F., CONTE, E., MORGESE, M. G., BOVE, M., ROLLAND, J. F., CAPOGROSSO, R. F., PIERNO, S., CAMERINO, G. M., TRABACE, L., DE LUCA, A. (2019). A long-term treatment with taurine prevents cardiac dysfunction in $\mathrm{mdx}$ mice. Translational Research, 204, 8299. http://dx.doi.org/10.1016/j.trsl.2018.09.004. PMid:30347179.

[28] MOU, S., DING, X., \& LIU, Y. (2002). Separation methods for taurine analysis in biological samples. Journal of Chromatography. B, Analytical Technologies in the Biomedical and Life Sciences, 781(1-2), 251267. http://dx.doi.org/10.1016/S1570-0232(02)00619-0. PMid:12450662.

[29] PANSANI, M. C., AZEVEDO, P. S., RAFACHO, B. P. M., MINICUCCI, M. F., CHIUSO-MINICUCCI, F., ZORZELLAPEZAVENTO, S. G., MARCHINI, J. S., PADOVAN, G. J., FERNANDES, A. A., MATSUBARA, B. B., MATSUBARA, L. S., ZORNOFF, L. A., PAIVA, S. A. (2012). Atrophic cardiac remodeling induced by taurine deficiency in wistar rats. PLoS One, 7(7), e41439. http://dx.doi.org/10.1371/journal.pone.0041439.

[30] PAULA LIMA, J., FARAH, A. (2019). Methylxanthines in stimulant foods and beverages commonly consumed in Brazil. Journal of Food Composition and Analysis, 78, 75-85. http://dx.doi.org/10.1016/j.jfca.2019.02.001.

[31] PEREIRA, J. C., SILVA, R. G., FERNANDES, A. A., MARINS, J. C. B. (2012). Efeito da ingestão de taurina no desempenho físico: uma revisão sistemática. Revista Andaluza de Medicina del Deporte, 5(4), 156162. http://dx.doi.org/10.1016/S1888-7546(12)70024-2.

[32] QU, F.; QI, Z.; LIU, K.; MOU, S. Ion chromatographic determination of taurine in medicine, nutrient capsule and human urine with electrochemical detection. Journal of Chromatography B, v. 730, p. 161-166, 1999. 
[33] RAHIM, A. A., NOFRIZAL, S., SAAD, B. (2014). Rapid tea catechins and caffeine determination by HPLC using microwave-assisted extraction and silica monolithic column. Food Chemistry, 147, 262268. http://dx.doi.org/10.1016/j.foodchem.2013.09.131.

[34] RAI, K. P., RAI, H. B., DAHAL, S., CHAUDHARY, S., SHRESTHA, S. (2016). Determination of caffeine and taurine contents in energy drinks by HPLC-UV.Journal of Food Science and Technology Nepal, 9, 6673. http://dx.doi.org/10.3126/jfstn.v9i0.16199.

[35] REID, J. L., MCCRORY, C., WHITE, C. M., MARTINEAU, C., VANDERKOOY, P., FENTON, N., HAMMOND, D. (2016). Consumption of caffeinated energy drinks among youth and young adults in Canada. Preventive Medicine Reports, 5, 65-70. http://dx.doi.org/10.1016/j.pmedr.2016.11.012.

[36] SANCTIS, V., SOLIMAN, N., SOlimAN, A. T., ELSEDFY, H., DI MAIO, S., EL KHOLY, M., FISCINA, B. (2017). Caffeinated energy drink consumption among adolescents and potential health consequences associated with their use: a significant public health hazard. Acta Biomedica, 88(2), 222-231. http://dx.doi.org/10.23750/abm.v88i2.6664.

[37] SAWABE, Y., TAGAMI, T., YAMASAKI, K. (2008). Determination of taurine in energy drinks by HPLC using a pre-column derivative. Journal of Health Science, 54(6), 661-664. http://dx.doi.org/10.1248/jhs.54.661.

[38] SEIFERT, S. M., SCHAECHTER, J. L., HERSHORIN, E. R., LIPSHULTZ, S. E. (2011). Health effects of energy drinks on children, adolescents, and young adults. Pediatrics, 127(3), 511-528. http://dx.doi.org/10.1542/peds.20093592 .

[39] TEMPLE, J. L. (2019). Review: trends, safety, and recommendations for caffeine use in children and adolescents. Journal of the American Academy of Child and Adolescent Psychiatry, 58(1), 3645. http://dx.doi.org/10.1016/j.jaac.2018.06.030.

[40] TRABUlO, D., MARQUES, S., PEDROSO, E. (211). Caffeinated energy drink intoxication. Journal Medical Emergency, 28, 712-714. http://dx.doi.org/10.1136/emj.09.2010.3322rep.

[41] TRAN, N. L., BARRAJ, L. M., BI, X., JACK, M. M. (2016). Trends and patterns of caffeine consumption among US teenagers and young adults, NHANES 2003-2012. Food and Chemical Toxicology, 94, 227242. http://dx.doi.org/10.1016/j.fct.2016.06.007.

[42] TSITSIMPIKOU, C., CHRISOSTOMOU, N., PAPALEXIS, P., TSAROUHAS, K., TSATSAKIS, A., JAMURTAS, A. (2011). The use of nutritional supplements among recreational athletes in Athens, Greece. International Journal of Sport Nutrition and Exercise Metabolism, 21(5), 377-384. http://dx.doi.org/10.1123/ijsnem.21.5.377

[43] TURAK, F., GÜZEL, R., DINÇ, E. (2017). Simultaneous determination of ascorbic acid and caffeine in commercial soft drinks using reversed-phase ultraperformance liquid chromatography. Journal of Food and Drug Analysis, 25(2), 285-292. http://dx.doi.org/10.1016/j.jfda.2016.09.004. PMid:28911669.

[44] VOCHYÁNOVÁ, B., OPEKAR, F., TŮMA, P. (2014). Simultaneous and rapid determination of caffeine and taurine in energy drinks by MEKC in a short capillary with dual contactless conductivity/photometry detection. Electrophoresis, 35(11), 1660-1665. http://dx.doi.org/10.1002/elps.201300480.

[45] WELCH, C. J., REGALADO, E. L., KRAML, C., WELCH, E. C., WELCH, M. J., SEMMELHACK, H., ALMSTEAD, D., KRESS, A. S., HIDALGO, N. A., KRESS, M. H. (2015). MISER LC-MS analysis of teas, soft drinks and energy drinks. LCGC North America, 33(4), 262-269.

[46] WEN, C., LI, F., ZHANG, L., DUAN, Y., GUO, Q., WANG, W., HE, S., LI, J., YIN, Y. (2019). Taurine is involved in energy metabolism in muscles, adipose tissue, and the liver. Molecular Nutrition \& Food Research, 63(2), e1800536. http://dx.doi.org/10.1002/mnfr.201800536. PMid:30251429.

[47] ZINELlU, A., SOTGIA, S., SCANU, B., CHESSA, R., GASPA, L., FRANCONI, F., DEIANA, L., CARRU, C. (2009). Taurine determination by capillary electrophoresis with laser-induced fluorescence detection: from clinical field to quality food applications. Amino Acids, 36(1), 35-41. http://dx.doi.org/10.1007/s00726-007-0022-5. 


\section{Capítulo 12}

Caracterização físico-química e rendimento na obtenção da carne mecanicamente separada do peixe tibiro (Oligoplites palometa)

\section{Franky Soedirlan Resosemito}

Jaqueline da Silva Rumão

Cleidiana Furtado Teixeira Belfort

Hemily Eduarda Santos Lopes

Andressa Ellen Castro Sousa

Douglas Sodre Ferreira

Resumo: 0 peixe Tibiro (Oligoplites palometa) é considerado fauna acompanhante, de menor valor comercial e alto teor nutritivo, verdadeiros aliados na tentativa de sanar os problemas nutricionais no estado de Maranhão. A carne mecanicamente separada (CMS) deste peixe foi feita através de processo de separação mecanizada da parte comestível, gerando partículas de músculo esquelético isentas de vísceras, ossos e pele com a vantagem de uma melhor flexibilidade de processamento, conforme o tipo de produto desejado e proporciona maior rendimento de carne comestível do que por filetagem. 0 objetivo deste trabalho é a caracterização físico-química da CMS do peixe Tibiro com três tipos de tratamentos (A - CMS sem lavar, B - CMS com uma lavagem e C - CMS com duas lavagens). 0 experimento foi conduzido no Laboratório de Pescado do setor Agroindústria do IFMA São Luis - Campus Maracanã. Diante disso, observou-se que quanto mais lavagens sofrer a CMS, maiores serão as perdas das proteínas, assim, ocasionando um produto final sem tantas qualidades nutricionais. 0 processamento do peixe Tibiro na forma de CMS pode ser uma alternativa para aproveitamento de uma espécie sub-utilizada, gerando possibilidades de oferta de uma fonte protéica com valor agregado de custo relativamente baixo.

Palavras-Chave: Carne Mecanicamente Separada (CMS); Peixe Tibiro; rendimento e analise físico-química. 


\section{INTRODUÇÃO}

0 peixe tibiro (Oligoplites palometa) que é descarregado na Raposa (MA) e apreciado pela comunidade local, não chegou ao comércio ludovicense apesar de ser bastante consumido no sul do país. A espécie é considerada fauna acompanhante, ou seja, é recolhida quando se pesca outros peixes, e vendida a cerca de dois reais o quilo.

0 peixe tibiro apresentou $0,76 \%$ de lipídios numa amostra de $100 \mathrm{~g}$, enquanto pescada, cação e pargo apresentaram $11,37 \%, 4,6 \%$ e 0,58\%, respectivamente, sendo uma espécie com pouca gordura. Para cada $100 \mathrm{~g}$ de tibiro, têm-se $107,7 \mathrm{kcal}$. 0 tibiro é o peixe com os maiores teores dos três macrominerais estudados, chegando a quase um grama de sódio e potássio por amostra. Seu teor de magnésio chega a ser maior que os teores dos três outros peixes somados. Ele tem ainda a maior quantidade de ferro e zinco. Tais percentuais significam que a ingestão de $100 \mathrm{~g}$ de tibiro assegura $22,4 \%$ das necessidades de proteínas, $1,3 \%$ das de lipídios, 59,3\% de magnésio, 56\% de sódio, 16,5\% de potássio, 109,7\% de ferro, $27,1 \%$ das de zinco e $6,6 \%$ das necessidades de cobre. Considerando a renda per capita do maranhense, que segundo o PNAD de 2007 é de até meio salário mínimo, uma das mais baixas do país, o consumo regular de tibiro compromete apenas $0,4 \%$ dos gastos mensais por pessoa. Em relação às proteínas, o tibiro apresentou quantidade satisfatória, com $25 \%$, o segundo maior percentual, enquanto a pescada apresentou a menor taxa, com $17,1 \%$.

A Carne Mecanicamente Separada (CMS) de pescado são de fácil digestão e fonte de proteínas, minerais, principalmente cálcio e fósforo, vitaminas $\mathrm{A}$, D e complexo $\mathrm{B}$, o que o torna um produto de alto valor nutricional (BORDIGNON et al., 2010; FELTES et al., 2010). A CMS do peixe tibiro (Oligoplites palometa) é feito através de processo de separação mecanizada da parte comestível, gerando partículas de músculo esquelético isentas de vísceras, ossos e pele. A CMS é produzida por tecnologia própria e não deve ser confundido simplesmente com pescado triturado. A CMS é um produto intermediário que serve como matéria-prima na obtenção do surimi, hambúrguer, produtos embutidos, empanados, etc. A utilização de um efetivo processamento, gerando novos produtos, poderia aumentar consideravelmente seu valor comercial (HOSDA et al., 2013; MINOZZO, 2010).

0 processo de lavagem pode melhorar a qualidade e as características funcionais da CMS de peixe tibiro, removendo sangue, pigmentos, proteínas sarcoplasmáticas, componentes solúveis, lipídios e outras substâncias que podem estimular a degradação proteica, a oxidação lipídica responsável pela coloração indesejável no produto final. Entretanto, a lavagem conduz à perda de proteína e outros nutrientes solúveis, gerando efuente líquido abundante. Simões et al. (1998) observaram diminuições nos teores de proteína, lipídios e cinzas de aproximadamente 53, 62 e 89\%, respectivamente, durante o processo de lavagem de CMS de pescada olhuda. Sary et al. (2009) relataram perdas de sólidos de aproximadamente $37 \%$ durante a lavagem de CMS de rockfish (Sebastes. sp.), com diminuição dos teores de P, Mg, K e Na nas CMS lavadas. Segundo Kirschnik e Macedo-Viegas (2009), o processo de lavagem remove os próoxidantes e antioxidantes solúveis em água, tornando a CMS mais susceptível à oxidação. Entretanto, segundo os autores, o processo de lavagem também remove, significativamente, os produtos gerados pela oxidação lipídica durante a extração da CMS. Durães (2009), Sary et al. (2009) e Vidal (2007) observaram que, independente da lavagem da CMS de tilápia, estas permaneceram estáveis e próprias para o consumo durante 180 dias de armazenamento a $-16{ }^{\circ} \mathrm{C}$. Este trabalho servirá como base para futuros desenvolvimentos, pois a partir dos resultados obtidos, serão possível aumentar e valorizar o consumo da CMS do peixe tibiro por meio da diversificação na linha de processamento, através da elaboração de novos produtos e subprodutos, que oferecem ao consumidor maiores opções de escolha.

\section{MATERIAL E MÉTODOS}

Foram utilizadas aproximadamente 20 peixes Tibiro (Oligoplites palometa), com peso médio de $136 \mathrm{~g}$ $( \pm 23 \mathrm{~g})$, provenientes da região de São José de Ribamar (Maranhão, Brasil). Os peixes foram colocadas em caixas térmicas com gelo e levadas ao Laboratório de Processamento de pescado do IFMA São Luis Campus Maracanã. No laboratório, os peixes foram lavados com água clorada (5ppm), descabeçados, eviscerados (de acordo com a figura 1) e lavados novamente. Logo após a limpeza, a CMS do peixe tibiro foi extraída. Após este processo inicial a CMS obtida foi dividida em dois tratamentos:

Tratamento A $\rightarrow$ CMS NÃO LAVADA.

Tratamento B $\rightarrow$ CMS LAVADA. a CMS obtida foi lavada com água gelada na proporção de 3L de água para $1 \mathrm{~kg}$ de CMS. Agitou-se por 2 minutos e deixou-se em repouso por 3 minutos. Logo após, a mistura foi filtrada através de um tecido de nylon para retirada do excesso de água. 
Tratamento $\mathrm{C} \rightarrow$ CMS LAVADA MAIS UMA VEZ. Após o tratamento B, a CMS do peixe tibiro é novamente lavada com água gelada na proporção de $3 \mathrm{~L}$ de água para $1 \mathrm{~kg}$ de CMS. Agitou-se por 2 minutos e deixou-se em repouso por 3 minutos. Logo após, a mistura foi filtrada através de um tecido de nylon para retirada do excesso de água. As analises fisico-quimicos foram realizadas em triplicata.

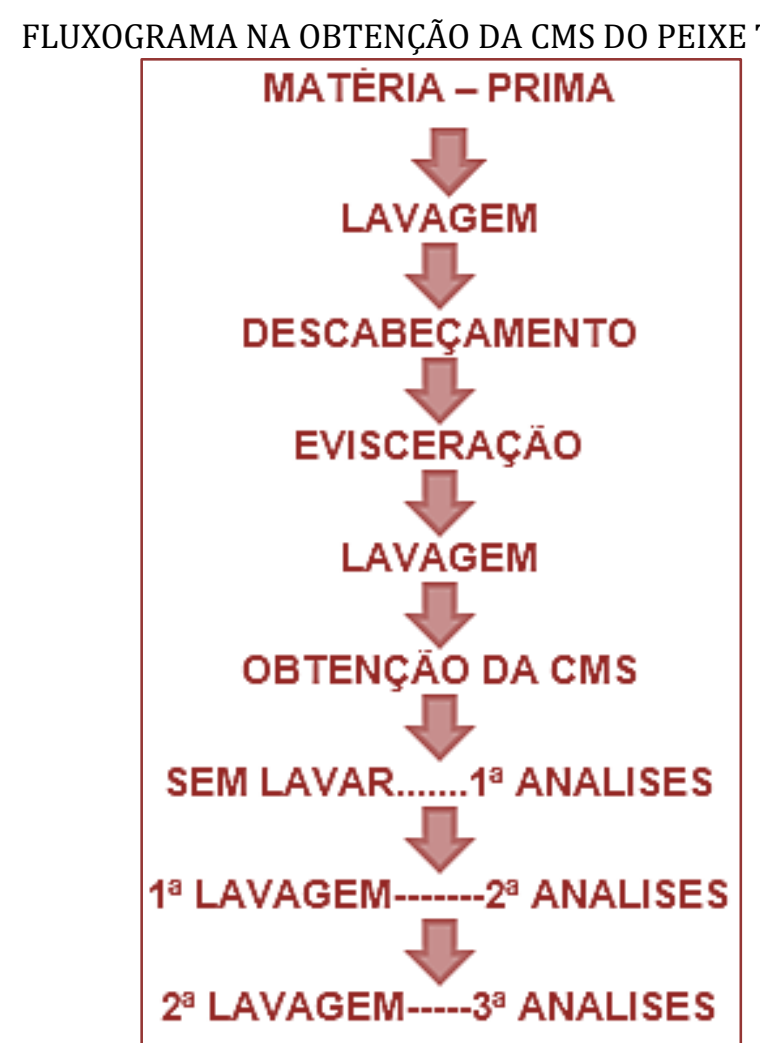

Figura 1 - Peixe descabeçado e evicerado

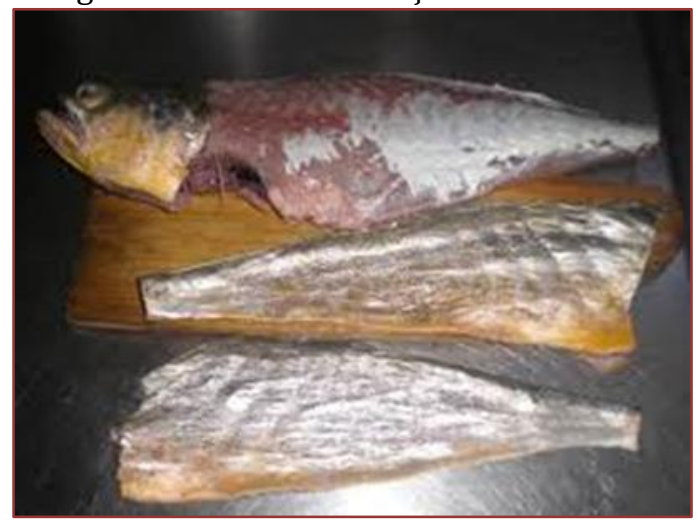

Fonte: http://paraibapesca.blogspot.com.br/2011/07/tirando-o-couro-do-peixe-tibiro.html 
Figura 2 - Obtenção da CMS do peixe Tibiro

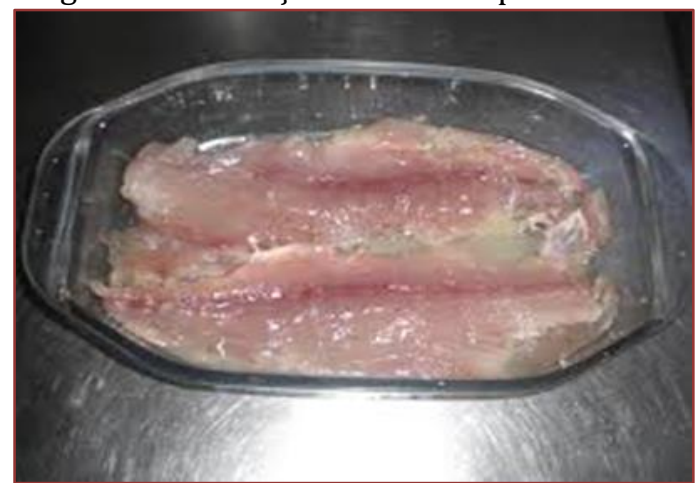

Fonte: http://paraibapesca.blogspot.com.br/2011/07/tirando-o-couro-do-peixe-tibiro.html

Figura 3 - Análise (titulação para determinação da acidez)

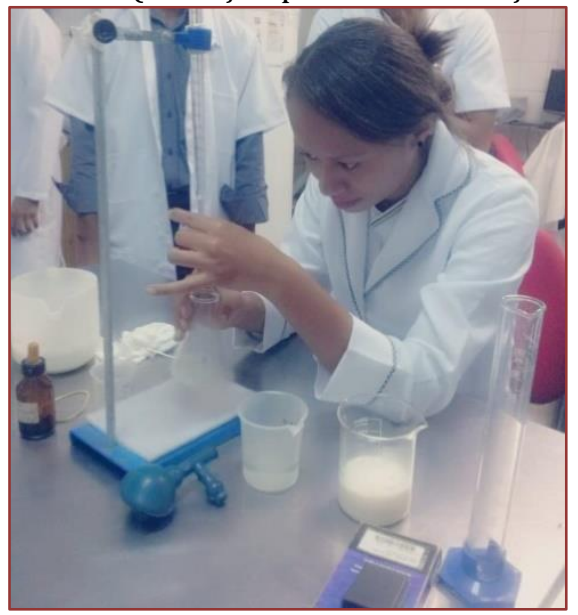

Fonte: Arquivo pessoal

\section{RESULTADOS E DISCUSSÃO}

0 rendimento da extração da CMS do peixe Tibiro foi de 38,90\% em relação ao peixe inteiro. Os valores reportados neste trabalho são menores aos encontrados por Gryschek et al. (2003), que observaram rendimentos de 42,56 em relação ao peixe inteiro para tilápias Vermelha. Ohshima et al. (1993) relataram um rendimento médio de $47 \%$ da extração da CMS de "alaska pollock" (Theragra chalcogramma), em relação aos peixes inteiros. 0 rendimento após o processo de lavagem pode ser influenciado pela eficiência da retirada de água, número de lavagens e tipo de equipamento utilizado.

Os valores referentes à composição centesimal da CMS do peixe Tibiro estão expostos na Tabela 1 . A determinação de umidade é uma das medidas mais importantes e utilizadas na análise de alimentos. A umidade de um alimento está relacionada com sua estabilidade, qualidade e composição, e pode afetar em várias características seja na estocagem, embalagem, processamento e etc. Além disso, a determinação da acidez assim como a determinação do pH são de total importância na análise de alimentos, tendo em vista que através dela podem-se obter dados valiosos na apreciação do processamento e do estado de conservação dos alimentos. Já a determinação do teor de proteínas é umas das etapas mais importantes na análise de uma determinada amostra, nesse caso tem-se o peixe Tibiro. Ele possui um alto teor de proteína, diferente da pescada, que apesar de ter um valor mais alto, possui menos valor proteico. 0 processo de lavagem propiciou remoção de proteínas hidrossolúveis, minerais e lipídios, tornando a CMS lavada uma matéria-prima diferente da CMS não lavada. Foi observado aumento nos teores de umidade na CMS após o processo de lavagem. Este comportamento também foi observado por outros autores (Neiva, 2003; Gryschek et al., 2003;). Isto ocorreu provavelmente devido ao aumento na capacidade de hidratação das proteínas miofibrilares, que estão presentes em grande quantidade na CMS, com a remoção das proteínas sarcoplasmáticas durante a lavagem (Suzuki, 1987). 
Tabela 1: Composição centesimal das CMS lavadas e não lavadas de peixe Tibiro.

\begin{tabular}{|c|c|c|c|c|}
\hline CMS avaliada & Umidade (\%) & Acidez $(\%)$ & 6,87 & 16,58 \\
\hline CMS não lavada & 26,62 & 5,50 & 7,01 & 15,01 \\
\hline CMS lavada (1x) & 22.40 & 1,52 & 7,13 & 14,05 \\
\hline CMS lavada $(2 \mathrm{x})$ & 19,12 & 1,19 & & Proteínas (\%) \\
\hline
\end{tabular}

Os valores de umidade encontrados nas CMS lavadas neste estudo estão muito abaixo aos observados por Lanfer-Marquez e Mira (2005), entre 79,58\% a 88,70\% em amostras de surimi de peixes marinhos de baixo valor comercial (Paralonchurus brasiliensis e Cynoscion virescens), e do Simões et al. (1998) que relataram teores 92,78\% de umidade em CMS lavada de pescada (Cynoscion striatus). Valores de umidade em CMS lavadas podem diferir muito entre si, dependendo do processo de lavagem e retirada de água utilizados.

Observou-se que a acidez das CMS lavada é menor que da CMS não lavada. Como não há conservantes adicionadas na CMS do peixe Tibiro, houve oxidação lipídica, e alterações nas proteínas e na cor da CMS durante armazenamento sob congelamento.

Observou-se que o pH das CMS lavada é menor que da CMS não lavada. 0 aumento do pH pode indicar degradação proteica, com produção de substâncias como amônia e outras aminas. Entretanto, Jesus et al. (2001) encontraram aumentos nos valores de pH de 6,50 para até 7,07 em CMS de peixes amazônicos estocada por 150 dias sob congelamento. 0 comportamento do pH durante o armazenamento, sob congelamento, é dependente da temperatura de estocagem, composição em sais, estado fisiológico, poder tampão das proteínas e ação enzimática (GRYSCHEK et al., 2003). Neste estudo, o processo de lavagem provavelmente alterou a composição de sais e enzimas presentes na CMS e provocou mudanças no $\mathrm{pH}$ durante o período de armazenamento.

Observou-se diminuição nos teores de proteína nas CMS lavadas, que provavelmente ocorreu devido à remoção da maioria das proteínas solúveis sarcoplasmáticas. Tal fato também foi observado por outros autores (Gryschek et al. 2003; Adu et al., 1983), que reportaram consideráveis perdas de proteína e outros componentes hidrossolúveis após o processo de lavagem de CMS de tilápia e "rockfish".

\section{CONCLUSÕES}

Os resultados indicam que a Carne Mecanicamente Separada do peixe Tibiro é uma alternativa viável para o aproveitamento de peixes com baixo preço comercial.

Diante disso, quanto mais lavagens sofrer a CMS, maiores serão as perdas das proteínas, assim, ocasionando um produto final sem tantas qualidades nutricionais.

\section{REFERÊNCIAS}

[1] ADU, G. A.; BABBITT, J. K.; CRAWFORD, D. L. Effect of washing on the nutritional and quality characteristics of dried minced rockfish flesh. Journal of Food Science, v. 48, p. 1053-1055, 1983.

[2] BORdignon, A. C.; SOUZA, B. E. de; BOHNEnBERGER, L.; HILBIG, C. C.; FEIDEN, A.; BOSCOLO, W. R. Elaboração de croquete de tilápia do Nilo (Oreochromis niloticus) a partir de CMS e aparas do corte em ' $V$ ' do filé e sua avaliação físico-química, microbiológica e sensorial. Acta Scientiarum. Animal Sciences Maringá, v. 32, n. 1, p. 109-116, 2010.

[3] IAL - INSTITUTO ADOLF LUTZ. Normas analíticas do Instituto Adolfo Lutz: Métodos Químicos e Físicos para Análise de Alimentos. 4 ed. São Paulo, 2008. p. 70 - 98.

[4] DURÃES, J. P. Obtenção, caracterização da carne mecanicamente separada de bagre africano (Clarias gariepinus) e avaliação de sua estabilidade durante estocagem sob congelamento. 2009. 71 f. Dissertação (Mestrado) Faculdade de Zootecnia e Engenharia de Alimentos - Universidade de São Paulo, São Paulo.

[5] FELTES, M. M. C.; CORREIA, J. F. G.; BEIRÃO, L. H.; BLOCK, J. M.; NINOW, J. L.; SPILLER, V. R. Alternativas para a agregação de valor aos resíduos da industrialização de peixe. R. Bras. Eng. Agríc. Ambiental, v.14, n.6, p.669-677, 2010.

[6] GRYSCHEK, S. F. B.; OETERER, M.; GALLO, C. R. Characterization and frozen storange stability of minced Nile tilapia (Oreochromis niloticus) and red tilapia (Oreochromis spp.). Journal os Aquatic Food Product Techology, v. 12, n. 3, p. 57-69, 2003. 
[7] HOSDA, C. S.; NANDI, F.; GRASSELLI, S. L. S. Elaboração de nuggets de tilapia do nilo (Oreochromis niloticus) com diferentes concentrações de CMS adicionado de sálvia e alecrim e sua avaliação físico-química, microbiologica e sensorial. Trabalho de Conclusão de Curso - Tecnologia em Alimentos, Universidade Federal do Paraná - Campus Medianeira. Medianeira, 2013.

[8] JESUS, R. S.; LESSI, E.; TENUTA-FILHO, A. Estabilidade química e microbiológica de minced fish de peixes amazônicos durante o congelamento. Ciência e Tecnologia de Alimentos, v. 21, n. 2, p. 144-148, 2001.

[9] KIRSCHNIK, P. G.; MACEDO-VIEGAS, E. M. Efeito da lavagem e da adição de aditivos sobre a estabilidade de carne mecanicamente separada de tilápia do Nilo (Oreochromis niloticus) durante estocagem a $-18^{\circ} \mathrm{C}$. Ciênc. Tecnol. Aliment., Campinas, 29(1): 200-206, jan.-mar. 2009.

[10] LANFER-MARQUEZ, U. M.; MIRA, N. V. M. Avaliação da composição centesimal, aminoácidos e mercúrio contaminante de surimi. Ciência e Tecnologia de Alimentos,v. 25, n. 4, p. 665-671, 2005.

[11] MINOZZO, M. G. Patê de pescado: alternativa para incremento da produção nas indústrias pesqueiras. 2010. 228 f. Tese de doutorado em Tecnologia de Alimentos, Universidade Federal do Paraná.

[12] NEIVA, C. R. P. Obtenção e caracterização de minced fish de sardinha e sua estabilidade durante a estocagem sob congelamento. 2003. f. 78. (Mestrado em Alimentos e Nutrição) Faculdade de Ciências Farmacêuticas da Universidade de SãoPaulo, São Paulo, 2003.

[13] OHSHIMA, T.; SUZUKI, T.; KOIZUMI, C. New developments in surimi technology. Trends in Food Science \& Technology, v. 4, p. 157-163, 1993.

[14] SARY, C.; FRANCISCO, J. G. P.; DALLABONA, B. R.; MACEDO, R. E. F. de; GANECO, L. N.; KIRSCHNICK, P. G. Influência da lavagem da carne mecanicamente separada de tilápia sobre a composição e aceitação de seus produtos. Rev. Acad., Ciênc. Agrár. Ambient., Curitiba, v. 7, n. 4, p. 423-432, out./dez. 2009.

[15] SIMÕES, D. R. S.; PEDROSO, M. A.; RUIZ, W. A.; ALMEIDA, T. L. Hambúrgueres formulados com base protéica de pescado. Ciência e Tecnologia de Alimentos, v. 18, n. 4, p. 414-420, 1998.

[16] SUZUKI, T. Tecnologia de las proteínas de pescado y krill. Zaragoza: Acribia, p. 230, 1987. Autor a ser contatado: Franky Soedirlan Resosemito, IFMA São Luís - Campus Maracanã. franky.resosemito@ifma.edu.br. 


\section{Capítulo 13}

Caracterização físico-química e composição mineral de diferentes variedades do fruto mirtilo (Vaccinium myrtillus)

\section{Guilherme Augusto Rebelatto}

Bruna Albiero

Gláucia Freiberger

Rúbia Agostineto

Adriana Biasi Vanin

José Carlos Azzolini

Analu Mantovani

Resumo: Conhecido como fruto da longevidade, o mirtilo melhora os níveis de colesterol, previne doenças e é rico em antocianinas. A caracterização físico-química e mineral de diferentes cultivares auxilia na comprovação de seus efeitos nutricionais, importantes na dieta humana. A presente pesquisa objetivou determinar as características físicoquímicas, a quantidade de carotenoides e a composição mineral de três variedades do fruto mirtilo, Emerald, Misty e $0^{\prime} N$ Neal. A variedade $0^{\prime} N e a l$, quando comparada às outras variedades, apresentou maior conteúdo de minerais com destaque para o cálcio com $3487,68 \mathrm{mg} / \mathrm{Kg}$. A variedade Emerald apresentou o maior teor de umidade $(85,90 \%)$ e de carotenoides (2\%), enquanto o cultivar Misty teve maior porcentagem de Ácido Cítrico e Ácido Málico, respectivamente 1,34\% e 0,94\%, contendo também o maior valor de nitrogênio 5955,50 mg/Kg.

Palavras-Chave: Mirtilo; Compostos bioativos; Composição mineral. 


\section{INTRODUÇÃO}

Uma alimentação equilibrada auxilia na promoção da saúde e do bem-estar, pois oferece nutrientes e componentes necessários ao organismo. Cada grupo alimentar possui uma função específica no corpo humano e o conhecimento da composição mineral dos alimentos a serem ingeridos é fundamental no desenvolvimento da dieta (VERRUCK et al., 2018).

Uma alimentação adequada é aquela onde o consumo de frutas e hortaliças estão presentes, pois são considerados alimentos de grandes recursos nutricionais, que contém diversas vitaminas, minerais e compostos bioativos importantes no metabolismo humano (SCHIASSI et al., 2018).

Os compostos bioativos diferenciam-se pela estrutura química e podem ser divididos em grupos de acordo com suas funções, como por exemplo, a atividade antioxidante, o equilíbrio do sistema hormonal, atividade antibacteriana, entre outros. Os compostos fenólicos são conhecidos pelo seu potencial antioxidante, estes absorvem radicais livres inibindo a cadeia de iniciação ou interrompendo a cadeia de propagação das reações oxidativas, auxiliando na prevenção de doenças (BOMFIM et al., 2017).

Conhecido como fruto da longevidade, o mirtilo pertence ao grupo de pequenas frutas e é o que apresenta maior conteúdo de compostos bioativos como carotenoides que também possui potencial antioxidante (SOUZA, 2017). O fruto é uma baga de cor azul-escuro, de formato achatado, coroada pelos lóbulos persistentes do cálice e com aproximadamente 1 a 2,5 cm de diâmetro e 1,5 a $4 \mathrm{~g}$ de peso (OLIVEIRA, 2012).

O consumo de antioxidantes naturais como os compostos fenólicos é muito importante, pois auxiliam não somente na redução lipídica em tecidos vegetais, mas também em animais, e quando incorporado na alimentação humana pode reduzir o risco de desenvolvimento de patologias, como arteriosclerose e câncer (FERNANDES, 2019).

O mirtilo e seus produtos são conhecidos pela sua elevada concentração de polifenóis totais (RODRIGUES, 2017), por serem ricos em flavonoides, como as antocianinas, os flavonóis e os flavan-3-óis ou catequinas; taninos condensados (proantocianidinas, PAC) e hidrolisáveis (elagitaninos e galotaninos); e ácidos fenólicos (hidroxibenzóico e hidroxicinâmico) (SANTOS et al., 2016).

Como são encontrados sob diferentes variedades, e existe uma crescente demanda por alimentos que tragam algum benefício à saúde, a caracterização físico-química e a determinação da composição mineral das diferentes variedades torna-se importante. Diante disto, com intuito de ampliar os conhecimentos acerca do fruto e contribuir com o desenvolvimento sustentável dos campos medicinais e farmacológicos a presente pesquisa objetivou determinar as características físico-químicas, a quantidade de carotenoides e a composição mineral de três variedades do fruto mirtilo, Emerald, Misty e O’Neal.

\section{MATERIAL E MÉTODOS}

As três cultivares Emerald, Misty e O’Neal foram cedidas pela empresa Empório do Mirtilo. Os frutos foram colhidos no mês de outubro de 2019 no município de Itá, no oeste de Santa Catarina, coordenadas $27^{\circ} 17^{\prime}$ $51.071^{\prime \prime}$ S e $52^{\circ} 22^{\prime} 8.126^{\prime \prime}$ W e congelados para posteriores análises.

\subsection{DETERMINAÇÃO DO pH}

Para análise do $\mathrm{pH}$, as amostras foram diluídas por meio da homogeneização de $10 \mathrm{~g}$ da polpa dos frutos, em $90 \mathrm{~mL}$ de água destilada e, conforme metodologia aplicada por Pfaffenbach (2003), a leitura do $\mathrm{pH}$ foi realizada com pHmetro digital da marca Quimis, calibrado com dois pontos 4,0 e 7,0 com três casas decimais.

\subsection{DETERMINAÇÃO DOS MINERAIS}

Os minerais dos frutos foram determinados através de um espectrômetro de absorção atômica modelo AANALYST 800 da marca Perkin-Elmer com queimador de chama de ar acetileno. 0 nitrogênio foi analisado após digestão sulfúrica enquanto que os minerais: potássio, fósforo, cálcio, magnésio, cobre, zinco, ferro, manganês, e enxofre foram determinados após digestão nitroperclórica, conforme metodologia descrita por Tedesco et al. (1995). 


\subsection{DETERMINAÇÃO DO TEOR DE ÁGUA}

Para determinar a umidade dos frutos, utilizou-se os métodos descritos pela AOAC (1990). Pesou-se cerca de 5 gramas de amostra (polpa + casca) em um vidro relógio previamente seco em estufa a $103{ }^{\circ} \mathrm{C}$ e tarado em balança analítica, e desidratou-se a amostra por um período de 2 horas em estufa na mesma temperatura. Posteriormente o vidro relógio foi arrefecido em dessecador durante uma hora e repetiu-se a pesagem. 0 cálculo do teor de umidade foi realizado através da Equação 1.

$$
\frac{g(\text { água })}{100 g}=\frac{P 1-P 2}{P 1-P 3} \times 100
$$

Onde:

P1= Peso do vidro relógio com a amostra úmida.

P2= Peso do vidro relógio com a amostra seca.

P3= Peso do vidro relógio vazio.

0 resultado é expresso em grama de água por $100 \mathrm{~g}$ de peso fresco.

\subsection{DETERMINAÇÃO DE CAROTENOIDES}

Os carotenoides totais foram determinados por metodologia adaptada de Rodriguez-Amaya (1999). Homogeneizou-se cerca de 1,66 gramas de celite com 5 gramas de amostra em $50 \mathrm{~mL}$ de acetona resfriada durante 1 minuto. 0 homogenato resultante foi filtrado sob vácuo e transferido para um balão volumétrico de $50 \mathrm{~mL}$, aferindo o mesmo com acetona. 0 extrato cetônico foi conduzido para um funil de separação contendo $25 \mathrm{~mL}$ de éter de petróleo. Adicionou-se cerca de $100 \mathrm{~mL}$ de água e descartou-se a parte inferior da mistura, repetiu-se por 5 vezes até a remoção completa da acetona. Após retirar toda a fase aquosa, o volume final foi anotado e através de um espectrofotômetro leu-se a concentração de carotenoides em um comprimento de onda de $450 \mathrm{~nm}$. Os resultados, foram expressos em $\mu \mathrm{g} . \mathrm{g}-1$ de massa fresca.

\subsection{DETERMINAÇÃO DA ACIDEZ TITULÁVEL}

Para realização da acidez titulável, adaptou-se a metodologia descrita pela AOAC (1990). Pesou-se 100g da polpa do mirtilo e adicionou-se em $250 \mathrm{~mL}$ de água em ebulição. Manteve-se em água fervente durante 1 hora, após arrefecida, filtrou-se a solução sob vácuo. A solução filtrada foi transferida para um balão volumétrico de $500 \mathrm{~mL}$ aferido com água destilada. Uma alíquota de $25 \mathrm{~mL}$ dessa solução foi diluída 1:10. Um volume de $100 \mathrm{~mL}$ da solução diluída foi então titulado através de fenolftaleína, utilizando-se uma solução de $\mathrm{NaOH}$ 0,1 N. Anotou-se o volume gasto na titulação. Os resultados foram obtidos pela Equação 2, tanto para o ácido málico quanto para o ácido acético.

$$
\frac{g(\text { ácido orgânico })}{100 \mathrm{~g}}=0,005 \times \text { VTit } \times M M
$$

Onde:

VTit = Volume do titulante gasto na titulação.

MM = Massa molar do ácido orgânico.

Os resultados obtidos foram expressos em grama de ácido orgânico por $100 \mathrm{~g}$ de amostra.

\subsection{DETERMINAÇÃO DE AÇÚCAR}

Os sólidos solúveis foram determinados através de um refratômetro manual da marca Digit, Modelo 103/107 e seus resultados foram expressos na escala ${ }^{\circ}$ Brix. 


\section{RESULTADOS E DISCUSSÃO}

As três variedades do mirtilo são pertencentes ao grupo Southem highbush. Os resultados das análises físico-químicas e do teor de carotenoides são apresentados na Tabela 1.

Tabela 1 - Resultados das análises

\begin{tabular}{|c|c|c|c|}
\hline Parâmetros & Emerald & Misty & O'neal \\
\hline Umidade (\%) & $85,90^{a}$ & $85,31^{\mathrm{a}}$ & $84,93^{\mathrm{a}}$ \\
\hline Ácido Cítrico (\%) & $1,24 \mathrm{~b}$ & $1,34 \mathrm{~b}$ & $0,86^{a}$ \\
\hline Ácido Málico (\%) & $0,87 \mathrm{~b}$ & $0,94 \mathrm{~b}$ & $0,60^{\mathrm{a}}$ \\
\hline $\begin{array}{l}\text { Carotenoides ( } \mu \mathrm{g} \cdot \mathrm{g}- \\
\text { 1) }\end{array}$ & $2,00^{\mathrm{b}}$ & $1,95 \mathrm{~b}$ & $1,65^{\mathrm{a}}$ \\
\hline pH & $2,95^{\mathrm{a}}$ & $3,64^{b}$ & $2,82^{\mathrm{a}}$ \\
\hline Açúcares ( ${ }^{\circ}$ Brix) & $14,00^{\mathrm{a}}$ & $12,00^{\mathrm{a}}$ & $13,00^{\mathrm{a}}$ \\
\hline
\end{tabular}

*Médias seguidas de mesma letra não diferem estatisticamente entre si pelo teste de Tukey a 5\% de probabilidade.

A análise dos resultados permite verificar que não existe diferença significativa para a umidade das três variedades estudadas. 0 pH do mirtilo ficou na faixa entre 2,82 e 3,64. Baixos valores de pH são importantes para retenção de antocianinas (STANQUEVIS, 2013). Os valores de sólidos solúveis encontrados para as diferentes cultivares de mirtilo variam entre $12^{\circ}$ e $14^{\circ}$ Brix.

Quanto aos conteúdos de ácido cítrico, ácido málico e carotenoides, não foram evidenciadas diferenças significativas entre as variedades Emerald e Misty. Baixos níveis de carotenoides também foram encontrados por Jacques et al. (2009), mostrando que as espécies selecionadas são pobres neste pigmento. Os resultados dos compostos minerais dos frutos são expressos pela Tabela 2.

Tabela 2 - Resultado das análises de compostos minerais.

\begin{tabular}{|c|c|c|c|}
\hline$(\mathrm{mg} / \mathrm{Kg})$ & Emerald & Misty & O'neal \\
\hline $\mathbf{M n}$ & 13,48 & 22,73 & 33,94 \\
\hline $\mathbf{F e}$ & 3,18 & 4,49 & 4,98 \\
\hline $\mathbf{C u}$ & 1,08 & 0,36 & 1,35 \\
\hline $\mathbf{Z n}$ & 2,78 & 3,71 & 4,77 \\
\hline $\mathbf{K}$ & 1510,64 & 1909,47 & 1337,57 \\
\hline $\mathbf{C a}$ & 2489,01 & 2880,08 & 3487,68 \\
\hline $\mathbf{M g}$ & 67,08 & 67,17 & 98,60 \\
\hline $\mathbf{P}$ & 25,21 & 28,45 & 36,62 \\
\hline $\mathbf{S}$ & 49,90 & 45,97 & 72,83 \\
\hline $\mathbf{N}$ & 516,47 & 5955,50 & 4704,79 \\
\hline
\end{tabular}

As três variedades estudadas possuem em suas composições minerais, importante na dieta humana. É relevante destacar que o teor de minerais nos frutos pode variar muito de acordo com a fertilidade e adubação do solo em que é cultivado, seu trato durante crescimento e poda, além das condições climáticas da região, entre outros. 0 valor de nitrogênio, se dá principalmente por ser o elemento mais exigido pela planta durante seu cultivo. 0 mesmo acontece com o potássio adicionado ao solo durante o ciclo vegetativo de plantas (SANTOS, 2004). A variedade Misty, quando comparada as demais, apresentou concentrações superiores de nitrogênio e potássio, sendo este último, indispensável no organismo humano, pois participa do equilíbrio ácido-base (CAMPOS et al., 2010).

O cálcio, em conjunto com a vitamina D, quando consumido, auxilia na fortificação dos ossos, dentes e unhas. 0 seu alto teor nos cultivares analisados se dá pela função do cálcio manter a firmeza dos frutos e melhorar sua taxa de maturação (SILVEIRA et al., 2007).

A variedade 0’Neal tem o maior valor de cálcio juntamente com o maior valor de enxofre, possivelmente é decorrente da acidificação do solo, altos valores de enxofre nos frutos são encontrados para solo com maior acidez. A variedade O'neal também apresentou o maior valor de cobre, mineral que interfere na pigmentação e consequentemente, no teor de carotenoides, fato este, comprovado nesta pesquisa. 


\section{CONCLUSÃO}

O estudo permitiu avaliar a diferença entre as variedades sob todos os aspectos estudados. As três variedades apresentam valores de minerais, importantes na dieta humana. Mesmo em um mesmo estágio de maturação, existem diferenças na composição mineral de carotenoides entre as variedades estudadas. As análises confirmaram a presença de compostos bioativos nos frutos.

\section{REFERÊNCIAS}

[1] AOAC. (1990). Official Methods of Analysis. Agricultural Chemicals; Contaminants; Drugs. Volume 1, 15th. Assoociation of Official Analytical Chemists, Arlington, EUA. Disponível em: https://law.resource.org/pub/us/cfr/ibr/002/aoac.methods.1.1990.pdf.

[2] Campos, E. M. F., Rogoni, T. T., Massocatto, C. L., Diniz, K. M., Caetano, J., Dragunski, D. C. (2010). Quantificação de minerais em sucos industrializados. Disponivel em: https://www.revistas.unipar.br/index.php/saude/article/view/3398/2301

[3] Bomfim, M. P., Lima, G. P. P., Vianelo, F., José, A. R. S. (2017). Caracterização dos compostos bioativos em frutas e hortaliças adquiridas no comercio de Padova - Itália. Disponível em: https://www.redalyc.org/jatsRepo/813/81353563003/htmL/index.htmL\#gf5

[4] Fernandes, L. A. (2019). Antioxidantes naturais para aplicação em alimentos. TCC (Graduação em Engenharia dos Alimentos) Universidade Federal de Uberlândia, Patos de Minas. Disponível em: http://repositorio.ufu.br/bitstream/123456789/28519/1/AntioxidantesNaturaisPara.pdf.

[5] Oliveira, P. F. M. (2012). Influência dos fatores ambientais, de produção e do grau de amadurecimento nas propriedades antioxidantes e antimutagénicas de diferentes cultivares de Vaccinium spp, produzidas em Portugal. Faculdade de Ciência e Tecnologia. Disponível em: https://run.unl.pt/handle/10362/7700

[6] Pfaffenbach, L. B., Castro, J. V., Carvalho, C. R. L., Rossetto, C. J. (2003). Efeito da atmosfera modificada e da refrigeração na conservação pós-colheita de manga espada vermelha. Revista Brasileira de Fruticultura. Disponível em: https://www.scielo.br/scielo.php?script=sci_arttext\&pid=S0100$29452003000300012 \& \operatorname{lng}=e n \& n r m=i s o \& t \operatorname{lng}=p t$

[7] Rodrigues. (2017). Estudo preliminar da atividade antioxidante do extrato bruto de mirtilo em modelo de úlcera gástrica. Revista Anais do SIEPE. Disponível em: http://200.132.146.161/index.php/siepe/article/view/30289/15803

[8] Rodriguez-Amaya, D. B. (1999) A guide to carotenoid analysis in food. Washington: ILSI Press. Disponível em: http://beauty-review.nl/wp-content/uploads/2014/11/A-guide-to-carotenoid-analysis-in-foods.pdf

[9] Santos, A. M., Freire, C. J. S., Gonçalves, E. D., Coutinho, E. F., Herter, F. G. (2004) A cultura do Mirtilo. Embrapa $\begin{array}{lc}\text { Clima } & \text { Temperado. } \\ \text { https://www.infoteca.cnptia.embrapa.br/bitstream/doc/744895/1/documento121.pdf }\end{array}$

[10] Santos, I. C., Silva, M. A., Albuquerque, T. G., Costa, H. S. (2016). Avaliação dos teores de fenólicos e flavonoides totais em frutos. http://repositorio.insa.pt/bitstream/10400.18/4187/1/Poster_CINSA_Frutos_FINAL.pdf

[11] Schiassi, M. C. E. V., Souza, V. R., Lago, A. M. T., Campos, L. G., Queiroz, F. (2018) Fruits from the Brazilian Cerrado region: Physico-chemical characterization, bioactive compounds, antioxidants activities, and sensory evaluation. Disponível em: https://www.sciencedirect.com/science/article/abs/pii/S0308814617317454

[12] Silveira, N. G. A., Vargas, P. N., Rosa, C. S. (2007). Teor de polifenóis e composição química do mirtilo do grupo highbush. Disponível em: http://serv-bib.fcfar.unesp.br/seer/index.php/alimentos/article/view/176/184

[13] Souza, V. R. D. (2017). Tratamento térmico com vapor e adição de xantana para preservação de compostos bioativos fenólicos e da atividade antioxidante de polpas de mirtilo. (Dissertação de mestrado) Universidade Federal de Pelotas, Pelotas. Disponível em: http://www.repositorio.ufpel.edu.br/handle/prefix/3473.

[14] Stanquevis, R.(2013). Otimização de obtenção de um extrato aquoso de milho roxo (Zea mays L.) rico em antocianinas e perfil de degradação. (Dissertação de mestrado) Universidade de São Paulo, São Paulo. Disponível em: https://www.teses.usp.br/teses/disponiveis/9/9131/tde-17012014132805/publico/DissertacaoCorrigidaReginaStanquevis.pdf

[15] Tedesco, M. J., Gianello, C., Bissani, C. A., Bohnen, H., Volkweiss, S. J. (1995). Analise de solo, plantas e outras matérias. 2. ed. Porto Alegre.

[16] Verruck, S., Prudencio, E. S., Silveira, S. M. (2018). Compostos bioativos com capacidade antioxidante e antimicrobiana em frutas. Disponível em: http://www.revistas.udesc.br/index.php/revistacsbea/article/view/13312 


\section{Capítulo 14}

Quantification of ascorbic acid in Amazon fruits

\section{Andrezza da Silva Ramos}

João Pedro Gallo de Oliveira

Jaqueline de Araújo Bezerra

Marcos Batista Machado

Abstract: Natural functional foods, especially fruits, have become quite popular for their beneficial effects on human health and in the treatment of diseases. The Myrtaceae family has fruits that are highly appreciated for their organoleptic properties and for being rich in natural antioxidant substances. Non-conventional fruits of Myrtaceae were selected and the ascorbic acid content was quantified by the HPLC-PDA analytical method. It is the first report on the determination of ascorbic acid in fresh pulps of these fruits considered non-conventional food plants (PANC) endemic in the Amazon, and the results reveal that they can be considered as functional foods due to the high antioxidant and nutritional potentials attributed to vitamin C .

Key Words: Myrtaceae; functional foods; HPLC-PDA; healthy food; prevention of diseases. 


\section{INTRODUCTION}

Functional foods have become quite popular in the treatment of certain diseases. There are several scientific studies that prove that unconventional tropical fruits can be considered functional foods ${ }^{1}$, because they have high antioxidant and nutritional potential $2 ; 3 ; 4 ; 5 ; 6$. Amazonian fruits like camu-camu (Myrciaria dubia McVaugh), considered the Brazilian fruit with the highest amount of vitamin C (1 to 3 grams / 100g of fresh fruit (FF) $7 ; 8$, whose pleasant citrus juice is rich in anthocyanins ${ }^{9}$. Other examples are the species of araçá-boi (Eugenia stipitata McVaugh), araçá (Psidium cattleianum Sabine) ${ }^{10 ; 11}$, and araçá-pera (Psidium acutangulum) ${ }^{2}$ amazonian guavas that are great sources of polyphenols and vitamin C. These substances are responsible for their pharmacological potential 6;12.

Therefore, functional foods can be classified as a source of safe ingredient for consumption, such as dietary fiber, polyunsaturated fatty acid, protein, peptide, amino acid, minerals, vitamin, antioxidant and bioactive phenolic substance ${ }^{13}$. In this context, the demand of several countries for fruits rich in vitamin $\mathrm{C}$ has increased due to their potential in the prevention and treatment of chronic diseases ${ }^{14 ;} 15$. Several fruits rich in vitamin $\mathrm{C}$ stood out in reducing oxidative stress, such as the powder of the whole bergamot fruit (66.93 $\pm 0.05 \mathrm{mg} \mathrm{AAE} \mathrm{/} 100 \mathrm{~g})^{16}$, chilto powder (Solanum betaceum) $(117,0 \pm 10,2 \mathrm{mg} \mathrm{AAE} / 100 \mathrm{gFF}){ }^{17}$, the fruits of the Indian Himalayan region Phyllanthus emblica $(33,15 \mathrm{mg} / \mathrm{gFF})$ and Morus alba $(29,53$ $\mathrm{mg} / \mathrm{gFF}){ }^{18}$, black currant $(162,73 \mathrm{mg} / 100 \mathrm{gFF})$, blackberry $(45,07 \mathrm{mg} / 100 \mathrm{gFF})$ and straberry $(57,95$ $\mathrm{mg} / 100 \mathrm{gFF}$ ) ${ }^{19}$. As oxidative stress plays a crucial role in Alzheimer's disease (AD) ${ }^{20}$, antioxidant supplements like vitamin $\mathrm{C}$, which have antioxidant properties, can be used to reduce oxidative stress.

According to Leffa et al ${ }^{21}$, the amount of vitamin C in acerola juice (Malpighia emarginata DC) contributes to the reduction of oxidative stress in obesogenic conditions. Vitamin C can effectively mitigate the toxicity of a protein called 3R-tau, which acts on AD causing neuro degeneration ${ }^{22}$. The consumption of fruits rich in vitamin $\mathrm{C}$ or related bioactives can reduce the risk of Alzheimer's disease ${ }^{12}$ and other diseases. Young et al ${ }^{23}$ characterized vascular enhancers of small endogenous molecules and multimerization inhibitors. The results obtained suggest that the multimerization of proteins in the brain during aging is not restricted to neuronal molecules only, and vitamin C can act by inhibiting catecholamine-dependent multimerization. Other properties of vitamin C is the antimicrobial effect against Staphylococcus aureus, Bacillus subtilis and Pseudomonas aeruginosa bacterium, and moderate effect against Salmonella typhimurium, Escherichia coli, Enterococcus feacium and Candida albicans observed in the ethanol extract of the mature arbutus species (Arbutus unedo L.), which presented vitamin C ( $48 \mathrm{mg} / 100 \mathrm{~g}$ of FF) as a major component ${ }^{24,25}$.

A good diet composed of fruits rich in vitamin $\mathrm{C}$ can be important for residents of poor regions ${ }^{26}$ because, acting in conjunction with the polyphenols present in fruits, vitamin $\mathrm{C}$ increases health protection, since tropical fruits are rich in phytochemicals with potential antioxidants and anticancer 27; 28. There are several unconventional or little-known fruits, which have a high content of vitamin $\mathrm{C}$ in their composition and, therefore, can also be considered functional foods and included in the human diet in order to promote health.

The best-known species of Myrtaceae in Brazil are guava (Psidium spp.), jabuticaba (Myrciaria cauliflora) and pitangueira (Eugenia uniflora). The fruits of Myrtaceae are presented in capsular form with a single core, or resemble small rounded olives, or in baciform form with several seeds, such as guava $29 ; 30 ; 31 ; 32$. Most of the unconventional fruits of the Amazon are usually obtained from nature or grown only for the local market and sold in the natural way, resulting in low added value $33 ; 34 ; 35$. The study of chemical composition, biological properties and nutritional assessment of fruits can enable regional economic growth due to the valorization of fruit species in the Amazon region 36; 37; 38 .

\section{MATERIALS AND METHODS}

The fruits were collected at the Adolpho Ducke Forest Reserve (RFAD), Manaus, Amazonas, Brazil. And they were analyzed fresh. 


\subsection{SAMPLE PREPARATION FOR ASCORBIC ACID EXTRACTION}

The extraction was done in a commercial blender (5 min) and ice bath, in triplicate, based on the extraction method of Ramos and collaborators ${ }^{2}$. Each extract was centrifuged (BioSpin) for 5 min and the supernatant was filtered through a membrane of PTFE, $500 \mu \mathrm{L}$ was homogenized in $500 \mu \mathrm{L}$ of the mobile phase (acidified water with 1\% formic acid (pH 3.5), $20 \mathrm{mM}\left(\mathrm{NH}_{4}\right){ }_{2} \mathrm{HPO}_{4}$, and $\left.0.015 \% \mathrm{MPA}\right)$, then subjected to HPLC-PDA analysis.

\subsection{SAMPLE ANALYSIS AND PREPARATION CONDITIONS FOR QUANTIFICATION OF L - (+) - ASCORBIC ACID}

Calibration was performed by injecting a standard solution of $L-(+)$ - ascorbic acid (AA) (1 mg mL-1) in triplicate, prepared on each day of analysis with 1\% MPA solution and then diluted to obtain the final concentrations of $1,20,40,60,80$ and $100 \mu \mathrm{g} \mathrm{mL}^{-1}$.

The equipment used was a Thermo Scientific, Acella ${ }^{\circledR}$ high performance liquid chromatograph (HPLC) with automatic injector and quaternary pump, coupled to the Thermo® triple quadrupole mass spectrometer (TQS) (San Jose, CA, USA), with an electrospray ionizer operating in positive (+) and negative (-) modes, equipped with a photodiode array detector (DAD). Column used: Phenomenex Hydro$\mathrm{RP}(150 \mathrm{~mm} \times 4.5 \mathrm{~mm}, 4 \mu \mathrm{m})$; flow: $600 \mu \mathrm{L} / \mathrm{min}$; injection volume: $10 \mu \mathrm{L}$, oven temperature: $25^{\circ} \mathrm{C}$ and, shelf temperature containing the samples: $4^{\circ} \mathrm{C}$; UV range: 200 to $600 \mathrm{~nm}$. The XCalibur® software was used for data acquisition.

\section{RESULTS AND DISCUSSION}

\subsection{QUANTIFICATION OF ASCORBIC ACID IN AMAZONIC FRUITS OF MYRTACEAE}

Table 1 shows the concentration values of ascorbic acid (AA) determined in the fruits of Myrtaceae. The adopted method has good linearity in the concentration range of 1-100 $\mu \mathrm{g} \mathrm{mL}^{-1}$ and good resolution for AA $(0.4<$ Rs < 1.3$)$. The lowest detectable concentration (detection limit - LD) for AA was calculated as the signal to noise ratio (S / N) of 3: 1 and the quantification limit (LQ) determined was obtained from the lowest concentration whose value of $\mathrm{S} / \mathrm{N}$ was greater than 10: 139; 40. The LD and LQ for AA determined in this study are similar to those reported in the literature when it comes to vitamin $\mathrm{C}$ and fruits and vegetables. Therefore, this AA quantification method can be considered sensitive based on the linearity and the LD and LQ values.

Table 1 Ascorbic acid (AA) content ( $\mathrm{n}=3$ ) in fresh fruits (FF) from Amazon Myrtaceae.

\begin{tabular}{|c|c|c|}
\hline Species & $\begin{array}{c}\mathrm{AA} \\
(\mathrm{mg} / 100 \mathrm{~g} \mathrm{FF})\end{array}$ & Parameters \\
\hline Myrcia minutiflora Sagot. & $<\mathrm{LQ}$ & \multirow{10}{*}{$\begin{array}{c}\text { LD: } 0.0221 \mu \mathrm{AU} \\
\text { LQ: } 0.0737 \mu \mathrm{AU} \\
\text { Eq Linear: } \mathrm{y}=7406.1 \mathrm{x}+2364.9 \\
\mathrm{R}^{2}: 0.9993\end{array}$} \\
\hline Myrcia bracteata DC & $<\mathrm{LQ}$ & \\
\hline Myrcia fenestrata DC & $109.08 \pm 19.69$ & \\
\hline Myrcia sylvatica (G. Mey.) DC & $<\mathrm{LQ}$ & \\
\hline Myrcia magnoliifolia DC. & $616.46 \pm 75.63$ & \\
\hline Syzigium cumini L. & $71.65 \pm 19.12$ & \\
\hline Calyptranthes spruceana 0. Berg. & $<\mathrm{LQ}$ & \\
\hline Eugenia stipitata McVaugh & $45.91 \pm 15.23$ & \\
\hline Eugenia punicifolia (Kunth) DC & $<\mathrm{LQ}$ & \\
\hline Eugenia uniflora L. & $56.18 \pm 13.0$ & \\
\hline
\end{tabular}

Among all the fruit samples analyzed, M. magnoliifolia has the highest AA value $(616.46 \pm 75.63 \mathrm{mg} / 100$ gFF). In Brazil, this fruit is still unknown and is not yet cultivated, being found only in the wild form, as well as M. fenestrata, which has the second highest AA result.

Chemical studies with Myrtaceae fruits reveal the presence of phenolic substances and vitamins (A, C and E), responsible for the anti-inflammatory, antioxidant and hypocholesterolemic action 41; 42; 43. However, this is the first report on the determination of ascorbic acid in fresh pulps of these unconventional fruits from the Amazon. 
The physiological states of maturation and appearance of fruits are related to climatic conditions and the type of region. These factors can influence the color, flavor and quantity of the chemical constituents contained in these fruits. Thus, the levels of ascorbic acid can vary in the pulps during maturation ${ }^{44}$.

\section{CONCLUSION}

The results obtained reveal the importance of chemical and nutritional studies of unconventional fruits. The inclusion of functional natural foods can be an alternative for populations that cannot consume industrialized supplements. Thus, through healthy eating, it would be possible to prevent and even combat certain diseases related to oxidative processes, such as diabetes, Alzheimer's and cancer.

\section{ACKNOWLEDGMENT}

The authors would like to thank FAPEAM, CAPES (Edital No. 047/2012 - Pró-Amazônia) and FINEP for the financial support.

\section{REFERENCES}

[1] DANTAS, A. M. et al. Bioaccessibility of phenolic compounds in native and exotic frozen pulps explored in Brazil using a digestion model coupled with a simulated intestinal barrier. Food Chemistry, v. 274, p. 202-214, Feb 2019. ISSN 0308-8146. Disponível em: < <Go to ISI>://WOS:000448141800026 >.

[2] RAMOS, A. S. et al. Chemical characterization and antioxidant capacity of the araca-pera (Psidium acutangulum): An exotic Amazon fruit. Food Research International, v. 75, p. 315-327, Sep 2015. ISSN 0963-9969. Disponível em: <<Go to ISI >://WOS:000359961800037 >.

[3] CANDIDO, T. L. N.; SILVA, M. R.; AGOSTINI-COSTA, T. S. Bioactive compounds and antioxidant capacity of buriti (Mauritia flexuosa L.f.) from the Cerrado and Amazon biomes. Food Chemistry, v. 177, p. 313-319, Jun 2015. ISSN 0308-8146. Disponível em: <<Go to ISI>://WOS:000350093400042 >.

[4] NERI-NUMA, I. A. et al. Evaluation of the antioxidant, antiproliferative and antimutagenic potential of aracaboi fruit (Eugenia stipitata Mc Vaugh - Myrtaceae) of the Brazilian Amazon Forest. Food Research International, v. 50, n. 1, p. 70-76, Jan 2013. ISSN 0963-9969. Disponível em: <<Go to ISI >://WOS:000315613900009 >.

[5] BORGES, G. D. S. C. et al. Chemical characterization, bioactive compounds, and antioxidant capacity of jussara (Euterpe edulis) fruit from the Atlantic Forest in southern Brazil. Food Research International, v. 44, n. 7, p. 21282133, 2011. ISSN 0963-9969.

[6] AZEVEDO, L. et al. Camu-camu (Myrciaria dubia) from commercial cultivation has higher levels of bioactive compounds than native cultivation (Amazon Forest) and presents antimutagenic effects in vivo. Journal of the Science of Food and Agriculture, v. 99, n. 2, p. 624-631, Jan 2019. ISSN 0022-5142. Disponível em: < <Go to ISI>://WOS:000453912300016>.

[7] JUSTI, K. C. et al. Nutritional composition and vitamin C stability in stored camu-camu (Myrciaria dubia) pulp. Archivos Latinoamericanos De Nutricion, v. 50, n. 4, p. 405-408, Dec 2000. ISSN 0004-0622.

[8] FRACASSETTI, D. et al. Ellagic acid derivatives, ellagitannins, proanthocyanidins and other phenolics, vitamin $\mathrm{C}$ and antioxidant capacity of two powder products from camu-camu fruit (Myrciaria dubia). Food Chemistry, v. 139, n. 1-4, p. 578-588, Jul 1 2013. ISSN 0308-8146. Disponível em: < <Go to ISI>://WOS:000318200900080 >.

[9] CASTRO, D. R. G. et al. Improvement of the Bioavailability of Amazonian Juices Rich in Bioactive Compounds Using Glow Plasma Technique. Food and Bioprocess Technology, v. 13, n. 4, p. 670-679, Apr 2020. ISSN 1935-5130. Disponível em: <<Go to ISI >://WOS:000520478100009>.

[10] MEDINA, A. L. et al. Araca (Psidium cattleianum Sabine) fruit extracts with antioxidant and antimicrobial activities and antiproliferative effect on human cancer cells. Food Chemistry, v. 128, n. 4, p. 916-922, Oct 2011. ISSN 0308-8146. Disponível em: < <Go to ISI >://WOS:000292491400013 >.

[11] ASTRID GARZON, G. et al. Determination of Carotenoids, Total Phenolic Content, and Antioxidant Activity of Araza (Eugenia stipitata McVaugh), an Amazonian Fruit. Journal of Agricultural and Food Chemistry, v. 60, n. 18, p. 4709-4717, May 9 2012. ISSN 0021-8561. Disponível em: <<Go to ISI>://WOS:000303696000036 >.

[12] AGARWAL, P. et al. Association of Strawberries and Anthocyanidin Intake with Alzheimer's Dementia Risk. Nutrients, v. 11, n. 12, p. 11, Dec 2019. Disponível em: <<Go to ISI>://WOS:000506917800222 >.

[13] ANVISA, A. N. D. V. S. Diretrizes básicas para análise e comprovação de propriedades funcionais e ou de saúde alegadas em rotulagem de alimentos. NETO, G. V. 1999. 
[14] BELWAL, T. et al. Phytopharmacology of Acerola (Malpighia spp.) and its potential as functional food. Trends Food Sci. Technol., v. 74, p. 99-106, 2018. ISSN 0924-2244.

[15] PRAKASH, A.; BASKARAN, R. Acerola, an untapped functional superfruit: a review on latest frontiers. J. Food Sci. Technol. (New Delhi, India), v. 55, n. 9, p. 3373-3384, 2018. ISSN 0022-1155.

[16] GABRIELE, M. et al. Citrus bergamia powder: Antioxidant, antimicrobial and anti-inflammatory properties. J. Funct. Foods, v. 31, p. 255-265, 2017. ISSN 1756-4646.

[17] ORQUEDA, M. E. et al. Chemical and functional characterization of seed, pulp and skin powder from chilto (Solanum betaceum), an Argentine native fruit. Phenolic fractions affect key enzymes involved in metabolic syndrome and oxidative stress. Food Chem., v. 216, p. 70-79, 2017. ISSN 0308-8146.

[18] BHATT, I. D. et al. Nutraceutical potential of selected wild edible fruits of the Indian Himalayan region. Food Chem., v. 215, p. 84-91, 2017. ISSN 0308-8146.

[19] DONNO, D. et al. Foodomics for mulberry fruit (Morus spp.): Analytical fingerprint as antioxidants' and health properties' determination tool. Food Res. Int., v. 69, p. 179-188, 2015. ISSN 0963-9969.

[20] BETTERIDGE, D. J. What is oxidative stress? Metabolism - Clinical and Experimental, v. 49, n. 2, p. 3-8, 2000. ISSN 0026-0495. Disponível em: < https://doi.org/10.1016/S0026-0495(00)80077-3 >. Acesso em: 2020/06/26.

[21] LEFFA, D. D.; DA SILVA, J.; PETRONILHO, F. C. Acerola ( Malpighia emarginata DC.) juice intake protects against oxidative damage in mice fed by cafeteria diet. Food Research International, v. 77, p. 649-656, 2015.

[22] XU, C. et al. Co-Expression of Three Wild-Type 3R-Tau Isoforms Induces Memory Deficit via OxidationRelated DNA Damage and Cell Death: A Promising Model for Tauopathies. Journal of Alzheimers Disease, v. 73, n. 3, p. 1105-1123, 2020. ISSN 1387-2877. Disponível em: <<Go to ISI>://WOS:000512319400023 >.

[23] YOUNG, K. Z. et al. Thiol-mediated and catecholamine-enhanced multimerization of a cerebrovascular disease enriched fragment of NOTCH3. Experimental Neurology, v. 328, p. 14, Jun 2020. ISSN 0014-4886. Disponível em: $<<$ Go to ISI $>$ ://WOS:000527888300025 >.

[24] SALEM, I. B. et al. Exploring the nutraceutical potential and biological activities of Arbutus unedo L. (Ericaceae) fruits. Ind. Crops Prod., v. 122, p. 726-731, 2018. ISSN 0926-6690.

[25] HABIB, S. et al. Preparation of Progressive Antibacterial LDPE Surface via Active Biomolecule Deposition Approach. Polymers, v. 11, n. 10, p. 15, Oct 2019. Disponível em: <<Go to ISI >://WOS:000495382700173 >.

[26] KUMARI, A. et al. Antioxidant activities, metabolic profiling, proximate analysis, mineral nutrient composition of Salvadora persica fruit unravel a potential functional food and a natural source of pharmaceuticals. Front. Pharmacol., v. 8, p. 61/1-61/14, 2017. ISSN 1663-9812.

[27] ULLAH, M. F. et al. Ascorbic acid in cancer chemoprevention: translational perspectives and efficacy. Curr. Drug Targets, v. 13, n. 14, p. 1757-1771, // 2012. ISSN 1389-4501.

[28] DE SOUZA, V. R. et al. Amazon Fruits Inhibit Growth and Promote Pro-apoptotic Effects on Human Ovarian Carcinoma Cell Lines. Biomolecules, v. 9, n. 11, p. 15, Nov 2019. Disponível em: < <Go to ISI>://WOS:000502267900068 >.

[29] SOBRAL, M.; DE SOUZA, M. A. D. Thirteen new Amazonian Myrtaceae. Phytotaxa, v. 238, n. 3, p. 201-229, Dec 2015. ISSN 1179-3155. Disponível em: < <Go to ISI>://WOS:000367136600001 >.

[30] CALIARI, C. P.; SOUZA, V. C.; MAZINE, F. F. Two new species of Myrcia (Myrtaceae) from Brazilian Atlantic Forest. Phytotaxa, v. 267, n. 3, p. 201-210, Jul 2016. ISSN 1179-3155. Disponível em: < <Go to ISI>://WOS:000381944700003 >.

[31] RIBEIRO, J. E. H., M. J. G. VICENTINI, A. SOTHERS, C. A. COSTA, M. A. S. BRITO, J. M.SOUZA, M. A. D. MARTINS, L. H. P. LOHMANN, L. G. ASSUNÇÃO, P. A. C. L. PEREIRA, E. C.; SILVA, C. F. M., M. R.PROCÓPIO, L. C. Flora da Reserva Ducke. Manaus - AM: INPA-DFID, 1999.

[32] OLIVEIRA, M. L. et al. Reserva Ducke: A biodiversidade amazônica através de uma grade. Manaus: Áttema Design Editorial, 2008.

[33] SCHRECKINGER, M. E. et al. Berries from South America: A Comprehensive Review on Chemistry, Health Potential, and Commercialization. Journal of Medicinal Food, v. 13, n. 2, p. 233-246, Apr 2010. ISSN 1096-620X. Disponível em: <<Go to ISI $>$ ://WOS:000277190700001 >.

[34] KUSKOSKI, E. M. et al. Wild fruits and pulps of frozen fruits: antioxidant activity, polyphenols and anthocyanins. Ciencia Rural, v. 36, n. 4, p. 1283-1287, Jul-Aug 2006. ISSN 0103-8478. Disponível em: <<Go to ISI >://BIOABS:BACD200600417995 >.

[35] KINUPP, V. F.; LORENZI, H. Plantas Alimentícias Não Convencionais (PANC) no Brasil. 1aa Plantarum, 2014. 768 ISBN 9788576714467. 
[36] SONIA S. ANAND et al. Food Consumption and its Impact on Cardiovascular Disease:

[37] Importance of Solutions Focused on the Globalized Food System. JOURNAL OF THE AMERICAN COLLEGE OF CARDIOLOGY, v. 66, n. 14, p. 1590 - 614, 2015. ISSN 0735-1097/\$36.00.

[38] ANDREW D. JONES; EJETA, G. A new global agenda for nutrition and health: the importance of agriculture and food systems. Bulletin of the World Health Organization. 94: 228-229 p. 2016.

[39] DJIDEL, S. et al. Medicinal plants used traditionally in the Algerian folk medicine for gastrointestinal disorders and hypertension: total polyphenols, flavonoids and antioxidant activity. Acta Hortic., v. 854, n. Proceedings of the XIIIth International Conference on Medicinal and Aromatic Plants, 2009, p. 59-65, 2010. ISSN 0567-7572.

[40] ICH, I. C. O. H. Q2b: Validation of analytical procedures: Methodology: US FDA Federal Register. 621996.

[41] SNYDER, L. R.; KIRKLAND, J. J. Introduction to modern liquid chromatography. 2. New York: Wiley Interscience, 1979.

[42] DE SOUZA SCHMIDT GONCALVES, A. E.; LAJOLO, F. M.; GENOVESE, M. I. Chemical Composition and Antioxidant/Antidiabetic Potential of Brazilian Native Fruits and Commercial Frozen Pulps. Journal of Agricultural and Food Chemistry, v. 58, n. 8, p. 4666-4674, Apr 28 2010. ISSN 0021-8561. Disponível em: < <Go to ISI>://WOS:000276782100019>.

[43] PERALTA-BOHORQUEZ, A. F. et al. Analysis of Volatile Compounds of Sour Guava (Psidium guineense Swartz) Fruit. Journal of Essential Oil Research, v. 22, n. 6, p. 493-498, Nov-Dec 2010. ISSN 1041-2905. Disponível em: $<<$ Go to ISI $>$ ://WOS:000284247000008 $>$.

[44] SERAGLIO, S. K. T. et al. Nutritional and bioactive potential of Myrtaceae fruits during ripening. Food Chemistry, v. 239, p. 649-656, Jan 2018. ISSN 0308-8146. Disponível em: <<Go to ISI>://WOS:000408740200078>.

[45] BRANDAO, T. S. D. et al. Changes in enzymes, phenolic compounds, tannins, and vitamin C in various stages of jambolan (Syzygium cumini Lamark) development. Ciencia E Tecnologia De Alimentos, v. 31, n. 4, p. 849-855, OctDec 2011. ISSN 0101-2061. Disponível em: <<Go to ISI>://WOS:000298887000003 >. 


\section{Capítulo 15}

Utilização de peróxido de hidrogênio no controle de microrganismos e vida de prateleira de morangos frescos (Fragaria x ananassa Duch)

\section{Ariane Barbo Maretoli \\ Kaelly Siqueira Horbe \\ Paula Fernanda Pinto da Costa}

Resumo: Este trabalho objetivou avaliar o efeito do tempo de imersão de morangos em solução de peróxido de hidrogênio 8\% (SPH8) na redução da microbiota de morangos frescos e na vida de prateleira. Os morangos foram imersos em SPH8 durante 0 a 60 minutos, drenados e utilizados para avaliação da contagem total de aeróbios mesófilos (CT) e vida de prateleira. O tempo de imersão em SPH8 influenciou na CT, reduzindo de 2 a 4 log UFC/g ao longo do tempo, resultando CT residual inferior a $2 \log \mathrm{UFC} / \mathrm{g}$. A vida de prateleira dos morangos submetidos aos tratamentos variou de 6 a 10 dias, quando refrigerados. Conclui-se que a imersão em SPH8 por 50 ou 60 min reduz a microbiota dos frutos o suficiente para estender a vida de prateleira dos frutos, passando de 2 para 10 dias sob refrigeração e de 2 para 5 dias, em temperatura ambiente.

Palavras-Chave: sanitização, frutas minimamente processadas, armazenamento. 


\section{INTRODUÇÃO}

O morango (Fragaria x ananassa Duch) é um fruto consumido em muitos países por suas características sensoriais atrativas e nutricionais bem definidas, além de conter substâncias bioativas, como bioflavonóides, substâncias que auxiliam na redução do risco de incidência de alguns tipos de câncer (ROCHA et al., 2008).

Apesar de ser um fruto não climatérico, é altamente perecível, resultando em um curto prazo de validade (aproximadamente 5 dias a $0-4^{\circ} \mathrm{C}$ ) devido as injúrias mecânicas, deterioração fisiológica, perda de água, ataques fúngicos e alta taxa respiratória (ADAY et al., 2013; DEL-VALLE et al., 2005; VARGAS et al., 2006), o que causa um rápido declínio de qualidade que limita a sua comercialização, consumo e, por consequência, resulta em perdas econômicas (VALENZUELA et al., 2015).

Por ser consumido principalmente cru, microrganismos podem ser veiculados pela sua ingestão, caso não sejam adequadamente sanitizados, podendo neste caso, veicular alguns tipos de doenças transmitidas por alimentos (DTA'S).

Diversos surtos de DTA'S foram reportados tendo o morango como veículo, como por exemplo, sua associação a surtos de hepatite A, Escherichia coli, Salmonella spp., Norovírus, Cyclospora cayatanensis e Staphylococcus aureus (FDA, 2011; JAY, 2005; LAIDLER et al., 2013; NOTERMANS et al., 2004; SIVAPALASINGAM et al., 2004).

Desta forma, é necessária a adoção de procedimentos para que os frutos crus sejam seguros para o consumo, o que pode ser obtido através da lavagem, seguida da sanitização com agentes químicos ou físicos, de forma a reduzir/eliminar a população de micro-organismos deterioradores e patogênicos a níveis aceitáveis. É importante que esses procedimentos cumpram os seus objetivos sem prejudicar as características sensoriais e nutricionais dos alimentos (JOSHI et al., 2013; JUNG et al., 2017; SÃO JOSÉ et al., 2014).

Pesquisas recentes têm buscado alternativas ao uso do cloro, dentre as opções estão as tecnologias que não deixam resíduos, como o ozônio e o uso de peróxido de hidrogênio. 0 peróxido de hidrogênio $\left(\mathrm{H}_{2} \mathrm{O}_{2}\right)$, objeto deste estudo, apresenta várias vantagens, como a redução de custos do tratamento de resíduos, respeitando as regulamentações ambientais vigentes além de ser um dos oxidantes mais eficientes, em virtude do elevado teor de oxigênio liberado (VOLOSHIN, HALDER, LAWAL, 2007; NTAINJUA et al., 2011; SAMANTA, 2008).

Este trabalho objetivou avaliar o efeito da imersão de morangos em solução de peróxido de hidrogênio na redução da microbiota de morangos frescos e na sua vida de prateleira.

\section{MATERIAL E MÉTODOS}

\subsection{MATERIAL}

O estudo foi conduzido no período de fevereiro a junho de 2019. Foram utilizados morangos em ponto de maturação adquiridos em mercados locais, selecionados de acordo com a uniformidade de cor, tamanho e ausência de injúrias mecânicas, fisiológicas e enxaguados em água corrente para posterior utilização nos ensaios.

Os morangos foram submetidos à imersão em solução de peróxido de hidrogênio 8\%, variando-se o tempo de imersão de 0 a 60 minutos. Paralelo aos ensaios foi realizado um ensaio "controle", onde os morangos foram imersos somente em água destilada e avaliados no tempo inicial e ao final de 60 minutos.

Após o tempo de imersão, os pseudofrutos foram drenados e utilizados para avaliação da microbiota residual e vida de prateleira.

A solução de peróxido de hidrogênio 8\% foi preparada a partir de uma solução 30\% (Vetec).

\subsection{AVALIAÇÃO MICROBIOLÓGICA}

A microbiota dos morangos foi avaliada através da contagem total de aeróbios mesófilos, seguindo as técnicas descritas no Manual de métodos de análise microbiológica de alimentos e água (SILVA et al., 2010). 
Para cada tratamento foram armazenadas triplicatas de embalagens plásticas de Polietileno tereftalato contendo três morangos por embalagem. 0 estudo foi conduzido em temperatura ambiente e sob refrigeração $\left(8^{\circ} \mathrm{C}\right)$ e realizado o acompanhamento por observação visual diariamente, para avaliar o processo de deterioração ao longo dos dias de armazenamento.

O tempo total de armazenamento foi definido como o dia anterior ao aparecimento dos primeiros sinais de deterioração (amolecimento, alteração da coloração, aparecimento de micélio).

\subsection{VIDA DE PRATELEIRA}

Para cada tratamento foram armazenadas triplicatas de embalagens plásticas de Polietileno tereftalato contendo três morangos por embalagem. O estudo foi conduzido em temperatura ambiente e sob refrigeração $\left(8^{\circ} \mathrm{C}\right)$ e realizado o acompanhamento por observação visual diariamente, para avaliar o processo de deterioração ao longo dos dias de armazenamento.

0 tempo total de armazenamento foi definido como o dia anterior ao aparecimento dos primeiros sinais de deterioração (amolecimento, alteração da coloração, aparecimento de micélio).

\subsection{ANÁLISE DOS DADOS}

O processamento dos dados foi realizado no programa Microsoft Excel 2010 e expressos a partir de análise descritiva, média de três repetições e construção de gráficos de dispersão, contendo o modelo obtido e seu coeficiente de determinação $\left(\mathrm{R}^{2}\right)$.

\section{RESULTADOS E DISCUSÃO}

Na Figura 1 está apresentado efeito do tempo de imersão de morangos em solução de peroxido de hidrogênio $8 \%$ ou em água sobre a contagem total de aeróbios mesófilos. Como esperado, a simples lavagem em água não foi suficiente para remover os micro-organismos, pois após 60 minutos de imersão a população passou de 5,9 log UFC/g para 5,0 log UFC/g, sendo considerada uma alta carga microbiana residual.

Os morangos apresentam uma superfície irregular e inúmeros aquênios, os quais funcionariam como sítio de proteção para microrganismos (NASCIMENTO E SILVA, 2010), sendo necessário o uso de substancias químicas ou métodos físicos para a remoção efetiva.

No entanto, a contagem total de aeróbios mesófilos foi reduzida através da imersão dos frutos na solução de peróxido de hidrogênio 8\%, sendo esta resposta dependente do tempo de exposição (Figura 2), ocorrendo uma redução de aproximadamente $4 \log \mathrm{UFC} / \mathrm{g}$ ao completar 60 minutos de tratamento, onde os frutos apresentaram contagens inferiores a $2 \log \mathrm{UFC} / \mathrm{g}$, o que é desejável e contribui para a sua conservação.

Figura 1 - Efeito do tempo de imersão de morangos em solução de peroxido de hidrogênio 8\% sobre a contagem total de aeróbios mesófilos.

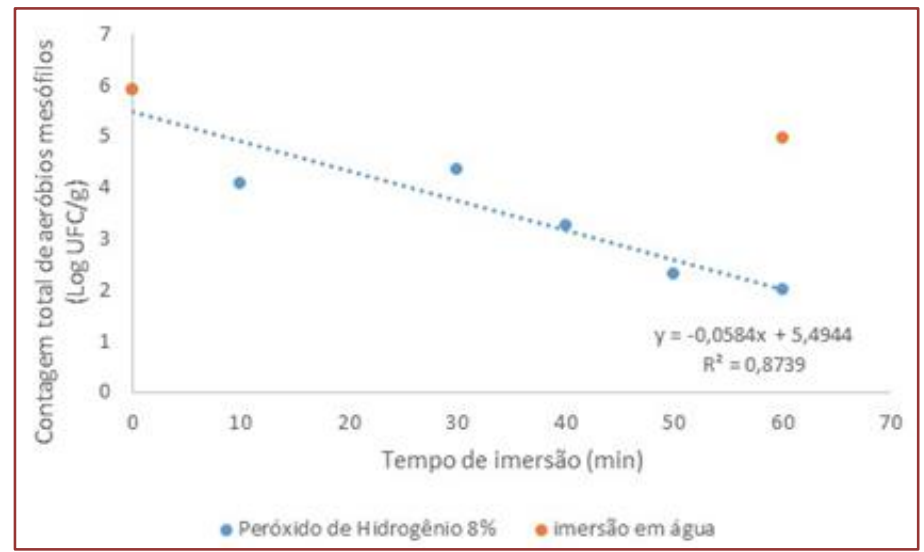


A observação dos pontos da curva demonstra que houve uma variação na taxa de eliminação dos microrganismos, provavelmente por se tratar de uma microbiota heterogênea, com respostas diferentes a ação do peróxido. As populações mais sensíveis aos ROS (espécies reativas de oxigênio) são eliminadas inicialmente e outros micro-organismos mais resistentes tendem a permanecer viáveis por mais tempo, em função dos seus mecanismos de defesa, relacionados à respostas enzimáticas que poderiam neutralizar a ação do peróxido ou estruturais, como diferenças de permeabilidade, capacidade de produzir biofilmes ou espessura associadas a parede celular ou parede de esporos (BROWN et al., 2008; BAUGHER, JAYKUS, 2015, MACARISIN et al., 2010).

Os resultados obtidos neste estudo foram comparados com os estabelecidos por órgãos oficiais. No entanto, a legislação brasileira não estabelece limites para a contagem total de micro-organismos, estabelecendo limites para a contagem de coliformes termotolerantes e para a presença de Salmonella sp. (ANVISA, 2001). Em outros países além dos critérios acima mencionados a contagem total e a contagem de bolores e leveduras também são consideradas, como por exemplo, na União Europeia os limitem máximos para a contagem total (EC 2073/2005) é de 5 logs UFC/g.

Na figura 2 está apresentado o efeito do tempo de imersão dos morangos em solução de peróxido de hidrogênio 8\% sobre o tempo de armazenamento. Observa-se que os morangos armazenados em temperatura ambiente apresentaram uma curta duração, variando de dois a cinco dias, dependendo do tratamento, onde os morangos imersos por 50 ou 60 minutos na solução de peróxido de hidrogênio ampliaram em três dias o seu tempo de duração.

Figura 2 - Efeito do Peróxido de Hidrogênio sobre a vida de prateleira dos morangos armazenados em temperatura ambiente e sob refrigeração.

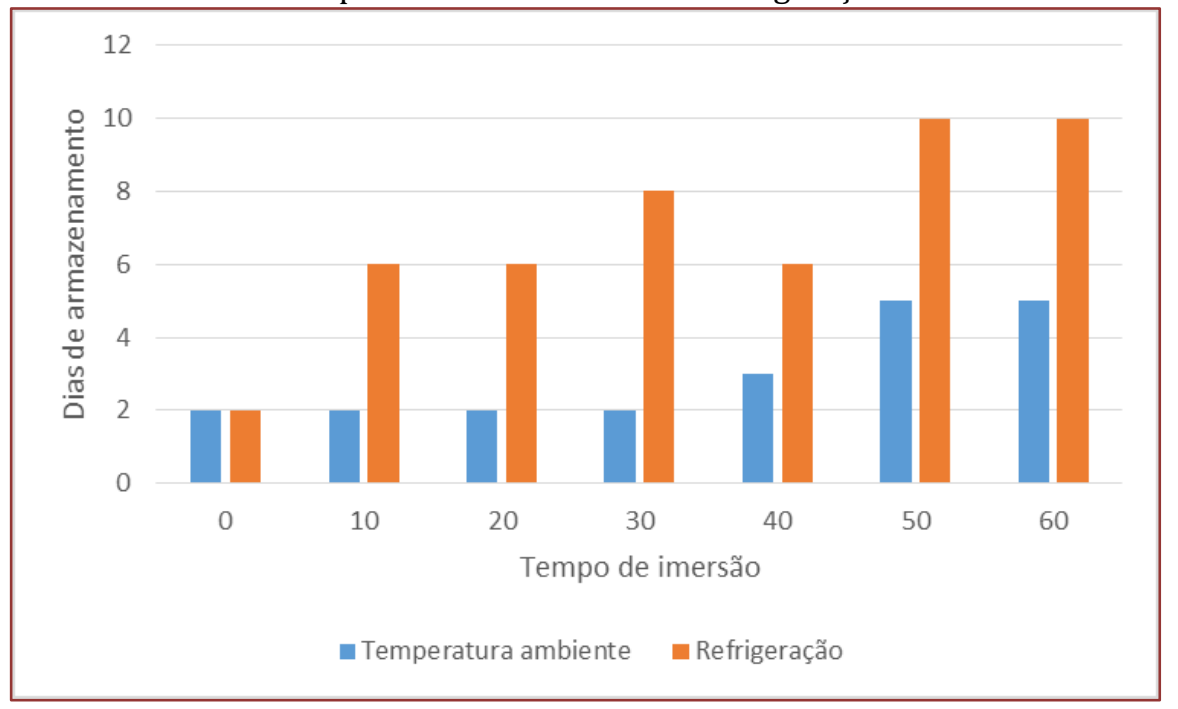

Os morangos armazenados sob refrigerados apresentaram uma duração de dois a 10 dias, onde os morangos que não foram submetidos a imersão apresentaram o menor tempo de duração enquanto tratamentos de 50 e 60 minutos foram conservados por dez dias, indicando que a imersão em peróxido aliada a refrigeração apresenta uma excelente alternativa para o prolongamento da conservação dos pseudofrutos.

Alexandre, Brandão e Silva (2012) observaram que durante o armazenamento sob temperatura refrigerada, a lavagem com soluções de peróxido de hidrogênio resultou em morangos com menor carga microbiana, quando comparados aos demais tratamentos. No entanto, produziu perdas significativas de atributos de qualidade, como cor e conteúdo total de antocianinas.

As principais alterações observadas que limitaram a conservação foram alterações da cor, amolecimento e aparecimento de micélio, provavelmente associadas principalmente a sensibilidade dos produtos disponíveis na época da execução deste estudo. 


\section{CONCLUSÕES}

A imersão em peróxido de hidrogênio por 50 ou 60 minutos reduziu em $4 \log$ UFC/g a contagem total de aeróbios mesófilos e prolongou a vida de prateleira dos frutos, passando de 2 para 10 dias sob refrigeração e de 2 para 5 dias, em temperatura ambiente.

\section{REFERÊNCIAS}

[1] ADAY, M. S.; BUYUKCAN, M. B.; CANER, C. Maintaining the quality of strawberries by combined effect of aqueous chlorine dioxide with modified atmosphere packaging. Journal of Food Processing and Preservation, v. 37, n. 5, p. 568-581, 2013.

[2] ALEXANDRE, E. M. C.; BRANDÃO, T. R.S.; SILVA, C. L.M. Assessment of the impact of hydrogen peroxide solutions on microbial loads and quality factors of red bell peppers, strawberries and watercress. Food Control, v. 27, n. 2, p. 362-368, 2012.

[3] BAUGHER, J.L.; JAYKUS, L.A. Microbiota natural de framboesas (Rubus idaeus) e morangos (Fragaria $\times$ ananassa): levantamento microbiano, isolamento e identificação bacteriana e caracterização de biofilme. XI International Rubus and Ribes Symposium, p. 421-526, 2015.

[4] BROWN, S.H.; YARDEN, O.; GOLLOP, N.; CHEN, S.; ZVEIBIL, A.; BELAUSOV, E.; FREEMAN, S. Expressão diferencial de proteínas em Colletotrichum acutatum: alterações associadas a espécies reativas de oxigênio e falta de nitrogênio implicadas na patogenicidade em morango. Molecular Plant Pathology , v. 9, n. 2, pág. 171-190, 2008.

[5] DEL-VALLE, V.; HERNÁNDEZ, M. P.; GUARDA, A.; GALOTTO, M. J. Development ofa cactus-mucilage edible coating (Opuntia ficusindica) and its application to extend strawberry (Fragaria ananassa) shelf-life. Food Chemistry, v. 91, n. 4, p.751-756, 2005.

[6] GARCIA, L. C. Aplicação de coberturas comestíveis em morangos minimamente processados. Dissertação Programa de Pós-Graduação em Engenharia de Alimentos. Universidade Estadual de Campinas, São Paulo, 2009.

[7] JAY, J. M. Biofilmes. Microbiologia de Alimentos, Porto Alegre: Artmed, v. 6, p. 673-674, 2005.

[8] JOSHI, K.; MAHENDRAN, R.; ALAGUSUNDARAM, K.; NORTON, T.; TIWARI, B.K Novos desinfetantes para produtos frescos. Trends in Food Science \& Technology, v. 34, n. 1, p. 54-61, 2013.

[9] JUNG, Y.; JANG, H.; GUO, M.; GAO, J.; MATTHEWS, K.R. Eficácia do desinfetante na prevenção da contaminação cruzada de cabeças de alface durante o preparo do varejo. Food Microbiology, v. 64, p. 179-185, 2017.

[10] LAIDLER, M. R.; TOURDJMAN, M.; BUSER, G. L.; HOSTETLER, T.; REPP, K. K.; LEMAN.; KEENE, W. E. Escherichia coli 0157: H7 infections associated with consumption of locally grown strawberries contaminated by deer. Clinical Infectious Diseases, v. 57, n. 8, p. 1129-1134, 2013.

[11] MACARISIN, D.; DROBY, S.; BAUCHAN, G.; WISNIEWSKI, M. Superoxide anion and hydrogen peroxide in the yeast antagonist-fruit interaction: a new role for reactive oxygen species in postharvest biocontrol. Postharvest Biology and Technology, v. 58, n. 3, p. 194-202, 2010.

[12] NASCIMENTO, M. S.; SILVA, N. Tratamentos químicos na sanitização de morango (Fragaria vesca L.). Brazilian Journal of Food Technology, v. 13, n. 1, p. 7-11, 2010.

[13] NOTERMANS, S.; ZANDVOORT-ROELOFSEN, J.S.; BECZNER, J.; BARENDSZ, A.W. Perfil de risco para os morangos. Food Protection Trends, v. 24, n. 10, p. 730-739, 2004.

[14] NTAINJUA, E. N.; PICCININI, M.; PRITCHARD, J. C.; EDWARDS, J. K.; CARLEY, A. F.; KIELY, C. J.; HUTCHINGS, G. J. Direct synthesis of hydrogen peroxide using ceria-supported gold and palladium catalysts. Catalysis Today, v. 178, n. 1, p. 47-50, 2011.

[15] ROCHA, D. A.; ABREU, C. M. P. D.; CORREAA, A. D.; SANTOS, C. D. D.; FONSECA, E. W. N. D. Análise comparativa de nutrientes funcionais em morangos de diferentes cultivares da região de Lavras-MG. Revista Brasileira de Fruticultura, v. 30, n. 4, p, 1124-1128, 2008.

[16] SAMANTA, C. Direct synthesis of hydrogen peroxide from hydrogen and oxygen: An overview of recent developments in the process. Applied Catalysis A: General, v. 350, n. 2, p. 133-149, 2008. 
[17] SÃO JOSÉ, J.F.B.; RAMOS, A. N.J.; RAMOS, A.M.; VANETTI, M.C.D.; STRINGHETA, P.C.; CHAVES, J.B.P. Descontaminação por aplicação de ultrassom em frutas e vegetais frescos. Food Control, v. 45, p. 36-50, 2014.

[18] SIVAPALASINGAM, S.; FRIEDMAN, C.R.; COHEN, L.; TAUXE, R.V. Produtos frescos: uma causa crescente de surtos de doenças transmitidas por alimentos nos Estados Unidos, 1973 a 1997. Journal of Food Protection, v. 67, n. 10, p. 2342-2353, 2004.

[19] VALENZUELA, C.; TAPIA, C.; LÓPEZ, L., BUNGER, A.; ESCALONA, V.; ABUGOCH, L. Effect of edible quinoa protein-chitosan based films on refrigerated strawberry (Fragaria $\times$ ananassa) quality. Electronic Journal of Biotechnology, v. 18, n. 6, p. 406-411, 2015.

[20] VARGAS, M.; ALBORS, A.; CHIRALT, A.; GONZÁLEZ, M. C. Quality of cold-stored strawberries as affected by chitosan-oleic acid edible coatings. Postharvest Biology and Technology, v. 41, n. 2, p. 164-171, 2006.

[21] VOLOSHIN, Y.; HALDER, R.; LAWAL, A. Cinética da síntese de peróxido de hidrogênio por combinação direta de $\mathrm{H} 2$ e 02 em um micro-reator. Catalysis Today ,v. 125, n. 1-2, p. 40-47, 2007. 


\section{Capítulo 16}

Avaliação de filme a base de fibra de colágeno com adição de óleo essencial de pimenta rosa na conservação pós-colheita de morangos

Suslin Raatz, Thiel

Felipe Ozorio Giacomelli

Mari Silvia Rodrigues de Oliveira

Milena Padilha

Andrine Menna Fontoura

Rosa Cristina Prestes Dornelles

Resumo: Este trabalho teve por objetivo aplicar diferentes filmes elaborados a partir de fibra de colágeno, comparado ao filme de PVC, na conservação de morangos. Foram utilizados morangos in natura higienizados, embalados com filmes e armazenadas sob temperatura de refrigeração $\left(5^{\circ} \mathrm{C}\right)$. As amostras foram analisadas nos tempos $0,4,7$ e 11 dias de armazenamento no que se referem ao aspecto microbiológico quanto à presença de bolores e leveduras e quanto ao teor de umidade nos dias 4 e 11. Os morangos armazenados com o filme de fibra de colágeno com adição de óleo essencial de Pimenta Rosa apresentaram maior teor de umidade no dia 4 do que o filme de fibra de colágeno controle, porém, menores que PVC. Em relação a contagem de bolores e leveduras, os filmes produzidos de fibra de colágeno não apresentaram diferenças significativas quanto ao filme sintético.

Palavras-Chave: biofilme; conservação; microbiologia.

Artigo publicado como resumo expandido em Anais do $7^{\circ}$ Simpósio de Segurança Alimentar. ISBN online 978-65992839-0-1, de 27 a 29 de outubro de 2020, Porto Alegre, RS: Sociedade Brasileira de Ciência e Tecnologia de Alimentos 


\section{INTRODUÇÃO}

A vida útil de frutas e verduras frescas é complexa, influenciada pelas características do produto (respiração, transpiração, produção de etileno, etc.), condições ambientais circundantes (temperatura, composição dos gases e umidade relativa do ar) e desenvolvimento de deterioração (Kilcast e Subramaniam, 2000). Devido à sua alta fragilidade e sua vida útil muito curta, as frutas e verduras contribuem para $45 \%$ das perdas e desperdícios globais de alimentos registrados na cadeia pós-colheita (Gitz et al. 2014), principalmente nos estágios de distribuição e consumo.

Os morangos, devido ao seu metabolismo muito ativo, são altamente perecíveis e têm altas atividades fisiológicas pós-colheita, o que leva a curtos períodos de amadurecimento e senescência que tornam sua comercialização um desafio (Garcia, Martino \& Zaritzky, 1998).

Filmes baseados em biopolímeros são uma resposta possível à demanda por materiais de embalagem ecológicos, onde, juntamente com a biodegradabilidade, são frequentemente derivados de fontes abundantes e renováveis, como no caso do colágeno obtido geralmente a partir de couros bovinos, que são disponíveis em larga escala (Wolf et al. 2009). Os filmes de colágeno apresentam excelentes desempenhos em comparação com outros filmes de proteínas, como baixa solubilidade em água, alta resistência e resistência ao cozimento, devido à microestrutura fibrosa (Xu et al. 2019).

Atualmente, a incorporação de compostos antimicrobianos em filmes e revestimentos comestíveis fornece uma abordagem inovadora para melhorar a segurança microbiana e o prazo de validade dos alimentos (Cagri et al. 2004). Na literatura, já existem estudos com a adição de compostos bioativos aplicados para aumentar a vida útil de morangos, no entanto, a maioria é aplicada à revestimentos, como óleo essencial de menta em matrizes de carboximetilcelulose e quitosana (Shahbazi, 2018), óleo essencial de alho em revestimentos de carboximetilcelulose (Dong e Wang, 2017), óleo essencial de limão e quitosana (Perdones et al. 2012) e cera de abelha e quitosana (Velickova et al. 2013).

O óleo essencial de Pimenta Rosa tem sido relatado em estudos devido a sua atividade antimicrobiana (Dannenberg et al. 2019), no entanto, não foi encontrado trabalhos com a sua adição em filmes de fibra de colágeno para a conservação pós-colheita de morangos.

Conforme exposto, este estudo tem por objetivo avaliar a qualidade de morangos in natura embalados com filmes à base de fibra de colágeno com e sem adição do óleo essencial de Pimenta Rosa, comparados ao filme sintético PVC.

\section{MATERIAL E MÉTODOS}

\subsection{AMOSTRAS}

A Pimenta Rosa foi adquirida desidratada, diretamente com o produtor na cidade de Turuçu - RS. A fibra de colágeno bovina foi fornecida pela Nova Prom Food Ingredients Ltda. (Lins, SP, Brasil). Os morangos (Fragaria sp.) in natura foram comprados no dia de início das análises, diretamente com o produtor, com estágio de maturação completo, produzidos na região de Agudo - RS.

\subsection{EXTRAÇÃO DO ÓLEO ESSENCIAL}

0 óleo essencial de pimenta rosa foi extraído por arraste a vapor, com o uso de equipamento Clevenger. Foram usados $65 \mathrm{~g}$ da pimenta rosa moída em liquidificador e $600 \mathrm{~mL}$ de água destilada.

\subsection{PRODUÇÃO DOS FILMES}

Para a produção dos filmes seguiu-se metodologia proposta por Paglione et al. (2019) com modificações. A solução filmogênica foi preparada com fibra de colágeno a $5 \%$ (p / v) em água destilada e glicerol a $25 \%$ (p / p) (em relação à massa de fibra de colágeno). As soluções formadoras de filme foram aquecidas em banho maria à $70^{\circ} \mathrm{C}$ por 20 min. No filme com adição de óleo essencial de Pimenta Rosa, o mesmo foi adicionado à solução formadora de filme na concentração de $1 \%$ e tween $80(1 \mathrm{~g} / 100 \mathrm{~mL})$. Em seguida, a solução foi espalhada em placas de vidro $(30 \times 21 \mathrm{~cm})$ e secos em estufa com circulação de ar a $25-30{ }^{\circ} \mathrm{C}$ (Marconi ${ }^{\circledR}$ ) por 24 hs. Após a secagem, os filmes foram acondicionados em dessecadores a temperatura de $16^{\circ} \mathrm{C}$. 0 filme PVC foi adquirido no comércio de Santa Maria - RS. 


\subsection{PREPARO DOS TRATAMENTOS}

Primeiramente, os morangos foram lavados em água corrente, após sanitizados em solução de hipoclorito de sódio ( $\mathrm{NaClO}$ ) a 0,003\% por 20 minutos e secos a temperatura ambiente. Após os morangos foram divididos entre os três tratamentos: embalados em plástico de Policloreto de Vinila (PVC), Filme de Fibra de Colágeno (FCC) e Filme de Fibra de Colágeno adicionado de Óleo Essencial (FCOE) de Pimenta Rosa (1\%). Foram acondicionados em torno de $200 \mathrm{~g}$ em cada embalagem e após os filmes foram selados com uma seladora manual de bancada (Cetro®, PFS400) conforme mostra a Figura 1. As amostras foram armazenadas sob temperatura de refrigeração $\left(5^{\circ} \mathrm{C}\right)$ até o momento das respectivas análises. Foram realizadas duas repetições em cada tratamento.

Figura 1: Filme de Fibra de Colágeno com adição de Óleo Essencial de Pimenta Rosa (1\%) desenvolvida selada com morangos.

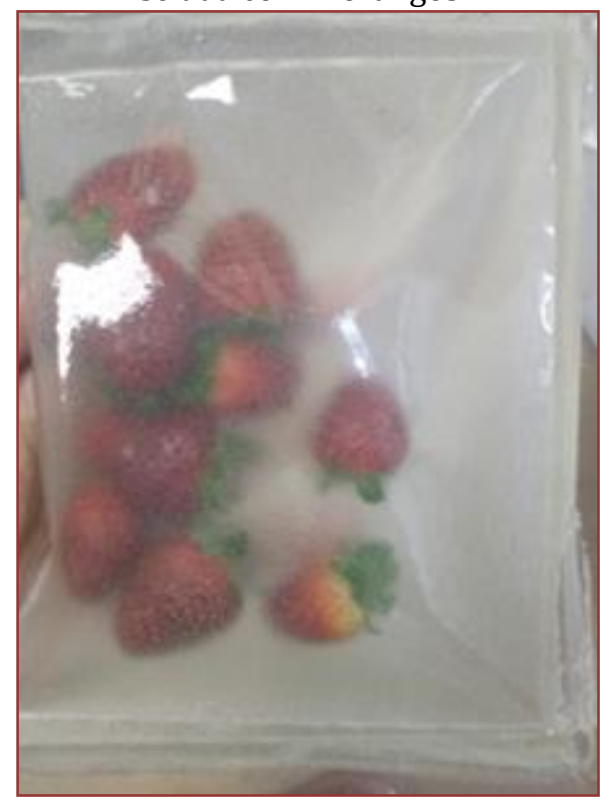

Fonte: Autor.

\subsection{ANÁLISE DE UMIDADE}

A umidade foi realizada em estufa à $105^{\circ} \mathrm{C}$ conforme metodologia do IAL (2008).

\subsection{ANÁLISE MICROBIOLÓGICA}

Os morangos foram avaliados microbiologicamente quanto a presença de bolores e leveduras por cultivo em superfície através do uso do meio BDA (Kasvi®) acidificado com ácido tartárico 10\% (Synth®), a contagem das placas procedeu-se após 5 dias armazenadas em estufa bacteriológica (Biomatic $($ ) à $25^{\circ} \mathrm{C} \pm 5^{\circ} \mathrm{C}$. As análises ocorreram nos tempos zero, quatro, sete e onze dias de armazenamento sob refrigeração, utilizando as metodologias descritas segundo Silva et al. (2001). Os resultados foram expressos em log UFC/g.

\subsection{ANÁLISE ESTATÍSTICA}

Os resultados obtidos foram submetidos à análise de variância significativo ao nível de 5\% de probabilidade $(\mathrm{p}<0,05)$, foi realizada a comparação de médias pelo Teste de Tukey $(\mathrm{p}<0,05)$, utilizandose o programa Statistic 8.0 . 


\section{RESULTADOS E DISCUSSÃO}

Os resultados de umidade são apresentados na Tabela 1. No dia 4, os morangos embalados com o filme FCC apresentaram o menor teor de umidade, no entanto, no dia 11 os filmes FCC e FCOE não foram estatisticamente diferentes entre si. Com o armazenamento os filmes com fibra de colágeno apresentaram diferenças significativas, houve uma perda da umidade com o tempo.

Os morangos embalados com filme PVC apresentaram maiores teores de umidade. No estudo de TanadaPalmu e Grosso (2005), encontraram maiores perdas de peso em morangos embalados com filme de glúten de trigo do que em filme de PVC, como encontrado no presente estudo. De acordo com trabalho de Yamashita et al. (2006), o filme de PVC como é uma barreira ao vapor de água, reduz a taxa de perda de massa do morango pois cria no interior da embalagem uma atmosfera de alta umidade relativa, diminuindo o déficit de pressão de vapor de água e consequentemente a taxa de respiração. Os filmes biodegradáveis geralmente possuem uma permeabilidade de vapor e oxigênio maior, podem causar uma perda de umidade maior, como foi encontrado neste estudo. Na Figura 2 é possível visualizar que em 11 dias os morangos armazenados FCC e FCOE apresentam perda de umidade maior do que do filme PVC.

Tabela 1 - Umidade (\%) de morangos armazenados sob refrigeração $\left(5^{\circ} \mathrm{C}\right)$ com diferentes filmes PVC, FCC e FCOE.

\begin{tabular}{|c|c|c|}
\hline \multirow{2}{*}{ Filme } & \multicolumn{2}{|c|}{ Dias de armazenamento } \\
\hline & 4 & 11 \\
\hline PVC & $92,53^{\mathrm{aA}} \pm 0,01$ & $91,51^{\mathrm{aA}} \pm 0,37$ \\
\hline FCC & $89,34^{\mathrm{cA}} \pm 0,19$ & $85,04^{\mathrm{bB}} \pm 0,05$ \\
\hline FCOE & $90,69 \mathrm{bA} \pm 0,01$ & $85,95^{\mathrm{bB}} \pm 0,85$ \\
\hline
\end{tabular}

Letras minúsculas diferentes nas colunas diferem significativamente $(\mathrm{p}<0,05)$; Letras maiúsculas diferentes nas linhas diferem significativamente $(\mathrm{p}<0,05)$.

PVC: Policloreto de vinila; FCC: Fibra de colágeno controle; FCOE: Fibra de colágeno com adição de 1\% de óleo essencial de Pimenta Rosa.

Os resultados da contagem de bolores e leveduras estão expressos na Tabela 2. Os filmes desenvolvidos de FCC e FCOE não apresentaram diferença estatística com o polímero sintético (PVC), assim, os filmes de fibra de colágeno com e sem adição de óleo essencial de pimenta rosa apresentaram a mesma eficiência que o PVC. Durante o período de armazenamento o filme de PVC apresentou contagem significativamente maior em 11 dias comparando com a sua contagem apresentada em 0 dias, diferente dos filmes FCC e FCOE que apresentam valores significativamente iguais para suas contagens nos dias 0 e 11 . Como mostra a Figura 2, em 11 dias de armazenamento é possível visualizar a presença de bolores e leveduras no tratamento PVC.

Figura 2 - Aspecto visual dos morangos em 11 dias de armazenamento (Esquerda para direita: PVC, FCC e

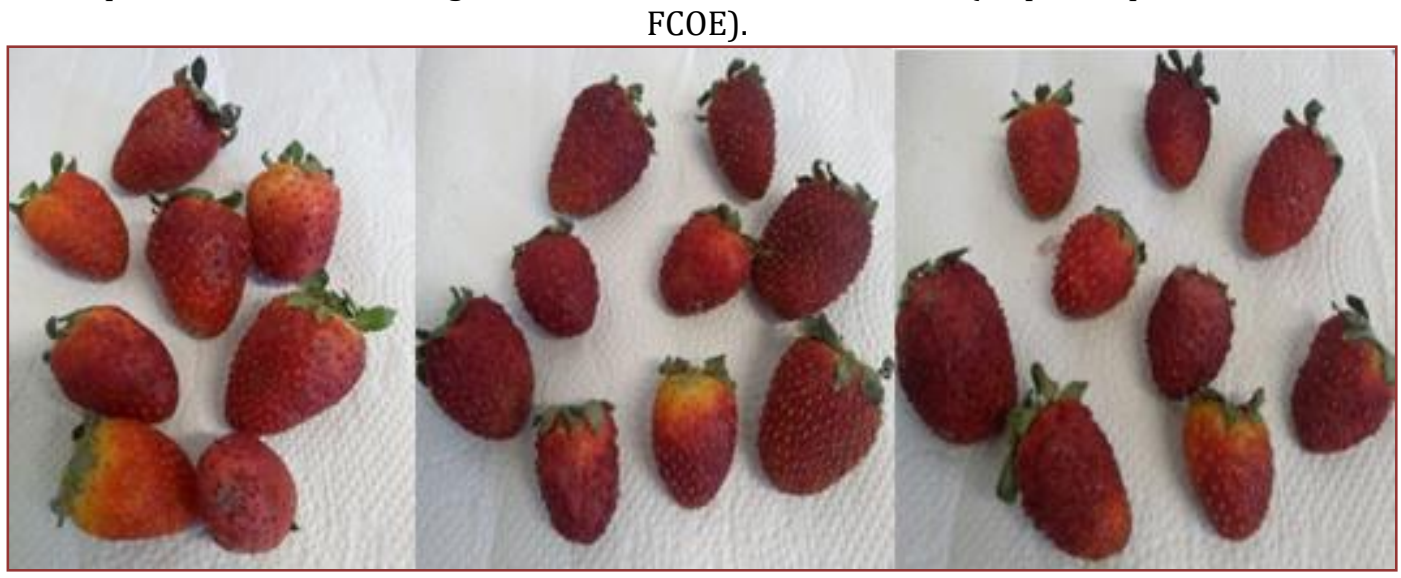

Fonte: Autor. 
Tabela 2 - Contagem de bolores e leveduras (log UFC/g) de morangos armazenados sob refrigeração $\left(5^{\circ} \mathrm{C}\right)$ com diferentes filmes, PVC, FCC E FCOE.

\begin{tabular}{|c|c|c|c|c|}
\hline \multirow{2}{*}{ Filme } & \multicolumn{4}{|c|}{ Dias de armazenamento } \\
\hline & & 4 & 7 & \\
\hline PVC & $2,60^{\mathrm{aB}} \pm 0,02$ & $3,76^{\mathrm{aA}} \pm 0,18$ & $3,30^{\mathrm{aAB}} \pm 0,10$ & $3,80^{\mathrm{aA}} \pm 0,90$ \\
\hline FCC & $2,60^{\mathrm{aB}} \pm 0,02$ & $3,19 \mathrm{aAB} \pm 0,31$ & $3,29 \mathrm{aA} \pm 0,28$ & $2,87 \mathrm{aAB} \pm 0,15$ \\
\hline FCOE & $2,60^{\mathrm{aB}} \pm 0,02$ & $3,52^{\mathrm{aA}} \pm 0,27$ & $3,10^{\mathrm{aA}} \pm 0,09$ & $2,20^{\mathrm{aB}} \pm 0,03$ \\
\hline
\end{tabular}

Letras minúsculas diferentes nas colunas diferem significativamente $(\mathrm{p}<0,05)$; Letras maiúsculas diferentes nas linhas diferem significativamente $(\mathrm{p}<0,05)$.

PVC: Policloreto de vinila; FCC: Fibra de colágeno controle; FCOE: Fibra de colágeno com adição de 1\% de óleo essencial de Pimenta Rosa.

Chu et al. (2020), encontraram contagens de bolores e leveduras para os morangos revestidos de filme biodegradável (pullulan) no quarto dia maiores (3,344 log UFC/g) que das encontradas neste estudo para o filme FCC (3,19 log UFC/g) também no dia quatro de armazenamento. E no sexto dia, os autores também encontraram valores maiores (4,657 log UFC/g) do que no presente estudo foi encontrado para os dias sete e onze de armazenamento para todos os filmes. Trabalho de Shahbazi (2018), a contagem de bolores e leveduras em filmes de quitosana e carboximetilcelulose no último dia de armazenamento ( $12^{\circ}$ dia) foi de 3,75 log UFC/g, valor acima do encontrado para os filmes de FCC e FCOE.

\section{CONCLUSÕES}

Os morangos embalados com a FCOE apresentaram maior teor de umidade em relação ao FCC em 4 dias de armazenamento. Em relação a contagem de bolores e leveduras, não foram observadas diferenças significativas entre os filmes produzidos a base de fibra de colágeno e o polímero sintético durante os dias de armazenamento, o que demonstra a potencialidade dos filmes a base de fibra de colágeno. Durante o período de armazenamento a contagem de bolores e leveduras dos morangos embalados com PVC aumentou significativamente do dia 0 em relação ao dia 11, diferente dos filmes de FCC e FCOE que na contagem do dia 11 não apresentaram diferenças significativas da contagem do dia 0 , assim, os filmes produzidos apresentam uma ação frente ao crescimento de bolores e leveduras em morangos.

\section{REFERÊNCIAS}

[1] Cagri, A., Ustunol, Z., Ryser, E. T. (2004). Antimicribial edible films and coatings. Journal of Foof Protection, 67 (4), 833-848.

[2] Chu, Y., Gao, C. C., Liu, X., Zhang, N., Xu, T., Feng, X., Yang, Y., Shen, X., Tang, X. (2020). Improvement of storage quality of strawberries by pullulan coatings incorporated with cinnamon essential oil nanoemulsion. LWT, 122, 109054.

[3] Dannenberg, G. S., Funck, G. D., Silva, W. P., Fiorentini, A. M. (2019). Essential oil from pink pepper (Schinus terebinthifolius Raddi): Chemical composition, antibacterial activity and mechanism of action. Food Control, 95, 115120.

[4] Dong, F., Wang, X. (2017). Effects of carboxymethyl cellulose incorporated with garlic essential oil composite coatings for improving quality of strawberries. International Journal of Biological Macromolecules, 104, 821-826.

[5] Garcia, M. A., Martino, M. N., Zaritzy, N. E. (1998). Plasticized starch-based coatings to improve strawberry (Fragaria ananassa) quality and stability. Journal of Agricultural and Food Chemistry, 46, 3758-3767.

[6] Gitz, V., Prakash, V., Ambuko, J., Belik, W., Huang, J., Timmemans, A. (2014). Food Losses and Waste in the Context of Sustainable Food System, 387-388.

[7] Instituto Adolfo Lutz (São Paulo). (2008). Métodos físico-químicos para análise de alimentos. São Paulo: Instituto Adolfo Lutz.

[8] Kilcast, D., Subramaniam, P. (2000). The Stability and Shelf-Life of Food. CRC PRESS, Taylor and Francis Group: Cambridge England.

[9] Paglione, I. S., Galindo, M. V., Medeiros, J. A. S., Yamashita, F., Alvim, I. D., Grosso, C. R. F., Sakanaka, L. S., Shirai, M. A. (2019). Comparative study of the properties of soy protein concentrate films containing free and encapsulated oregano essential oil. Food Packaging and Shelf Life, 22, 100419.

[10] Perdones, A., Sánchez-González, L., Chiralt, A., Vargas, M. (2012). Effect of chitosan-lemon essential oil coatings on storage-keeping quality of strawberry. Postharvest Biology and Technology, 70, 32-41. 
[11] Shahbazi, Y. (2018). Application of carboxymethyl cellulose and chitosan coatings containing Mentha spicata essential oil in fresh strawberries. International Journal of Biological Macromolecules, 112, 264-272.

[12] Silva, N., Junqueira, V. C. A., Silveira, N.F.A. (2001). Manual de métodos de análise microbiológica de alimentos. 2.ed. São Paulo: Livraria Varela, 317p.

[13] Tanada-Palmu, P. S., Grosso, C. R. F. (2005). Effect of edible wheat gluten-based films and coatings on refrigerated strawberry (Fragaria ananassa) quality. Postharvest Biology and Technology, 36(2), 199-208.

[14] Velickova, E., Winkelhausen, E., Kuzmanova, S., Alves, V. D., Moldão-Martins, M. (2013). Impact of chitosanbeeswax edible coatings on the quality of fresh strawberries (Fragaria ananassa cv Camarosa) under commercial storage conditions. LWT - Food Science and Technology, 52 (2), 80-92.

[15] Yamashita, F., Veiga, G. F., Benassi, M. T., Roberto, S. R. (2006). Morangos embalados com filme de Policloreto de vinila (PVC). Semina: Ciências Agrárias, 27 (3), 429-436.

[16] Xu, J., Liu, F., Goff, D., Zhong, F. (2019). Effect of pre-treatment temperatures on the film-forming properties of collagen fiber dispersions. Food Hydrocolloids, 105326.

[17] Wolf, K. L., Sobral, P. J. A., Telis, V. R. N. (2009). Physicochemical characterization of collagen fibers and collagen powder for self-composite film production. Food Hydrocolloids, 23 (7), 1886-1894. 


\section{Capítulo 17}

\section{Análise colorimétrica de pão com adição de farinha de bagaço de azeitona}

\section{Juliana Silveira de Quadros \\ Jeff Oliveira Soares \\ Mariane Garcia Orqis Barcellos \\ João Tomaz Silva Barcellos Júnior \\ Miriane Lucas Azevedo \\ Fernanda Germano Alves Gautério}

Resumo: 0 processamento de azeite de oliva possui resíduos gerados e preocupa-se seu descarte inadequado, entretanto devido a apresentar uma alta carga de compostos bioativos e nutrientes, vem ganhando destaque na indústria alimentícia. Com isso, surge o desenvolvimento de novos produtos alimentícios como proposta. 0 objetivo deste trabalho foi analisar colorimetricamente o pão desenvolvido com adição de farinha de bagaço de azeitona. . O bagaço de azeitona foi obtido da safra de 2019 da Região da Campanha. Foi desenvolvido formulações de pão com adição de FBA e pão controle. A seguir, utilizou-se o Colorímetro Minolta com medição da luminosidade ( $L^{*}$ ) e das coordenadas de cromaticidade $\mathrm{a}^{*} \mathrm{e} \mathrm{b}^{*}$ para posterior cálculo do ângulo de tonalidade (Hue, $\mathrm{H}^{\circ}$ ) e croma $\left(\mathrm{C}^{*}\right)$. Os resultados obtidos foram valores menores para a FBA em todas as propostas de análise. Já o pão com adição de FBA obteve os maiores resultados nas coordenadas de cromaticidade e de croma. Assim, foi possível observar as transformações bioquímicas presentes nas operações de panificação e analisar a importância da utilização do coproduto da olivicultura no desenvolvimento de novos produtos.

Palavras-Chave: colorimetria; coproduto; olivicultura; desenvolvimento de produto. 


\section{INTRODUÇÃO}

Utilizando da análise colorimetrica de alimentos é possível avaliar a aceitabilidade mercadológica e a qualidade do produto. Assim, é possível prever se o produto será atraente para o consumidor. A cor é o primeiro aspecto utilizado na aceitação ou rejeição, devido a ser o primeiro contato do consumidor com o produto; podendo julgar através de conceitos pré-formados se o produto é de qualidade ou não. Na análise desse fator devem ser consideradas três parâmetros: o tom, comprimento de onda da luz refletida pelo objeto; a intensidade, definida pela concentração de substâncias corantes dentro do alimento; e o brilho, que é a quantidade da luz refletida pelo corpo em comparação com a quantidade de luz que incide sobre o mesmo (TEIXEIRA, 2009). A coloração do produto é pensado pela área de desenvolvimento de novos produtos, onde é pensado e analisado o que é atrativo ao consumidor.

A área de novos produtos é um processo complexo e multidisciplinar, que tem como função a sobrevivência das empresas e atender as necessidades dos consumidores. As empresas, principalmente de alimentos, necessitam lançar produtos novos com frequência para se manterem à frente da concorrência. Assim como, os consumidores que estão cada vez mais em busca por novidades diminuíram sua fidelidade às marcas, tornando o mercado de alimentos muito mais competitivo e encurtando o ciclo de vida dos produtos lançados (WILLE, 2004). Através dos meios de comunicação é divulgado uma relação entre alimentação e saúde gerando uma preocupação da sociedade pela busca de qualidade de vida. Com isso, ocorre a explosão do mercado de alimentos saudáveis, como os alimentos funcionais que proporcionam benefícios para a saúde, através de nutrientes e compostos bioativos, levando à prevenção e o tratamento de doenças (ANJO, 2004).

A gestão dos resíduos nas indústrias de extração de azeite é preocupante pela elevada carga poluente e a toxicidade que estes possuem, além do seu descarte inadequado. Deste processamento são resultantes resíduos como as águas residuais, o bagaço de azeitona que, inclui a polpa, pele, caroço e folhas de oliveira. Sabe-se que destes resíduos, o bagaço de azeitona é rico em açúcares, compostos nitrogenados, ácidos voláteis, poliálcoois, pectinas, gorduras e polifenóis e, por isso, tem sido objeto de pesquisa visando a sua utilização para fins alimentícios, como o desenvolvimento de novos produtos (BRITO, 2016; DUARTE, 2011; OLIVEIRA, 2018).

Assim, visando a diminuição dos impactos ambientais, bem como, o desenvolvimento de um novo produto, o presente trabalho teve como objetivo a análise colorimétrica de um pão desenvolvido com adição de farinha de bagaço de azeitona.

\section{MATERIAL E MÉTODOS}

O bagaço de azeitona foi proveniente da safra de 2019 da Região da Campanha do Rio Grande do Sul, foi mantido congelado a $-18^{\circ} \mathrm{C}$, por uma semana, para posterior transformação em farinha. Para a obtenção da farinha de bagaço de azeitona (FB(A), o bagaço foi submetido à operação de secagem, peneiramento e moagem.

Com a farinha de bagaço de azeitona já pronta foi possível o desenvolvimento das formulações de pão. Foi realizada uma formulação de um pão controle (isento de farinha de bagaço de azeitona) para posterior comparação. Para a produção do pão controle (PC) foram utilizados os seguintes insumos: farinha de trigo, fermento biológico seco, sal, açúcar e leite integral. Já para o pão com adição da farinha de bagaço de azeitona elaborou-se uma nova formulação de pão na proporção de 1:1, entre farinha de trigo e farinha de bagaço de azeitona, mantendo os demais insumos. Na elaboração do pão procedeu-se a pesagem e homogeneização dos insumos e modelagem da massa obtida, seguida da operação de forneamento a $150^{\circ} \mathrm{C}$ por 50 minutos em forno elétrico.

Posteriormente, foi empregada a análise colorimétrica nas seguintes amostras (Figura 1): bagaço, farinha de bagaço e na parte interna dos pães (controle e adicionado da farinha de bagaço de azeitona). 
Figura 1 - Amostras analisadas
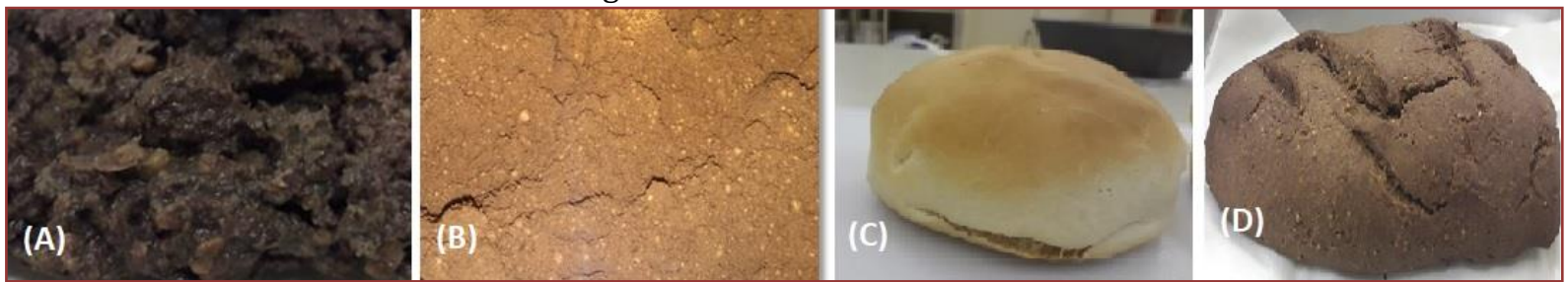

A: Bagaço de azeitona in natura; B: Farinha de bagaço de azeitona; C: Pão controle; D: Pão com adição de FBA Fonte: Autores, 2020

A análise de cor instrumental foi realizada, em triplicata, em Colorímetro Minolta com determinação das coordenadas de cromaticidade $\mathrm{a}^{*} \mathrm{e} \mathrm{b}^{*}$ e luminosidade $\mathrm{L}^{*}$ para posterior cálculo do ângulo de tonalidade (Hue, $H^{o}$ ) e croma $\left(\mathrm{C}^{*}\right)$, conforme as equações 1 e 2 , respectivamente.

$$
\begin{aligned}
& \text { Hue } *=\tan ^{-1}\left(\frac{b *}{a *}\right) \\
& C *=(a *)^{2}+(b *)^{2}
\end{aligned}
$$

\section{RESULTADOS E DISCUSSÃO}

Os resultados obtidos de croma $\left(\mathrm{C}^{*}\right)$, ângulo de Tonalidade $\left(\mathrm{H}^{\circ}\right)$ e as coordenadas de cromaticidade $\left(\mathrm{a}^{*} \mathrm{e}\right.$ $\mathrm{b}^{*}$ ) e luminosidade ( $\mathrm{L}^{*}$ ), para o bagaço in natura, FBA, PC e Pão 1:1 estão apresentados na Tabela 1. Para todas as amostras os valores das coordenadas de cromaticidade foram positivos, ou seja, $\mathrm{a}^{*} \mathrm{e}$ *b tendendo, respectivamente, para vermelho e amarelo. A mudança de coloração (croma $\mathrm{C}^{*}$ ) ocorreu durante o processo de moagem ocasionando à exposição dos carotenoides presentes no bagaço de azeitona, em especial devido à presença da luteína e $\beta$-caroteno, sendo consequência da degradação da clorofila indicando a presença e os efeitos das enzimas degradadoras destes pigmentos, como as lipoxigenases e peroxidases (UENOJO, 2007).

\begin{tabular}{|c|c|c|c|c|c|}
\hline Amostras & $a^{*}$ & $\mathrm{~b}^{*}$ & Croma (C*) & Hue $\left({ }^{\circ} \mathrm{H}\right)$ & Luminosidade (L*) \\
\hline BA & $1,11 \pm 0,05$ & $4,93 \pm 0,53$ & $5,05 \pm 0,51$ & $77,27 \pm 0,61$ & $22,46 \pm 0,85$ \\
\hline FBA & $0,45 \pm 0,267$ & $0,10 \pm 0,69$ & $0,46 \pm 0,27$ & $13,37 \pm 0,69$ & $15,53 \pm 0,04$ \\
\hline $\mathrm{PC}$ & $6,33 \pm 0,54$ & $24,89 \pm 1,1$ & $25,68 \pm 1,9$ & $75,73 \pm 0,16$ & $50,40 \pm 0,55$ \\
\hline P1:1 & $24,04 \pm 2,15$ & $20,52 \pm 0,31$ & $31,61 \pm 1,36$ & $45,68 \pm 2,60$ & $12,01 \pm 1,25$ \\
\hline
\end{tabular}

Tabela 1- Análise colorimétrica instrumental das amostras

BA: Bagaço de azeitona in natura; FBA: Farinha de bagaço de azeitona; P1:1 (Farinha trigo: FBA); PC: Pão controle; a* e b*: coordenadas cromáticas. Média \pm desvio padrão.

Fonte: Autores, 2020.

A FBA apresentou valores de $L^{*}(15,53), a^{*}(0,45)$ e $b^{*}(0,10)$, caracterizando uma baixa luminosidade, em ocorrência à exposição dos carotenóides mediante a operação de moagem. Já na análise cromática, FBA apresentou uma menor intensidade de cor $\mathrm{C}^{*}(0,46)$, dentre os produtos analisados, em virtude da menor atividade de água desta promovida pelo processo de liofilização, o qual ocasionou uma maior concentração dos compostos (GARCIA, 2009). Para o PC se tem um maior valor de $L^{*}(50,40)$ em consequência de uma maior presença de açúcares, promovido pela conversão do amido do trigo (SCHEUER, 2011), sendo diretamente ligado à coloração dos pães (EL-DASH, CAMARGO E DIAZ, 1982).

Na análise de cromaticidade o pão $1: 1$ tendeu a uma coloração mais escura $L^{*}(12,01)$ e uma menor intensidade de cor ao produto $C^{*}(25,68)$, devido à degradação das clorofilas durante a moagem da amostra, expondo, dessa forma, os pigmentos do bagaço. Já o PC caracterizou uma maior reflectância à luz e uma maior intensidade de cor com valor de croma $C^{*}(31,61)$, como esperado, devido à coloração clara do pão proveniente da reação de Maillard e/ou caramelização (ESTELLER; AMARAL; LANNES, 2004; MATOS; SANZ; ROSELL, 2014) durante o processo térmico de forneamento dos pães. 
$\mathrm{O}$ ângulo de tonalidade $\left({ }^{\circ} \mathrm{H}\right)$, quando próximo de $0^{\circ}$ tende à coloração mais avermelhada, variando para o amarelo até o ângulo de 90․ Na presente pesquisa, todas as amostras se encontram nessa faixa. O PC tendeu à coloração mais amarelada devido à cor característica do miolo, enquanto o pão 1:1 apresentou uma coloração mais avermelhada, em consequência da presença de FBA, ocasionando uma maior intensidade $*$ C ao produto.

\section{CONCLUSÕES}

De acordo com os resultados obtidos da análise colorimétrica instrumental observou-se as alterações de cor na formulação do pão com FBA em comparação ao pão controle Ademais, foi possível constatar as transformações bioquímicas presentes nas operações de panificação, além de analisar a importância da utilização do coproduto da olivicultura em âmbito sustentável e de sua aplicabilidade no desenvolvimento de novos produtos.

\section{AGRADECIMENTOS}

Agradecimento ao Programa de Desenvolvimento Acadêmico (PDA) da Universidade Federal do Pampa e à Fundação de Amparo à Pesquisa do Estado do Rio Grande do Sul (FAPERGS) e ao Conselho Nacional de Desenvolvimento Cientifico e Tecnológico (CNPq) pela concessão das bolsas.

\section{REFERÊNCIAS}

[1] ANJO, D. F.C. Alimentos funcionais em angiologia e cirurgia vascular. Jornal Vascular Brasileiro, v. 3, n. 2, p. $145-154,2020$.

[2] BRITO, R. F. Valorização integrada de resíduos e subprodutos da extração do azeite: extração e caracterização de compostos bioativos do bagaço de azeitona. 2016. (Dissertação de Mestrado em Tecnologia de Alimentos) - Instituto Superior de Engenharia, Universidade do Algarve, Faro, 2016.

[3] DUARTE, C.S.C. Extração e encapsulamento de compostos bioativos do bagaço de azeitona. 2011. (Dissertação de Mestrado em Engenharia Alimentar) - Instituto Superior de Agronomia, Universidade Técnica de Lisboa. Lisboa, 2011.

[4] EL-DASH, A.A.; CAMARGO, C.E.; DIAZ, N. M. Fundamentos da Tecnologia de Panificação. São Paulo: Coordenadoria da Indústria e Comércio, 1986.

[5] ESTELLER, M. S.; AMARAL, R. L.; LANNES, S. C. S. Effect of sugar and fat replacers and the texture of braked goods. Journal of Texture Studies, USA, v.35, n.4, p.383-393, 2004.

[6] GARCIA, L. P. Liofilização aplicada a alimentos. 2009. 45p. Trabalho Acadêmico (Graduação Bacharelado em Química de Alimentos) - Universidade Federal de Pelotas. Pelotas, RS, 2009.

[7] MATOS, M. E.; SANZ, T.; ROSELL, C. M. Establishing the function of proteins on the rheological and quality properties of rice based gluten free muffins. Food Hydrocolloids, v. 35, p. 150-158, 2014

[8] OLIVEIRA, E.S.F. Adição de farinha de bagaço de azeitona em bolos com goma xantana isentos de glúten. Anais do Salão Internacional de Ensino, Pesquisa e Extensão, v. 9, n. 5, 2018.

[9] SCHEUER, P. M. FRANCISCO, A; MIRANDA, M. Z; LIMBERGER, V.M. Trigo: características e utilização na panificação. Revista Brasileira de Produtos Agroindustriais. Campinas grande, v.13, n.2, p.211-222. 2011.

[10] TEIXEIRA, L.V. Análise sensorial na indústria de alimentos. Revista do Instituto de Laticínios Cândido Tostes, v. 64, n. 366 , p. 12-21, 2009.

[11] UENOJO, M.; MARÓSTICA-JUNIOR, M.R.; PASTORE, G.M. Carotenóides: propriedades, aplicações e biotransformação para formação de compostos de aroma. Química Nova, v. 30, n. 3, p. 616-622, 2007.

[12] WILLE, G. M. F. C. et al. Práticas de desenvolvimento de novos produtos alimentícios na indústria paranaense. Revista da FAE, v. 7, n. 2, 2004. 


\section{Capítulo 18}

\section{Cookies integrais com farinha de baru e jatobá}

\section{Júlia Nascimento Caldas}

\section{Fabrícia Queiroz, Mendes}

Resumo: No estado de Minas Gerais, a exploração agrícola do Alto Paranaíba teve intenso desencadeamento com o Padap - projeto de ocupação do território. Como todo processo intensivo de uso agrícola, houve uma redução fauna e flora regional, alterando também a cultura da alimentação, diminuindo o consumo de produtos regionais. Acréscimo dos frutos do cerrado, antigamente consumidos, buscando enriquecimento nutricional de preparações atualmente consumidas como cookies, que vem ganhando espaço no mercado, seria alternativa para produtos que abraçassem as novas necessidades dos consumidores e resgate da cultura alimentar regional. Objetivou-se o desenvolvimento de um cookie integral com farinha de baru e jatobá. 0 produto desenvolvido contém teor de proteínas maiores que produtos semelhantes e pode ser rotulado como fonte de fibra. São uma boa forma de incrementar os frutos na alimentação regional, aumentando teor de fibras na alimentação e resgatando o sabor característico, posteriormente será realizado análises sensoriais pelos possíveis consumidores.

Palavras-Chave: Cookie; Cerrado; Jatobá-do-Cerrado; Baru. 


\section{INTRODUÇÃO}

O cerrado mineiro sofreu grande interferência de programas de ocupação e expansão do território nacional, como o Padap (Programa de Assentamento Dirigido do Alto Paranaíba), que ocasionaram na ocupação da região do Alto Paranaíba, contemplando as cidades de Campos Altos, Ibiá, Rio Paranaíba e São Gotardo. Esse e outros projetos promovendo a agricultura e industrialização das áreas ocupadas, visavam explorar a terra de acordo com o que fora fomentado em pesquisas oriundas da "Revolução Verde". Mesmo com fatores legais prescritos anteriormente que idealizavam a preservação da vegetação nativa, proveram grandes desmatamentos e perdas ecológicas, da fauna e da flora regional, consequentemente, mudando os hábitos culturais do espaço.

O desconhecimento da flora nativa pelas novas gerações, decorrente das modificações do espaço, levou a perda dos hábitos de cultivo, consumo e utilização das mesmas. Os frutos nativos do bioma apresentam características sensorias atrativas como suas cores, aromas e sabores, muito apreciadas para a preparação de licores, geleias e doces, produtos de apelo cultural onde suas receitas são passadas por gerações.

Com nomes populares de barujo, cumaru, cumbaru, cumarurana, coco-feijão, baru nuts ou apenas baru, é o fruto do barueiro, uma árvore semiducídua de copa globulosa e densa capaz de alcançar entre $15-25 \mathrm{~m}$ de altura e 40-70 cm de diâmetro. Os frutos são drupas, oblongo-achatados e de coloração marrom, com uma única semente drupácea, revestida por endocarpo de difícil remoção, bastante apreciada utilizada na alimentação humana e de gados enquanto pastam (BOTEZELLI et al., 2000; VERA et al., 2009; KINUPP E LORENZI, 2014). A região do Centro-Oeste brasileiro faz uso constante do fruto, visto que sua polpa é aproveitada para a elaboração de licores, geleias ou consumo in natura. As sementes podem servir como matéria prima para a elaboração de farinhas e com isso subprotudos quando consumidas torradas com sal, processos que podem ser realizados de forma caseira para consumo próprio. É possível também a retirada do óleo da amêndoa (KINUPP E LORENZI, 2014).

Popularmente denominado por Jatobá-do-Cerrado, jataí ou jutaí, o Hymenaea stigonocarpa é uma vagem, da família Fabaceae-Caesalpinioideae, bem como Hymenaea courbaril L, Jatobá-da-Mata, são facilmente encontrados nas regiões, como cerrado e caatinga, de clima tropical pelo crescimento espontaneo. Plantas arbóreas, com a casca dos frutos de coloração marrom e interior com a polpa farinhosa variando entre o verde e o amarelado sendo sua semente de coloração semelhante a casca (SANTANA et al., 2016; SILVA, 2019). Ecologicamente apresenta potencial para cultivo em áreas de preservação, a fim de arborização incluindo reconstrução de áreas desmatadas, para pomares domésticos e em áreas montanhosas (SILVA et al., 2014), sua árvore também pode ser explorada para construção civil (Faria et al., 2013).

Falta de tempo, investimentos em maquinários e praticidade são características de uma vida moderna e globalizada que nos instiga a procurar sempre a novidade e deixar de lado o comum. Mesmo com tantas informações e agilidades proporcionadas pelo novo estilo de vida, convivemos também com o movimento contrário de resgate que difunde a ideia de conciliação da vida tecnológica com a natureza. A escolha dos consumidores se dá por produtos que apresentem novidades tecnológicas ecologicamente corretas e ao mesmo tempo enxerguem e atenda as demandas dos novos mercados.

Como é ressaltado por ABRAHAM et al., (2018) fast foods são alimentos com elevado valor de triglicerídeos e seu consumo elevado pode estar associado a doenças no trato gastrointestinal (TGI), como inflamações e irritações, oriundas da alta ingestão de proteínas da carne, açúcares conjuntamente bem como a baixa ingestão de fibras, em indivíduos sadios.

Desde os anos 2000, já haviam preocupações com a interferência de fast foods nos hábitos alimentares e saúde dos consumidores. Desde então são realizados estudos em diversos países, mas em maioria nos Estados Unidos da América, que comprovam a influência da nova cultura para o aumento do número de obesos, independente da faixa de renda (BINKLEY et al., 2000; PATEL et al., 2018).

Como relatado por SILVA et al. (1998) e FASOLIN et al. (2007) o biscoito tipo cookie é uma preparação com grande aceitação, vida de prateleira mais prolongada e bastante consumida, qual vem sendo estudada, buscando seu enriquecimento nutricional. Mesmo que o consumo nacional de massas em geral no ano de 2018, tenha diminuído quando comparado a 2017, o tipo cookies teve aumento de vendas, que a retomada do poder aquisitivos da população nacional, os produtos como cookies, wafers e cobertos retomem os destaques e a competitividade com os tradicionais.

Desta forma, o presente trabalho busca utilizar baru e o jatobá para a elaboração de cookies, visando a busca por sabores regionais e o incremento de fibras na alimentação. 


\section{MATERIAIS E MÉTODOS}

Os cookies foram elaborados a partir de uma formulação com farinha de trigo integral $(240 \mathrm{~g})$ açúcar mascavo (125g), ovos (2 unidades), manteiga (100g), cacau em pó (45g), fermento $(2 \mathrm{~g})$, sal $(2 \mathrm{~g})$ e bicarbonato (2g), onde a farinha de trigo foi diminuída entre $40-30 \%$ dependendo do sabor formulado, por uma mistura das farinhas de jatobá e baru. Os frutos de jatobá foram coletados em propriedades da região do Alto Paranaíba, a farinha de baru foi adquirida em distribuidores especializados em frutos do cerrado, enquanto os demais ingredientes para a elaboração foram obtidos em mercado da região.

A massa padrão crua apresenta cerca de $585 \mathrm{~g}$, e a partir dela foram formuladas as versões tradicional, sem o incremento de aditivos e com cacau em pó e com essência de baunilha. Em unidade com peso médio de $15 \mathrm{~g}$, os cookies foram analisados quanto cinzas, umidade, lipídios, proteínas e fibras, pelos métodos de Adolfo Lutz, em triplicata, e comparados com dados dos ingredientes indivualmente em literaturas como a Tabela Brasileira de Composição de Alimentos, artigos das farinhas de baru e jatobá apresentado nesse artigo e Tabela de Composição de Alimentos: Suporte Para Decisão Nutricional. Os cookies protos foram comparados com produtos comercializados de mesmo propósito quanto ao preço e atributos. As porcentagens da formulação podem ser observadas na Tabela 1.

Tabela 1 - Formulação dos cookies

\begin{tabular}{|c|c|c|c|c|c|c|}
\hline & \multicolumn{2}{|c|}{ Tradicional } & \multicolumn{2}{|c|}{ Cacau } & \multicolumn{2}{|c|}{ Baunilha } \\
\hline & (g) & $\%$ & (g) & $\%$ & (g) & $\%$ \\
\hline Açúcar Mascavo & 125 & 24,70 & 125 & 24,82 & 125 & 24,61 \\
\hline Ovos & 100 & 19,76 & 100 & 19,86 & 100 & 19,69 \\
\hline Farinha de Baru & 80 & 15,81 & 75 & 14,89 & 80 & 15,75 \\
\hline Farinha de trigo integral & 80 & 15,81 & 75 & 14,89 & 80 & 15,75 \\
\hline Manteiga & 75 & 14,82 & 75 & 14,89 & 75 & 14,76 \\
\hline Farinha de Jatobá & 40 & 7,91 & 35 & 6,95 & 40 & 7,87 \\
\hline Cacau & - & - & 12,6 & 2,50 & - & - \\
\hline Sal & 2 & 0,40 & 2 & 0,40 & 2 & 0,39 \\
\hline Fermento & 2 & 0,40 & 2 & 0,40 & 2 & 0,39 \\
\hline Bicarbonato & 2 & 0,40 & 2 & 0,40 & 2 & 0,39 \\
\hline Essência de Baunilha & - & - & - & - & 2 & 0,39 \\
\hline
\end{tabular}

Fonte: Próprio autor

\section{RESULTADOS E DISCUSSÃO}

Após analisados, os cookies tiveram resultados de umidade média de $10 \%$. A tabela nutricional para os cookies tradicionais e de baunilha e para os cookies com adição de cacau está exposta na Tabelas 2 .

Comparando com produtos similares, podemos encontrar produtos que sejam com castanhas (castanhado-Pará ou castanha-do-caju) ou gotas de chocolate. Também há produtos com grãos como linhaça, quinoa, gergelim a e aveia, ofertadas formulações com ou sem glúten e/ou lactose. De uma forma geral suas porções variam entre 20-40g (entre 2 e 8 biscoitos), enquanto seus valores nutricionais médios são: carboidrato $11-20 \mathrm{~g}$, proteínas 1,0-2,8g, gorduras totais $3-10 \mathrm{~g}$, fibra alimentar 1,1-2,6g sendo que uma marca apresentou 5,6g e sódio médio entre 26-168mg. Levando em consideração os atributos de cada um dos ingredientes utilizados, pôde-se estimar que o produto final que apresentou, quando comparado a outros semelhantes no mercado, percentuais de proteína e fibra elevados podendo assim ser caracterizado como "fonte de fibras" (BRASIL, 2012). 
Tabela 2 - Tabela nutricional dos cookies tradicionais e com adição de essência de baunilha e cookies com adição de cacau

\begin{tabular}{|l|c|c|} 
& \multicolumn{2}{|c|}{$\begin{array}{c}\text { Porção de 45g (3uni) } \\
\text { Cookies tradicionais e de baunilha }\end{array}$} \\
\hline Valor Energético (kcal) & 166,94 & 166,44 \\
\hline Carboidratos (g) & 20,74 & 20,96 \\
\hline Proteínas (g) & 11,14 & 11,02 \\
\hline Gordura (g) & 4,38 & 4,28 \\
\hline Gordura Saturados (g) & 0,92 & 0,9 \\
\hline Gordura Trans (g) & 0 & 0 \\
\hline Fibras Alimentares (g) & 4,8 & 4,1 \\
\hline Sódio (mg) & 112 & 112 \\
\hline
\end{tabular}

Fonte: Próprio autor

0 jatobá-do-cerrado possui níveis altos de fibras alimentares (44,3\%), sendo 17,1\% de celulose, possui $5,6 \%$ de proteína e fornece 193kcal de energia por $100 \mathrm{~g}$ (CARDOSO et al., 2013). Possui $12 \%$ de umidade e $5 \%$ de cinzas. No jatobá-do-cerrado foi encontrado baixo teor de vitamina $\mathrm{C}$ e carotenoides $(8,9 \mathrm{mg} / 100 \mathrm{~g}$ e $0,4 \mathrm{mg} / 100 \mathrm{~g}$ respectivamente), além de vitamina $\mathrm{E}$ (53,5 $\mathrm{mg} / 100 \mathrm{~g}$ ) e fosfato (495,5 $\mathrm{mg} / 100 \mathrm{~g})$. Alguns estudos apontaram que o fruto tenha teores de fenólicos totais $34,1 \mathrm{mg} / 100 \mathrm{~g}$, antocianinas $0,88 \mathrm{mg} / 100 \mathrm{~g}$, flavonoides $19,64 \mathrm{mg} / 100 \mathrm{~g}$, licopeno 9,96 mg/100g (MATUDA e MARIA NETTO, 2005; CARDOSO et al. 2013; ROCHA et al., 2013). Estudos apontaram o consumo popular de suas cascas e polpa como laxante, antiinflamatório, dentre outras (SOUZA E FELFILI, 2006; CARVALHO, 2007), enquanto outros registraram efeitos como a redução dos níveis de glicemia, colesterol, ação antimutagênica (SANTANA et al., 2016) tornando um ingrediente muito promissor a alimentos com alto teor de carboidratos simples e lipídios.

A castanha de baru tem um sabor mais suave, parecido ao do amendoim, apresenta elevado teor proteico (entre 25-30\%), e lipídico (40\%) sendo em maior quantidade ácidos oleico, o linoleico e palmítico, descritos em ordem decrescentemente (VERA et al.; FERNANDES et al., 2010; BORGES et al., 2014). Estudos apontam as castanhas do fruto de baru tem potencial antioxidante devido aos seus compostos fenólicos (BORGES et al., 2014). SIQUEIRA et al., (2012) observou que, além dos compostos fenólicos, os ácidos fíticos também agiram como antioxidante em ratos sujeitos a uma alimentação com suplementação de ferro, sendo que o efeito do consumo das castanhas evitou o estresse causado pelo mineral.

O cookie produzido, comparado a outros produtos semelhantes do mercado, apresenta percentuais de proteína e fibra elevados podendo ser caracterizado como "fonte de fibras" (BRASIL, 2012). Enquanto mantém-se na média dos lipídios e carboidratos. Atributos que foram conquistados com a mesma faixa de preço especulada para o produto final de cookies similares no mercado. Desta forma, houve um incremento de fibras e proteínas ao produto, caracteristicamente como fonte de carboidrato, além de resgatar sabores típicos de produtos do cerrado.

\section{CONCLUSÃO}

Os cookies são uma boa forma de incrementar os frutos na alimentação regional, aumentando teor de fibras na alimentação e resgatando o sabor característico, posteriormente será realizado análises sensoriais do produto acabado por possíveis consumidores.

\section{REFERÊNCIAS}

[1] ABRAHAM, S., MARTINEZ, M., SALAS, G., JESSICA SMITH. J. College student 's perception of risk factors related to fast food consumption and their eating habits. Journal Nutr Hum Health, v. 2, n. 1, p. 18-21, 2018.

[2] ABRE. Consumidores do norte e nordeste são responsáveis por 37,5\% do consumo de biscoitos. Disponível em: http://www.abre.org.br/noticias/consumidores-do-norte-e-nordeste-sao-responsaveis-por-375-do-consumo-debiscoitos/. Acesso em: 11 out de 2019.

[3] Brasil. Ministério da Saúde. Agência Nacional de Vigilância Sanitária. Resolução - RDC no 54, de 12 de novembro de 2012. Poder Executivo, de 13 de novembro de 2012. 
[4] BINKLEY, J. K., EALES, J., JEKANOWSKI, M. (2000). The relation between dietary change and rising US obesity. International Journal of Obesity, v. 24, n. 8, p. 1032-1039. BOTEZELLI, L.; DAVIDE, A. C.; MALAVASI, M. M. CARACTERÍSTICAS DOS FRUTOS E SEMENTES DE QUATRO PROCEDÊNCIAS DE Dipteryx alata VOGEL ( BARU ). CERNE, v. 6, n. 1, p. 9-18, 2000.

[5] BORGES, T. H., RODRIGUES, N., SOUZA, A. M. PEREIRA, J. A. Effect of different extraction conditions on the antioxidant potential of baru almonds (Dipteryx alata Vog .): comparison to common nuts. Brazil. Journal of Food and Nutrition Research, v. 53, n. 2, p. 180-188, 2014.

[6] CARDoso, L. M., BEDETTI, S. F., RIBEIRO, S. M. R., ESTEVES, E. A., PINEHIRO SANT'ANA, H. M. Jatobá do cerrado' (Hymenaea stigonocarpa): chemical composition, carotenoids and vitamins in an exotic fruit from the Brazilian Savannah. Fruits, v. 68, p. 95-107, 2013.

[7] CARVALHO, P. E. R. Jatobá-do-cerrado (Hymenaea stigonocarpa): Taxonomia e nomenclatura. Circular técnico 133, EMBRAPA, Colombo-PR. p. 1-8, 2007.

[8] FARIA, T. M., SCABORA, M. H., MALTONI, K.L., CASSIOLATO, M. R. Micorrização e crescimento de progênies de hymenaea stignocarpa mart. Ex. Hayne em subsolo de área degradada. Ciência Florestal, v. 23, n. 0103- 9954, p. 233$243,2013$.

[9] FASOLIN, L. H., AMEIDA, G. C., CASTANHO, P. S., OLIVEIRA, E. R. N. Cookies produced wi th banana meal: Chemical, physical andsensorial evaluation. Ciencia e Tecnologia de Alimentos, v. 27, n. 3, p. 524-529, 2007.

[10] FERNANDES, D. C., FREITAS, J. B; CZEDER, L. P.; NAVES, M. M. V. Nutritional composition and protein value of the baru (Dipteryx alata Vog .) almond from the Brazilian Savanna. Journal Sci Food Agric, v. 90, n. March, p. 1650$1655,2010$.

[11] KINUPP, V. F.; LORENZI, H. Plantas Alimentícias Não Convencionais (PANC) no Brasil: guia de identificação, aspectos nutricionais e receitas ilustradas. 1.ed. Nova Odessa - SP: Instituto Plantarum de Estudo da Flora, 408-409p, 2014a.

[12] PATEL, O., SHAHULHAMEED, S., SHIVASHANKAR, R., TAYYAB, M., RAHMAN, A., PRABHAKARAN, D., TANDON, N., JAACKS, L. M. Association between full service and fast food restaurant density, dietary intake and overweight / obesity among adults in Delhi,. BMC Public Health, v. 18, n. 36, p. 1-11, 2018.

[13] SANTANAA, G. M., DEUSA, M. S. M., SOUZAA, J. M. C., FERREIRA, P. M. P.; FERNANDES, H. B., PERON, A. P. Antimitotic and antimutagenic action of the Hymenaea stigonocarpa bark on dividing cells. Brazilian Journal of Biology, v. 76, n. 2, p. 520-525, 2016.

[14] SILVA, A. M. Fragmentos de cerrado: espécies arbóreas de usos múltiplos para conservação do Cerrado. Tese (doutorado) - Universidade Estadual Paulista. Faculdade de Engenhatria de Ilha Solteira, 2019.

[15] SILVA, C. P., SOUSA, M. S. B., SIGUEMOTO, E. S., SOARES, R. A. M., ARÊAS, J. A. G. Chemical composition and antioxidant activity of jatobá-do-cerrado (Hymenaea stigonocarpa Martz.) flour. Food Science and Technology, v. 34, n. 3, p. 597-603, 2014.

[16] SILVA, M. R., SILVA, M. A. A. P., CHANG, Y. K. Utilização da farinha de jatobá (Hymenaea stigonocarpa Mart.) na elaboração de biscoitos tipo cookie e avaliação de aceitação por testes sensoriais afetivos univariados e multivariados. Ciência e Tecnologia de Alimentos, v. 18, n. 1, p. 25-34, 1998.

[17] SIQUEIRA, E. M. DE A., MARIN, A. M. F., CUNHA, M. S. B., FUSTINONI, A. M., SANT'ANA, L. P., ARRUDA, S. F. Consumption of baru seeds (Dipteryx alata Vog .), a Brazilian savanna nut, prevents iron-induced oxidative stress in rats. FRIN, v. 45, n. 1, p. 427-433, 2012.

[18] SOUZA, C.D. E FELFILI, J.M. Uso de plantas medicinais na região de Alto Paraíso de Goiás, GO, Brasil. Acta Bot. Bras. v. 20, n. 1, p. 135-142, 2006.

[19] VERA, R, JUNIOR, M. S. S., NAVES, R. V., SOUZA, E. R, B.; FERNANDES, E. P., CALIARI, M.; LEANDRO, M.W. Características químicas de amêndoas de barueiros (Dipteryx alata Vog .) de ocorrência natural no cerrado do estado de Goiás. Revista Bras. de Fruct. Jaboticabal, v 31, n 1, p. 112-118, 2009 


\section{Capítulo 19}

Farinha da casca de feijoa: Caracterização físicoquímica e potencial antioxidante

\section{Daiana Menin \\ Ellen Cristina Perin \\ Ellen de Souza Almeida Duarte \\ Martha Menin \\ Edimir Andrade Pereira}

Resumo: 0 processamento de frutas gera um elevado número de resíduos nas indústrias, comumente descartados, sendo que estes podem ser importantes fontes de nutrientes. Além do interesse em pesquisas e inovação na área de fruticultura, também se tem aumentado o interesse por frutas nativas brasileira, a exemplo, a feijoa (Acca sellowiana), que possui altos índices de minerais e fibras, potássio, fósforo, açúcares, cálcio, flavonoides e polifenóis entre outros. Esta pesquisa visou a elaboração e a caracterização das variáveis físicas, químicas, bioquímicas (potencial antioxidante) e microbiológica da farinha obtida a partir do despolpamento de feijoa. Os resultados obtidos foram satisfatórios, para as variáveis físicas e químicas, assim com a farinha apresentou um elevado potencial antioxidante e padrões aceitáveis pela legislação referente ao aspecto microbiológico. Assim, a farinha de feijoa se torna viável, visando o aproveitamento de resíduos e no desenvolvimento produtos.

Palavras-Chave: "goiaba-serrana"; produto de fruta; potencial antioxidante. antioxidant potential. 


\section{INTRODUÇÃO}

A feijoa, conhecida popularmente também como goiaba-serrana, goiaba-crioula ou araçá-do-rio-grande, é uma espécie de planta frutífera, a Acca sellowiana, nativa do Brasil, é adaptada a condições de clima frio, como também é largamente cultivada em países como Nova Zelândia, Estados Unidos e Colômbia (Morreto et al., 2014a). Essa fruta possui altos índices de minerais e fibras, potássio, fósforo, açúcares, cálcio, flavonoides e compostos fenólicos, além de possuir atividades anti-inflamatória, anticâncerigena e antimicrobiana (weston, 2010), sendo relevante para consumo e podendo através de processos tecnológicos adequados ser utilizada na elaboração de produtos, que resultarão em resíduos com alto valor nutritivo.

0 produto obtido das cascas de feijoa, mediante processo secagem em estufa convencional e pós moagem definiu-se como farinha da casca da feijoa (Acca sellowiana). De acordo com a Resolução CNNPA no 12 de 1978, a farinha é o produto obtido pela moagem da parte comestível de vegetais, e que pode passar por processos tecnológicos adequados. Deve ainda ser designada seguida do nome do vegetal e classificadas em simples (uma espécie) ou mista (diferentes espécies de vegetal). Assim, a farinha de fruta é definida como o produto obtido pela pulverização de frutas previamente dessecadas (Brasil, 1978).

No entanto, constantemente são gerados resíduos pelas agroindústrias e indústrias alimentícias relacionadas a elaboração de produtos de frutas, como cascas e sementes, que na maioria das vezes sem um destino rentável e adequação ambiental, levando a perda de possíveis compostos presentes em tais matrizes, enquanto poderiam ter um aproveitamento e agregação de valor na aplicação em outros produtos com boa relação custo-benefício (Chemat et al., 2012).

No caso de elaboração de farinhas de frutas, destaca-se o fato de que podem ser utilizadas em diversos produtos na forma de materiais primárias, intermediárias ou finais, como fonte enriquecedora de nutrientes, vitaminas e demais propriedades da matéria-prima, bem como na para substituição parcial da farinha de trigo (Zanatta et al, 2010). É importante considerar também que o modo de produção das farinhas também deve ser analisado, para que haja a menor perda possível das propriedades da fruta e ou subproduto desta. Um dos processos comerciais mais utilizados é o método de secagem, pois reduz o teor de umidade do produto, evitando assim reações químicas deteriorantes e desenvolvimento de microrganismos, além de evitar a perca das propriedades biológicas e nutritivas e qualidade do produto, quando feito de maneira monitorada e uniforme (Madamba, 2007).

Nesse sentido, esse estudo teve por objetivo caracterizar as propriedades físico-químicas e potencial antioxidante de farinha de casca de feijoa, visando futuras aplicações em produtos alimentícios e aproveitamento de tal resíduo.

\section{MATERIAL E MÉTODOS}

\subsection{MATERIAL}

O estudo ocorreu nos laboratórios de química da Universidade Tecnológica Federal do Paraná, campus Pato Branco (UTFPR/PB). Frutos de feijoa (Acca sellowiana), cultivar Alcântara, foram adquiridas em abril de 2019, no município de Água Doce - SC, Brasil, em pomar experimental particular (latitude 26² $52^{\prime} 15.6^{\prime \prime}$ S, longitude $51^{\circ} 32^{\prime} 26.0^{\prime \prime} \mathrm{W}$ e altitude de $1250 \mathrm{~m}$ ). Os frutos foram higienizados (solução com concentração de 200-250 ppm de cloro por 15 minutos, enxaguados em água corrente) e realizado a retirada mecânica da casca dos frutos para elaboração da farinha, conforme descrito a seguir.

\subsection{ELABORAÇÃO DA FARINHA DA CASCA DE FEIJOA (FCF)}

Para a obtenção da farinha, as cascas de feijoa in natura foram uniformemente distribuídas, e submetidas ao processo de secagem em estufa com circulação de ar forçada a $60^{\circ} \mathrm{C}$ até peso constante (aproximadamente 9 horas). Os resíduos desidratados foram triturados em liquidificador e em seguida em agitador de peneiras da marca Bertel, com 9 de vibração por um tempo de 5 minutos, sendo utilizado peneiras de $0,6 \mathrm{~mm}$. Após obtenção da farinha, foram então realizadas determinações físicas, químicas, potencial antioxidante e análises microbiológicas. 


\subsection{DETERMINAÇÃO FÍSICA, QUÍMICA E POTENCIAL ANTIOXIDANTE DA FARINHA DA CASCA DA FEIJOA}

As variáveis analisadas foram: parâmetros de cor, utilizando colorímetro Konica Minolta, CR 400 - pelos sistemas CIE $1976\left(\mathrm{~L}^{*} \mathrm{a}^{*} \mathrm{~b}^{*}\right)$ e $\mathrm{CIELCH}\left(\mathrm{L}^{*} \mathrm{C}^{*} \mathrm{H}^{\circ}\right)$, atividade de água (analisador marca Labmaster (Novasiana AG)), pH, acidez total titulável, umidade, cinzas, proteínas e lipídeos seguindo as metodologias descritas AOAC (2005), todas realizadas em triplicata. Para determinação dos teores de açúcares, além da sua quantificação, também foi realizada a avaliação individual dos mesmos (sacarose, frutose e glicose), por cromatografia líquida de alta eficiência (CLAE), seguindo a metodologia descrita por Sesta (2006).

Quanto a determinação do potencial antioxidante, foi realizado a quantificação dos teores totais de compostos fenólicos e atividade antioxidante por três métodos. Inicialmente, para obtenção do extrato, foi realizado de acordo com o descrito por Silva (2017), com adaptações: foram pesadas $3 \mathrm{~g}$ da amostra e adicionadas a $80 \mathrm{~mL}$ de água. A mistura obtida foi levada ao shaker e mantida a $200 \mathrm{rpm}$ a $25 \pm 2 \stackrel{\circ}{ } \mathrm{C}$ por um período de 3 horas. 0 extrato obtido foi rotaevaporado a $100 \mathrm{rpm}, 175$ mbar e temperatura do banho de $50 \stackrel{\circ}{\circ}$. Na sequência o extrato foi liofilizado e então foram preparadas soluções estoque de $1000 \mathrm{ppm}$. As adaptações do método de extração foram obtidas em otimização de estudos prévios (dados não apresentados nesse estudo).

Para determinação do teor total de compostos fenólicos foi utilizado o método de Folin-Ciocalteau de acordo com o descrito por Singleton et al., (1999). Já a atividade antioxidante foi determinada por três métodos: por ABTS de acordo com o descrito por RE et al. (1999), por de redução do ferro (FRAP) de acordo com Benzie \& Strain (1996) e através da atividade sequestrante do radical DPPH - 2,2-diphenyl -1picrylhydrazyl, realizada a partir da solução de Trolox, conforme a metodologia descrita por BrandWilliams, Cuvelier \& Berset (1995).

Os resultados das determinações foram apresentados como média \pm desvio padrão.

\subsection{ANÁLISE MICROBIOLÓGICA DA FARINHA DA CASCA DE FEIJOA}

Amostras da farinha foram submetidas também à avaliação microbiológica, as quais foram realizadas com base no Regulamento técnico de padrões microbiológicos para alimentos - RDC no12 (Brasil, 2001), com pesquisa de Salmonella sp. adotando o método BAM/FDA (Andrews \& Hammack, 2006) e coliformes totais a $35{ }^{\circ} \mathrm{C}$ e termotolerantes a $45{ }^{\circ} \mathrm{C}$ de acordo com a IN 62, MAPA (Brasil, 2003). Para as contagens de Staphylococcus aureus e bolores e leveduras, foi utilizada a metodologia da Americam Public Health Association (APHA, 1992). Para a contagem de Bacillus cereus e Clostrídios sulfito redutores foram realizados com base no método de referência ISO 7932:2004 e ISO 15213:2003.

\section{RESULTADOS E DISCUSSÃO}

\subsection{CARACTERIZAÇÃo FíSICA, QUÍMICA E POTENCIAL ANTIOXIDANTE DA FARINHA DA CASCA DE FEIJOA}

No que se refere aos atributos de cor, Moretto et al (2014b), descreve que a parte externa da casca (película) é verde, podendo variar de verde cinza até verde oliva. No quesito luminosidade o resultado obtido nesse estudo (tabela 1) de 42,70 está mais próximo em relação ao escuro, valor tal similar ao encontrado por Amarante et al. (2013) com valores de $L^{*}$ da casca de frutos de goiabeira-serrana em diferentes cultivares, entre 43,6 a 46,3. Os valores obtidos para a componente $a^{*}$ de cor que varia de verde (negativo) a vermelho (positivo) e b* do azul (negativo) a amarelo (positivo) obtiveram valores de 1,47 e 12,99, indicando baixa intensidade ao vermelho e próximo ao amarelo, esperado em função da coloração visual dos frutos. Quanto ao ângulo $h u e\left(h^{\circ}\right)$ pode ser atribuído como cor do produto. 0 valor encontrado de 83,44 (tabela 1) se difere dos encontrados nas cascas de goiaba-serrana relatados por Amarante et al (2013), que descreveu valores próximos a 120. No entanto, essa variação pode ser atribuída ao processo de secagem, levando a uma alteração em tal variável.

Além da cor como importante atributo de qualidade, principalmente sensorial, a atividade de água é também um fator determinante na estabilidade microbiológica e atividade enzimática dos produtos, onde valores próximos a 1 aumentam a probabilidade de reações químicas, físicas, microbiológicas ou enzimáticas, sendo assim, o controle de atividade de água e umidade fatores fundamentais na preservação da qualidade do produto (Kabiri et al. 2016). Chisté et al (2006), na caracterização físico-química de 
amostras de farinha de mandioca obteve valores de $a_{w}$, de 0,310 a 0,610, faixa tal similar ao encontrado nesse estudo, de 0,506.

Tabela 1 - Características físicas, químicas e potencial antioxidante de farinha da casca de feijoa.

\begin{tabular}{|c|c|}
\hline Variável & Média \pm DP \\
\hline $\mathrm{L}^{*}$ & $42,70 \pm 0,09$ \\
\hline a* & $1,47 \pm 0,04$ \\
\hline $\mathrm{b}^{*}$ & $12,99 \pm 0,11$ \\
\hline$h^{*}$ & $83,44 \pm 0,08$ \\
\hline Atividade de água & $0,506 \pm 0,00$ \\
\hline $\mathrm{pH}$ & $2,80 \pm 0,00$ \\
\hline Acidez total titulável (\% de ácido cítrico) & $1,91 \pm 0,13$ \\
\hline Umidade (\%) & $14,60 \pm 0,00$ \\
\hline Cinzas (\%) & $2,63 \pm 0,00$ \\
\hline Proteína (\%) & $3,45 \pm 0,03$ \\
\hline Lipídeos (\%) & $2,98 \pm 0,01$ \\
\hline Sacarose (\%) & $0,00 \pm 0,00$ \\
\hline Glicose (\%) & $3,54 \pm 1,59$ \\
\hline Frutose (\%) & $5,23 \pm 0,79$ \\
\hline CFT (mg EAG g $\left.{ }^{-1}\right)$ & $103,07 \pm 0,53$ \\
\hline DPPH $(\mu \mathrm{mol}$ Trolox g-1 $)$ & $667,72 \pm 0,04$ \\
\hline ABTS $(\mu$ mol Trolox g-1) & $1101,11 \pm 1,92$ \\
\hline FRAP $\left(\mu \mathrm{mol} \mathrm{Fe}{ }^{2+} \mathrm{g}-1\right)$ & $2479,52 \pm 1,09$ \\
\hline
\end{tabular}

Desvio Padrão (DP), Luminosidade ( $\mathrm{L}^{*}$ ), ângulo hue $\left(h^{*}\right)$, Acidez total titulável (ATT). Compostos fenólicos totais (CFT) $\left(\mathrm{mg} \mathrm{EAG} \mathrm{g}^{-1}\right)$, DPPH $\left(\mu \mathrm{mol}\right.$ Trolox g-1), ABTS $\left(\mu \mathrm{mol}\right.$ Trolox g-1), FRAP $\left(\mu \mathrm{mol} \mathrm{Fe}^{2+} \mathrm{g}^{-1}\right)$.

Assim como a atividade de água atua como um obstáculo frente a reações nos alimentos, o pH apresenta também tal atuação, uma vez que é um fator intrínseco ao produto, ligado também ao sabor, odor, atividade das enzimas e crescimento de microrganismos (Fernandes et al, 2008). Sendo assim o pH da farinha age como um fator de impedimento para o desenvolvimento microbiano no produto. Nesse estudo, os valores obtidos foram de 2,8 indicando um produto ácido. Valores próximos ao pH desta pesquisa (tabela 1) formam relatados por Kabiri et al (2016) com 3,1 de pH em pesquisa sobre as propriedades físico químicas do extrato de ervas secas de feijoa. Valores inferiores de $\mathrm{pH}$, pode estar relacionado com a presença de ácidos orgânicos na casca do fruto, reduzindo o pH e aumentando a acidez das farinhas (Neto, 2012).

Ligado ao pH o resultado de ATT obtido foi de 1,91 g de ácido cítrico $100 \mathrm{~g}^{-1}$, Chitarra e Chitarra (2005), explanam que a acidez titulável dos frutos é determinada pela presença de ácidos orgânicos que reduzem devido a maturação do fruto decorrente da oxidação no ciclo dos ácidos tricarboxilicos. Quanto ao teor de umidade, a FCF está condizente com o estabelecido pela Resolução $n^{\circ} 263$, de $2005 b$, a qual aprova o regulamento técnico para produtos de cereais, amidos, farinhas e farelos é estabelece que o teor de umidade máxima deve ser de 15,0\% (g.100g ${ }^{-1}$ ). E entre 13,0 a 15,0\% para os diversos tipos de farinha classificados de acordo com a CNNP ${ }^{\circ} 12,1978$ (BRASIL, 1978).

Quando comparado o percentual de cinzas com a farinha de trigo, o valor encontrado foi de 2,63\% enquanto a farinha prevê um máximo de 2,50\% de cinzas de acordo com a instrução normativa $\mathrm{n}^{\circ} 8$, de 2005 (BRASIL, 2005a). Já a resolução CNNP n 12, 1978 (Brasil, 1978) estabelece um limite máximo de 6\% de cinzas em algumas farinhas vegetais, deste modo o valor encontrado fica de acordo com a legislação. Valores superiores deste parâmetro pode ser provavelmente a maior presença de minerais em cascas de frutas. De modo geral, valores próximos de umidade e cinzas foram citados por Alcântara et al (2012).

Em relação ao teor de proteínas $(3,45)$ e lipídeos $(2,98)$ encontrados nesse estudo são similares a outros estudos com feijoa (Bertagnolli et al., 2014). Bem como, Souza et al (2016) que caracterizou farinha da casca do jenipapo quanto ao proteína e lipídeos e identificou valores de 1,78\% e 2,8\%, próximos aos relatados nesse documento. Variações encontradas de uma maneira geral podem ser explicadas em função de vários fatores como matriz analisada, fatores edafoclimáticos, cultivo e cultivares.

Para finalizar as variáveis físico-químicas, também de grande relevância na qualidade dos alimentos são os açúcares. A FCF não apresentou teores passíveis de detecção de sacarose (tabela 1). Já para glicose e frutose os valores foram de 2,85\% e 5,86\%, respectivamente. Valores tais próximos aos relatados por Augusta et al (2010) ao avaliar açúcares redutores em casca de jambo vermelho, identificando valores de 3,04 (g glicose $100 \mathrm{~g}^{-1}$ de casca). 
O potencial antioxidante e teor de compostos fenólicos da FCF também foram analisados nesse estudo e seguem apresentados na tabela 1. Foram obtidos valores de CFT de 103,07 mg EAG g-1, esses valores são similares aos encontrados por Amarante et al. (2017). Da mesma forma, os valores de atividade antioxidante dos diferentes métodos utilizados nesse estudo (ABTS, DPPH e FRAP) são similares a outros estudos relatados na literatura (Isobe et al., 2003). Os resultados corroboram ao fato de que a casca da feijoa é uma potencial fonte de compostos bioativos, como os fenólicos e atividade antioxidante (Amarante et al., 2017; Weston, 2010). De fato, esses compostos podem alterar em função de diversos fatores, conforme supracitado para as variáveis físicas e químicas.

\subsection{CARACTERIZAÇÃO MICROBIOLÓGICA DA FARINHA DA CASCA DE FEIJOA}

Os dados microbiológicos da amostra da farinha de feijoa mostraram ausência de Salmonella sp., e padrões aceitáveis de Coliformes totais a $35^{\circ} \mathrm{C}(<3,0 \mathrm{NMP} / \mathrm{g})$, Coliformes termotolerantes $(<3,0 \mathrm{NMP} / \mathrm{g})$, Estafilococos coagulase positiva $(<10,0 \mathrm{UFC} / \mathrm{g})$, Bolores e leveduras $\left(<1,0 \times 10^{2} \mathrm{UFC} / \mathrm{g}\right)$, Bacillus cereus e Clostridios sulfito redutores $\left(<1,0 \times 10^{1} \mathrm{UFC} / \mathrm{g}\right)$.

Dentre os padrões estabelecidos pela Resolução RDC n 12 de 2001, item 1c, frutas, produtos de frutas e similares (desidratadas secas) devem obedecer para coliformes termotolerantes a $45{ }^{\circ} \mathrm{C}$ máximo de $10^{2}$ UFC/g e ausente para salmonela sp em 25g (BRASIL, 2001). Além disso a legislação não preconiza padrões para bolores e leveduras em frutas, produtos de frutas e similares, secos ou desidratadas. Entretanto, estes microrganismos são indicadores da qualidade e segurança dos alimentos, tornando esta análise relevante. Deste modo, baixas contagens indicam boa condição higiênica nos produtos. Outro indicador de qualidade higiênica insatisfatória é a presença de coliformes.

Neto et al (2004) relacionam a baixa atividade microbiológica em farinhas ao baixo nível de contaminação das amostras durante o processamento, manipulação, armazenamento e outros condições pouco favoráveis das amostras para o desenvolvimento dos microrganismos. Os resultados indicam que a farinha não indicou ocorrência de microrganismos deteriorantes que possam comprometer a qualidade e estabilidade do produto. As boas práticas de fabricação aplicadas no desenvolvimento do produto auxiliaram na obtenção de um produto qualidade.

\section{CONCLUSÃO}

A incorporação e aproveitamento de resíduos da indústria de alimentos, como a FCF, pode vir a ser uma potencial alternativa para aplicação e agregação de valor em diferentes produtos alimentícios, pelas suas propriedades físico-químicas, qualidade microbiológica e principalmente pela presença de compostos fenólicos e atividade antioxidante, relacionados a benefícios à saúde.

\section{REFERÊNCIAS}

[1] Alcântara, S. R.; Sousa, C. A. B. De.; Almeida, F. A. C. De.; Gomes, J. P. (2012). Caracterização físico-quimica das farinhas do pedúnculo do caju e da casca do maracujá. Revista Brasileira de Produtos Agroindustriais, 14 (especial) 473-478. Campina Grande.

[2] Aquino, A. C. M. S.; Móes, R. S.; Leão, K. M.M; Figueiredo, A. V. D.; Castro, A. A. (2010). Avaliação físico-química e aceitação sensorial de biscoitos tipo cookies elaborados com farinha de resíduos de acerola. Revista Instituto Adolfo Lutz, 69(3), 379-86.

[3] Amarante, C.V.T.; Steffens, C.A.; Beninca, T.D.T.; Hackbarth, C. Santos, K.L. (2013). Qualidade e potencial de conservação pós-colheita de frutos em cultivares brasileiras de goiaba-serrana. Revista Brasileira de Fruticultura, 35(4), 990-999.

[4] Amarante, C. V. T. Do.; Souza, A. G. De.; Benincá, T. D.T.; Steffens, C. A. (2017). Phenolic content and antioxidant activity of fruit of Brazilian genotypes of feijoa. Pesquisa Agropecuária Brasileira, 52 (12), 1223-1230.

[5] Benzie, I. F. F.; Strain, J. J.(1996). The ferric reducing ability of plasma (FRAP) as a measure of "antioxidant power": The FRAP assay. Analytical Biochemistry, 15 (1), 70-76.

[6] Bertagnolli, S. M. M.; Silveira, M. L. R.; Fogaça, A. De. O.; Umann, L.; Penna, N. G. (2014). Bioactive compounds and acceptance of cookies made with Guava peel flour. Food Science and Technology, 34(2), 303-308.

[7] Brand-Williams, W.; Cuvelier, M. E.; Berset, C. (1995). Use of a free radical method to evaluate antioxidant activity. Food Science and Technology, 28(1), 25-30. 
[8] Brasil. (1978). Comissão Nacional de Normas e Padrões para Alimentos. Resolução n 12, de julho 1978. Brasília, DF.

[9] Brasil. Ministério da Saúde. Agência Nacional de Vigilância Sanitária. (2001). Resolução - RDC n 12, de 2 de janeiro de 2001. Regulamento técnico que dispõe sobre padrões microbiológicos e sanitários para alimentos. Brasília, DF.

[10] Brasil. Ministério da Agricultura, Pecuária e Abastecimento (MAPA). (2003). Instrução normativa $n^{\circ}$ 62, de 26 de agosto de 2003. Oficializa os métodos analíticos oficiais para analises microbiológicas para controle de produtos de origem animal e água. Diário oficial da União.

[11] Brasil, Ministério da Agricultura, Pecuária e Abastecimento. (2005a). Instrução Normativa n.o 8, de 02 de junho de 2005. Regulamento Técnico de Identidade e Qualidade da Farinha de Trigo. Brasília.

[12] Brasil. Ministério da saúde. Agência Nacional de Vigilância Sanitária (ANVISA).(2005b). Resolução $n^{\circ} 263$, de 22 de setembro de 2005. Aprova o regulamento técnico para produtos de cereais, amidos, farinhas e farelos. Diário Oficial da União.

[13] Chisté, R. C.; Cohen, K. De. O.; Mathias, E. De. A.; Ramoa Júnior, A. G. A. (2006). Qualidade de farinha de mandioca do grupo seca. Ciência e Tecnologia de Alimentos, 26(4), 861-864.

[14] Isobe, Y.; Kase, Y.; Narita, M.; Komiya, T. (2003). Antioxidative activity of the tropical fruit, Feijoa sellowiana Berg. Journal of Home Economics of Japan, 54(1) 945 - 949.

[15] Kabiri, S.; Gheybi, F.; Jokar, M.; Basiri, S. (2016). Antioxidant activity and physicochemical properties of fresh, dried and infused herbal extract of Feijoa Fruit. Nature and Science, 14(12).

[16] Madamba, P. S.; Driscoll, R. H.; Buckle, K. A. (2007) The thinlayer drying characteristics of garlics lices. Journal of Food Engineering, 29(2), 75-97.

[17] Moretto, S. P. (2014a). A domesticação e a disseminação da feijoa (Acca sellowiana) do século XIX ao século XX. (Tese Doutorado em História). Universidade Federal de Santa Catarina, Florianópolis, SC.

[18] Moretto, S.P.; Nodari, E.S.; Nodari, R.O. A. (2014b). Introdução e os Usos da Feijoa ou Goiabeira Serrana (Acca sellowiana): A perspectiva da história ambiental. Fronteiras: Journal of Social, Technological and Environmental Science, 3(2), 67-79.

[19] Re, R.; Pellegrini, N; Proteggente, A.; Pannala, A.; Yang, M.; Riceevans, C. (1999). Antioxidant activity applying an improved ABTS radical cation decolorization assay. Free Radical Biology \& Medicine, 26(9/10), 1231- 1237.

[20] Sesta, G. Determination of sugars in royal jelly by HPLC1. Istituto Sperimentale per la Zoologia Agraria, Sezione di Apicoltura, Rome, Italy. Apidologie, v. 37, n. 1, 2006.

[21] Silva, A. P. S. (2017). Avaliação do potencial antioxidante dos extratos da folha da goiaba - serrana (Acca sellowiana (O. Berg.)Burret). (Trabalho de Conclusão do Curso - Graduação). Universidade Federal de Santa Catarina, Florianópolis, SC.

[22] Singleton, V. L.; Orthofer, R.; Lamuela, R. M. (1999) Analysis of total phenols and other oxidation substrates and antioxidants by means of Folin-Ciocalteu reagent. Methods of Enzymology, 299, 152-178.

[23] Souza, F. P.; Morais, J. L.; Silva, T. M. C. F. (2016). Desenvolvimento e caracterização de farinha obtida a partir da casca do jenipapo (Genipa americana L.). XXV Congresso Brasileiro de Ciencia e Tecnologia de Alimentos. Gramado, RS.

[24] Zanatta, C. L.; Schlabitz C.; Ethur E. M. (2010). Avaliação físico-química e microbiológica de farinhas obtidas a partir de vegetais não conformes a comercialização. Alimentos e Nutrição Araraquara, 21(3) 459-468.

[25] Weston, R. J. (2010). Bioactive products from fruit of the feijoa (Feijoa sellowiana, Myrtaceae): a review. Food Chemistry, 121(4), 923-926. 


\section{Capítulo 20}

Atuação do tecnólogo em alimentos em uma panificadora no município de Quixeramobim - CE

\section{Maria Luciene Monteiro Mendes}

\section{Cláudio Gonçalves Paulino}

Sheyla Maria Barreto Amaral

\section{Ticiana Leite Costa}

\section{Liliane Fernandes do Nascimento}

Resumo: Realizar ações de melhorias embasadas nas Boas Práticas promovem maior garantia da qualidade dos produtos produzidos em unidade de panificação. Avaliar o cumprimento das BPF's na área de produção em uma panificadora localizada no município de Quixeramobim - CE, orientando colaboradores e observando não conformidades visando aplicar medidas corretivas, foram os objetivos deste trabalho. Foram observadas a condução das atividades laborais durante o expediente e identificados os pontos para modificação. Realizaram-se mudanças no setor de produção, como higienização das lixeiras e armários de fermentação, organização da pia e bebedouro e acesso adequado às instalações sanitárias. Realizou-se seminário integrativo entre colaboradores e a proprietária, com objetivo de apresentar o diagnóstico da panificadora e a importância das Boas Práticas nesse tipo de estabelecimento. Conclui-se que a implantação das BPF's por meio da atuação do Tecnólogo em Alimentos auxilia na oferta de produtos de melhor qualidade e seguros para o consumo.

Palavras-chave: Boas Práticas de Fabricação, pães, segurança alimentar, higienização, manipuladores. 


\section{INTRODUÇÃO}

Segundo Canella-Rawls (2012), na Idade Média, o pão era sinônimo de status, pois somente os nobres tinham acesso à farinha de maior qualidade. No Brasil, o pão foi introduzido pelos portugueses desde o inicio da colonização. Foi apenas no século XX que os imigrantes italianos se encarregaram de expandir a panificação em território nacional.

A grande mudança na produção dos pães veio com a revolução industrial, pela utilização de máquinas, alterando-se progressivamente muitos processos produtivos (SERAFINI, 2006). 0 desenvolvimento do setor de panificação acentuou a concorrência, trouxe inovações nos relacionamentos comerciais entre fornecedor-produtor-cliente (SEBRAE, 2010).

As panificadoras no Brasil têm passado por transformações nos últimos anos, principalmente a partir da década de 90, quando se percebeu a incorporação de novos serviços e diversificação que reconfigurou o negócio, ampliando o oferecimento dos produtos tradicionais e se colocando como locais de consumo durante todo o dia, principalmente dentro dos conceitos de foodservice (SEBRAE, 2015).

Diante da importância da panificação para a segurança alimentar da sociedade, as Boas Práticas de Fabricação, conservação e distribuição dos alimentos panificados tornam-se indispensáveis. Para Serafini (2006) os manipuladores de alimentos são os principais transmissores de bactérias que são os maiores causadores de doenças alimentares. Essas bactérias são transmitidas por secreções nasais, cabelos, mãos, suor, coliformes fecais, entre outros.

Segundo Bastos (2008), as Boas Práticas de Fabricação (BPF’s) são um conjunto de princípios e regras para o manuseio correto dos alimentos, abrangendo desde as matérias-primas até o produto final, de forma a garantir a segurança e a integridade do consumidor. De acordo com Moro et al. (2015), a principal vantagem da implantação do programa de Boas Práticas é a garantia de produtos de melhor qualidade e mais seguros, sendo a saúde pública a maior beneficiária.

As doenças alimentares, que são transmitidas por alimentos contaminados ou em má conservação vêm crescendo expressivamente em todo mundo. Vários são os fatores que contribuem para seu aumento, dos quais se destacam: a má manipulação dos alimentos, o aumento da população desordenada, alguns indivíduos vulneráveis ou expostos às condições mínimas de saúde, higiene e alimentação, a urbanização descontrolada, e a produção de alimentos em grande escala (PEREIRA; SILVA; TEIXEIRA, 2015).

Diante do exposto, o objetivo do presente trabalho foi avaliar o cumprimento das Boas Práticas de Fabricação na área de produção em uma panificadora no município de Quixeramobim, estado do Ceará, orientando os colaboradores e observando as não conformidades visando aplicar as medidas corretivas caso necessário.

\section{MATERIAIS E MÉTODOS}

Os manipuladores foram orientados para o cumprimento das normas de Boas Práticas de Fabricação, conforme a Resolução $\mathrm{n}^{\circ} 216$ da ANVISA (BRASIL, 2004), e foram acompanhados diariamente. A conscientização sobre a importância das BPF's para a saúde alimentar do consumidor foi realizada através de treinamentos e acompanhamento diário do processo de fabricação. As medidas corretivas foram realizadas, garantindo a qualidade nos produtos elaborados. Por fim, realizou-se um seminário de integração com todos os colaboradores.

\section{RESULTADOS E DISCUSSÃO}

Os resultados deste trabalho comprovaram a importância das Boas Práticas de Fabricação. Pode-se dar ênfase a incidência de problemas relacionados com as edificações, as quais se destacaram pela frequente constatação da falta de higienização dos equipamentos e utensílios.

Inicialmente os funcionários colocaram muita resistência para o uso de Equipamentos de Proteção Individual (EPI) obrigatório, como luvas, toucas, entre outros. Foi feito um diagnóstico crítico do ambiente físico quanto a adequação às Boas Práticas de Fabricação, em seguida foi realizada uma pré-limpeza na área de produção. 
Uma das sugestões de mudanças realizadas foi o acesso às intalações sanitárias. A entrada do banheiro sanitário era dentro da área de produção, e não era higienizado diariamente deixando fortes odores e trazendo riscos de contaminação aos produtos panificados. Foi fechada a entrada interna deixando o acesso ao sanitário somente pela área externa do edifício, tornando o ambiente físico mais adequado para a produção de alimentos. Costa et al. (2017) em sua avaliação das condições higienico-sanitárias e físicoestruturais de panificadoras de uma cidade do nordeste, obtiveram resultados semelhantes, as instalações sanitárias das três padarias não se encontravam separadas da parte de produção, ocasionando possíveis riscos de contaminação.

Os armários de fermentação de pães foram higienizados de forma adequada. Na entrada da área de produção era colocado todo o material de limpeza, aos poucos foi possível fazer a organização do ambiente, retirando os objetos obsoletos e inadequados que estavam em cima da pia. Foi possível organizar o espaço e colocar na pia um kit para higienização das mãos. Também foram colocados equipamentos para o manuseio da produção de forma correta e um suporte para o garrafão de água.

As lixeiras que ficavam dentro da área de produção foram higienizadas para que não promovossem fortes odores. Os equipamentos de produção como masseira, cilindro e divisor foram todos higienizados. Serafini (2006), em seu estudo com a implantação das Boas Práticas em panificadoras de Recife obteve resultados semelhantes ao do presente trabalho, destacando a higienização das lixeiras, melhora na limpeza dos equipamentos e utensílios e na compra ou adequação de móveis e utensílios.

Através da implantação das Boas Praticas de Fabricação, foi possível prover uma reparação no espaço de trabalho dos manipuladores, melhorando assim a condição operacional dos mesmos, conforme observado nas fotografias do ambiente, antes e após as mudanças (Figura 1).

Figura 1 - Ambientes da produção na panificadora, antes e após a aplicação das ações corretivas.

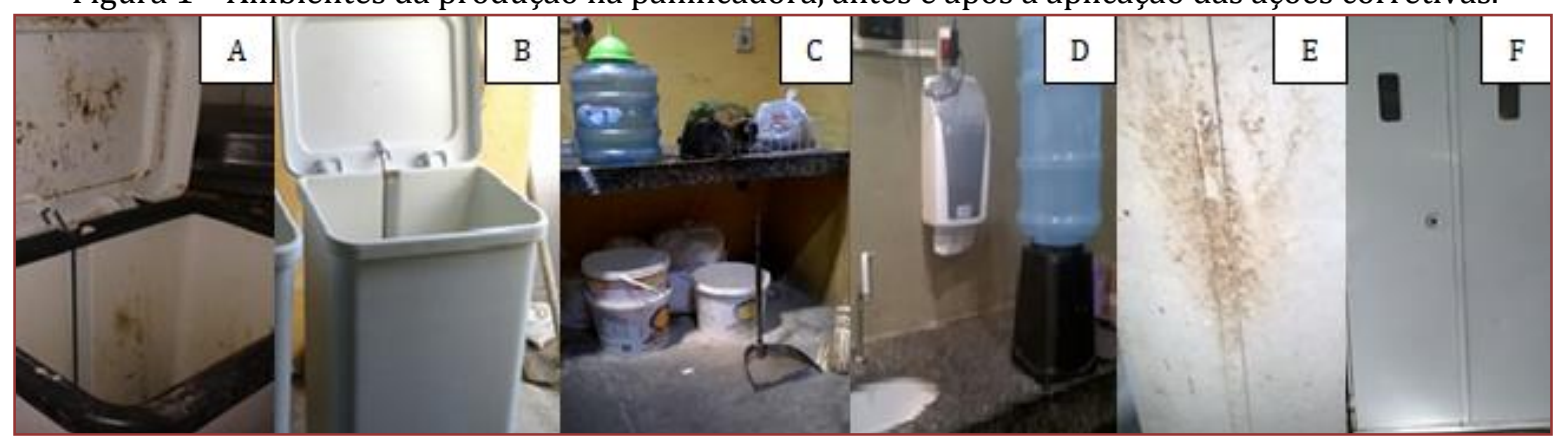

Fonte: Elaborado pelos autores.

Legenda: A-Lixeira suja; B-Lixeira higienizada; C-Pia com objetos obsoletos; D-Pia organizada e com kit para higienização das mãos; E-Armário de fermentação sujo; F-Armário de fermentação higienizado.

O seminário de integração realizado foi fundamental para obter os objetivos previstos e contou com a participação de todos os colaboradores e a proprietária, com a finalidade de mostrar o diagnóstico da panificadora e a importância de trabalhar as Boas Práticas em estabelecimentos de produção de alimentos panificáveis.

Na apresentação do seminário foi abordada à importância das BPF’s em uma indústria de alimentos, e a necessidade de treinamentos dos funcionários a fim de capacitá-los para o desenvolvimento de suas atividades. Foram abordados os riscos físicos, químicos e biológicos e os cuidados que deve-se ter na hora da manipulação. Não é recomendável o uso de adornos como brincos, relógios, bonés, entre outros. Chamando atenção para o cuidado na higienização dos equipamentos e utensílios para o uso de produtos químicos e manter sempre a área da produção limpa, diminuindo assim os riscos biológicos.

Foi falado sobre contaminação cruzada, o risco de um produto cru contaminar um já preparado. No caso os produtos panificados já prontos não podem ser colocados diretamente na bancada, pois a mesma não sendo higienizada corretamente contamina os produtos. A importância de manter a área de trabalho organizada e higienizada, incluindo as superfícies, os utensílios, equipamentos e bancadas. 


\section{CONCLUSÃO}

Os objetivos propostos nesse trabalho foram alcançados, à medida que foram realizados treinamentos com os funcionários sobre Boas Práticas de Fabricação, assim como a organização e higienização dos utensílios e equipamentos utilizados no processo de fabricação. Conclui-se que a implantação das BPF's por meio da atuação do Tecnólogo em Alimentos auxilia na oferta de produtos de melhor qualidade e seguros para o consumo.

\section{AGRADECIMENTOS}

Ao Instituto Centro de Ensino Tecnológico - CENTEC e a Faculdade de Tecnologia CENTEC - Sertão Central, pelos incentivos à disseminação de conhecimentos e contribuição para transformação de realizades através da educação.

\section{REFERÊNCIAS}

[1] BASTOS, M. S. R. Ferramentas da ciência e tecnologia para a segurança alimentar. Fortaleza: EMBRAPA, 2008. $440 \mathrm{p}$.

[2] BRASIL. Agência Nacional de vigilância Sanitária. Resolução RDC no 216, de 15 de setembro de 2004. Dispõe sobre regulamento técnico de Boas Práticas para serviços de alimentação. Diário Oficial da República Federativa do Brasil: seção 1, Brasília, DF, ano 1, p. 25-28, 16 de set. 2004.

[3] CANELLA-RAWLS, S. Pão: Arte e Ciência. São Paulo: Senac, 2012. 5 ed. 352 p.

[4] COSTA, I. R., SANTOS, G. M., OLIVEIRA, J. M. S., SAlDANHA, N. M. V. P., SOUSA, P. V. L., CARVALHO, Á. C. S. Avaliação das Condições Higiênico-Sanitárias e Físico-Estruturais de Panificadoras de uma Cidade do Nordeste $\begin{array}{lllllll}\text { Brasileiro. Revista Uningá } & \text { Review, v. } & 32, & \text { n. } & 1, & \text { p. } & 159-169,\end{array}$ http://34.233.57.254/index.php/uningareviews/article/view/30.

[5] MORO, M. F., BEM, A. R., WEISE, A. D., REIS, C. C. C., SCHMIDT, C. A. P. Avaliação das boas práticas de fabricação em uma panificadora: Um estudo de caso. Espacios, v. 36, n. 9, p. 14, 2015. http://www.revistaespacios.com/a15v36n09/15360914.html.

[6] PEREIRA, M. I. M.; SILVA, J. G.; TEIXEIRA, N. C. Boas Práticas de Fabricação para o Serviço de Alimentação. Revista Pensar Gastronomia, v. 1, n. 2, 2015.

[7] SEBRAE. Serviço Brasileiro de Apoio às Micro e Pequenas Empresas. Boas Práticas na Panificação e na Confeitaria - da Produção ao Ponto de Venda. Brasília: SEBRAE, 2010.

[8] SEBRAE. Serviço Brasileiro de Apoio às Micro e Pequenas Empresas. Painel de mercado da panificação e confeitaria. Brasília: SEBRAE, 2015.

[9] SERAFINI, C. F. A implantação das boas práticas de fabricação em panificadoras da região metropolitana do Recife. Orientador: Maurílio José dos Santos. 2006. 195 p. Dissertação (Mestrado em Engenharia Mecânica) Universidade Federal de Pernambuco, Recife, 2006. 


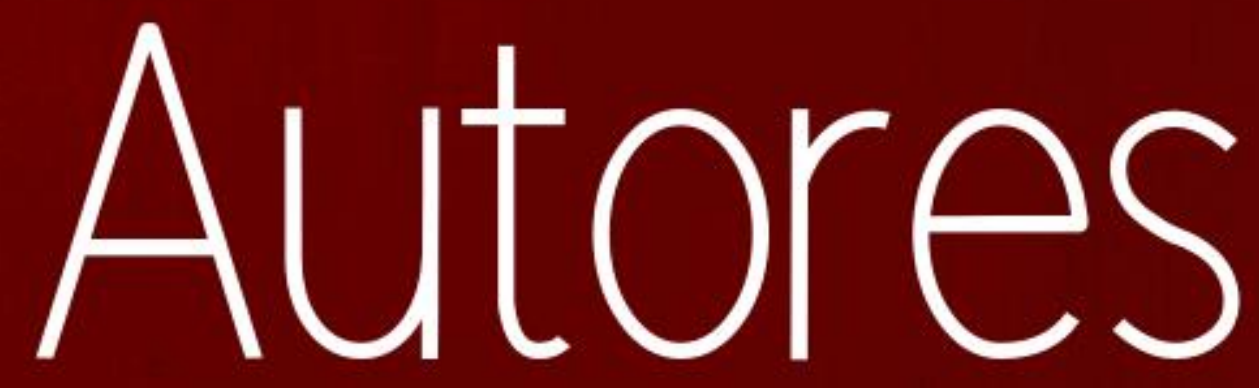




\section{ADRIANA BIASI VANIN}

Graduação, mestrado e doutorado em Engenharia de Alimentos pela Universidade Regional Integrada do Alto Uruguai e das Missões - Erechim. Experiência profissional na área de bebidas fermentadas e destiladas, na área de laticínios, e na área de administração empresarial. Na área acadêmica, conhecimento no equilíbrio de fases à baixas pressões, termodinâmica, biotecnologia, produção de aromas naturais via tecnologia enzimática, ferramentas da qualidade e obtenção de embalagens biodegradáveis. Consultora nível I pelo Programa Alimentos Seguros (PAS) e professora tempo integral e pesquisadora da UNOESC - Universidade do Oeste de Santa Catarina.

\section{ADRIANA DILLENBURG MEINHART}

Possui graduação em Química Industrial de Alimentos, doutorado e pós-doutorado em Ciência de Alimentos. Tem experiência em química de alimentos, química analítica fundamental e instrumental aplicada à análise de alimentos, solos e fluidos biológicos, com ênfase em: 1) Desenvolvimento, otimização e validação de métodos de análise bromatológicas e instrumentais (HPLC, GC, CE e MS); 2) Estudos para desenvolvimento de alimentos funcionais, com avaliação de compostos benéficos e contaminantes; 3) Purificação de padrões analíticos de elevado custo com alto teor de pureza para emprego em análises; 4) Caracterização química e funcional de fontes naturais pouco exploradas; 5) Controle de qualidade em laboratório. Professora Adjunta I do Departamento de Ciência e Tecnologia Agroindustrial da Universidade Federal de Pelotas, onde ministra disciplinas com ênfase em Análise bromatológica de alimentos, Análise instrumental de alimentos, Validação de métodos para análise de alimentos e Planejamento multivariado de experimentos. Revisora de periódicos de elevado impacto na área de Química de alimentos. Possui experiência na execução de projetos de pesquisa em equipe e participa de projetos de extensão promovendo a socialização de conhecimentos entre a universidade, indústria e comunidade.

\section{ADRIANA TEIXEIRA GODOY}

Possui graduação em Química, modalidade Bacharel pela Universidade Estadual de Campinas (2005-2009). Mestre em Química pelo Programa de Pós-graduação em Química da Universidade Estadual de Campinas (2010-2013), com ênfase em Química Analítica, Espectrometria de Massas e análise de biodiesel. Atualmente, doutoranda do Programa de Pós-graduação em Química da Universidade Estadual de Campinas (2013), com ênfase em Química Analítica, Cromatografia Líquida de Alta Eficiência, Cromatografia em Fase Gasosa, Espectrometria de Massas e lipidômica.

\section{ALANE CANGANI ALVES}

Mestre e atualmente doutoranda em Ciências de Alimentos pela Universidade Estadual de Campinas - Unicamp, cujo projeto de pesquisa é baseado no sinergismo técnico-funcional entre proteínas de origem animal e proteínas de origem vegetal. Durante o mestrado trabalhou com determinação simultânea de cafeína e taurina em bebidas energéticas por eletroforese capilar. Trabalha com análise de alimentos através de técnicas Cromatográficas, Espectrometria de Massas, Validação de Metodologias, Planejamento e Otimização de Processos. Foi trainee de inovação do programa Inova Talentos (CNPq-IEL) na empresa Whirlpool Latin America (2015-2016), com foco em desenvolvimento de novos produtos de refrigeração visando a melhoria da preservação de alimentos submetidos a processo de refrigeração e congelamento. Graduada como Engenheira de Alimentos pela Universidade Estadual de Ponta Grossa - UEPG (2011), onde foi representante discente do curso, presidente de empresa júnior e atuou na área cientifica, principalmente nos seguintes temas: carvão ativado, cinética de adsorção compostos fenólicos, queijo Reblochon e Geotrichum Candidum.

\section{ANALU MANTOVANI}

Graduação em Agronomia pela Universidade do Estado de Santa Catarina (2002), mestrado em Manejo do Solo pela Universidade do Estado de Santa Catarina (2005), doutorado em CIENCIA DO SOLO - UFRGS pela Universidade Federal do Rio Grande do Sul (2009). Atualmente é professora da Universidade do Oeste de Santa Catarina. Tem experiência na área de Agronomia, com ênfase em 
Fertilidade do Solo e Adubação, atuando principalmente nos seguintes temas: nutrição vegetal, analises de solo, fertilidade de solo. Tem experiência em analises de laboratório.

\section{ANDRÉIA MARIA FAION}

Formada em Química Industrial, com mestrado e doutorado em Engenharia de alimentos. Atou por 7 anos como professora e pesquisadora no Senai de Chapecó SC com enfoque no desenvolvimento de novos produtos alimentícios . Atualmente é sócia proprietária da Gunas Cake alimentos sem glúten e sem leite Ltda localizada em Chapecó SC.

\section{ANDRESSA BARELLA DE FREITAS}

Especialista em tecnologia e inovação, tecnologia de alimentos, possui 10 anos de experiência em analises microbiológicas, Implantação de ensaios, auditora interna pela ISO 19011. Atualmente responsável técnica de laboratório de Microbiologia de alimentos.

\section{ANDRESSA ELLEN CASTRO SOUSA}

Técnica em Agroindústria pelo IFMA São Luís - Campus Maracanã Aluna do curso Tecnologia em Alimentos do IFMA São Luis - Campus Maracanã

\section{ANDREZZA DA SILVA RAMOS}

Formada em Química pela Universidade Federal do Amazonas (UFAM) em 2010. Durante meu mestrado e doutorado, trabalhou nas áreas de produtos naturais, química de alimentos, com foco na caracterização química de matrizes complexas de frutas não-convencionais amazônicas e quantificação de vitamina C e substâncias com potenciais antioxidantes e antiglicantes em polpas, sementes e cascas de frutas usando espectrometria de massa e espectroscopia de ressonância magnética nuclear (RMN).

\section{ANDRINE MENNA FONTOURA}

Tecnóloga em Alimentos, mestre e doutoranda em Ciência e Tecnologia em Alimentos pela Universidade Federal de Santa Maria (UFSM), especialização em andamento em Ciência e Tecnologia em Alimentos (UFPel), Licenciada no Programa de Formação de Professores com ênfase em Produção Alimentícia (PEG-UFSM). Consultorias e treinamentos de produtos voltados para análise microbiológica na 3M Food Safety, atualmente consultora técnica de vendas da Labtec, produtos para laboratórios e microbiologia.

\section{ARIANE BARBO MARETOLI}

Acadêmica do 7 @ semestre do curso de Nutrição da Universidade Federal do Pampa, campus Itaqui

\section{BRUNA ALBIERO}

Graduanda do curso de Engenharia Química pela Universidade do Oeste de Santa Catarina Unoesc, campus Joaçaba. Atualmente bolsista do Conselho Nacional de Desenvolvimento Científico e Tecnológico ( $\mathrm{CNPq})$, atuando como pesquisadora na área das propriedades químicas e biológicas em produtos naturais.

\section{BRUNA DE OLIVEIRA ARAÚJO}

Atua principalmente nas áreas de Controle, Gestão de Qualidade e Segurança de Alimentos. Graduação em Nutrição pela Universidade Federal do Rio de Janeiro (UFRJ). 


\section{BRUNA SEGUENKA}

Graduada em Engenharia de Alimentos pela Universidade de Passo Fundo (UPF) (2012), titulada com o grau de Mestre em Ciência e Tecnologia de Alimentos (UPF) (2016) e atualmente estudante de Doutorado em Engenharia de Alimentos (URI Erechim). Experiência na área de processo de separação por membranas com ênfase em vinhos e soro de leite e extração de antioxidantes.

\section{CARINA MORO BENIS}

Formada em Tecnologia em Alimentos pela Universidade Tecnológica Federal do Paraná (UTFPRLD). Participou de projetos de extensão junto a produtores rurais e grupos de economia solidária prestando consultoria para microempresas do setor alimentício. Já proferiu palestras e cursos na área de tecnologia de alimentos. Atualmente é estudante de Pós-Graduação (mestrado) em Ciência de Alimentos pela Universidade Estadual de Londrina (UEL).

\section{CARLA CRISTINA BAUERMANN BRASIL}

Possui graduação em Nutrição pela Universidade Franciscana (2006), especialização em Qualidade de Alimentos pelo Centro Brasileiro de Estudos Sistêmicos (2008), especialização em Higiene e Segurança Alimentar pela Universidad de León (2011), Licenciatura pelo Programa Especial de Graduação de Formação de Professores para a Educação Profissional (2013), Mestrado e Doutorado em Ciência e Tecnologia dos Alimentos pela Universidade Federal de Santa Maria (UFSM) na linha de pesquisa Qualidade de Alimentos e especializanda em Vigilância Sanitária e Qualidade dos Alimentos (2020). Atua como docente do Curso de Nutrição da Universidade Federal de Santa Maria - campus Palmeira das Missões e participa de projetos de pesquisa e extensão na área de ciência e tecnologia de alimentos, com ênfase em sistemas de controle de qualidade de alimentos, microbiologia dos alimentos, análise sensorial de alimentos e legislações sanitárias voltadas a serviços de alimentação e indústria de alimentos. Atualmente além de docente do Curso de Nutrição exerce o cargo de vice-diretora do Restaurante Universitário da UFSM.

\section{CAROLINA PINTO DE CARVALHO MARTINS}

Graduação em Nutrição (2014) pela Universidade Federal do Rio de Janeiro (UFRJ), Mestrado (2017) e cursa Doutorado em Ciência e Tecnologia de Alimentos pelo Instituto de Tecnologia da Universidade Federal Rural do Rio de Janeiro. Atuou como Professora substituta no Instituto de Nutrição Josué de Casto/UFRJ de agosto de 2017 até agosto de 2019 nas disciplinas de Técnica dietética e culinária I, Composição de alimentos, Bromatologia, Nutrição básica e Estágio em ciência de alimentos. Tem experiência na área Ciência e tecnologia de alimentos, atuando principalmente nos temas: análise físico-química de alimentos, desenvolvimento de novos produtos alimentícios, análise sensorial de alimentos, processamento de frutas e hortaliças, processamento de leite e derivados.

\section{CLÁUDIO GONÇALVES PAULINO}

Possui graduação em CURSO SUPERIOR DE TECNOLOGIA EM ALIMENTOS pela FACULDADE DE TECNOLOGIA CENTEC - SERTÃO CENTRAL (2014) e mestrado em CURSO DE MESTRADO EM TECNOLOGIA DE ALIMENTOS - IFCE - Campus Limoeiro do Norte (2019). Atualmente é Professor/Coordenador do Eixo de Produção Alimentícia da Faculdade de Tecnologia CENTEC Sertão Central. Tem experiência na área de Ciência e Tecnologia de Alimentos, com ênfase em Tecnologia de Alimentos, atuando principalmente nos seguintes temas: qualidade, controle térmico, higiene, geleia mista e unidades de alimentação e nutrição.

\section{CLEIDIANA FURTADO TEIXEIRA BELFORT}

Técnica em Agroindústria pelo IFMA São Luís - Campus Maracanã Tecnóloga em Alimentos pelo IFMA São Luís - Campus Maracanã 


\section{CRECIANA MARIA ENDRES}

Professora e Pesquisadora da Faculdade Senai de Chapecó. Graduada em Tecnologia de Alimentos -SENAI. Especialista em Gestão para Segurança de Alimentos - SENAI. Mestre em Ciência e Tecnologia de Alimentos - UPF. Doutoranda em Ciência e Tecnologia de Alimentos - UFRGS. Tem experiência na área de Ciência e Tecnologia de Alimentos, com ênfase em tecnologia de produtos de origem animal.

\section{CRIVIAN PELISSER}

Formada em Engenharia Química, com Mestrado em Ciências Ambientais. Atualmente é Doutoranda no Programa de Pós-Graduação em Engenharia Química da UFPR. Atua como Professora e pesquisadora no Senai em Chapecó, SC.

\section{DAIANA MENIN}

Mini currículo: Possui graduação em Tecnologia de Alimentos pela Universidade Tecnológica Federal do Paraná, Francisco Beltrão (2011). Possui Pós Graduação Lato Sensu em Segurança Alimentar, Políticas Públicas e Tecnologia Agroindustrial pela Universidade Estadual do Oeste do Paraná - UNIOESTE, Francisco Beltrão - PR (2013).Possui mestrado em Tecnologia de Processos Químicos e Bioquímicos pela Universidade TecnológicaFederal do Paraná, Pato Branco (2020),na linha de pesquisa de alimentos, com enfoque na área de frutas e hortaliças.

\section{DOUGLAS SODRE FERREIRA}

Técnica em Agroindústria pelo IFMA São Luís - Campus Maracanã Aluno do curso Tecnologia em Alimentos do IFMA São Luis - Campus Maracanã

\section{EDIMIR ANDRADE PEREIRA}

Professor Adjunto da Universidade Tecnológica Federal do Paraná - Câmpus Pato Branco. Possui Graduação em Química Industrial pela Universidade Estadual da Paraíba (1997), graduação em Docência no Ensino Fundamental e Médio pela Universidade Cândido Mendes (2008), Mestrado em Engenharia Agrícola pela Universidade Federal da Paraíba (2001) e Doutorado em Tecnologia de Processos Químicos e Bioquímicos pela Universidade Federal do Rio de Janeiro (2007). Atuando principalmente nos seguintes temas: Reologia de Alimentos, Processamento de Frutas e Hortaliças, Processamento de Leite e Derivados, Drageamento de Alimentos.

\section{ELISA SONZA}

Mestre em Ciência e Tecnologia de Alimentos pela Universidade do Estado de Santa Catarina (UDESC). Graduada em Tecnologia em Alimentos - Faculdade SENAI (2006), Especialista pelo MBA em Engenharia de Produção pela UCEFF (2014). Atualmente é Coordenadora da Graduação Tecnológica em Alimentos, das Pós-Graduações e Cursos de extensão na área de alimentos da Faculdade SENAI Chapecó. Docente da Pós Graduação e graduação, com experiência em microbiologia, microscopia de alimentos e tecnologia de frutas e hortaliças. Auditora interna nas normas ABNT NBR ISO/IEC 17025:2017 de laboratórios de alimentos e água.

\section{ELLEN CRISTINA PERIN}

Graduação em Tecnologia de Alimentos pela Universidade Tecnológica Federal do Paraná. Possui mestrado (2014) e doutorado (2017) em Ciência e Tecnologia de Alimentos pela Universidade Federal de Pelotas, na linha de pesquisa de frutas e hortaliças. Realizou pós-doutorado na Universidade Federal de Pelotas (2017), seguindo na linha de Ciência e Tecnologia de Alimentos. Atuou recentemente na Universidade Tecnológica Federal do Paraná, campus Francisco Beltrão, como Professora Substituta (2017-2019). Atualmente está vinculada ao Programa de PósGraduação em Processos Químicos e Bioquímicos, como bolsista de pós-doutorado, na Universidade Tecnológica Federal do Paraná, campus Pato Branco. 


\section{ELLEN DE SOUZA ALMEIDA DUARTE}

Mestre em Tecnologia de Processos Químicos e Bioquímicos pela Universidade Tecnológica Federal do Paraná (2020), Bacharela em química industrial pela Universidade Estadual da Paraíba (2018). Participou de programa de intercâmbio acadêmico (2015) na Universidad Nacional del Sur (Argentina) como parte de seus estudos para obtenção do título de Bacharel.

\section{FABRÍCIA QUEIROZ MENDES}

Engenheira de Alimentos, Mestre em Ciência e Tecnologia de Alimentos, Doutora em Bioquímica Agrícola, todos pela Universidade Federal de Viçosa Atualmente é professora no Instituto de Ciências Agrárias da Universidade Federal de Viçosa - Campus Rio Paranaíba

\section{FELIPE OZORIO GIACOMELLI}

Tecnólogo em Alimentos graduado pela Universidade Federal de Santa Maria (UFSM). Mestre em Biotecnologia pela Universidade da Beira Interior (Covilhã, Portugal). Durante o mestrado trabalhou com microbiologia, com foco em produção de pigmentos de origem bacteriana. Atualmente é aluno de doutorado no Programa de Pós Graduação em Ciência e Tecnologia em Alimentos (UFSM). Pesquisa na linha de Carnes e Derivados, com foco em aproveitamento de subprodutos para extração de compostos com alto valor agregado. Também é pós-Graduando em Gestão de Qualidade pela Faculdade Única (Grupo Educacional Prominas).

\section{FERNANDA CARLA HENRIQUE-BANA}

Doutora e Mestra em Ciência de Alimentos pela Universidade Estadual de Londrina (UEL). Tecnóloga em Alimentos pela Universidade Tecnológica Federal do Paraná (UTFPR). É pesquisadora (pós-doutoranda) do grupo de pesquisa Fermentados da UEL. Atuou como docente do Curso Técnico em Biotecnologia do Serviço Nacional de Aprendizagem Industrial (SENAI), onde ministrou a disciplina Biotecnologia na Indústria de Alimentos e Bebidas. Atua em projeto de extensão em parceria com a Prefeitura do Município de Londrina na área de Gestão da Qualidade e Segurança de Alimentos.

\section{FERNANDA GERMANO ALVES GAUTÉRIO}

Possui Doutorado em Biotecnologia pela Universidade Federal de Pelotas - UFPel (2012); Mestrado em Engenharia e Ciências de Alimentos pela Universidade Federal do Rio Grande - FURG (2008); Especialização em Ciência dos Alimentos pela Universidade Federal de Pelotas (2011) e Graduação em Engenharia de Alimentos pela Universidade Federal do Rio Grande - FURG (2006). Atualmente é professora na Universidade Federal do Pampa - UNIPAMPA - Campus Bagé, ministrando disciplinas para o Curso Superior de Engenharia de Alimentos.

\section{FRANKY SOEDIRLAN RESOSEMITO}

BSc em Quimica Industrial pela UFPB MSc em Ciência e Tecnologia de Alimentos pela UFPB DSc em Engenharia e Ciência de Alimentos pela UNESP

\section{GABRIELLA ARAUJO REBOUÇAS OLIVEIRA}

Atua principalmente nas áreas de Controle, Gestão de Qualidade e Segurança de Alimentos. Auditor Interno em HACCP Possui experiência como Coordenadora e Analista de Controle de Qualidade e na área de Microbiologia, com ênfase em Microbiologia de alimentos; Mestranda em Ciência e Tecnologia de Alimentos; MBA em Qualidade de Gestão de Processos; Graduação em Nutrição; Formação em ensino médio/técnico, com ênfase em Alimentos. 


\section{GLÁUCIA FREIBERGER}

Graduanda de Engenharia Química pela Universidade do Oeste de Santa Catarina (UNOESC). Atualmente bolsista do Programa de Bolsas do Fundo de Apoio à Manutenção e ao Desenvolvimento da Educação Superior (FUMDES) em parceria com empresa e voluntária em projetos de pesquisa científica e de inovação na área de produtos naturais e suas propriedades químicas e biológicas.

\section{GUILHERME AUGUSTO REBELATTO}

Graduando do curso de Engenharia Química pela Universidade do Oeste de Santa Catarina Unoesc, campus Joaçaba. Atualmente bolsista do Art. 170 do Programa de Bolsas Universitárias de Santa Catarina (UNIEDU), atuando como pesquisador e voluntário em projetos de pesquisas que envolvem as propriedades de produtos naturais.

\section{HELENA TEIXEIRA GODOY}

Possui graduação em Farmácia e Bioquímica pela Universidade de São Paulo (1981), mestrado e doutorado em Ciência de Alimentos pela Universidade Estadual de Campinas (1985 e 1993). É Professor Titular na Faculdade de Engenharia de Alimentos da Universidade Estadual de Campinas. É Membro do Comitê de Assessoramento da Área de Ciência e Tecnologia de Alimentos do Conselho Nacional de Desenvolvimento Científico e Tecnológico/CNPq. Recebeu prêmios/homenagens, destacando-se o Prêmio de Reconhecimento Acadêmico "Zeferino Vaz" em 2007 e os Prêmios Capes de Tese 2009 e o CAPES de Tese 2015 - Menção Honrosa. Publicou mais de 230 artigos em periódicos especializados. Ministrou várias palestras e cursos no Brasil e no exterior. Orienta trabalhos de Iniciação Científica, Conclusão de Curso na Área de Ciência e Tecnologia de Alimentos, dissertações de Mestrado e teses de Doutorado, além de supervisionar pós-doutorado. Coordenou e participou em mais de 70 projetos de pesquisa. Tem experiência na área de Ciência e Tecnologia de Alimentos, com ênfase em Análise de Alimentos. Os termos mais frequentes que caracterizam a produção científica são: desenvolvimento e validação de métodos analíticos, cromatografia, eletroforese capilar, espectrometria de massas, técnicas de preparação de amostra, ácido fólico, vitaminas, aditivos, compostos fenólicos, carotenoides, capacidade antioxidante, compostos voláteis, bioacessibilidade.

\section{HEMILY EDUARDA SANTOS LOPES}

Aluna do curso Técnica em Agroindústria do IFMA São Luís - Campus Maracanã

\section{JAQUELINE DA SILVA RUMÃO}

Técnica em Agroindústria pelo IFMA São Luís - Campus Maracanã Tecnóloga em Alimentos pelo IFMA São Luís - Campus Maracanã Mestranda em Ciência e Tecnologia de Alimentos pela Universidade de Passo Fundo

\section{JAQUELINE DE ARAÚJO BEZERRA}

Possui graduação em Química (2005), mestrado em Química com área de concentração em Química de Produtos Naturais (2008) e doutorado em Química com área de concentração em Química Orgânica (2014) pela Universidade Federal do Amazonas (UFAM). Atua principalmente em química de produtos naturais, estudo químico de PANC, caracterização química por Ressonância Magnética Nuclear e Espectrometria de Massas, ensaios de propriedades antioxidantes, enzimáticas e antimicrobianas, elaboração de fitoterápicos, tecnologia de alimentos, propriedade intelectual e inovação tecnológica. Atualmente é professora do Instituto Federal de Educação, Ciência e Tecnologia do Amazonas - IFAM/CMC e coordenadora da Central Analítica do IFAM-CMC. 


\section{JAQUELINE LIDORIO DE MATTIA}

Doutoranda no Programa de Bioenergia da FCT/UNL em Lisboa, possui mestrado em Educação pelo IF-Sul Pelotas e graduação em Educação Física. Professora assistente da Universidade Estadual do Rio Grande do Sul (Uergs). Investiga as possibilidades de uso dos resíduos agroindustriais para extração de compostos bioativos e bioprodutos para alimentação.

\section{JEFF OLIVEIRA SOARES}

Atualmente é discente do curso de Engenharia Química na Universidade Federal do Pampa (Campus Bagé). Participa de projetos no desenvolvimento de novos produtos a partir de resíduos provenientes da olivicultura. Participa como vice-diretor de marketing no diretório acadêmico de engenharia química. Além disso, possui experiência na área de análises físico-químicas de solo e participação no grupo GEPEAQ na síntese de derivados do 1,2,3-propanotriol a partir de reações de halogenação e oxidação . Também é cofundador da EPEQ Unipampa.

\section{JOÃO PEDRO GALLO DE OLIVEIRA}

Estudante de Nutrição pela Universidade Estadual Paulista Júlio de Mesquita Filho (UNESP)

\section{JOÃO TOMAZ SILVA BARCELLOS JUNIOR}

Tecnólogo em Gestão Ambiental e atualmente Técnico de Laboratório/ Área: Agroindústria junto a Universidade Federal do Pampa - Unipampa - Campus Bagé no qual desempenho as funções de planejamento, organização, monitoramento e avaliação do processo de aquisição, preparo e industrialização de produtos agropecuários de acordo com a legislação vigente; aplicando técnicas de "boas práticas de fabricação" nos processos agroindustriais e laboratoriais de controle de qualidade e auxilio nas atividades de ensino, pesquisa e extensão.

\section{JOSÉ CARLOS AZZOLINI}

Possui graduação em Química pela Universidade Federal de Santa Maria (1987) e mestrado em Engenharia de Produção pela Universidade Federal de Santa Catarina (2002). Atualmente é professor titular da Universidade do Oeste de Santa Catarina. Tem experiência na área de Química, com ênfase em Análise de Traços e Química Ambiental, atuando principalmente nos seguintes temas: águas industriais, parâmetros e tratamentos, poluição de águas superficiais e subterrâneas, lodo ativado, lançamento de efluente e dimensionamento de sistemas.

\section{JOSÉ TEIXEIRA FILHO}

Possui graduação pela Escola Politécnica da Universidade de São Paulo(1981), mestrado pela Escola Politécnica da Universidade de São Paulo(1989), mestrado em Hydrologie Science de l Eau Et Amenagement pela Université Montpellier 2 - Sciences et Techniques (1992), e doutorado em Gestão de Recursos Hídricos pela Université Montpellier 2 - Sciences et Techniques (1995). Atualmente é professor Livre-Docente da Universidade Estadual de Campinas e do Instituto Nacional de Pesquisas Espaciais. Recebeu vários prêmios, destacando-se pelas atividades na graduação da Faculdade de Engenharia Agrícola. Atua como orientador nos programas de PósGraduação em Engenharia Agrícola e no programa de Pós-Graduação em Geociências. Orienta trabalhos de Iniciação Científica, Conclusão de Curso na Área de Ciência e Tecnologia de Alimentos, dissertações de Mestrado e teses de Doutorado, além de supervisionar pós-doutorado. Coordenou e participou em vários projetos de pesquisa. Tem experiência na área de Engenharia Civil, com ênfase em Hidrologia Ciência da Água e Gestão. Atua principalmente nos seguintes temas: Hidrologia, Gestão dos Recursos Hídricos, modelagem hidrológica, modelagem de qualidade de água, modelos de previsão. 


\section{JOSIANE BETAT DA SILVA}

Possui graduação em Curso Superior de Tecnologia em Alimentos, Especialização em Tecnologia e Qualidade de Alimentos de Origem vegetal e mestrado em Engenharia de Alimentos. Atualmente é coordenadora e docente da Faculdade de Tecnologia SENAI Chapecó Santa Catarina. Tem experiência na área de Ciência e Tecnologia de Alimentos, com ênfase em Tecnologia de Produtos de Origem Vegetais e Biotecnologia.

\section{JÚLIA NASCIMENTO CALDAS}

Estudante do curso de Curso de Ciência e Tecnologia de Alimentos da Universidade Federal de Viçosa - Campus Rio Paranaíba

\section{JULIANA DE MELLO SILVA}

Professora na área de Engenharia de Alimentos da Universidade Estadual do Rio Grande do Sul UERGS. Ensino Médio Profissionalizante em Técnico em Química (2001). Graduação em Engenharia de Alimentos pela UERGS conveniada com UPF (2006). Especialista em Gestão Estratégica da Qualidade pela UCS (2008). Especialista em Controle e Qualidade de Alimentos pela UnC (2010). Mestrado em Engenharia de Alimentos pela URI-Erechim (2011). Doutorado em Engenharia e Ciência de Alimentos pela FURG (2016).

\section{JULIANA SILVEIRA DE QUADROS}

Atualmente é discente do curso de Engenharia de Alimentos na Universidade Federal do Pampa (Campus Bagé). Participa de projetos na área de cultivo de microalgas com aplicação em tratamento de efluentes e desenvolvimento de novos produtos a partir de resíduos provenientes da olivicultura. Participa como membro no grupo de óleos e gorduras da Unipampa. Além disso, possui experiência na área de análises físico-químicas de uva e vinho.

\section{KAELLY SIQUEIRA HORBE}

Acadêmica do curso de Ciência e Tecnologia dos Alimentos da Universidade Federal do Pampa, campus Itaqui

\section{KARLA JOSEANE PEREZ}

Doutora em Ciências Biológicas (Microbiologia) pela Universidade Federal de Minas Gerais/UFMG e Mestre em Microbiologia Agrícola e do Ambiente pela Universidade Federal do Rio Grande do Sul/UFRGS. Possui Especialização em Tecnologia e Controle de Qualidade de Alimentos pela UPF/RS e é Bióloga formada pela UNOESC/SC desde 2004. Atualmente é Professora Adjunta da área de Ciências Biológicas da Universidade Estadual do Rio Grande do Sul (UERGS), onde atua nos Cursos de Graduação em Engenharia de Bioprocessos e Biotecnologia e Ciência e Tecnologia de Alimentos além de compor o quadro permanente de docentes do Mestrado Profissional em Ciência e Tecnologia de Alimentos da Universidade.

\section{KELLEN SCHAAFF SOUTO}

Discente do curso de Nutrição da Universidade Federal de Santa Maria.

\section{LETÍCIA SANTA CATARINA}

Formada em engenharia química, pós graduada em segurança dos alimentos. Trabalha na Fullpack embalagens como gerente de qualidade. 


\section{LILIAN RAQUEL HICKERT}

Química Industrial formada pela UFSM, mestre em Microbiologia Agrícola e do Ambiente pela UFRGS, doutora e pós doutora em Engenharia Química pela UFRGS. Professora Adjunta da Universidade Estadual do Rio Grande do Sul.

\section{LILIANE FERNANDES DO NASCIMENTO}

Possui graduação em Ciências pela Universidade Estadual do Ceará (2003). Atualmente é professora universitária - CENTEC -FATEC SERTÃO CENTRAL. Tem experiência na área de Química, com ênfase em Química.

\section{LÚCIA ALLEMBRANDT DA SILVA RIES}

Possui graduação em Bacharelado de Química pela Universidade Federal do Rio Grande do Sul (1993), mestrado em Química pela Universidade Federal do Rio Grande do Sul (1996), doutorado em Ciência dos Materiais pela Universidade Federal do Rio Grande do Sul e Instituto Superior Técnico ? Lisboa/Portugal (2003) e pós-doutorados nas áreas de líquidos iônicos e eletrodeposição (2008) e células a combustível (2010). Desde 2010 é professora adjunta de Química na Universidade Estadual do Rio Grande do Sul.

\section{MARCOS BATISTA MACHADO}

Bacharel e Licenciado em Química pela Universidade Estadual Paulista - UNESP. Desenvolveu seu mestrado e doutorado em Química (Química Orgânica - Química dos Produtos Naturais) pela UNESP, com enfoque em isolamento e elucidação estrutural de compostos orgânicos provenientes de matrizes vegetais. Professor Associado do Departamento de Química do Instituto de Ciências Exatas da Universidade Federal do Amazonas - UFAM, campus de Manaus-AM. Coordenador do Laboratório Multiusuário e Multidisciplinar de Ressonância Magnética Nuclear (NMRLAB) da Central Analítica do Centro de Apoio Multiusuário da UFAM.

\section{MARI SILVIA RODRIGUES DE OLIVEIRA}

Possui graduação em Farmácia Modalidade Farmacêutico Bioquímico Tecnóloga em Alimentos pela Universidade Federal de Santa Maria (1993), mestrado em Ciência e Tecnologia dos Alimentos pela Universidade Federal de Santa Maria (1999) e doutorado pelo mesmo programa (2013). Atualmente é professor adjunto na Universidade Federal de Santa Maria-UFSM. Tem experiência na área de Ciência e Tecnologia de Alimentos, com ênfase em Tecnologia de Alimentos, atuando principalmente nos seguintes temas: desenvolvimento de alimentos, análises físico-químicas e microbiológicas de alimentos.

\section{MARIA LUCIENE MONTEIRO MENDES}

Graduação Tenológica em Alimentos - FATEC - Faculdade de Tecnologia CENTEC - Sertão Central. Perfil do Egresso: 0 Tecnólogo em Alimentos está apto à efetuar análises químicas, físico-químicas, microbiológicas e sensoriais em alimentos; controlar a qualidade da matéria prima, nos insumos e nos produtos; coordenar e classificação, a comercialização, o beneficiamento e o armazenamento de matérias primas para o consumo in natura e para a indústria; desenvolver novos produtos; gerenciar todos os processos nas indústrias de alimentos; atuar no serviço de inspeção sanitária, higienização e limpeza em alimentos; exercer a prática de orientação educacional-técnica em estabelecimentos de ensino profissionalizante, de extensão tecnológica e em instituições de pesquisas científicas e tecnológicas, cujo interesse estejam voltados para área de alimentos; implantar laboratórios de rotinas de controle de qualidade; identificar métodos apropriados para as análises e estabelecer planos de amostragem; aplicar a legislação em vigor em unidades processadoras de alimentos; prestar assistências tecnológicas, assessorias e consultorias na área de alimentos. Experiências profissionais: 07 (sete) anos como gerente administrativa em supermercado na área de alimentação; 13 (treze) anos caixa/vendedora em loja de calçados e confecção; 02 (dois) anos como microempreendedora individual - MEI; 300h (trezentas horas) de 
estágio supervisionado em panificadora, com o foco em treinamento e orientação de funcionários em boas práticas de fabricação de produtos panificados.

\section{MARIA TEREZA PASCHOAL DE MORAES}

Professora, Advogada, Intérprete de Libras, ex-Secretária de Educação de Ourinhos (SP), PósGraduada em Gestão Pública pelo CLP/Harvard/EUA e Líder RAPS e vencedora do Prêmio Espírito Público no Brasil - Educação em 2018. Atualmente é Secretária de Educação de Londrina (PR).

\section{MARIANE GARCIA ORQIS BARCELLOS}

Possui graduação em Ciências Biológicas (2007) e especialização em Biotecnologia e Meio Ambiente pela Universidade da Região da Campanha (2009). Atualmente atua como Técnica em Laboratório/Área:Biologia na Universidade Federal do Pampa (UNIPAMPA)- Campus Bagé

\section{MARISTELA SCHLEICHER SILVEIRA}

Doutoranda em Linguística - PUCRS. Mestre em Letras - URI-FW. Especialista em Informática na Educação -URI-FW. Licenciada em LETRAS - UNIJUI. Docente Faculdades SENAI - Santa Catarina. Interesse nos seguintes temas: Gênero Discursivo, Letramento, Leitura, comunicação; Elaboração de tarefas de leitura; Dialogia; Compreensão responsiva.

\section{MARTHA MENIN}

Graduou-se em Ciências Biológicas - Licenciatura pela Universidade Federal da Fronteira Sul Campus Realeza PR, no ano de 2017, e especializou-se em Educação Especial: área da Deficiência Visual pelo Instituto de Estudos Avançados (ESAP - Univale) no ano de 2018,. Realizou mestrado em Tecnologia de Processos Químicos e Bioquímicos, na Área da Biotecnologia, com enofque no uso de produtos naturais obtidos por plantas, pela UTFPR - Campus Pato Branco PR.

\section{MEIRE DE OLIVEIRA BARBOSA}

Graduação em Nutrição pela Universidade Federal de Viçosa (UFV) 2000. Mestre em Bioquímica em 2002, Doutora em Bioquímica em 2002 pela UFV. Docente da UFV-Campus Rio Paranaíba desde 2013.

\section{MILENA PADILHA}

Acadêmica do Curso Superior de Tecnologia de Alimentos (UFSM). Bolsista PIBITI (Programa Institucional de Bolsas de Iniciação Desen. Tec. e Inovação) no projeto de Obtenção de hidrolisados proteicos e colágeno a partir do resíduo do processamento de tilápia (Oreochromis niloticus) através de hidrólise enzimática assistida ou não por ultrassom.

\section{MIRIANE LUCAS AZEVEDO}

Possui Graduação em Bacharelado em Química de Alimentos pela Universidade Federal de Pelotas (2002), Especialização em Desenvolvimento Sustentável e Meio-ambiente pela Universidade da Região da Campanha (2004), Mestrado em Ciência e Tecnologia Agroindustrial pela Universidade Federal de Pelotas (2008), Doutorado em Ciência e Tecnologia Agroindustrial pela Universidade Federal de Pelotas (2011). Atualmente é Professora da Universidade Federal do Pampa - campus Bagé.

\section{PATRICIA DA SILVA MALHEIROS}

Possui graduação em Farmácia e Bioquímica - Tecnologia dos Alimentos pela Universidade Federal de Santa Maria (2004), mestrado em Ciência e Tecnologia dos Alimentos pela Universidade Federal do Rio Grande do Sul (2007), doutorado em Microbiologia Agrícola e do Ambiente pela 
Universidade Federal do Rio Grande do Sul (2011) e pós doutorado na área de Microbiologia de Alimentos pela Universidade de São Paulo (2014). Atualmente é professora adjunta no Instituto de Ciência e Tecnologia de Alimentos da Universidade Federal do Rio Grande do Sul (UFRGS).

\section{PAULA FERNANDA PINTO DA COSTA}

Engenheira Agrônoma, Mestre em Tecnologia dos Alimentos e Doutora em Ciência e tecnologia Agroindustrial. Professora adjunta na Universidade Federal do Pampa. Atua nos cursos de Agronomia, Ciência e Tecnologia de Alimentos, Nutrição e na especialização em Tecnologia de alimentos.

\section{RAFAELA ALEXIA RIBEIRO}

Estudante de graduação em Nutrição na Universidade Federal de Viçosa-campus Rio Paranaíba

\section{REBECA PRISCILA FLORA CATARINO}

Doutoranda em Ciência de Alimentos pela Universidade Estadual de Londrina (UEL). Possui mestrado em Ciência de Alimentos pela Universidade Estadual de Londrina (UEL). Cursou Tecnologia de Alimentos pela Universidade Tecnológica Federal do Paraná (2016). Possui formação técnica em Biotecnologia pelo SENAI/PR (2014). Atua nas áreas de "Desenvolvimento de produtos fermentados", "Fermentação e produtos fermentados" e "Aproveitamento de coprodutos agroindustriais e agrícolas". Estuda na linha de pesquisa "Inovação e desenvolvimento de produtos".

\section{RITA DE CASSIA SOARES}

Formada em Tecnologia de Alimentos e especialista em Gestão para segurança de Alimentos. Atua a 5 anos na área de qualidade e assuntos regulatórios. Atualmente é coordenadora de qualidade na empresa Nanovetores Tecnologia S.A, localizada na cidade de Florianópolis - SC.

\section{ROSA CRISTINA PRESTES DORNELLES}

Doutora em Engenharia de Alimentos pela Universidade Regional Integrada do Alto Uruguai e das Missões (URI) (2011), Mestre em Ciência e Tecnologia de Alimentos (2008) pela Universidade Estadual de Ponta Grossa (UEPG), MBA em Administração Estratégica e Gestão da Qualidade (2005) pelo Instituto Brasileiro de Pós-Graduação e Extensão (IBPEX) e graduada em Engenharia de Alimentos (2004) pela Universidade Estadual de Ponta Grossa (UEPG). Tem experiência na área de Ciência e Tecnologia de Alimentos com ênfase em Tecnologia de Produtos de Origem Animal, atuando principalmente nos seguintes temas: qualidade da carne e desenvolvimento de produtos cárneos funcionais.

\section{RÚBIA AGOSTINETO}

Graduanda de Engenharia Química pela Universidade do Oeste de Santa Catarina (UNOESC). Atualmente voluntária em projetos de pesquisa científica.

\section{SABRINA CREMONINI}

Formada no Curso Técnico em Alimentos no ano de 2012, Graduada em Tecnologia de Alimentos pela faculdade SENAI/SC no ano de 2017, Curso de Formação de Auditores Internos de Qualidade em Laboratórios segundo ABNT ISO 19011 pelo SENAI/DR/SC no ano de 2017, Pós-graduação Lato Sensu em Especialização Vigilância Sanitária, Controle de Qualidade e Inspeção em Indústria de Alimentos na Unochapecó/SC. (Em andamento 2020 - 2022). Técnica de laboratório no cargo Técnico Especialista. 


\section{SANDRINI SLONGO FORTUNA}

Engenheira de Alimentos, Mestra em Ciência e Tecnologia de Alimentos, especialista em Gestão Estratégica de Produção, trabalhou no desenvolvimento e análise da bioatividade de hidrolisados proteicos de buttermilk aliando o reaproveitamento de um resíduo industrial com novas alternativas de reutilização. Trabalhou com iniciação científica pela Secretaria do Desenvolvimento Econômico Ciência e Tecnologia do Rio Grande do Sul, com ênfase em Tecnologia de Alimentos, Processo de Separação por membranas e Desenvolvimento de produtos e processos.

\section{SAULO FABIANO AMÂNCIO-VIEIRA}

Doutor em Administração pela Universidade Nove de Julho (2010), Mestre em Administração pela Universidade Estadual de Maringá (2005) e graduado em Administração pela Universidade Estadual de Londrina (2002). Atualmente é professor Associado A do Departamento de Administração da Universidade Estadual de Londrina e do Programa de Mestrado em Administração - PPGA/UEL.

\section{SHEYLA MARIA BARRETO AMARAL}

Mestranda em Tecnologia de Alimentos no IFCE Campus Limoeiro do Norte (2019/2021). Tecnóloga em Alimentos pelo IFCE Campus Limoeiro do Norte (2016/2019). Bolsista de projeto de extensão MOSLIPRO E SILIEDU coordenado pela professora Karlucy Farias (2019/2020). Estagiária no Supermercado Nossa Família LTDA em Limoeiro do Norte (2019). Bolsista de projeto de Iniciação Científica (PIBIC), com a orientação da professora Séfura Moura (2018/2019). Bolsista de projeto de Iniciação em Desenvolvimento Tecnológico e Inovação CNPq (PIBITI), orientada pela professora Marlene Damaceno (2017/2018). Bolsista do laboratório de química básica do IFCE Campus Limoeiro do Norte (2017). Monitora voluntária da disciplina de química orgânica sob a orientação da professora Séfura Moura (2017).

\section{SILVIA REGINA MAGALHÃES COUTO GARCIA}

Professora Associada da Universidade Federal do Rio de Janeiro / Instituto de Nutrição Josué de Castro (INJC). Doutora em Ciências (Biotecnologia Vegetal) pela Universidade Federal do Rio de Janeiro com área de concentração em Segurança Alimentar (2008). Mestre em Ciência e Tecnologia de Alimentos pela Universidade Federal Rural do Rio de Janeiro (2002). Coordenadora do curso de graduação em Nutrição do INJC (2010 - 2014). Professora do Programa de Pós-graduação em Nutrição Clínica do Instituto de Nutrição Josué de Castro/UFRJ. Atua na área de Nutrição e Ciência e Tecnologia de Alimentos com ênfase no seguintes temas: desenvolvimento de produtos funcionais, alimentos orgânicos, agricultura familiar, alimentação coletiva, alimentos e produtos nutricionais com aplicação em nutrição clínica, gestão da qualidade e segurança alimentar e nutricional.

\section{SUSANA BERLEZE DE PELEGRINI}

Trabalha desde 2015 até o momento como nutricionista na Unidade de Educação Infantil Ipê Amarelo na Universidade Federal de Santa Maria/RS. Graduada em Nutrição pela Universidade Franciscana (2008). Possui Pós-Graduação em Nutrição Clínica Funcional. Mestrado em Ciência e Tecnologia dos Alimentos pela Universidade Federal de Santa Maria (2013).

\section{SUSLIN RAATZ THIEL}

Bacharel em Química de Alimentos (UFPel) (2015). Mestre em Ciência e Tecnologia dos Alimentos (UFSM) (2018), com estudos na linha de pesquisa de ciência da carne e produtos derivados, no projeto de aplicação de diferentes ingredientes na estabilidade de mortadela conservada a temperatura ambiente. Possui graduação no curso de Formação de Professores para a Educação Profissional (UFSM) (2018). Atualmente é doutoranda do Programa de Pós-Graduação em Ciência e Tecnologia dos Alimentos (UFSM), onde desenvolve trabalhos relacionados a atividade 
antimicrobiana e antioxidante de diferentes óleos essenciais e sua aplicação em filmes. Tem experiência em análises físico-químicas e microbiológicas.

\section{TICIANA LEITE COSTA}

Possui graduação em Tecnologia de Alimentos pelo Instituto Centro de Ensino Tecnológico Centec, mestrado em Engenharia Agrícola pela Universidade Federal de Campina Grande (2006). Tem experiência na área de Ciência e Tecnologia de Alimentos atuando principalmente nos seguintes temas: Qualidade e processamento de leites e carnes, conservação e reaproveitamento dos alimentos. Foi membro da Comissão própria de Avaliação (CPA) da Faculdade de Tecnologia Centec-Fatec Sertão Central no período de 2010 a 2013 e membro do Conselho Superior de Tecnologia de Alimentos no período de 2010 a 2012. Também membro do Conselho de curso-CST em Alimentos no período de 2014 a 2017 e Membro do Núcleo Docente Estruturante-NDE do curso de Tecnologia em Alimentos, no período de 2013 até dezembro de 2017. Participou da Comissão de elaboração de Projeto Pedagógico do curso técnico em Panificação e no de Pós graduação na em Saúde e Segurança Alimentar da Faculdade de Tecnologia Centec-Fatec Sertão Central. Foi Coordenadora do Eixo de Produção Alimentícia do curso superior de Tecnologia de Alimentos e Técnico em Panificação no período de maio de 2016 a Dezembro 2017. Atualmente professora e membro do colegiado do curso de Tecnologia em Alimentos, no Instituto Federal de Educação, Ciência e Tecnologia do Maranhão, IFMA-Campus Codó.

\section{VANDRÉ BARBOSA BRIÃO}

Graduado em Engenharia de Alimentos pela Fundação Universidade de Rio Grande (FURG), Mestre e Doutor em Engenharia Química pela Universidade Estadual de Maringá (UEM), Professor Titular da Universidade de Passo Fundo, bolsista Produtividade em Extensão Inovadora e Desenvolvimento Tecnológico do CNPq

\section{VERA LUCIA TIEKO SUGUIHIRO}

Professora Doutora, do Departamento de Serviço Social da Universidade Estadual de Londrina (UEL). Doutora e Mestre em Serviço Social pela Pontifícia Universidade Católica de São Paulo (PUC/SP). Graduada em Serviço Social pela Universidade Estadual de Londrina (UEL). Coordenadora de Área do Programa de Pós-graduação Especialização em Gestão Pública, parceria SETI/UEPG - Curso de Especialização em Gestão Pública. Pesquisadora na área da criança e adolescente; Conselhos de Direitos e Tutelares; Políticas Públicas e Orçamento Público. Presta assessoria e elaboração de projetos técnico e social na área de habitação, políticas urbanas e gestão pública. Pesquisadora Bolsa Produtividade - CNPq. Membro do corpo docente permanente do Programa de Mestrado e Doutorado Associado UEL/UEM em Arquitetura e Urbanismo.

\section{VERA MARIA RODRIGUES}

Engenheira química (UCS- RS), mestre e doutor em engenharia de alimentos (Unicamp- SP), na área de extração supercrítica de compostos naturais e óleos essências. Foi docente nas engenharia química e engenharia de alimentos e no PPGCTA (UPF-RS), com experiência na área de ciência e tecnologia de alimentos e desenvolvimento de produtos inovadores em lacticínios com baixo teor de lactose como iogurte sem lactose, atuou estudando compostos bioativos do funcionais em mirtilo e erva-mate, desenvolvendo bebidas e sorvete rico em compostos funcionais. Atualmente aposentada e atuando com consultoria.

\section{VILMAR ANTÔNIO BOFF}

Docente pesquisador com titulação de Doutorado em Desenvolvimento Regional. Atua na docência em cursos de Graduação e Pós Graduação - lato e stricto sensu. Atua em pesquisas com publicações vinculadas ao grupo de pesquisas ESADI - Estudos Setoriais em Administração, Desenvolvimento e Inovação. 


\section{VINÍCIUS DOS SANTOS RIBEIRO}

Acadêmico do curso de Engenharia de Bioprocessos e Biotecnologia da Universidade Estadual do Rio Grande do Sul e bolsista da Fundação de Amparo à Pesquisa do Estado do Rio Grande do Sul (FAPERGS).

\section{VIVIANE LOPES LEITE DA COSTA}

Graduada em Tecnologia em Alimentos pela Universidade Tecnológica Federal do Paraná (UTFPR), Campus Londrina. No momento atuo como colaboradora do "Programa de Atendimento à Sociedade Externa na Área de Produção, Análise, Ciência e Tecnologia de Alimentos", no Laboratório de Análise de Alimentos, do DCTA (CCA/UEL) e como colaboradora em projeto de extensão intitulado "Gestão da Qualidade de Alimentos: Extensão Inovadora na Merenda Escolar do Município de Londrina - PR", em parceria com a Prefeitura do Município de Londrina, onde aplicamos as ferramentas de gestão da qualidade na distribuição da merenda, nas escolas e creches de Londrina.

\section{WILMA APARECIDA SPINOSA}

Doutora em Ciência de Alimentos pela Universidade Estadual de Campinas (2002), Mestra em Ciência de Alimentos pela Universidade Estadual de Londrina (1996) e Graduada em Engenharia Química pela Universidade Estadual de Maringá (1981). Atualmente é Professora adjunta D do Departamento de Ciência e Tecnologia de Alimentos da Universidade Estadual de Londrina. Tem experiência na área de Engenharia Química, com ênfase em Ciência e Tecnologia de Alimentos, atuando principalmente nos seguintes temas: fermentação acética, produção de vinagres a partir de frutas, produção de biocelulose e levana por bactérias do ácido acético, desenvolvimento de produtos fermentados, estudo das propriedades de mel de abelhas-sem-ferrão, gestão da qualidade de alimentos, microbiologia industrial, potabilidade de água, produção, controle e estocagem de alimentos. 
